\title{
Instream Biological Assessment of NPDES Point Source Discharges at the Savannah River Site, 1997-1998
}

by

W. L. Specht

Westinghouse Savannah River Company

Savannah River Site

Aiken, South Carolina 29808

M. H. Paller

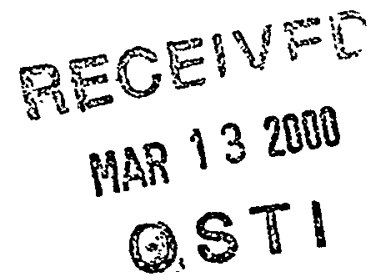

DOE Contract No. DE-AC09-96SR18500

This paper was prepared in connection with work done under the above contract number with the U.S. Department of Energy. By acceptance of this paper, the publisher and/or recipient acknowledges the U.S. Government's right to retain a nonexclusive, royalty-free license in and to any copyright covering this paper, along with the right to reproduce and to authorize others to reproduce all or part of the copyrighted paper. 


\section{DISCLAIMER}

Portions of this document may be illegible in electronic image products. Images are produced from the best available original document. 


\section{DISCLAIMER}

This report was prepared as an account of work sponsored by an agency of the United States Government. Neither the United States Government nor any agency thereof, nor any of their employees, makes any warranty, express or implied, or assumes any legal liability or responsibility for the accuracy, completeness, or usefulness of any information, apparatus, product or process disclosed, or represents that its use would not infringe privately owned rights. Reference herein to any specific commercial product, process or service by trade name, trademark, manufacturer, or otherwise does not necessarily constitute or imply its endorsement, recommendation, or favoring by the United States Government or any agency thereof. The views and opinions of authors expressed herein do not necessarily state or reflect those of the United States Government or any agency thereof.

This report has been reproduced directly from the best available copy:

Available for sale to the public, in paper, from: U.S. Department of Commerce, National Technical Information Service, 5285 Port Royal Road, Springfield, VA 22161

phone: (800) 553-6847

fax: (703) 605-6900

email: orders@ntis.fedworld.gov

online ordering: http://www.ntis.gov/ordering.htm

Available electronically at http://www.doe.gov/bridge

Available for a processing fee to U.S. Department of Energy and its contractors, in paper, from: U.S. Department of Energy, Office of Scientific and Technical Information, P.O. Box 62, Oak Ridge, TN 37831-0062

phone: (865)576-8401

fax: (865)576-5728

email: reports@adonis.osti.gov 


\title{
INSTREAM BIOLOGICAL ASSESSMENT OF NPDES POINT SOURCE DISCHARGES AT THE SAVANNAH RIVER SITE, 1997-1998
}

\author{
by \\ WINONA L. SPECHT and \\ MICHAEL H. PALLER \\ SAVANNAH RIVER TECHNOLOGY CENTER
}

Approved by:

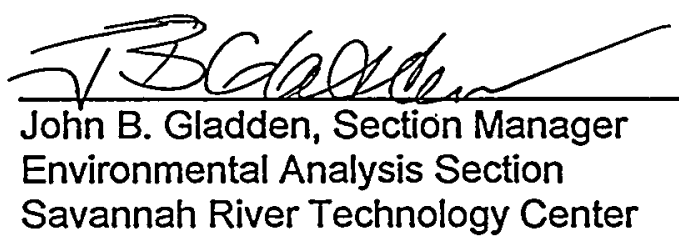

Publication Date: October 1998

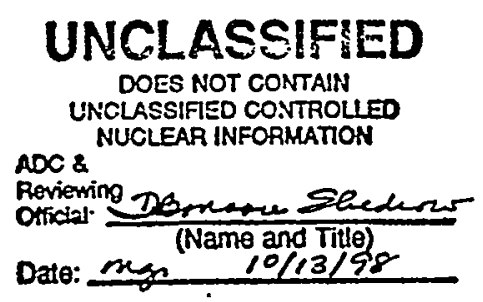

WESTINGHOUSE SAVANNAH RIVER COMPANY

SAVANNAH RIVER SITE

AIKEN, SC 29808

\footnotetext{
THIS DOCUMENT WAS PREPARED IN CONNECTION WITH WORK UNDER U.S. DEPARTMENT OF ENERGY CONTRACT DE-AC09-88SR18035. By acceptance of this paper, the publisher and/or recipient acknowledges the U.S. Government's right to retain a nonexclusive, royalty-free license in and to any copyright covering this paper, along with the right to reproduce and to authorize others to reproduce all or any part of the copyrighted paper.
} 


\section{TABLE OF CONTENTS}

\section{Page}

Executive Summary 1

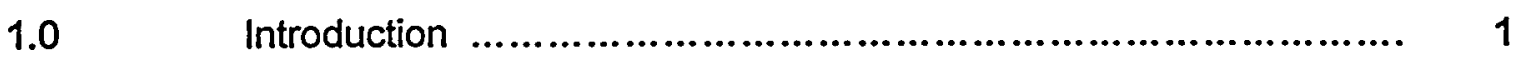

2.0 Description of Streams, Effluents, and Sampling Locations .......... 1

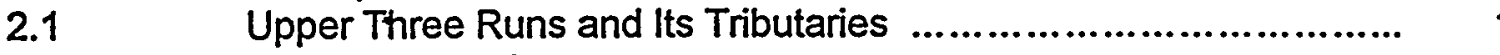

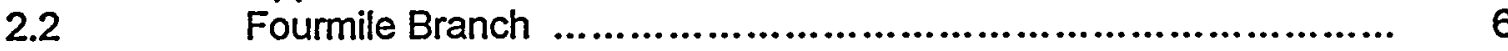

2.3 Pen Branch/Indian Grave Branch ....................................... 6

2.4 Steel Creek/Meyers Branch ............................................. 7

2.5 Other Water Bodies/NPDES Discharges ............................. 7

Methods $\quad$ M................................................................ 8

3.1 Habitat Assessment/Water Chemistry ................................. 8

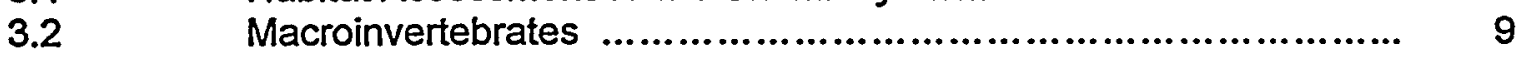

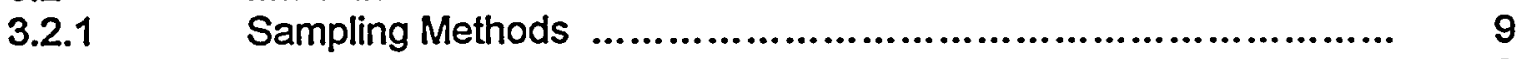

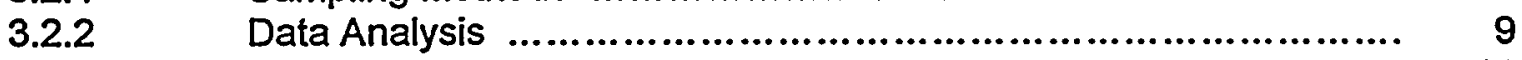

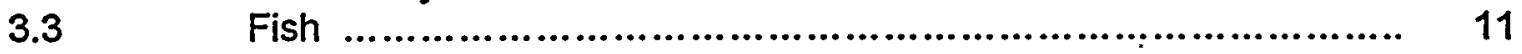

3.3.1 Sampling Methods ...................................................... 11

B.3.2 Data Analysis ......................................................... 12

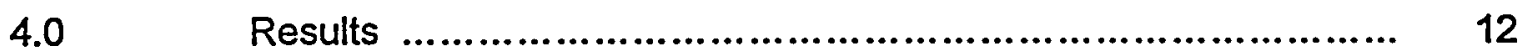

4.1 Upper Three Runs Watershed ........................................ 12

4.1.1 Macroinvertebrates ................................................... 12

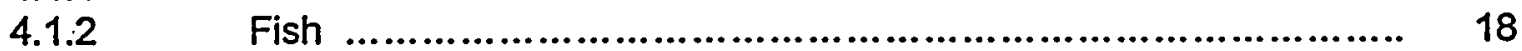

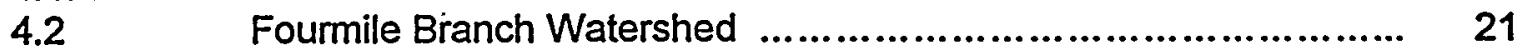

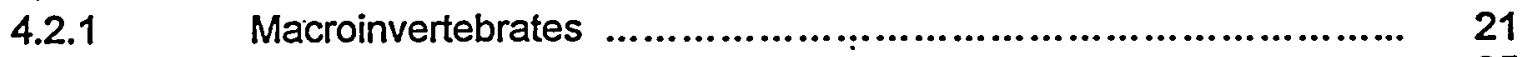

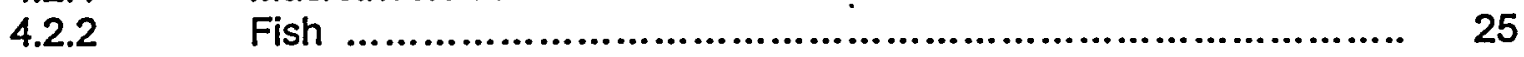

4.3 Pen Branch Watershed ................................................. 26

4.3.1 Macroinvertebrates ........................................................ 26

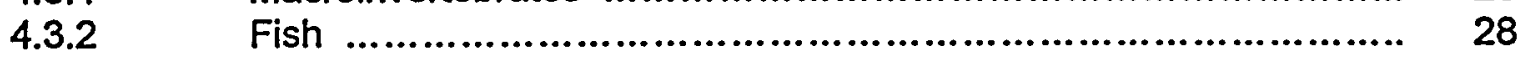

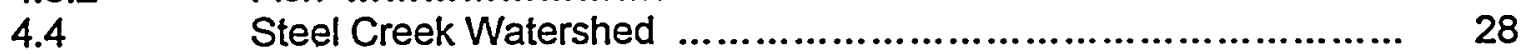

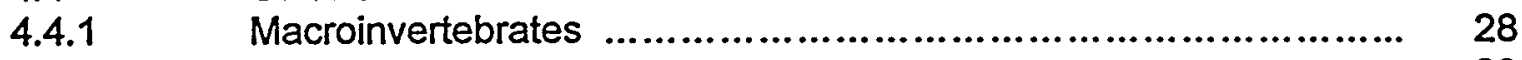

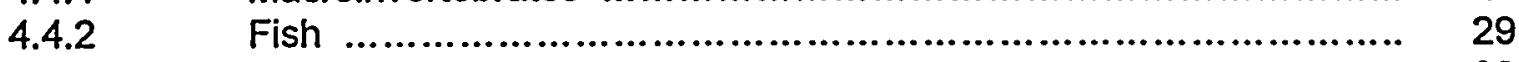

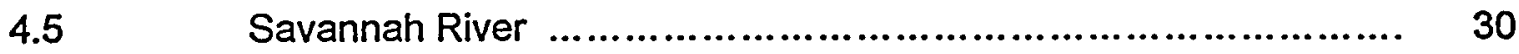

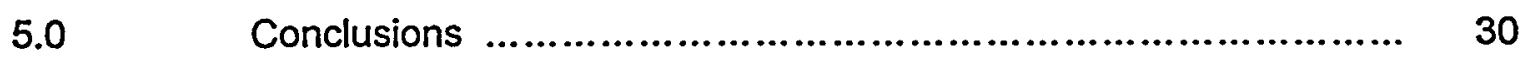

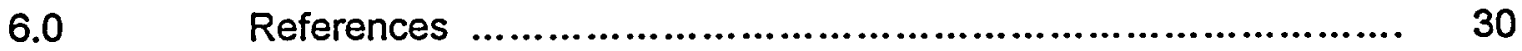


Appendix Tables

Appendix A Statistical Results for Macroinvertebrate Data Appendix $B \quad$ Macroinvertebrate Data

Appendix B-1 Species List, Hester-Dendy Multiplate Samplers

Appendix B-2 Species List, Qualitative Sampling of Natural Substrates

Appendix B-3 Macroinvertebrate Data, by Replicate

Appendix B-4 Percent Composition by Major Taxonomic Group

Appendix B-5 Functional Feeding Group Analysis

Appendix B-6 Summary of Biological Indices for Macroinvertebrate Data

Appendix B-7 Biological Parameter Results and Water Quality Ratings

Appendix C Fish Assemblage Data 
List of Tables

Page

Table 1 Sampling Locations for NPDES Biological Monitoring ............... 2

Table 2 SRS NPDES Outfalls, Receiving Streams and Contributing

Waste Streams

Table 3 Metrics for Macroinvertebrate Multiplate and Qualitative Data .....

Table 4 Metrics and scoring criteria used in the Index of Biotic Integrity (IBI), modified by Paller et al (1995). The modified IBI is calculated by summing the scores for the individual metrics.

Table 5 Summary of Macroinvertebrate Data, Upper Three Runs and Tributaries, November 1997

Table 6 Dominant Taxa Collected from Hester-Dendy Multiplate

Samplers, November 1997

Table $7 \quad I B I$ values from stream sites receiving NPDES discharges $(\eta)$ and stream sites unaffected by NPDES discharges $(N)$

Table 8 Means for habitat variables. Variables were measured at nine transects at each sample station except for Four Mile Creek Rd. C, Upper Three Runs Tyler Bridge, and Upper Three Runs Rd.

A.2 where variables were measured at six transects

Table 9 Summary of Macroinvertebrate Data, Fourmile Branch, November 1997

Table 10 Physical/Chemical Data for SRS Stream Sampling Locations, December 8, 1997

Table 11 Summary of Macroinvertebrate Data, Pen Branch and Steel Creek, November 1997

\section{List of Figures}

Figure 1 Map of the Savannah River Site showing sampling stations for fish and macroinvertebrates

Figure 2 Hester-Dendy Multiplate Sampler

Figure $3 \quad \mathrm{IBI}$ values at 29 undisturbed stream sites located on and near the SRS. Samples are described more fully in Paller and Dyer 1997 


\section{Executive Summary}

Fish and macroinvertebrates were collected at unimpacted reference locations and downstream of NPDES discharges in Upper Three Runs and its tributaries, Fourmile Branch, Pen Branch/Indian Grave Branch, and Steel Creek to determine if the receiving streams have been impacted by the NPDES discharges. The results of the macroinvertebrate and fish surveys conducted during this study were generally in close agreement. Both indicated that most SRS streams were characterized by high biotic integrity and unaffected by SRS NPDES discharges. A prominent exception was Crouch Branch which, as indicated by both the macroinvertebrate and fish data, was significantly degraded. Further research will be required to determine whether this degradation was related to NPDES discharges, habitat, or other factors. Degradation was also observed in upper Fourmile Branch and upper Steel Creek, but in these cases was probably related to factors other than NPDES discharges. Factors that may have depressed biotic integrity in these streams reaches included previous thermal impacts, reservoir impoundment related effects, possible construction impacts, and naturally occurring habitat factors.

\subsection{Introduction}

The Savannah River Site (SRS) currently has 33 permitted NPDES outfalls that that have been permitted by the South Carolina Department of Health and Environmental Control (SCDHEC) to discharge to SRS streams and the Savannah River. In order to determine the cumulative impacts of these discharges to the receiving streams, a study plan was developed to perform in-stream assessments of the fish assemblages, macroinvertebrate assemblages, and habitats of the receiving streams. These studies were designed to detect biological impacts due to point source discharges. Sampling was conducted between November 1997 and July 1998. Sampling will be repeated in 2000. A total of 18 locations were sampled (Table 1, Figure 1). Sampling locations for fish and macroinvertebrates were generally the same. However, different locations were sampled for fish (Road A-2) and macroinvertebrates (Road C) in the lower portion of Upper Three Runs, to avoid interference with ongoing fisheries studies at Road C. Also, fish were sampled in Fourmile Branch at Road 4 rather than at Road $F$ because the stream at Road $F$ was too narrow and shallow to support many fish. Sampling locations and parameters are detailed in Sections 2 and 3 of this report. In general, sampling locations were selected that would permit comparisons upstream and downstream of NPDES outfalls. In instances where this approach was not feasible because effluents discharge into the headwaters of a stream, appropriate unimpacted reference were used for comparison purposes.

\subsection{Descriptions of Streams, Effluents, and Sampling Locations.}

\subsection{Upper Three Runs and Its Tributaries}

Upper Three Runs is a fifth order stream that originates approximately $12 \mathrm{~km}$ north of the northern boundary of SRS and flows generally south, entering the Savannah River at River Mile (RM) 157.2 (Figure 1). Tributaries of Upper Three Runs that enter the stream along its flow path from north to south through the Savannah River Site include Tinker Creek, with its major tributaries of Mill Creek, Reedy Branch and McQueen 
Table 1. Sampling Locations for NPDES Biological Monitoring

\section{LOCATION}

Upper Three Runs Watershed

Upper Three Runs, Road 8-1

(macroinvertebrates only)

Upper Three Runs, Tyler Bridge (fish

only)

Upper Three Runs, Road C

(macroinvertebrates only)

Upper Three Runs, near Road A-2

(fish only)

Tims Branch near Road 2

Mill Creek, Monroe Owens Road

McQueen Branch near Z-Area

Crouch Branch, Road 4

Fourmile Branch Watershed

Fourmile Branch, Road F

(macroinvertebrates only)

Fourmile Branch Road 4 (fish only)

Fourmile Branch, Road C

Fourmile Branch, Road A-7

Fourmile Branch, Road A

\section{Pen Branch Watershed}

Pen Branch, Road C

Pen Branch, Road B

Indian Grave Br. near cooling tower

Pen Branch, Road A

Steel Creek Watershed

Steel Creek, near Road C

Meyers Branch, Old Dunbarton Rd.
SITE\# STATUS

3 Reference

17 Reference

2 Downstream from all discharges

18 Downstream from all discharges

1 Downstream from all discharges

4 Reference

5 Downstream from all discharges

6 Downstream from all discharges

7 Reference

19 Downstream from H-Area

8 Downstream from $F / H$ Areas

9 Downstream from all discharges but

C-Area

16 Downstream from all discharges

10 Reference

11 Reference

12 Downstream from all discharges

13 Downstream from all discharges

14 Downstream from P-Area; upstream from L Lake

15 Reference

Branch; Crouch Branch; and Tims Branch. With the exception of McQueen Branch, which enters Tinker Creek just before its confluence with Upper Three Runs, Tinker Creek and its tributaries have been largely uninfluenced by SRS activities, and these streams receive no NPDES discharges.

McQueen Branch originates just east of $\mathrm{H}$-Area and flows generally northwest for about $4 \mathrm{~km}$ to its confluence with Tinker Creek. As shown in Table 2, McQueen Branch receives the discharge from the $\mathrm{H}-07$ and S-04 NPDES discharges. These discharges 


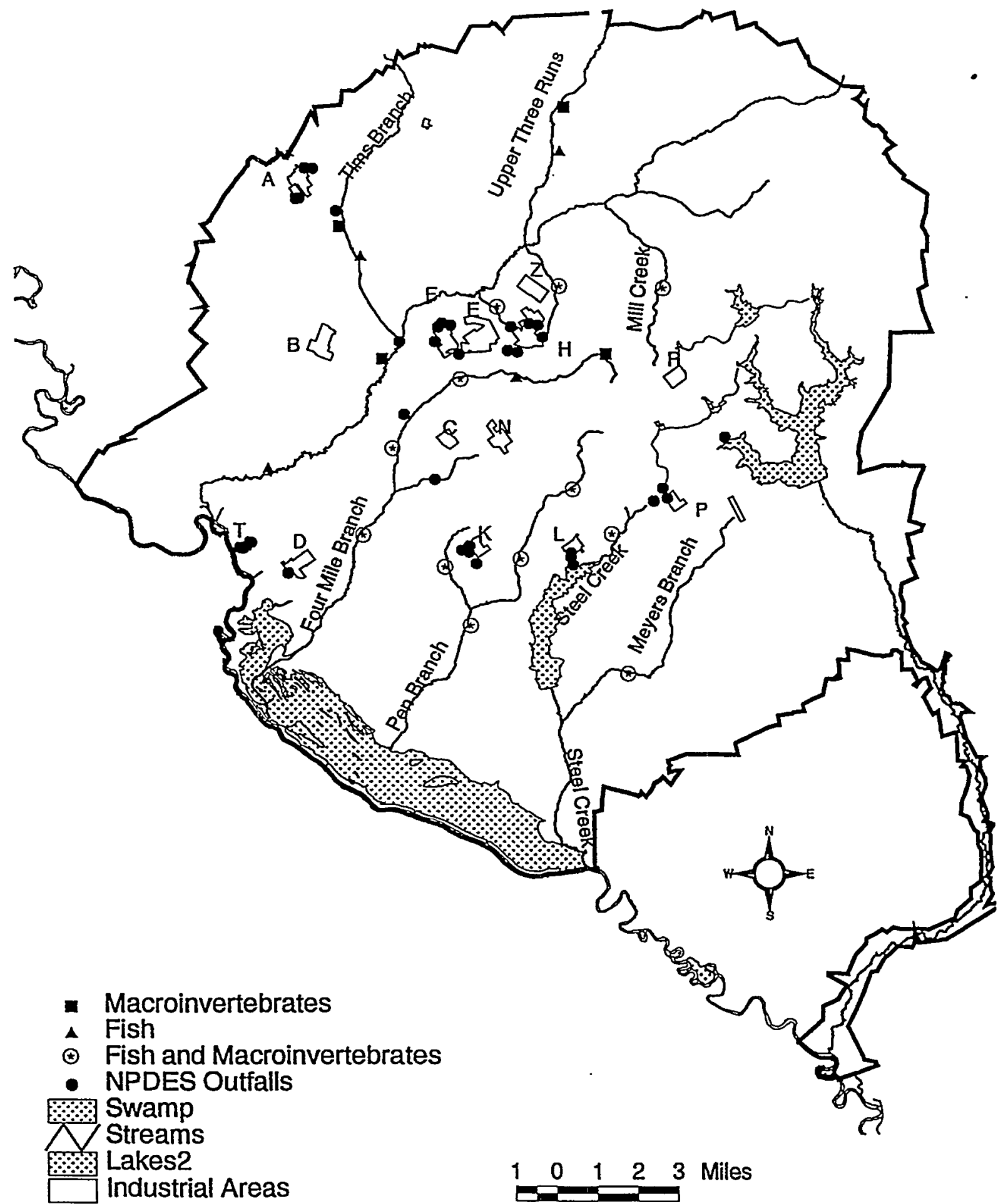

Figure 1. Map of the Savannah River site showing sampling stations for fish and macroinvertebrates 


\section{Table 2. SRS NPDES Outfalls, Receiving Streams and Contributing Waste Streams} \begin{tabular}{l} 
Outfall Receiving Stream \\
\hline Upper Three Runs Watershed
\end{tabular}

A-01 Tims Branch

$\begin{array}{ll}\text { A-01A } & \text { Tims Branch via A-01 } \\ \text { A-11 } & \text { Tims Branch } \\ & \\ \text { M-04 } & \text { Tims Branch via A-11 } \\ \text { M-05 } & \text { Tims Branch via A-11 } \\ \text { F-01 } & \text { UTR tributary } \\ \text { F-02 } & \text { UTR tributary } \\ \text { F-03 } & \text { UTR tributary } \\ \text { F-05 } & \text { UTR tributary } \\ \text { H-02 } & \text { Crouch Branch } \\ \text { H-04 } & \text { Crouch Branch } \\ \text { H-07 } & \text { McQueen Branch } \\ \text { S-04 } & \text { McQueen Br. tributary } \\ \text { H-16 } & \text { UTR }\end{array}$

Beaver Dam Creek Watershed D-01A BDC via D-01

\section{Fourmile Branch Watershed}

F-08 FMB tributary

G-10 FMB

H-08 FMB tributary

$\mathrm{H}-12 \quad \mathrm{FMB}$ tributary

Pen Branch Watershed

K-06 IGB tributary

K-10 IBG

$\mathrm{K}-12 \quad$ IGB via K-18

$\mathrm{K}-18 \quad$ IGB

Steel Creek Watershed

\begin{tabular}{ll}
\hline L-07 & L-Lake \\
L-07A & L-Lake via L-07 \\
L-08 & L-Lake
\end{tabular}

Lower Three Runs Watershed PP-01 Par Pond

\section{Savannah River}

$\begin{array}{ll}\text { X-04 SR swamp } \\ X-08 & \text { SR }\end{array}$

$X-08 A \quad S R$ via $X-08$

$X-08 B \quad$ SR via $X-08$

$X-08 C \quad S R$ via $X-08$

$X-19 \quad S R$
Inputs

cooling water, lab drains, air stripper effluent from $A-01 A$, steam \& AC condensates air stripper

floor drains, condensate. Well flush water, cooling water, treated wastewater from $M-04$ and $M-05$

LETF process wastewater air stripper effluent cooling water, blowdown, storm water . cooling water, blowdown, storm water cooling water, steam condensate, blowdown, process water cooling water, steam condensate, storm water cooling water, storm water cooling water, storm water, CIF wastewater, steam condensate cooling water, blowdown, storm water neutralization waste water, cooling water, storm water F/H ETF

sanitary effluent

cooling water, steam condensate, process wastewater, laundry effluent, water tank overflow, storm water sanitary cooling water, steam condensate, ash basin, lab drains, storm water

cooling water, ITP neutralized flush water, storm water

cooling water, blowdown, powerhouse waste, storm water Infrequent diversion from $\mathrm{K}-18$

sanitary

186 basins, cooling water, sanitary from $K-12$

sanitary from L-07A, 186 basins, floor drains, storm water sanitary cooling water, storm water

rinse water and backwash from drinking water filter system

welding quench sink water, steam condensate, storm water cooling water, sanitary from $X-08 \mathrm{~A}$, process water, TNX ETF effluent from $X-08 B$, air stripper effluent from $X-08 \mathrm{C}$ sanitary TNX ETF effluent air stripper effluent treated groundwater

UTR- Upper Three Runs; BDC- Beaver Dam Creek; FMB- Fourmile Branch; IGB- Indian Grave Branch; SR-Savannah River 
consist primarily of neutralized wastewater, cooling water and storm water. McQueen Branch was also impacted by scouring and siltation during construction of the DWPF during the 1980's and early 1990's. Crouch Branch is a small tributary of Upper Three Runs that originates just northwest of $\mathrm{H}$-Area and flows northwest for about $2 \mathrm{~km}$ to Upper Three Runs.

Crouch Branch receives NPDES discharges from the $\mathrm{H}-02$ and $\mathrm{H}-04$ outfalls, which primarily contain cooling water, steam condensate, Consolidated Incinerator Facility (CIF) treated wastewater, and stormwater. Crouch Branch was also impacted by scouring and siltation during construction of the DWPF.

Tims Branch originates near A Area and flows southeast for about $8 \mathrm{~km}$, entering Upper Three Runs just upstream from the Road $\mathrm{C}$ bridge. Tims Branch is the receiving stream for 5 NPDES outfalls (A-01, A-01A, A-11, M-04, and M-05), and a large portion of the flow in Tims Branch is comprised of NPDES effluents. These effluents include cooling water condensates, and water from lab drains, floor drains, two air strippers, an effluent treatment facility, and various other sources (see Table 2). Tims Branch also received inputs of metals from $M$ Area during its early years of operation, and some of the metals (primarily aluminum, nickel, and uranium) are present in elevated concentrations in the depositional areas of Tims Branch.

Four NPDES discharges from F-Area (F-01, F-02, F-03 and F-05), consisting mainly of noncontact cooling water, blowdown, and steam condensate are discharged to flow paths that lead to Upper Three Runs. The H-16 outfall, which is the effluent from the F/H Effluent Treatment Facility (ETF) is the only NPDES outfall that discharges directly into Upper Three Runs. $\mathrm{H}-16$ enters the stream just downstream from the Road C bridge. All NPDES effluents enter the portion of Upper Three Runs between its confluence with Tinker Creek and just downstream from the Road C bridge. In all, 14 NPDES outfalls enter the Upper Three Runs watershed (see Table 2).

Upstream reference locations in the Upper Three Runs were the Road 8-1 bridge (macroinvertebrates only) and Tyler Bridge (fish only). Fish were sampled at Tyler Bridge instead of Road 8-1 because fish are routinely collected at Road 8-1 by the Environmental Monitoring Section (EMS) of WSRC, which may alter the community structure of the fish community at this location. Sampling locations located downstream from SRS discharges include the Road C bridge (macroinvertebrates only), which is just downstream from the most-downstream NPDES discharge $(\mathrm{H}-16)$ as well as just downstream from Tims Branch, the most downstream tributary that contains NPDES discharges (Figure 1, Table 2) and near Road A-2 (fish only). Fish were sampled near Road A-2 instead of Road C because EMS also collects fish at Road C. Also sampled were McQueen Branch behind Z-Area, Crouch Branch at Road 4, and Tims Branch near Road 2. Upstream reference locations for these streams were not available, since effluents discharge into the headwaters of all three of these tributaries. However, Mill Creek, an unimpacted tributary of Upper Three Runs, was sampled as a reference location for the tributaries of Upper Three Runs. 


\subsection{Fourmile Branch}

Fourmile Branch is a third order stream that originates southeast of $\mathrm{H}$-Area and flows generally west and southwest for about $25 \mathrm{~km}$, entering the Savannah River at RM 150.6, just across the river from the Vogtle Nuclear Power Plant. The first five $\mathrm{km}$ of the stream receive no NPDES discharges. Four NPDES outfalls (F-08, G-10, H-08 and $\mathrm{H}-12)$ discharge to Fourmile Branch and all of the discharges are to the portion of the stream located between just upstream from Road 4 to approximately $1 \mathrm{~km}$ upstream from Road A-7. NPDES discharges to the stream include cooling water, ash basin overflows, treated sanitary waste from the new central sanitary treatment plant, storm water and other miscellaneous sources (see Table 2). Fourmile Branch also receives inputs from the $\mathrm{F} / \mathrm{H}$ seepline, which is primarily encompassed by the area between Roads 4 and $C-4$. Shallow groundwater from the old $F / H$ seepage basins and the old Burial Ground outcrops near this section of Fourmile Branch. This water contains elevated levels of tritium, as well as above-background concentrations of some metals and other contaminants. The portion of Fourmile Branch from approximately $0.5 \mathrm{~km}$ downstream from Road 3 to the Savannah River was subject to very high temperatures and flows until 1984, when the operation of $C$ Reactor was discontinued. The habitat of the post-thermal streams still differs substantially from the habitat in streams that were not exposed to high temperatures and flows, primarily with respect to canopy cover, the composition of stream substrate, in-stream structure (size and amount of woody debris, etc.), and riparian vegetation. These habitat differences have had lasting influence on the biotic communities of the post-thermal streams.

Sampling locations in Fourmile Branch included Road $F$, which is upstream from all SRS discharges; Road C, which is downstream from the H-Area discharges; Road A-7 which is downstream from the F-Area outfall and sanitary treatment plant, but upstream of where the C-Area outfalls previously entered Fourmile Branch, and Road A, which is downstream from all SRS discharges, and is a post-thermal location.

\subsection{Pen Branch/Indian Grave Branch}

Pen Branch is a third order stream that originates near the intersection of Roads $F$ and 6 and flows generally southwest for approximately $17 \mathrm{~km}$ to the Savannah River swamp, exiting the swamp to the Savannah River via Steel Creek. Indian Grave Branch is a small tributary of Pen Branch that is located just west of $\mathrm{KArea}$. It is about $4 \mathrm{~km}$ long and flows generally south, merging with Pen Branch approximately one $\mathrm{km}$ upstream of Road A. Four NPDES discharges (K-06, K-10, K-12, and K-18) enter Indian Grave Branch from K Area (Table 2); no effluents discharge directly to Pen Branch. The discharges to Indian Grave Branch consist primarily of cooling water, powerhouse waste, storm water, and a small quantity of treated sanitary effluent. Indian Grave Branch was also the receiving stream for the thermal discharge from $\mathrm{K}$ Reactor, which operated until 1988. Like Fourmile Branch, Indian Grave Branch and the portion of Pen Branch that was impacted by thermal discharge have very different habitat than the non-thermal streams. These habitat differences need to be considered when interpreting biological data from the post-thermal streams.

Sampling locations in Pen Branch and Indian Grave Branch included Pen Branch at Roads $C$ and $B$, which are both upstream from all SRS discharges, Pen Branch at 
Road $A$, which is downstream from Indian Grave Branch and all SRS discharges, and Indian Grave Branch near the cooling tower, which is downstream of all existing K-Area NPDES discharges to this tributary. Because effluents discharge into the headwaters of the stream, no upstream reference location could be sampled in Indian Grave Branch.

\subsection{Steel Creek/Meyers Branch}

Steel Creek is a third order stream that originates west of $P$ Reactor and flows south for about $18 \mathrm{~km}$, entering the Savannah River at RM 141.6. A portion of Steel Creek wás impounded in 1985 to form L Lake, a 1000 acre cooling reservoir. The lake has not received thermal discharges since 1988. Meyers Branch is a major tributary of Steel Creek that originates east of $P$ Reactor and flows generally southwest for about $12 \mathrm{~km}$, merging with Steel Creek approximately one $\mathrm{km}$ downstream from the L-Lake dam. Steel Creek is the receiving stream for three NPDES outfalls (L-07, L-07A, and L-08; Table 2). The discharges consist primarily of cooling water, building drains, stormwater, and a small volume of treated sanitary effluent. Meyers Branch has been largely unimpacted by SRS activities. In the past, small quantities of effluent were discharged into the swamp near the headwaters of Meyers Branch, but the stream presently receives no NPDES discharges.

Sampling locations in Steel Creek and Meyers Branch included Steel Creek near Road $\mathrm{C}$, which is downstream from the P-Area discharges into Steel Creek and Meyers Branch at old Dunbarton Road. Two NPDES outfalls from L Area discharge to L Lake, which is located downstream from the sampling location in Steel Creek. However, the volume of the discharges is small and would be diluted by the entire volume of $L$ Lake prior to discharging into lower Steel Creek. Lower Steel Creek was not sampled because previous studies indicated that the stream community was influenced by the lentic community of $L$ Lake, and it would be impossible to distinguish between possible outfall impacts and the greater influence of $L$ Lake discharges into the stream. Meyers Branch at old Dunbarton Road was sampled as a reference location for Steel Creek and some of the other sampling locations.

\subsection{Other Water Bodies/NPDES Discharges}

A number of NPDES outfalls discharge to other locations on the SRS (Table 2). Outfall D-01A consists of treated sanitary discharge that is discharged to the D-01 outfall. Outfall PP-01 consists of a very small amount of backwash water from a drinking water filter system at the Par Pond laboratory that discharges to Par Pond. However, neither Beaver Dam Creek nor Par Pond/Lower Three Runs were included in the permit condition that requires biological sampling. Six outfalls from TNX discharge indirectly to the Savannah River. Due to the small volume of effluent in relation to the large dilution factor provided by the river, and because previous studies have not detected any impact from SRS operations to the Savannah River, studies in the Savannah River were not included in this study, but a discussion of previous biological studies conducted on the Savannah River is presented in Section 4.5. 


\subsection{Methods}

\subsection{Habitat Evaluation/Water Chemistry}

Physical habitat data were collected from each fish assemblage sample site to assist in the interpretation of the biological data. These data were collected from transects running across the stream perpendicular to the direction of water flow. Except at the sample sites in Upper Three Runs, there were three transects evenly spaced within each $50 \mathrm{~m}$ section for a total of nine habitat transects per site. Because of the difficulty in obtaining habitat data from Upper Three Runs, which was comparatively deep and wide, there were only two evenly spaced habitat transects per site in this stream. The following habitat data were collected at each transect:

1) Stream width (distance from waters edge to waters edge).

2) Depth of the stream (nearest $0.01 \mathrm{~m}$ ) at a minimum of approximately $20 \%, 40 \%$, $60 \%$, and $80 \%$ of the distance from the left bank to the right bank.

3) Current velocity $(\mathrm{cm} / \mathrm{s})$ at each point where depth was measured. Where depth equaled or exceeded $0.6 \mathrm{~m}$, two current velocity measurements were taken, one at 0.2 times the depth and one at. 0.8 times the depth. Where the depth was less than $0.6 \mathrm{~m}$, only one measurement was taken at 0.6 times the distance from the surface.

4) Predominant substrate types (mud, sand, gravel, rocks) in the vicinity of the transect (i.e., $3 \mathrm{~m}$ upstream from the transect and $3 \mathrm{~m}$ downstream from the transect). Visual estimate.

5) Bottom area (nearest $5 \%$ ) covered by debris (detritus and leaves). Visual estimate.

6) Number of logs (i.e., recumbent wood in excess of $6 \mathrm{~cm}$ in diameter) in the vicinity of the transect.

7) Number of stumps in the vicinity of the transect.

8) Number of cypress knees in the vicinity of the transect.

9) Bottom area (nearest $5 \%$ ) covered by fibrous root systems. Visual estimate.

10) Bottom area (nearest $5 \%$ ) covered by brush piles/log jams. Visual estimate.

11) Aquatic macrophyte cover (nearest $5 \%$ ) and the predominant types (submerged, emergent, floating) in the vicinity of the transect. Visual estimate.

12) Amount of stream surface (nearest $5 \%$ ) overhung by low growing riparian vegetation (e.g. shrubs, grasses, and small trees) in the vicinity of the transect. Visual estimate.

13) Canopy cover (nearest 5\%) and the predominant canopy types (cypress/tupelo forest, hardwood forest, pine forest) in the vicinity of the transect. Visual estimate. 14) Bank erosion on a scale of zero (none) to severe (three). Visual Estimate.

To maintain consistency and facilitate comparisons among sample reaches, all habitat variables requiring visual estimation (i.e., $4,5,8,9,10,11$, and 12) were recorded by the same person.

Physical and chemical data collected in conjunction with the biological data included water temperature, dissolved oxygen, $\mathrm{pH}$ and specific conductance. These data were collected by ETT Environmental, Greenville, SC (SCDHEC Certification \# 23104) at the time that the multiplate samples were retrieved. Temperature was measured to the nearest degree using a mercury thermometer, dissolved oxygen was measured using a YSI Model 51B dissolved oxygen meter, pH was measured using a Fisher Model 1001 
pH meter, and specific conductance was measured using a VWR Model 604 conductivity meter.

\subsection{Macroinvertebrates}

\subsubsection{Sampling Methods}

Sampling and identification of macroinvertebrates for this sampling program were performed by ETT Environmental (SCDHEC Certification \# 23104). At each sampling location, five replicate Hester-Dendy multiplate samplers (Figure 2), each having a surface area of $0.179 \mathrm{~m}^{2}$ were deployed and allowed to colonize for 28 days. The samplers were retrieved and returned to the laboratory for processing. In the laboratory, the samplers were disassembled and organisms gently removed from the plates using a soft brush or a stream of water from a wash bottle. Organisms were preserved in $70 \%$ ethanol until identified to the lowest practical taxon (usually genus).

Although multiplate samplers provide a uniform substrate for macroinvertebrate sampling, the species composition and relative abundance of macroinvertebrate assemblages collected from multiplate samplers differ from natural substrates. Some taxa are over-represented on multiplate samplers, while other taxa are underrepresented or completely absent. In order to perform a thorough assessment of the macroinvertebrate community at each sampling site, qualitative sampling of natural substrates was also performed. At the time that the multiplates were retrieved, sampling of natural substrates (leaf packs, snags, root mats, woody debris, etc.) present at the sampling site was performed for one man hour per sampling station, and macroinvertebrates present on the substrates were collected, preserved, and returned to the laboratory for identification.

\subsubsection{Data Analysis}

Descriptive Parameters - The multiplate data was analyzed for the parameters listed in Table 3. In addition, the total number of taxa collected from each location was tallied for the quantitative and qualitative data combined.

Statistical Analyses - Although data were collected from six locations that are upstream from all SRS discharges, data from two of the locations were not included in the statistical analyses. Upper Three Runs at Road 8-1 was excluded because Upper Three Runs is a much larger stream (fifth order) than the other streams that were sampled (mostly second and third order). However, this location was used as a comparison for the downstream location on Upper Three Runs (Road C). Data from Fourmile Branch at Road F were excluded because data from this location indicated obvious perturbation, probably due to low dissolved oxygen concentrations. Multiplate data from the four remaining reference stations were compared to stations that are downstream from SRS NPDES outfalls. Because the data were not normally distributed and/or did not have homogenous variances, nonparametric tests were performed, using the Kruskal-Wallis one way ANOVA on ranks. Parameters that were compared included total number of taxa, total number of EPT taxa, density of organisms, and NCBI. Details of the statistical analyses are presented in Appendix A. 


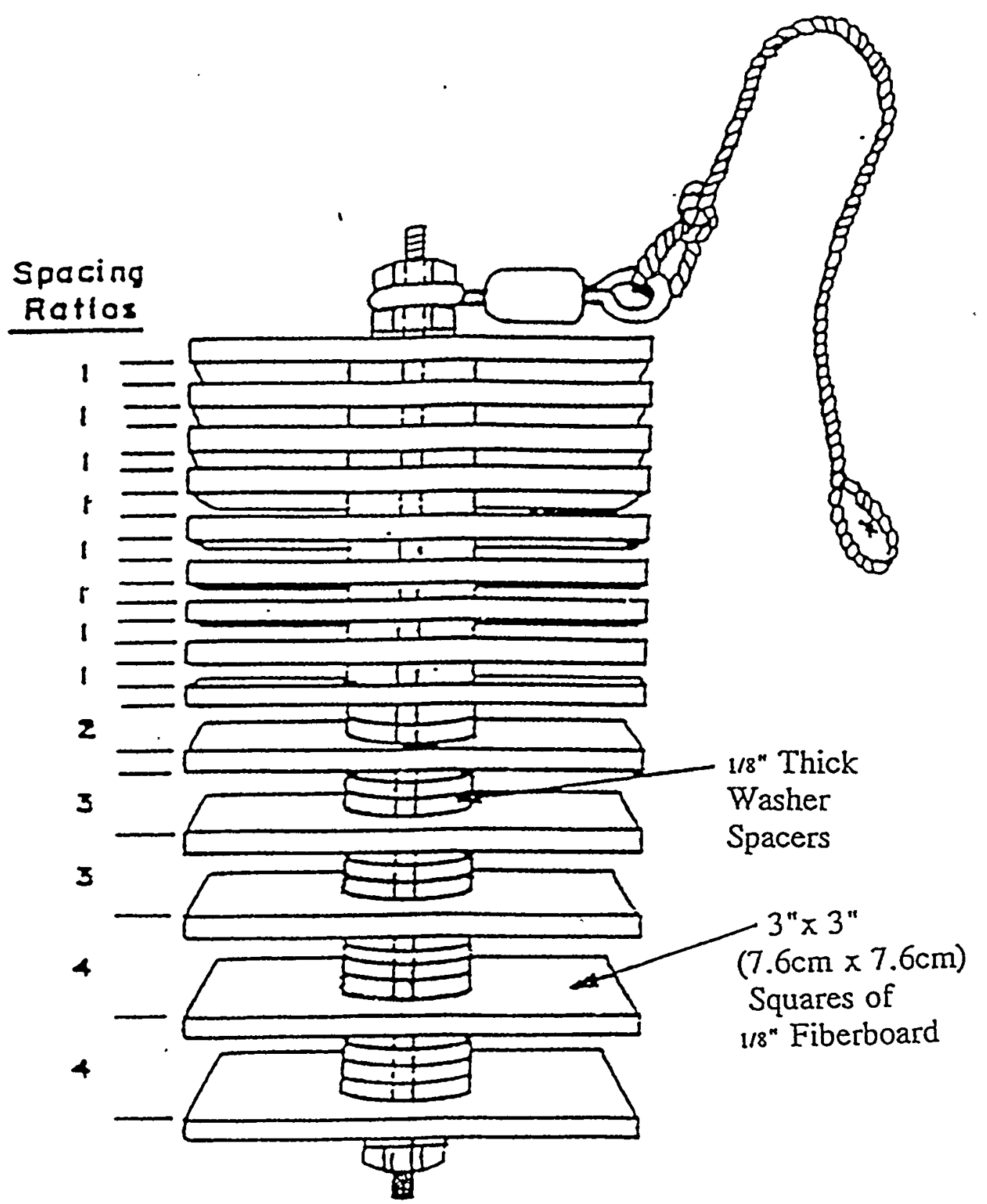

Figure 2. Hester-Dendy Multiplate Sampler 
Table 3. Metrics for Macroinvertebrate Multiplate and Qualitative Data

Quantitative (Multiplate) Data

Total number of taxa

Mean Number of taxa/sampler

Mean density of organisms (number $/ \mathrm{m}^{2}$ )

Biomass ( $g$ ash-free dry weight $/ \mathrm{m}^{2}$ )

Total number of EPT (Ephemeroptera, Plecoptera, Trichoptera) taxa

Relative abundance (\%) of major taxonomic groups

Relative abundance (\%) of functional feeding groups

Relative abundance (\%) of functional feeding group biomass

Listing of dominant taxa ( $>5 \%$ abundance)

North Carolina Biotic Index (NCBI; Lenat, 1993)

\section{Qualitative Data}

Total number of taxa

Total number of EPT taxa

North Carolina Biotic Index (NCBI)

\subsection{Fish}

\subsubsection{Sampling Methods}

Fish assemblages were sampled at 16 sites. Five of these (one in Mill Creek, one in Meyers Branch, two in Pen Branch, and one in Upper Three Runs) were located upstream from SRS NPDES outfalls (Figure 1). The other sites were located in areas potentially impacted by SRS NPDES discharges. With the exception of the uppermost portion of Four Mile Creek, all stream reaches sampled for macroinvertebrates were also sampled for fish; although, in some cases, the exact locations sampled differed somewhat (Figure 1). Reasons for differences between fish and macroinvertebrate sampling locations will be discussed in greater detail later in this report.

Three $50 \mathrm{~m}$ stream segments were electrofished at each sample site. All sites except for those in Upper Three Runs were sampled with a Coffelt backpack electrofisher powered by a generator, a Smith-Root backpack electrofisher powered by a battery, or a Smith-Root backpack electrofisher powered by a generator. A single pass was made through each $50 \mathrm{~m}$ segment at each site while moving upstream. All microhabitats were carefully sampled in an effort to obtain as many species and individuals as possible by collecting them with dip nets after they had been stunned by DC current. At relatively narrow sites (under $4-5 \mathrm{~m}$ ) we used one backpack electrofisher and a two or three person crew. At wider sites, two back pack electrofishers and two crews were used, with a crew covering each bank as both moved upstream simultaneously. To sample Upper Three Runs, the widest (up to $20 \mathrm{~m}$ in the sample areas) and deepest stream (up to $2.1 \mathrm{~m}$ ), a $4.5 \mathrm{~m}$ boat with a boat mounted generator and a Smith-Root 
electrofisher was used. Each bank was sampled separately in Upper Three Runs using the previously described protocol. All fish were identified to species and released.

\subsubsection{Data Analysis}

Fish assemblage data were analyzed using the Index of Biotic Integrity (IBI). The IBI is a bioassessment method used to assess the biotic integrity of streams. Biotic integrity is the ability of a stream to support a self sustaining biological community and ecological processes typical of undisturbed, natural conditions (Angermeier and Karr 1994). The $|\mathrm{B}|$ uses fish assemblage data to assess biotic integrity. It is composed of a number of community, population, and organism level variables that are ecologically important and sensitive to environmental disturbances of various types. These variables are measured at assessment sites, compared to those in a range of similar but undisturbed benchmark streams, and the results summarized in a single number that reflects the extent to which the assessment site resembles the benchmark. The IBI has been endorsed by the USEPA (Plafkin et al. 1989) and has been adapted for use throughout the United States and in a number of foreign countries. It has been modified for use in SRS streams where it accurately discriminated undisturbed sites from sites affected by physical habitat alterations and chemical pollution (Paller et al. 1996).

The IBI was calculated using methods presented in Paller et al. 1996 and Paller and Dyer 1997. IBI metrics and scoring criteria for the metrics are listed in Table 4.

This methodology adjusts for differences in stream size and sample area making it possible to directly compare $|\mathrm{B}|$ values from streams and sample areas of different size. The highest $\mathrm{IBI}$ value that can be obtained using the methods of Paller et al. (1996) is 50. The IBI was calculated for each $50 \mathrm{~m}$ segment at each location. The statistical significance of differences between the average IBI at the undisturbed sample sites and the average $\mid \mathrm{BI}$ at the sample receiving NPDES discharges was assessed with the Kruskal-Wallis test $(P \leq 0.05)$. In addition, the average $|\mathrm{B}|$ at each sample site was compared to $|\mathrm{B}|$ values at 29 undisturbed locations sampled during previous sampling programs. This data (hereafter referred to as historical data) is described more fully in Paller and Dyer (1997).

\subsection{Results}

\subsection{Upper Three Runs Watershed}

\subsubsection{Macroinvertebrates}

As discussed in Section 2.1, sampling was performed at two locations in Upper Three Runs: Road 8-1, which is upstream from all NPDES discharges to the stream and just downstream from Road C, which is downstream from all NPDES discharges and tributaries that receive discharges. With respect to most of the parameters that were measured, the Road $\mathrm{C}$ site appears to support a more diverse and higher quality macroinvertebrate community than the Road 8-1 site. The total number of taxa collected, for qualitative and quantitative sampling combined was 81 at Road C and 51 at Road 8-1 (Table 5). A total of 16 EPT taxa were collected from multiplate samplers at Road $C_{1}$ as compared to 15 at Road 8-1. However, the NC biotic index for 
Table 4. Metrics and scoring criteria used in the Index of Biotic Integrity (IBI) as modified by Paller et al (1995). The modified IBI is calculated by summing the scores for the individual metrics.

\begin{tabular}{|c|c|c|c|}
\hline \multirow{2}{*}{ Metrics } & \multicolumn{2}{|c|}{ Scoring criteria } & \multirow[b]{2}{*}{5} \\
\hline & 1 & 3 & \\
\hline \multicolumn{4}{|l|}{ Species richness } \\
\hline Adjusted number species ${ }^{a}$ & $<70$ & $70-90$ & $>90$ \\
\hline Adjusted number cyprinid & $<55$ & $55-80$ & $>80$ \\
\hline \multicolumn{4}{|l|}{ species $^{a}$} \\
\hline Adjusted number piscivorous & $<65$ & $65-85$ & $>85$ \\
\hline \multicolumn{4}{|l|}{ species $^{a}$} \\
\hline Number darter species & 0 & $1-2$ & $\geq 3$ \\
\hline Number madtom species & 0 & 1 & $\geq 2$ \\
\hline Number intolerant species & 0 & 1 & $\geq 2$ \\
\hline \multicolumn{4}{|l|}{ Species composition } \\
\hline Percent tolerant species & $>15$ & $5-15$ & $<5$ \\
\hline Percent sunfish species & $>45$ & $25-45$ & $<25$ \\
\hline \multicolumn{4}{|l|}{ Trophic composition } \\
\hline Percent insectivorous cyprinids & $<20$ & $20-35$ & $>35$ \\
\hline $\begin{array}{l}\text { Percent generalized } \\
\text { insectivores }\end{array}$ & $>75$ & $50-75$ & $<50$ \\
\hline \multicolumn{4}{|l|}{ Fish abundance (Number/100 $\mathrm{m}^{2}$ ) } \\
\hline Stream orders $1-3, \geq 4$ passes & $<25$ & & $\geq 25$ \\
\hline Stream orders $1-3,1$ pass & $<10$ & & $\geq 10$ \\
\hline Stream order $4, \geq 4$ passes & $<5$ & & $\geq 5$ \\
\hline Stream order $4, \overline{1}$ pass & & $<2$ & \\
\hline \multicolumn{4}{|l|}{ Fish condition } \\
\hline Percent with disease or & $>5$ & $>2-5$ & $0-2$ \\
\hline
\end{tabular}

a Species number expressed as a percentage of the number of species expected in an unimpacted stream after adjusting for the effects of sample area, stream order, and sampling effort (Paller et al. 1995). Maximum percentage equals 100.

the multiplate data was lower (better) at Road 8-1 (3.70) than at Road C (4.84).

Dominant groups of taxa at both locations included dipteran midges, Trichoptera, Plecoptera, and Ephemeroptera (Table 6). The mean density of macroinvertebrates on multiplate samplers was higher at Road C (232 organisms $\left./ \mathrm{m}^{2}\right)$ than at Road 8-1 (93.3 organisms $/ \mathrm{m}^{2}$ ), but biomass (ash-free dry weight) was similar at both sites, equaling $0.2590 \mathrm{~g} / \mathrm{m}^{2}$ at Road $8-1$ and $0.2582 \mathrm{~g} / \mathrm{m}^{2}$ at Road C. With respect to functional feeding groups, shredders were abundant at both locations $(32.3 \%$ at Road $C ; 35.7 \%$ at Road 8-1), but collector-gatherers were more abundant at Road C (40\%) than at Road 8-1, while collector-filterers were more abundant at Road 8-1 (32.7\%) than at Road C (11\%). An abundance of collector-filterers is often an indication of organic 
Table 5. Summary of Macroinvertebrate Data, Upper Three Runs and Tributaries, November 1997

\begin{tabular}{|c|c|c|c|c|c|c|}
\hline$\cdot$ & 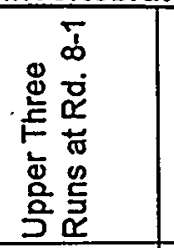 & 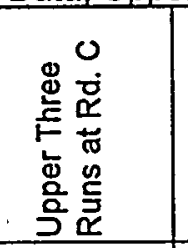 & 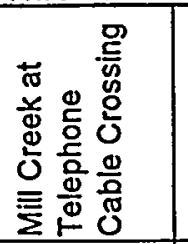 & 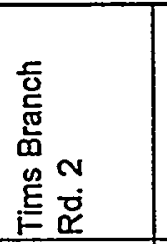 & 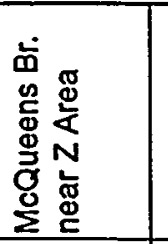 & 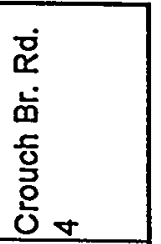 \\
\hline & Site 3 & Site 2 & Site 4 & Site 1 & Site 5 & Site 6 \\
\hline \multicolumn{7}{|c|}{ MULTIPLATE (QUANTITATIVE DATA) } \\
\hline Total \# species & 27 & 37 & 20 & 17 & 11 & 5 \\
\hline Mean \# species/replicate & 5.4 & 7.4 & 4.0 & 3.4 & 2.2 & 1.0 \\
\hline EPT Index & 15 & 16 & 9 & 3 & 5 & 0 \\
\hline Density (organisms $/ \mathrm{m}^{2}$ ) & 93.3 & 232.0 & 112.0 & 73.3 & 53.3 & 8.9 \\
\hline Total biomass $\left(\mathrm{g} / \mathrm{m}^{2}\right)$ & 0.2590 & 0.2582 & 0.0518 & 1.0685 & 0.0317 & 0.0006 \\
\hline NC Biotic Index & 3.70 & 4.84 & 4.87 & 6.72 & 5.18 & 8.88 \\
\hline \multicolumn{7}{|l|}{$\begin{array}{l}\text { Relative Abundance of Major } \\
\text { Taxonomic Groups }\end{array}$} \\
\hline Annelida (worms) & 0.0 & 0.5 & 0.0 & 25.8 & 0.0 & 0.0 \\
\hline Mollusca (clams, snails) & 0.0 & 0.0 & 0.0 & 0.0 & 0.0 & 0.0 \\
\hline Crustacea & 0.0 & 0.0 & 0.0 & 0.0 & 0.0 & 0.0 \\
\hline Ephemeroptera & 10.7 & 11.0 & 55.4 & 1.5 & 64.6 & 0.0 \\
\hline Plecoptera & 34.5 & 18.2 & 21.8 & 0.0 & 8.3 & 0.0 \\
\hline Trichoptera & 23.8 & 9.6 & 5.0 & 9.1 & 10.4 & 0.0 \\
\hline Odonata & 1.2 & 0.0 & 1.0 & 0.0 & 0.0 & 25.0 \\
\hline Hemiptera & & 0.0 & 0.0 & 0.0 & 0.0 & 0.0 \\
\hline Coleoptera & 2.4 & 1.9 & 1.0 & 0.0 & 0.0 & 0.0 \\
\hline Diptera (excluding midges) & 8.3 & 1.0 & 0.0 & 22.7 & 0.0 & 0.0 \\
\hline Diptera (midges) & 16.7 & 57.9 & 12.9 & 39.4 & 12.5 & 75.0 \\
\hline Chironomini & 3.6 & 6.2 & 8.9 & 1.5 & 0.0 & 62.5 \\
\hline Orthocladiinae & 3.6 & 45.9 & 2.0 & 12.1 & 12.5 & 0.0 \\
\hline Tanypodinae & 1.2 & 0.0 & 2.0 & 10.6 & 0.0 & 12.5 \\
\hline Tanytarsini & 8.3 & 5.7 & 0.0 & 15.2 & 0.0 & 0.0 \\
\hline Other & 2.4 & 0.0 & 2.9 & 1.5 & 4.2 & 0.0 \\
\hline \multicolumn{7}{|l|}{$\begin{array}{l}\text { Relative Abundance of } \\
\text { Functional Feeding Groups }\end{array}$} \\
\hline Collector-gatherers & .10 .7 & 40.0 & 36.6 & 37.1 & 52.1 & 25.0 \\
\hline Collector-filterers & 32.7 & 11.0 & 0.0 & 45.5 & $\cdot 2.1$ & 0.0 \\
\hline Predators & 15.5 & 11.5 & 12.9 & 12.1 & 6.3 & 37.5 \\
\hline Scrapers & 5.4 & 6.0 & 28.2 & 0.8 & 32.3 & 0.0 \\
\hline Shredders & 35.7 & 32.3 & 24.3 & 4.5 & 7.3 & 37.5 \\
\hline \multicolumn{7}{|l|}{$\begin{array}{l}\text { Relative Abundance of } \\
\text { Functional Feeding Group } \\
\text { Biomass }\end{array}$} \\
\hline Collector-gatherers & 0.3 & 7.8 & 22.6 & 0.3 & 26.4 & $<0.1$ \\
\hline Collector-filterers & 3.3 & 4.9 & $<0.1$ & 0.8 & 2.0 & $<0.1$ \\
\hline Predators & 94.5 & 54.3 & 50.8 & 98.9 & 42.3 & 100.0 \\
\hline Scrapers & 1.6 & 6.8 & 22.6 & $<0.1$ & 26.4 & $<0.1$ \\
\hline Shredders & 0.3 & 26.2 & 4.1 & $<0.1$ & 2.9 & $<0.1$ \\
\hline \multicolumn{7}{|c|}{ QUALITATIVE DATA } \\
\hline total \# species & 41 & 61 & 39 & 33 & 33 & 3 \\
\hline EPT Index & 18 & 20 & 9 & 3 & 12 & 0 \\
\hline NC Biotic Index & 4.76 & 4.45 & 5.62 & 6.37 & 5.39 & 7.6 \\
\hline \multicolumn{7}{|c|}{ ITATIVE AND QUANTITATIVE DATA COMBINED } \\
\hline total \# species & 51 & 81 & 50 & 41 & 38 & 8 \\
\hline
\end{tabular}


Table 6. Dominant Taxa Collected from Hester-Dendy Multiplate Samplers, Savannah River Site, November 1997

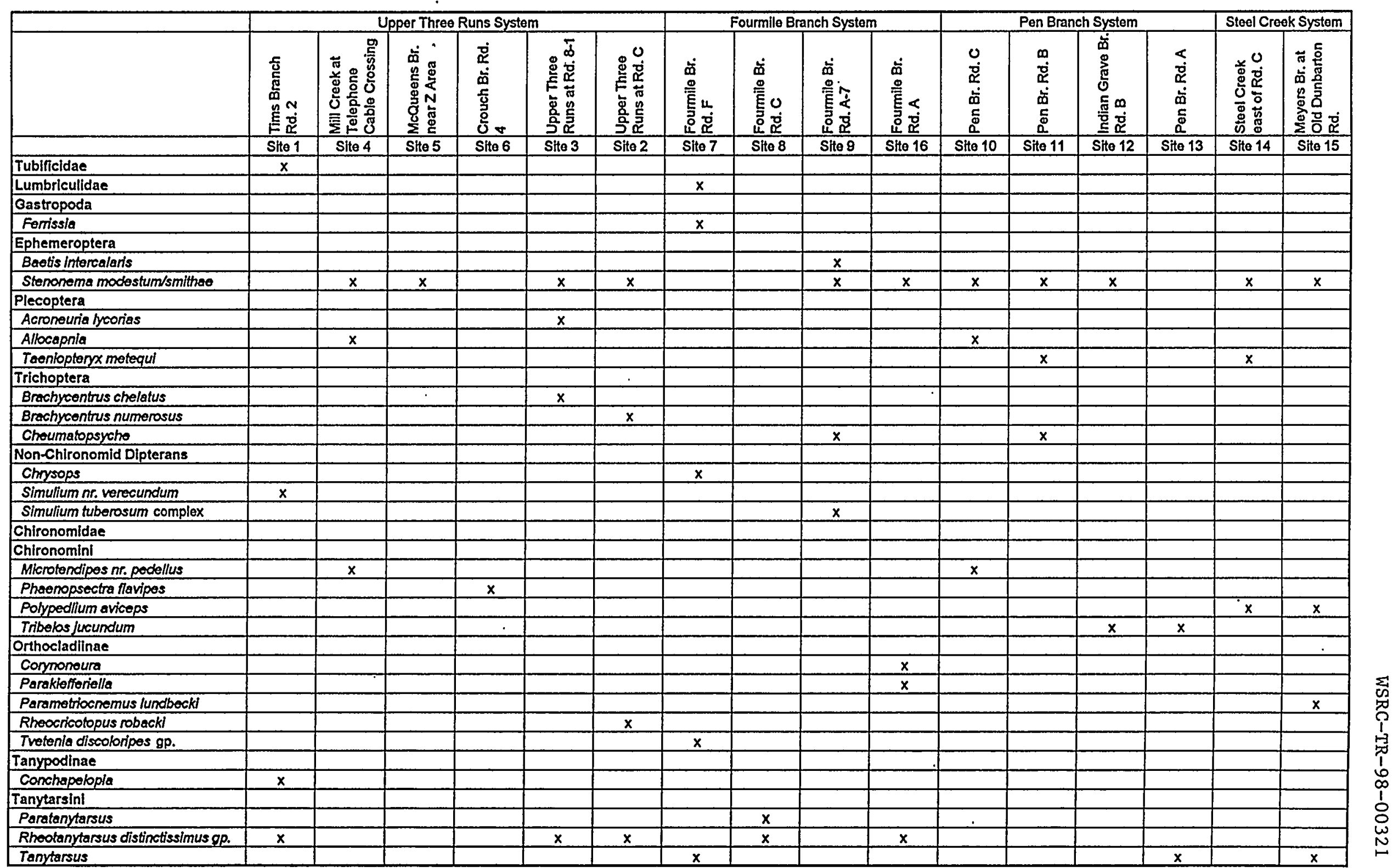


enrichment or of pooled water, both of which can result in higher concentrations of phytoplankton, which along with other fine particulate organic matter, are used as food by collector-filterers. Upper Three Runs does not receive any inputs of treated sanitary discharges north of the SRS, but increased development in the off-site headwaters of the stream may be resulting in increased nutrient loading. It is also possible that there are beaver dams upstream of Road 8-1 that are forming small impoundments on the stream. The qualitative data from natural substrates also indicated that both species richness and EPT richness were higher at Road C (61 and 20, respectively) than at Road 8-1 (41 and 18, respectively;' Table 5). Unlike the multiplate data, the qualitative data also indicated that Road $C$ had a lower biotic index value (4.45) than Road 8-1 (4.76), which further substantiates that the macroinvertebrate community at Road $C$ is somewhat more diverse than the community at Road 8-1.

Tributaries of Upper Three Runs that were sampled include McQueen Branch, Crouch Branch, Tims Branch, and Mill Creek. Of these only Mill Creek receives no NPDES discharges. Mill Creek is a high quality stream, and has a drainage area that is fairly similar to the size of the Tims Branch watershed, but is considerably larger than the watersheds of McQueen Branch and Crouch Branch. Since taxonomic richness generally increases with stream size, McQueen Branch and Crouch Branch would not be expected to have macroinvertebrate communities that are quite as diverse as Mill Creek. The macroinvertebrate data for these tributaries of Upper Three Runs are summarized in Table 5. The data from most of the parameters that were measured indicate that Mill Creek supports a richer macroinvertebrate community than the tributaries than receive NPDES discharges; however two of the three tributaries support relatively diverse communities. A total of 20 taxa were collected from the multiplate samplers in Mill Creek, as compared to 17 in Tims Branch, 11 in McQueen Branch and 5 in Crouch Branch. For qualitative and quantitative combined, 50 taxa were collected from Mill Creek, 41 from Tims Branch, 38 from McQueen Branch, and 8 from Crouch Branch. More EPT taxa were also collected from multiplates in Mill Creek (9) than the other tributaries ( 0 to 5). The density of organisms on the multiplates averaged 112 organisms $/ \mathrm{m}^{2}$ in Mill Creek, as compared to 73.3 in Tims Branch, 53.3 in McQueen Branch and just 8.9 organisms $/ \mathrm{m}^{2}$ in Crouch Branch. The community of Mill Creek was dominated by Ephemeroptera (55.4\%; primarily Stenonema; Table 6), Plecoptera (21.8\%; primarily Allocapnia) and midges (12.9\%). McQueen Branch was also dominated by these same groups, and also by Trichoptera, while dominant groups in Tims Branch were Annelida, midges, other dipterans, and Trichoptera (hydropsychids). In Crouch Branch, only midges (75\%) and odonates (25\%) were collected from the multiplates. With respect to functional feeding groups, Mill Creek was somewhat unusual in that no collector-filterers were collected from the multiplates. Feeding groups were fairly evenly divided between collector-gatherers $36.6 \%$, scrapers $(28.2 \%$ and shredders (24.3\%), with predators comprising $12.9 \%$ of the organisms collected. Tims Branch was dominated by collector-filterers (45.5\%) and collector-gatherers (37.1\%), while McQueen Branch was dominated by collector-gatherers $(52.1 \%)$ and scrapers (32.3\%). In Crouch Branch, both predators and shredders accounted for $37.5 \%$ of the organisms collected, while $25 \%$ of the organisms were collectorgatherers.

For the qualitative data, 39 species were collected from Mill Creek, 33 were collected from both Tims Branch and McQueen Branch, and just 3 were collected in Crouch 
Branch. More EPT taxa were collected in the qualitative samples from McQueen Branch (12) than Mill Creek (9). Tims Branch had 3 EPT taxa in the qualitative sample and none were found in Crouch Branch.

The data for the Upper Three Runs tributaries indicates that none of the tributaries that receive NPDES discharges support macroinvertebrate communities that are of the quality of that found in Mill Creek. However, the differences may be due, at least in part, to influences other than the NPDES discharges. The location that was sampled in Tims Branch is located just downstream from the old Steed's Pond dam. Although the dam no longer impounds what was Steed's Pond, the portion of the stream that flows through the old pond bed of Steed's Pond is braided and has little canopy. The high percentage of collector-filterers that was found in Tims Branch is probably directly related to algal production in the braided channels upstream from the sampling location. In addition, earlier investigations indicated that, at times, dissolved oxygen concentrations are very low in portions of Tims Branch upstream from the Steed's Pond. Intermittently low dissolved oxygen levels could explain the high percentage of annelids that were collected at this location.

Earlier macroinvertebrate surveys that were conducted in McQueen Branch in 1993 and 1994 (Specht, 1995a; Specht and Paller, 1995) both indicated that the macroinvertebrate community of the stream was more perturbed than was found in this study. As described in Section 2.1, both McQueen Branch and Crouch Branch were subject to intense scouring and siltation during construction of the DWPF. It appears that although McQueen Branch has largely recovered, some residual effects of the earlier perturbation may remain at this time.

Crouch Branch appears to be severely perturbed, as evidenced by the low number of taxa, total absence of EPT taxa, and very low numbers of organisms that were collected. Although Crouch Branch was also perturbed during construction of the DWPF, and it was sampled much closer to its headwaters than was McQueen Branch, a much more diverse community should be present if the stream is not subject to ongoing perturbations. Further studies may be necessary to identify the source of the perturbation, but possible effects from the NPDES discharges to the stream cannot be ruled out at this time.

The results of statistical analyses (Appendix A) indicate that Crouch Branch was significantly different than the reference locations with respect to the four parameters that were compared (total number of taxa, number of EPT taxa, density of organisms, and biotic index). Tims Branch had significantly fewer EPT taxa and a higher biotic index value than the reference stations. McQueen Branch was not significantly different that the reference locations with respect to any of the four parameters that were compared. In all, the macroinvertebrate data for Upper Three Runs indicated that Upper Three Runs contained a diverse macroinvertebrate community at both of the locations that were sampled, and there is no indication that SRS operations have impacted the macroinvertebrate community at Road C. In fact, the community at Road $C$ was found to be more diverse than Road 8-1. Two of the three tributaries of Upper Three Runs that receive NPDES discharges contain relatively diverse macroinvertebrate communities, whereas one (Crouch Branch) does not. Further investigations will be initiated to determine the source of the perturbation in this stream. 


\subsubsection{Fish}

Fish assemblage samples in the Upper Three Runs Creek drainage were collected from Upper Three Runs near Tyler Bridge Road, Upper Three Runs near Road A.2, Crouch Branch, McQueen Branch, Tims Branch, and Mill Creek (Appendix C). These sample locations generally corresponded to the macroinvertebrate sampling locations except that the macroinvertebrate samples from lower Upper Three Runs (i.e., the portion of Upper Three Runs potentially affected by NPDES discharges) were collected from near Road $C$ rather than from near Road A.2. Fish assemblages were not sampled near Road $\mathrm{C}$ to avoid interfering with other fish sampling programs being conducted in that area. The sample stations at Upper Three Runs near Road C, Crouch Branch, Tims Branch and McQueen Branch were located downstream from NPDES outfalls (Figure 1). Because Mill Creek does not receive NPDES discharges and is largely undisturbed, it was considered a control site and was pooled with the other control sites for statistical comparisons. The sample station at Upper Three Runs near Tyler Bridge Road was located upstream from the NPDES outfalls associated with the SRS. However, Upper Three Runs near Tyler Bridge may be influenced by offsite point or nonpoint pollution. For this and other reasons (discussed below), it was not considered a control site.

The average $|\mathrm{B}|$ at Upper Three Runs near Road A2 was 37.3 (Table 7). This value was not significantly different from control site values and was within the range of IBIs for unimpacted sites in the historical data set. In contrast, the IBI at Upper Three Runs near Tyler Bridge (average of 27.3), located upstream of all SRS NPDES outfalls and industrial areas, was significantly lower than at the control sites (average of 46.0 for Pen Branch Rd B, Pen Branch Rd. C, Meyers Branch, and Mill Creek) and below the values for undisturbed streams calculated for the historical data set (Figure 3). These results parallel those of the macroinvertebrate survey.

There are several possible reasons for depressed or apparently depressed biotic integrity at Upper Three Runs near Tyler Bridge. Offsite point or nonpoint discharges are a possibility, especially considering the fact that both fish and macroinvertebrate assemblages were depressed at Tyler Bridge. Further study would be necessary to confirm this hypothesis. Another factor that may have influenced the $|B|$ results is the unusual habitat at Upper Three Runs near Tyler Bridge. This portion of the stream was characterized by extensive overhanging brush (an average of $43 \%$ of the stream surface area) which made electrofishing difficult and may have reduced sampling efficiency. Reduced sampling efficiency could result in an apparent, rather than real, reduction in biotic integrity. Whether apparent or real, relatively low biotic integrity near Tyler Bridge was not the result of SRS NPDES discharges since all SRS NPDES outfalls were located downstream from Tyler Bridge.

The IBI for Mill Creek was 40, slightly below the IBI at the other three control sites (Table 7) but well within the upper half of the IBI values in the historical data set, as ${ }^{\circ}$ expected for this undisturbed stream. The average IBIs at MCQueen Branch and Tims Branch (38.7 and 38.7, respectively), both of which receives NPDES discharges were not significantly different from the IBIs at the control sites and within the range of IBIS for undisturbed streams in the historical data set. However, the IBI at Crouch Branch (29.3) was significantly lower than the IBI at the control sites and lower than any of the 
Table 7. IBI values from stream sites receiving NPDES discharges $(Y)$ and sites unaffected by NPDES discharges (N). There were three replicates at each sample site except for Four Mile Branch near Rd. C where there was insufficient space for three replicates.

\begin{tabular}{|c|c|c|c|c|c|c|c|c|c|c|}
\hline Sample site & NPDES & Rep. 1 & Rep. 2 & Rep. 3 & Average & St. dev. & St. error & Median & $\operatorname{Max}$ & Min \\
\hline Four Mile Branch Rd. 4 & $\bar{Y}$ & 18 & 26 & 22 & 22.0 & 4.0 & 2.3 & 22 & 26 & 18 \\
\hline Four Mile Branch Rd. C & $Y$ & 36 & 46 & & 41.0 & 7.1 & 5.0 & 41 & 46 & 36 \\
\hline Four Mile Branch Rd. A6 & $Y$ & 42 & 48 & 38 & 42.7 & 5.0 & 2.9 & 42 & 48 & 38 \\
\hline Four Mile Branch Rd. A & $Y$ & 42 & 40 & 50 & 44.0 & 5.3 & 3.1 & 42 & 50 & 40 \\
\hline Steel Creek & $Y$ & 38 & 30 & 30 & 32.7 & 4.6 & 2.7 & 30 & 38 & 30 \\
\hline Pen Branch Rd. B & $N$ & 46 & 48 & 48 & 47.3 & 1.2 & 0.7 & 48 & 48 & 46 \\
\hline Pen Branch Rd. C & $N$ & 50 & 50 & 46 & 48.7 & 2.3 & 1.3 & 50 & 50 & 46 \\
\hline McQueens Branch & $Y$ & 44 & 42 & 30 & 38.7 & 7.6 & 4.4 & 42 & 44 & 30 \\
\hline Tims Branch & $Y$ & 40 & 38 & 38 & 38.7 & 1.2 & 0.7 & 38 & 40 & 38 \\
\hline Pen Branch Rd. A & $Y$ & 44 & 46 & 46 & 45.3 & 1.2 & 0.7 & 46 & 46 & 44 \\
\hline Indian Grave Branch & $Y$ & 44 & 46 & 44 & 44.7 & 1.2 & 0.7 & 44 & 46 & 44 \\
\hline Meyers Branch & N & 44 & 46 & 46 & 45.3 & 1.2 & 0.7 & 46 & 46 & 44 \\
\hline Crouch Branch & $Y$ & 28 & 36 & 24 & 29.3 & 6.1 & 3.5 & 28 & 36 & 24 \\
\hline Upper Three Runs Rd. A2 & Y & 40 & 42 & 30 & 37.3 & 6.4 & 3.7 & 40 & 42 & 30 \\
\hline Upper Three Runs Tyler Br. & $\mathrm{N}$ & 22 & 30 & 30 & 27.3 & 4.6 & 2.7 & 30 & 30 & 22 \\
\hline Mill Creek & Y & 44 & 44 & 40 & 42.7 & 2.3 & 1.3 & 44 & 44 & 40 \\
\hline
\end{tabular}




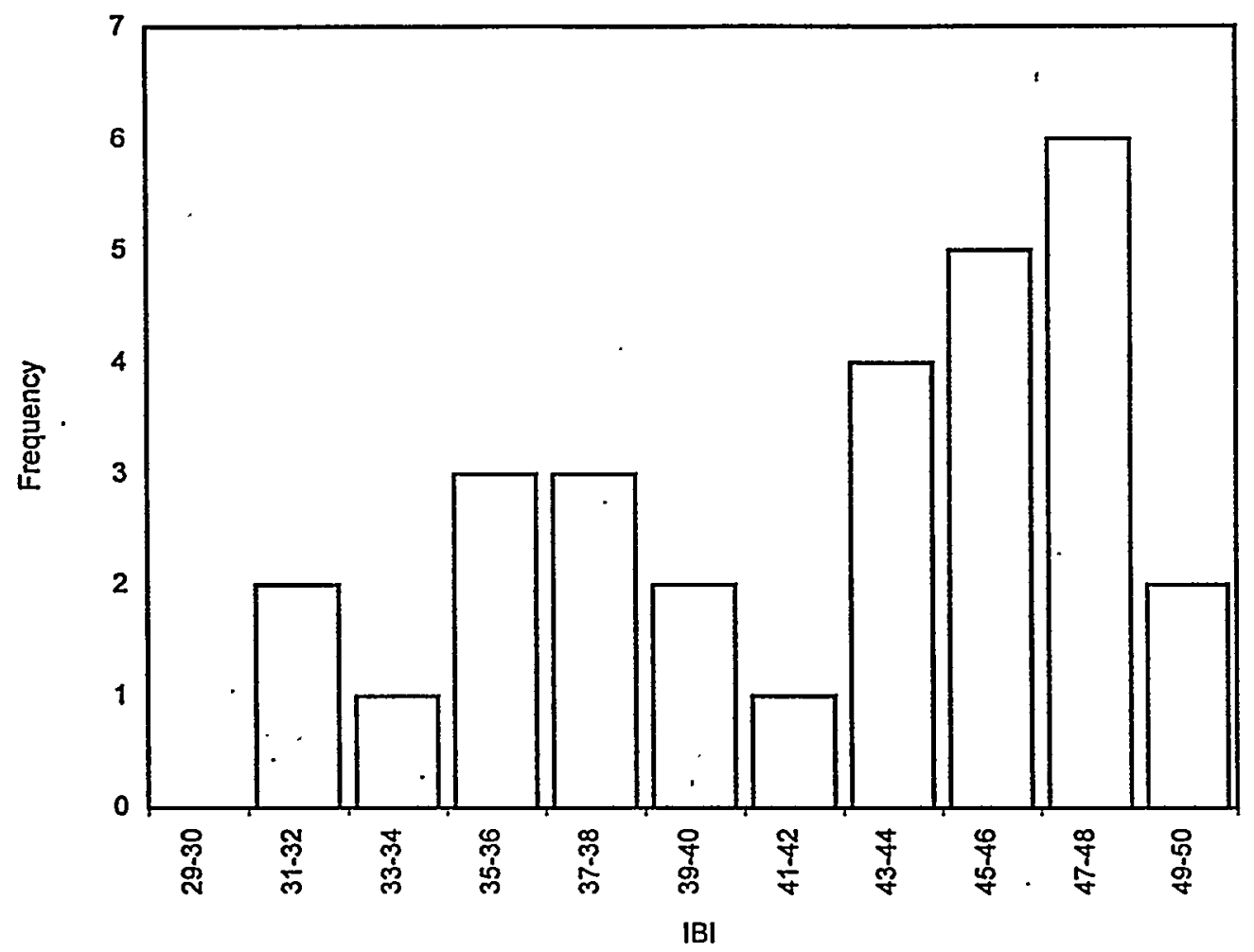

Figure 3. IBI values at 29 undisturbed stream sites located on and near the SRS. Samples are described more fully in Paller and Dyer (1997). 
IBIs for undisturbed streams in the historical data set (Figure 3). This low IBI value was matched by the macroinvertebrate data, which also indicated that numerous metrics were significantly depressed in Crouch Branch.

As indicated in the discussion of the macroinvertebrate data, there are several possible reasons for depressed biotic integrity in Crouch Branch including construction related impacts and NPDES discharges. It is also important to recognize that the habitat in Crouch Branch differed from that in the other streams included in this study. Crouch Branch was the shallowest and narrowest stream and characterized by considerable erosion (Table 8). The latter factor may be related to the comparatively steep gradient in Crouch Branch but might also be at least partly the result of stormwater runoff from

$H$ area located in the Crouch Branch headwaters. Further investigation may be necessary to definitively identify the factor or factors responsible for low biotic integrity in Crouch Branch.

\subsection{Fourmile Branch Watershed}

\subsubsection{Macroinvertebrates}

As described in Section 2.2, macroinvertebrates were collected from four locations in Fourmile Branch. Road $F$ is located upstream from all SRS discharges, Road $A$ is located downstream from all NPDES outfalls, and Roads $C$ and A-7 are located intermediately (Figure 1). All of the parameters that were measured indicate that the quality of Fourmile Branch's macroinvertebrate community improves in a downstream direction, and that the location that is upstream from all NPDES discharges is the most perturbed location that was sampled in Fourmile Branch (Table 9). For the multiplate data, a total of five taxa were collected at Road F, 11 were collected at Road C, 26 were collected at Road A-7 and 29 were collected at Road A. No EPT were collected at Road F, 1 was found at Road C, 9 at Road A-7 and 7 at Road A. The density of organisms on the multiplate samplers was also very low at Road $F$ (5.6 organisms $/ \mathrm{m}^{2}$, increasing to 17.8 at Road C, 341 at Road A-7, and 229 at Road A. The biotic index was highest at Road $F(8.15)$ and lowest at Road $A$ (5.95). The qualitative data showed similar patterns, with 15 species collected at Road F, 11 at Road C, 20 at Road A-7, and 27 at Road A. No EPT were found at Road F, 1 at Road $C$, and 6 at both Road A-7 and Road $A$. The biotic index values for the qualitative data showed a similar trend declining from 7.47 at Road $F$ to 5.95 at Road $A$. For both the qualitative and quantitative sampling combined, a total of 18 taxa were collected at Road $F, 19$ at Road C, 36 at Road A-7, and 41 at Road A.. Dipterans, annelids, and mollusks were the only taxa collected at Road $\mathrm{F}$. The community at Road $\mathrm{C}$ was dominated by midges $(62.5 \%)$, Coleoptera (12.5\%), and annelids (12.5\%). Caddisflies (primarily Cheumatopsyche) were the most abundant order collected at Road A-7, accounting for $69.1 \%$ of the organisms collected from the multiplate samplers (Tables 6 and 9 ). Mayflies (11.1\%; mostly Stenonema), and dipterans were also common. At Road A, the community was dominated by midges (59.7\%; primarily Parakiefferiella, Rheotanytarsus, and Corynoneura) and mayflies (32.5\%; primarily Stenonema). 
Table 8. Means for habitat variables. Variables were measured at nine transects at each sample station except at Four Mile Creek Rd. C, Upper Three Runs Tyler Bridge, and Upper Three Runs Road A.2 where variables were measured at six transects.

\begin{tabular}{|c|c|c|c|c|c|c|c|c|c|c|c|c|c|c|c|c|}
\hline Variable & 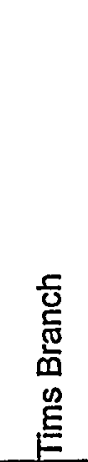 & 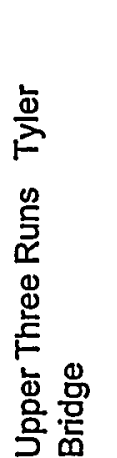 & 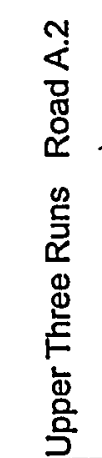 & 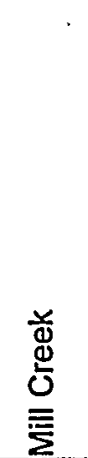 & 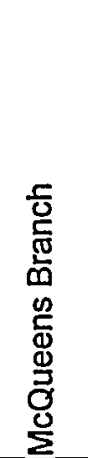 & 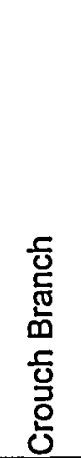 & 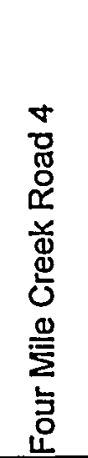 & 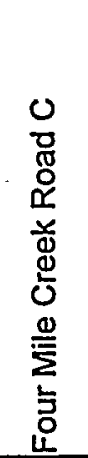 & 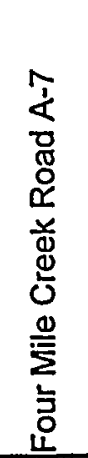 & 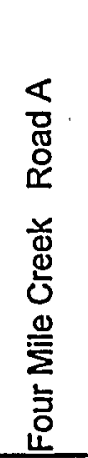 & 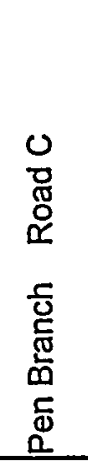 & 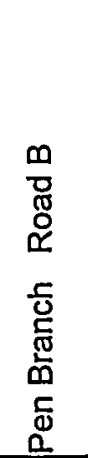 & 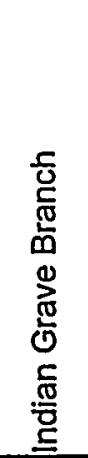 & 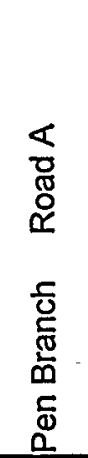 & 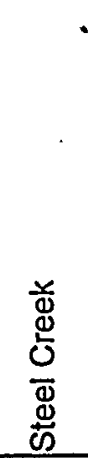 & $\begin{array}{l}\frac{5}{0} \\
\frac{0}{5} \\
\frac{0}{0} \\
\frac{n}{0} \\
\frac{0}{0} \\
\stackrel{0}{0} \\
\end{array}$ \\
\hline Width (m) & $\frac{5}{2.7}$ & 13.9 & 16.5 & 3.4 & 2.4 & 1.4 & 3.8 & 8.0 & 5.3 & 5.1 & 1.7 & 4.3 & 5.2 & 9.4 & 3.1 & 2.9 \\
\hline Depth (cm) & 16.0 & 44.1 & 111.3 & 21.4 & 13.7 & 6.7 & 35.1 & 33.7 & 35.6 & 64.1 & 10.8 & 9.5 & 35.3 & 37.4 & 12.8 & 12.4 \\
\hline Current velocity $(\mathrm{m} / \mathrm{s})$ & 0.18 & 0.21 & 0.38 & 0.19 & 0.27 & 0.24 & 0.08 & 0.22 & 0.18 & 0.12 & 0.03 & 0.16 & 0.12 & 0.11 & 0.14 & 0.36 \\
\hline Wood debris and leaves (\%)* & 8 & 12 & 10 & 14 & 4 & -3 & 4 & 13 & 9 & 17 & 27 & 5 & 3 & 3 & 13 & 13 \\
\hline Number logs and stumps & 2.3 & 1.2 & 3.7 & 3.4 & 1.4 & 1.8 & 3.0 & 6.5 & 2.6 & 4.0 & 1.2 & 2.2 & 2.9 & 2.8 & 1.2 & 1.6 \\
\hline Brush piles $(\%)^{*}$ & 22 & 23 & 14 & 17 & 9 & 6 & 14 & 13 & 13 & 12 & 16 & 9 & 8 & 6 & 12 & 22 \\
\hline Root masses (\%)* & 12 & 5 & 1 & 7 & 7 & 4 & 4 & 7 & 9 & 4 & 8 & 6 & 3 & 2 & 6 & 10 \\
\hline Macrophytes $(\%)^{\star}$ & 1 & 19 & 0 & 2 & 3 & 0 & 12 & 17 & 10 & 3 & 0 & 0 & 9 & 59 & 4 & 0 \\
\hline Overhanging bank vegetation (\%) & 8 & 43 & 3 & 12 & 32 & 3 & 14 & 28 & 26 & 22 & 5 & 11 & 19 & 22 & 10 & 5 \\
\hline Bank overhang $(\%)^{\star}$ & 7 & 0 & 0 & 6 & 8 & 2 & 1 & 0 & 6 & 2 & 11 & 3 & 2 & 1 & 4 & 4 \\
\hline Canopy cover $(\%)^{\star}$ & 85 & 20 & 72 & 89 & 82 & 87 & 73 & 76 & 82 & 31 & 100 & 85 & 51 & 38 & 72 & 93 \\
\hline Bank erosion ${ }^{\star \star \star}$ & 0.8 & 0.0 & 0.0 & 0.0 & 0.3 & 3.0 & 0.1 & 0.0 & 0.6 & 0.0 & 0.2 & 0.1 & 0.8 & 0.0 & 2.0 & 0.4 \\
\hline
\end{tabular}

* Percent variables refer to percent of stream bottom area covered by or overhung by the indicated variable

** Number of logs and stumps within a $3 \mathrm{~m}$ band on either side of the transect ( $6 \mathrm{~m}$ in total).

*** Estimated on a scale of 0-3 with 3 most severe 
Table 9. Summary of Macroinvertebrate Data, Fourmile Branch, November 1997

\begin{tabular}{|c|c|c|c|c|}
\hline & 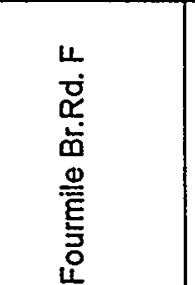 & 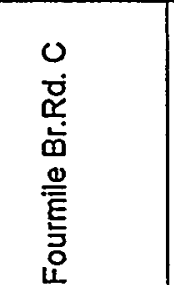 & 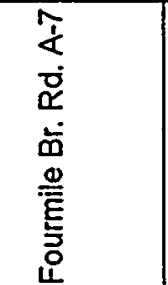 & 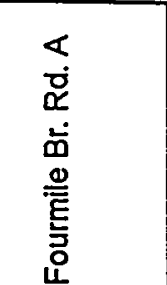 \\
\hline & Site 7 & Site 8 & Site 9 & Site 16 \\
\hline \multicolumn{5}{|c|}{ MULTIPLATE (QUANTITATIVE DATA) } \\
\hline Total \# species & 5 & 111 & 26 & 29 \\
\hline Mean \# species/replicate & 1.0 & 2.2 & 5.2 & 5.8 \\
\hline EPT Index & of & 1 & 9 & 7 \\
\hline Density (organisms $/ \mathrm{m}^{2}$ ) & 5.6 & 17.8 & 341.0 & 229.0 \\
\hline Total biomass $\left(\mathrm{g} / \mathrm{m}^{2}\right)$ & 0.0061 & 0.0054 & 0.1226 & 0.0315 \\
\hline NC Biotic index & 8.15 & 7.15 & 6.40 & 5.95 \\
\hline \multicolumn{5}{|c|}{$\begin{array}{l}\text { Relative Abundance of Major } \\
\text { Taxonomic Groups }\end{array}$} \\
\hline Annelida (worms) & 20.0 & 12.5 & 0.0 & 0.0 \\
\hline Mollusca (clams, snails) & 20.0 & 0.0 & 1.0 & 1.9 \\
\hline Crustacea & 0.0 & 0.0 & 0.0 & 1.5 \\
\hline Ephemeroptera & 0.0 & 0.0 & 11.1 & 32.5 \\
\hline Plecoptera & 0.0 & 6.3 & 2.9 & 0.5 \\
\hline Trichoptera & 0.0 & 0.0 & 69.1 & 2.4 \\
\hline Odonata & 0.0 & 6.3 & 0.0 & 0.5 \\
\hline Hemiptera & 0.0 & 0.0 & 0.0 & 0.0 \\
\hline Coleoptera & 0.0 & 12.5 & 2.3 & 0.5 \\
\hline Diptera (excluding midges) & 20.0 & 0.0 & 7.2 & 0.0 \\
\hline Diptera (midges) & 40.0 & 62.5 & 6.2 & 59.7 \\
\hline Chironomini & 0.0 & 12.5 & 2.9 & 2.4 \\
\hline Orthocladiinae & 20.0 & 6.3 & 3.3 & 37.9 \\
\hline Tanypodinae & 0.0 & 6.3 & 0.0 & 1.0 \\
\hline \begin{tabular}{|l|} 
Tanytarsini \\
\end{tabular} & 20.0 & 37.5 & 0.0 & 18.4 \\
\hline Other & 0.0 & 0.0 & 0.0 & 0.5 \\
\hline \multicolumn{5}{|c|}{$\begin{array}{l}\text { Relative Abundance of Functional } \\
\text { Feeding Groups }\end{array}$} \\
\hline Collector-gatherers & 40.0 & 28.1 & 11.1 & 58.0 \\
\hline Collector-filterers & 20.0 & 37.5 & 74.9 & 20.4 \\
\hline Predators & 20.0 & 18.8 & 1.0 & 2.4 \\
\hline Scrapers & 20.0 & 3.1 & 7.7 & 14.8 \\
\hline Shredders & 0.0 & 12.5 & 5.4 & 4.6 \\
\hline \multicolumn{5}{|c|}{$\begin{array}{l}\text { Relative Abundance of Functional } \\
\text { Feeding Group Biomass }\end{array}$} \\
\hline Collector-gatherers & $<0.1$ & 9.3 & 7.4 & 42.5 \\
\hline Collector-filterers & $<0.1$ & $<0.1$ & 63.1 & 5.4 \\
\hline Predators & 100.0 & 81.5 & 15.9 & 7.0 \\
\hline Scrapers & $<0.1$ & 9.3 & 11.7 & 45.1 \\
\hline Shredders & $<0.1$ & $<0.1$ & 1.9 & $<0.1$ \\
\hline \multicolumn{5}{|c|}{ QUALITATIVE DATA } \\
\hline Total \# species & 15 & 11 & 20 & 27 \\
\hline EPT Index & 0 & 1 & 6 & 6 \\
\hline NC Biotic index & 7.47 & 6.63 & 6.56 & 5.95 \\
\hline \multicolumn{5}{|c|}{ QUALITATIVE AND QUANTITATIVE DATA COMBINED } \\
\hline Total \# species & 18 & 19 & 36 & 41 \\
\hline
\end{tabular}


These data clearly indicate that Fourmile Branch is perturbed upstream from all NPDES discharges and that the quality of the stream increases in a downstream direction. The portion of Fourmile Branch just upstream from Road $F$ is a shallow marshy area that generally has low water velocity. Although dissolved oxygen in the stream at Road $F$ was $8.9 \mathrm{mg} / \mathrm{l}$ at the time of sampling (Table 10), it is likely that oxygen levels are low during the summer months. Data collected from Fourmile Branch at Road $\mathrm{C}$ during the summer of 1993 (Specht, 1995a) indicated that this portion of the stream had a dissolved oxygen concentration of $0.8 \mathrm{mg} / \mathrm{l}$ at the time of sampling. Numerous portions of Fourmile Branch have been impounded by beaver dams, and it is likely that these dams result in low dissolved oxygen concentrations downstream from the impounded areas during the summer months. If the macroinvertebrate community is subjected to low dissolved oxygen concentrations periodically, it is likely that the community does not have time to recover completely during the cooler months.

Table 10. Physical/Chemical Data for SRS Stream Sampling Locations, December 8, 1997

\begin{tabular}{|c|c|c|c|c|}
\hline Location & $\begin{array}{l}\text { Dissolved } \\
\text { Oxygen (mg/l) }\end{array}$ & $\mathrm{pH}$ & $\begin{array}{l}\text { Specific } \\
\text { Conductance } \\
(\mu \mathrm{mhos} / \mathrm{cm})\end{array}$ & Temperature $\left({ }^{\circ} \mathrm{C}\right)$ \\
\hline \multicolumn{5}{|l|}{ Upper Three Runs } \\
\hline Tims Branch & 11.8 & 6.79 & 63 & 4.0 \\
\hline Mill Creek & 11.4 & 6.80 & 61 & 7.0 \\
\hline McQueen Br. & 10.1 & 6.47 & 50 & 7.5 \\
\hline Crouch Br. & 9.9 & 6.81 & 72 & 13.5 \\
\hline UTR Rd. 8-1 & 10.8 & 5.74 & 21 & 9.8 \\
\hline UTR Rd. C & 11.9 & 5.85 & 27 & 8.2 \\
\hline \multicolumn{5}{|l|}{ Fourmile Branch } \\
\hline Rd. $F$ & 8.9 & 5.16 & 30 & 4.5 \\
\hline Rd. C & 10.0 & 6.33 & 52 & 8.7 \\
\hline Rd. A-7 & 11.0 & 6.49 & 67 & 6.1 \\
\hline Rd. A & 10.1 & 6.61 & 70 & 7.8 \\
\hline \multicolumn{5}{|l|}{ Pen Branch } \\
\hline Rd. C & 10.6 & 6.39 & 42 & 6.2 \\
\hline Rd. $B$ & 9.8 & 6.80 & 55 & 9.0 \\
\hline Indian Grave Br. & 9.6 & 5.83 & 119 & 10.0 \\
\hline & 10.2 & 6.72 & 63 & 8.9 \\
\hline \multicolumn{5}{|l|}{ Steel Creek } \\
\hline Steel Cr. Near Rd. C & 9.7 & 6.47 & 42 & 11.0 \\
\hline Meyers Br. & 9.2 & 6.39 & 53 & 8.5 \\
\hline
\end{tabular}

Other studies conducted in Fourmile Branch at Road $F$ indicate that Ceriodaphnia dubia does poorly when cultured in water from Fourmile Branch (Specht 1995b). During an investigation conducted for 12 months during 1994, water collected from this location was always either acutely or chronically toxic to Ceriodaphnia. In 1995, a Toxicity Identification Evaluation was performed to determine the cause of the toxicity (ETT Environmental, 1995a, 1995b). The results of the TIE indicated that naturally 
occurring iron was responsible for the observed toxicity. The iron is believed to leach from wetland soils, as a result of the low $\mathrm{pH}$ of the water.

As discussed in Section 3.2.2, data from Fourmile Branch at Road F was not included as data from reference locations for statistical comparisons, since this location was obviously perturbed. A statistical analysis of the data indicated that Fourmile Branch at Road $\mathrm{C}$ was significantly different from the reference locations with respect to three of the four parameters that were measured. This location had fewer macroinvertebrates, fewer EPT taxa, and a higher biotic index value than the reference locations. The other two locations in Fourmile Branch (Road A-7 and Road A were not significantly different that the reference locations with respect to any of the four parameters that were compared. In conclusion, the macroinvertebrate data from Fourmile Branch indicated that the upstream portions of Fourmile Branch are perturbed, but the perturbation does not appear to be related to SRS discharges, since the most upstream station, which is above all discharges to the stream, is the most perturbed. The impacts are most likely due to periodically low levels of dissolved oxygen, and possibly elevated concentrations of naturally occurring iron.

\subsubsection{Fish}

Fish sampling station locations differed slightly from macroinvertebrate sampling locations in Four Mile Creek. Both fish and macroinvertebrate surveys were conducted near Road C, Road A-7, and Road A (Figure 1) (Appendix C). Macroinvertebrate surveys were also conducted near Road F; however, fish were not sampled at this location because the stream was too shallow and narrow (except in beaver ponds) to support many fish. Instead, an additional fish survey was conducted near Road 4 (Figure 1). There were no fish sampling stations on Four Mile Creek located upstream from all NPDES discharges. The control sites used for statistical analysis of the Four Mile Creek sampling stations were the four in Pen Branch, Meyers Branch, and Mill Creek.

Average IBI values at the Four Mile Creek sampling stations were 44.0 at Road $A, 42.7$ at Road A-6, 41.0 at Road C, and 22.0 at Road 4 (Table 7). Only the IBI from Four Mile Creek near Road 4 was significantly lower than the mean IBI for the control sites. Comparison of this value (22.0) with the historical data indicated that it was substantially below any IBI recorded in an undisturbed stream (Figure 3 ). These findings paralleled those of the macroinvertebrate survey which also indicated a progressive decrease in biotic integrity in an upstream direction with an unusually low biotic integrity occurring at the most upstream site (Road F).

The results of the macroinvertebrate survey indicated depressed biotic integrity at Road $F$, which was upstream of all of the NPDES outfalls, possibly as a result of low dissolved oxygen levels in water discharged from beaver dams during the summer or naturally occurring high iron levels. These factors may have also acted to depress the fish based IBI at Road 4, which is approximately $4.5 \mathrm{~km}$ downstream from Road $F$ (Figure 1). A beaver pond was located approximately $50 \mathrm{~m}$ upstream from the uppermost fish sampling segment at Road 4, and a reddish flock that may have precipitated ferric iron was observed in some of the fish sampling areas near Road C. 
Definitive identification of factors responsible for decreased biotic integrity in Four Mile Creek near Roads 4 and $C$ will require water quality and/or bioassay studies.

\subsection{Pen Branch Watershed}

\subsubsection{Macroinvertebrates}

Macroinvertebrates were collected at four locations in the Pen Branch watershed: Pen Branch at Road C and Road B, both of which are upstream from all SRS discharges; Indian Grave Branch just downstream from the new cooling tower, which is downstream from all NPDES discharges from K Area, and Pen Branch at Road A, which is downstream from the confluence of Indian Grave Branch with Pen Branch, and therefore downstream from all NPDES discharges to Pen Branch. No upstream reference location could be sampled on Indian Grave Branch, since the discharges from K Area enter the headwaters of the stream.

The macroinvertebrate data collected from the three locations in Pen Branch and from one location in Indian Grave Branch indicate that the locations were fairly similar with respect to many of the metrics that were measured (Table 11). Fewer taxa were collected from the headwater station in Pen Branch (Road C) than at the other locations, but this location was tied with Road B for the most taxa collected during qualitative sampling (34). For qualitative and quantitative sampling combined, the total number of taxa collected ranged from 38 to 45 . Fewer EPT taxa were collected with multiplate samplers from Indian Grave Branch (4) and Road A (3) than at the upstream stations, but the number of EPT collected in the qualitative sampling was similar. Seven EPT taxa were collected at Road A, Road B, and in Indian Grave Branch, while 9 were collected at Road C. The density of organisms collected from the multiplates was somewhat lower at the two locations that are post-thermal (Indian Grave Branch and Pen Branch at Road $A$ ) than at the two unimpacted locations. The biotic index values for the post-thermal stations (6.54 to 6.58) were also higher than for the stations that had never received thermal discharges (5.16 and 5.51). Species composition was the most obvious difference among the four locations. The most upstream location (Road C) was dominated by mayflies (62.5\%; primarily Stenonema; Table 6). The relative abundance of mayflies declined in a downstream direction, to $46.9 \%$ at Road $B$. and $9.3 \%$ at $A$, while the relative abundance of dipterans increased from $20.5 \%$ at Road C to $76.7 \%$ at Road A. Plecoptera (primarily Allocapnia and Taeniopteryx), which accounted for $20.5 \%$ and $15 \%$ of the macroinvertebrates collected from Roads $C$ and $B$, respectively, were conspicuously absent from the post-thermal stations. Trichoptera (primarily Cheumatopsyche) were relatively common at Road $B(12.2 \%)$ but relatively uncommon at the other three sites (0 to $3.5 \%$ ). Collector-gatherers and shredders were the most abundant feeding groups at all four sites.

A statistical analysis of the data (Appendix A) indicated that Pen Branch at Road A had significantly fewer EPT taxa and a higher biotic index value that the reference locations and Indian Grave Branch had a higher biotic index value than the reference locations. These data indicated that the macroinvertebrate communities of Indian Grave Branch and Pen Branch at Road $A$ differed somewhat from the communities at Roads $C$ and $B$. Both Indian Grave Branch and Pen Branch are downstream from NPDES discharges from K Area, but both of these locations were also exposed to a severe thermal regime 
Table 11. Summary of Macroinvertebrate.Data, Pen Branch and Steel Creek, November 1997

\begin{tabular}{|c|c|c|c|c|c|c|}
\hline & \multicolumn{4}{|c|}{ Pen Branch System } & \multicolumn{2}{|c|}{ Steel Creek System } \\
\hline & $\begin{array}{l}0 \\
\dot{0} \\
\alpha \\
\dot{0} \\
\dot{0} \\
\frac{\Phi}{0} \\
\underline{Q}\end{array}$ & 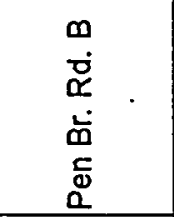 & 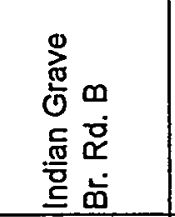 & 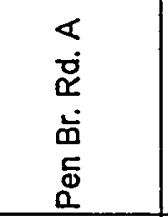 & 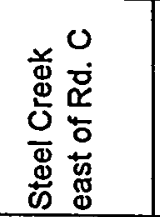 & 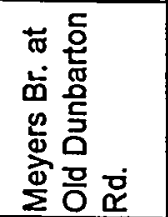 \\
\hline & Site 10 & Site 11 & Site 12 & Site 13 & Site 14 & Site 15 \\
\hline \multicolumn{7}{|c|}{ MULTIPLATE (QUANTITATIVE DATA) } \\
\hline Total \# species & 10 & 21 & 23 & 22 & 17| & 18 \\
\hline Mean \# species/replicate & 2.0 & 4.2 & 4.6 & 4.4 & 3.4 & 3.6 \\
\hline EPT Index & 7 & 7 & 4 & 3 & 4 & 6 \\
\hline Density (organisms $/ \mathrm{m}^{2}$ ) & 124.0 & 163.0 & 101.0 & 95.6 & 71.1 & 180.0 \\
\hline Total biomass $\left(\mathrm{g} / \mathrm{m}^{2}\right)$ & 0.0513 & 0.0654 & 0.0702 & 0.1356 & 0.0428 & 0.0221 \\
\hline NC Biotic index & 5.51 & 5.16 & 6.58 & 6.54 & 5.81 & 4.81 \\
\hline \multicolumn{7}{|c|}{$\begin{array}{l}\text { Relative Abundance of Major } \\
\text { Taxonomic Groups }\end{array}$} \\
\hline Annelida (worms) & 0.0 & 0.0 & 1.1 & 0.0 & 0.0 & 0.6 \\
\hline Mollusca (clams, snails) & 0.0 & 0.7 & 1.1 & 2.3 & 3.1 & 0.0 \\
\hline Crustacea & 0.0 & 0.7 & 1.1 & 0.0 & 0.0 & 0.0 \\
\hline Ephemeroptera & 62.5 & 46.9 & 28.6 & 9.3 & 35.9 & 14.2 \\
\hline Plecoptera & 15.2 & 19.7 & 0.0 & 0.0 & 23.4 & 9.3 \\
\hline Trichoptera & 0.0 & 12.2 & 2.2 & 3.5 & 0.0 & 2.5 \\
\hline Odonata & 1.8 & 0.0 & 2.2 & 3.5 & 1.6 & 0.0 \\
\hline Hemiptera & 0.0 & 0.0 & 0.0 & 0.0 & 0.0 & 0.0 \\
\hline Coleoptera & 0.0 & $4: 8$ & 3.3 & 2.3 & 0.0 & 0.0 \\
\hline Diptera (excluding midges) & 0.0 & 0.0 & 0.0 & 0.0 & 1.6 & $\overline{0.6}$ \\
\hline Diptera (midges) & 20.5 & 15.0 & 60.4 & 76.7 & 32.8 & 72.8 \\
\hline Chironomini & 19.6 & 2.0 & 42.9 & 32.6 & 17.2 & 29.6 \\
\hline Orthocladiinae & 0.0 & 10.2 & 7.7 & 24.4 & 9.4 & 26.5 \\
\hline Tanypodinae & 0.0 & 7.0 & 7.7 & 2.3 & 3.1 & 3.1 \\
\hline \begin{tabular}{|l} 
Tanytarsini \\
\end{tabular} & 0.9 & 2.0 & 2.2 & 17.4 & 3.1 & 13.6 \\
\hline Other & 0.0 & 0.0 & 0.0 & 2.4 & 1.6 & 0.0 \\
\hline \multicolumn{7}{|c|}{$\begin{array}{l}\text { Relative Abundance of Functional } \\
\text { Feeding Groups }\end{array}$} \\
\hline Collector-gatherers & 42.4 & 36.4 & 46.2 & 40.7 & 34.4 & 49.4 \\
\hline Collector-filterers & 0.9 & 15.0 & 3.3 & 20.9 & 4.7 & 15.4 \\
\hline \begin{tabular}{|l|} 
Predators \\
\end{tabular} & 3.6 & 5.4 & 12.1 & 8.1 & 9.4 & 6.2 \\
\hline Scrapers & 29.9 & 23.1 & 16.5 & 8.1 & 21.1 & 6.8 \\
\hline Shredders & 23.2 & 20.1 & 22.5 & 22.1 & 30.5 & 22.2 \\
\hline \multicolumn{7}{|c|}{$\begin{array}{l}\text { Relative Abundance of Functional } \\
\text { Feeding Group Biomass }\end{array}$} \\
\hline Collector-gatherers & 39.2 & $<0.1$ & 87.0 & 3.3 & 23.6 & 50.7 \\
\hline Collector-filterers & 1.4 & 50.5 & 1.1 & 0.9 & $<0.1$ & 6.8 \\
\hline Predators & 14.6 & 0.9 & 2.6 & 93.0 & 46.3 & 10.4 \\
\hline Scrapers & 37.8 & 39.1 & 9.3 & 2.3 & 23.6 & 29.4 \\
\hline Shredders & 7.0 & 9.5 & $<0.1$ & 0.5 & 6.5 & 2.7 \\
\hline \multicolumn{7}{|c|}{ QUALITATIVE DATA } \\
\hline Total \# species & 34 & 34 & 25 & 30 & 33 & 40 \\
\hline EPT Index & $\overline{9}$ & 7 & 7 & 7 & 6 & 17 \\
\hline NC Biotic Index & 6.1 & 6.07 & 7.05 & 6.82 & 6.77 & 5.68 \\
\hline \multicolumn{7}{|c|}{ QUALITATIVE AND QUANTITATIVE DATA COMBINED } \\
\hline Total \# species & 38 & 44 & 38 & 45 & 41 & 47 \\
\hline
\end{tabular}


and high flows until $K$ Reactor was shut down in 1988. Specht and Paller (1995) found that macroinvertebrate communities of SRS's post-thermal streams differed substantially from the streams that had never received thermal discharges, primarily due to differences in stream habitat. Therefore, it is likely that the differences were due to habitat differences resulting from the thermal history of the streams rather than to the effects of NPDES discharges.

\subsubsection{Fish}

NPDES outfalls within the Pen Branch watershed discharge into Indian Grave Branch, a tributary of Pen Branch (Figure 1). One fish sampling station was located within Indian Grave Branch downstream of the outfalls and one was located in Pen Branch downstream from the confluence of Pen Branch and Indian Grave (Appendix C). Both were potentially subject to impacts from the NPDES outfalls, particularly the Indian Grave Branch station which was closest to the outfalls. There were two additional fish sampling stations in the Pen Branch drainage located above the confluence of indian Grave Branch and Pen Branch (Pen Branch Rd. B and Pen Branch Rd. C) Because they were located in undisturbed areas and did not receive NPDES discharges, these sampling stations were considered control sites and grouped with the other two control sites for statistical testing.

Mean IBI values at the Indian Grave Branch-and Pen Branch sample stations that received NPDES discharges averaged 44.7 and 45.3, respectively. These values were not significantly different from the mean IBI for the four control sites (i.e., 46.0, Table 7). In addition, the mean IBI values at these two stations were well within the range of $\mid \mathrm{BI}$ values characteristic of undisturbed streams as indicated by the historical data (Figure 3). These results indicate that the NPDES outfalls on Indian Grave Branch have not deleteriously affected biotic integrity in Pen Branch or Indian Grave Branch.

\subsection{Steel Creek Watershed}

\subsubsection{Macroinvertebrates}

- Macroinvertebrates were collected from two locations in the Steel Creek watershed: Steel Creek near Road C, which is downstream from all P-Area discharges to the stream and approximately one $\mathrm{km}$ upstream from the upper end of $L$ Lake; and Meyers Branch at Old Dunbarton Road, which is essentially unimpacted by SRS activities. As discussed in Section 2.4, sampling was not performed farther downstream in Steel Creek, because NPDES discharges enter directly into $L$ Lake, the discharges are minimal, and it would not be possible to distinguish between ecosystem changes resulting from the impoundment of Steel Creek and effluent effects. In Steel Creek, 17 taxa were collected from the multiplate samplers, 33 were collected from qualitative sampling, and 41 were collected in all (Table 11). In Meyers Branch, 18 taxa were collected from the multiplates, 40 were collected during qualitative sampling, and 47 taxa were collected in all. More EPT taxa were collected from Meyers Branch than in Steel Creek from both the multiplate sampling (6 taxa vs. 4) and the qualitative sampling (17 taxa vs. 6). The density of organisms on the multiplates was higher in Meyers Branch $\left(180\right.$ organisms $/ \mathrm{m}^{2}$ ) than in Steel Creek $\left(71.1\right.$ organisms $\left./ \mathrm{m}^{2}\right)$. The biotic index values were lower in Meyers Branch than Steel Creek for both the multiplate data 
(4.81 vs. 5.81 ) and the qualitative sampling (5.68 vs. 6.77). The macroinvertebrate community on the multiplate samplers in Steel Creek was dominated by mayflies (35.9\%; primarily Stenonema), midges (32.8\%; primarily Polypedilum), and stoneflies (23.4\%; primarily Taeniopteryx). In Meyers Branch, $72.8 \%$ of the organisms collected were midges (primarily Polypedilum and Parametriocnemus), with mayflies and stoneflies accounting for 14.2 and $9.3 \%$ of the organisms collected, respectively.

The results of statistical analyses of the data indicate that Steel Creek did not differ significantly from the reference stations for any of the four parameters that were measured (density, number of taxa, number of EPT taxa, and NCBI). The macroinvertebrate data for Steel Creek indicated that the stream supports a reasonably diverse macroinvertebrate community that is not dominated by pollution tolerant taxa. However, the community is not of the quality supported by Meyers Branch. Steel Creek received thermal discharges from $P$ Reactor prior to the construction of Par Pond, and it is possible that there are still differences in habitat between the two streams.

\subsubsection{Fish}

Fish were collected from sample stations in the portion of Steel Creek upstream from $L$ Lake and Meyers Branch. The sample station in Steel Creek was located approximately $1.75 \mathrm{~km}$ downstream from several NPDES outfalls. The Meyers Branch station, in contrast, does not receive NPDES discharges and is largely undisturbed. It was considered a control site and grouped with the other three control sites for statistical analysis.

The mean IBI value for the portion of Steel Creek upstream from $L$ Lake was 32.7. This value was significantly lower than the mean IBI for the four control sites (46.0, Table 7). Furthermore, it was at the lower end of the range of IBI values calculated for undisturbed streams in the historical data base (Figure 3). These results indicate that biotic integrity in upper Steel Creek is below that expected in most, but not all, undisturbed streams.

It is possible that the relatively low biotic integrity observed in Steel Creek was habitat related. The banks of Steel Creek were severely eroded (Table 8 ). The stream channel was cut more deeply than is typical of most SRS streams and bank collapse was evident in a number of areas raising the possibility of intermittent siltation and general habitat instability. Also, the upper portion of Steel Creek is isolated from the rest of the stream by L Lake, which serves as a source pool for emigrating lake fishes. The only shiner found in upper Steel Creek was the coastal shiner (Appendix C). This species is typically uncommon in small streams but common in L Lake (Paller 1996).

Lastly, it is possible that the somewhat degraded fish community in Steel Creek was the result of previous discharges from the P-014 sanitary outfall, which constitutes the headwaters of Steel Creek. Discharge from this outfall was chlorinated until 1995 when effluent chlorination was halted at all SRS outfalls (Rhonda Huffines, personal communication). Residual chlorine concentrations were never measured at the P-014 outfall, but often reached very high concentrations (in excess of $10 \mathrm{mg} / \mathrm{l}$ ) in other SRS sanitary discharges. Such concentrations are highly toxic and may eliminate fish from long segments of the receiving stream (Paller et al. 1987). Therefore, it is possible that 
many fish species were eliminated by previous (but not current) effluent toxicity. When effluent chlorination was discontinued, recolonization of upper Steel Creek by a full range of typical stream fishes was prevented by L Lake which blocked the immigration of fishes from lower Steel Creek. In contrast, colonization by insects, many of which are capable of flight, would have been easier, perhaps accounting for the somewhat higher biotic integrity indicated by the macroinvertebrate data.

\subsection{Savannah River}

All discharges from SRS NPDES outfalls ultimately flow into the Savannah River because all SRS streams are tributaries of the Savannah River. However, NPDES outfalls on SRS streams discharge into the upper or midreaches of these streams (Table 2), resulting in a long flow path to the Savannah River and considerable dilution of the effluents before they reach the river. Biological sampling has demonstrated that most of these outfalls have not affected their receiving streams. In the few cases where possible effects were observed (e.g., Crouch Branch), they were confined to headwaters and did not persist downstream. Therefore, it is reasonable to conclude that NPDES outfalls located on SRS streams have not affected the Savannah River.

Unlike the majority of the SRS NPDES outfalls, which discharge into tributary streams, there are six NPDES outfalls (Table 2) that are located near the Savannah River. Effluents from these outfalls are discharged into the Savannah River Swamp or flow. directly into the Savannah River through a relatively short ditch. Upon entering the river, all effluents are highly diluted by mixing with Savannah River water. Previous biological surveys (1983 to 1985) indicated the presence of diverse and healthy fish and macroinvertebrate communities in the Savannah River with no evidence of impacts related to SRS NPDES discharges (Specht 1987).

\subsection{Conclusions}

The results of the macroinvertebrate and fish surveys conducted during this study were generally in close agreement. Both indicated that most SRS streams were .

characterized by high biotic integrity and unaffected by SRS NPDES discharges. A prominent exception was Crouch Branch which, as indicated by both the macroinvertebrate and fish data, was significantly degraded. Further research will be - required to determine whether this degradation was related to NPDES discharges, habitat, or other factors. Degradation was also observed in upper Fourmile Branch and upper Steel Creek, but in these cases was probably related to factors other than NPDES discharges. Factors that may have depressed biotic integrity in these streams reaches included previous thermal impacts, reservoir impoundment related effects, possible construction impacts, and naturally occurring habitat factors.

\subsection{References}

Angermeier, P.L. and J.R. Karr. 1994. Biological integrity versus biological diversity as policy directives. BioScience 44:690-697.

ETT Environmental, Inc. 1995a. Chronic Toxicity Identification Evaluation, Phase I, Fourmile Branch. June 1995. ETT Environmental, Inc. Greenville, SC. 
ETT Environmental, Inc. 1995b. Chronic Toxicity Identification Evaluation, Phase II, Fourmile Branch Surface Water At The Savannah River Site. July 1995. ETT Environmental, Inc. Greenville, SC.

Lenat, D.R. 1993. A biotic index for the southeastern United States: derivation and list Of Tolerance values, with criteria for assigning water-quality ratings. J. North American Benthological Socity 12(3):279-290.

Paller, M.H 1996. L Lake Fish community and water chemistry. WSRC-TR-96-0163. Savannah River Technology Center, Aiken,SC.

Paller, M.H., M.J.M. Reichert, and J.M. Dean. 1996. Use of fish communities to assess Environmental impacts in South Carolina coastal plain streams. Transactions of the American Fisheries Society 125:633-644.

Plafkin,J.L.,M.T.Barbour, K.D. Porter, S.K.Gross, and R. M. Hughes. 1989. Rapid Bioassessment Protocols for use in streams and rivers. . U.S. Environmental Protection Agency. EPPA/444/4-89-001.

Specht, W.L. 1995a. Results of Macroinvertebrate Sampling Conducted at 33 SRS Stream Locations, July-August 1993. WSRC-TR-95-0006. Westinghouse Savannah River Company, Aiken, SC.

Specht, W.L. 1995b. Reproductive Success and Mortality Rates of Ceriodaphnia dubia Maintained in Water from Upper Three Runs, Pen Branch, and Fourmile Branch. WSRC-TR-95-0005. Westinghouse Savannah River Company, Aiken,SC.

Specht, W.L. 1987. Comprehensive Cooling Water Study, Final Report, Vol. 4: Aquatic Ecology. DP-1739-5, E.I.du Pont de Nemours and Company, Savannah River Laboratory, Aiken, SC.

Specht, W.L. and M.H.Paller. 1995. Rapid Bioassessment Methods for Assessing Stream Macroinvertebrate Communities On the Savannah River Site. WSRC-TR-950351. Westinghouse Savannah River Company, Aiken, SC. 


\section{APPENDIX A}

\section{Statistical Results for Macroinvertebrate Data}




\section{Statistical Analyses for Density of Organisms}

One Way Analysis of Variance

Data source: Data 1 in Notebook

Normality Test: $\quad$ Failed $(\mathrm{P}=<0.001)$

Test execution ended by user request, ANOVA on Ranks begun

Kruskal-Wallis One Way Analysis of Variance on Ranks

Tuesday, March 24, 1998, 08:41:49

Data source: Data 1 in Notebook

\begin{tabular}{lrrr} 
Group & \multicolumn{1}{c}{$N$} & Missing & \\
C & 20 & 0 & \\
MCQ & 5 & 0 & \\
CR & 5 & 0 & \\
FM-C & 5 & 0 & \\
FM-A7 & 5 & 0 & \\
IG-B & 5 & 0 & \\
PB-A & 5 & 0 & \\
SC & 5 & 0 & \\
FM-A & 5 & 0 & \\
TB & 5 & 0 & \\
& & & \\
Group & Median & $25 \%$ & $75 \%$ \\
C & 127.750 & 102.800 & 155.550 \\
MCQ & 61.100 & 33.350 & 73.600 \\
CR & 5.600 & 4.200 & 11.150 \\
FM-C & 16.700 & 9.725 & 27.800 \\
FM-A7 & 344.400 & 286.075 & 401.400 \\
IG-B & 83.300 & 62.525 & 120.850 \\
PB-A & 55.600 & 26.400 & 170.875 \\
SC & 50.000 & 22.250 & 95.875 \\
FM-A & 227.800 & 115.250 & 333.350 \\
TB & 83.300 & 37.500 & 105.600
\end{tabular}

$\mathrm{H}=43.750$ with 9 degrees of freedom. $(\mathrm{P}=<0.001)$

The differences in the median values among the treatment groups are greater than would be expected by chance; there is a statistically significant difference $(\mathrm{P}=<0.001)$

To isolate the group or groups that differ from the others use a multiple comparison procedure.

Multiple Comparisons versus Control Group (Dunn's Method) :

$\begin{array}{lrrrr}\text { Comparison } & \text { Diff of Ranks } & \mathbf{p} & \mathbf{Q} & \mathbf{P}<\mathbf{0 . 0 5} \\ \text { CR vs C } & 37.375 & 10 & 3.957 & \text { Yes } \\ \text { FM-C vs C } & 33.475 & 9 & 3.544 & \text { Yes } \\ \text { MCQ vs C } & 21.775 & 8 & 2.305 & \text { No } \\ \text { SC vs C } & 20.275 & 7 & 2.146 & \text { No Test Needed } \\ \text { FM-A7 vs C } & 18.425 & 6 & 1.951 & \text { No Test Needed } \\ \text { TB vs C } & 14.775 & 5 & 1.564 & \text { No Test Needed } \\ \text { PB-A vs C } & 13.175 & 4 & 1.395 & \text { No Test Needed } \\ \text { IG-B vs C } & 10.475 & 3 & 1.109 & \text { No Test Needed } \\ \text { FM-A vs C } & 8.425 & 2 & 0.892 & \text { No Test Needed }\end{array}$




\section{Statistical Analyses for Density of Organisms (continued)}

Mann-Whitney Rank Sum Test

Tuesday, March 24, 1998, 08:42:38

Normality Test: $\quad$ Failed $(P=0.002)$

\begin{tabular}{lccc} 
Group & $\mathbf{N}$ & \multicolumn{2}{c}{ Missing } \\
C & 20 & 0 & \\
UTR-8 & 5 & 0 & \\
& & 0 & \\
Group & Median & $25 \%$ & $75 \%$ \\
C & 127.750 & 102.800 & 155.550 \\
UTR-8 & 61.100 & 55.600 & 123.600
\end{tabular}

$\mathrm{T}=38.500 \mathrm{n}(\mathrm{small})=5 \mathrm{n}(\mathrm{big})=20 \quad(\mathrm{P}=0.077)$

The differences in the median values among the two groups are not great enough to exclude the possibility that the difference is due to random sampling variability; there is not a statistically significant difference $(P=0.077)$ 


\section{Statistical Analyses for Taxa Richness}

One Way Analysis of Variance

Data source: Data 1 in Notebook

Normality Test: $\quad$ Failed $\quad(P=0.023)$

Test execution ended by user request, ANOVA on Ranks begun

Kruskal-Wallis One Way Analysis of Variance on Ranks

Monday, March 23, 1998, 15:42:20

Data source: Data 1 in Notebook

$\begin{array}{lrc}\text { Group } & \text { N } & \text { Missing } \\ \text { C } & 20 & 0 \\ \text { MCQ } & 5 & 0 \\ \text { CR } & 5 & 0 \\ \text { FM-C } & 5 & 0 \\ \text { FM-A7 } & 5 & 0 \\ \text { IG-B } & 5 & 0 \\ \text { PB-A } & 5 & 0 \\ \text { SC } & 5 & 0 \\ \text { FM-A } & 5 & 0 \\ \text { TB } & 5 & 0\end{array}$

\begin{tabular}{lrrr} 
Group & Median & $\mathbf{2 5 \%}$ & \multicolumn{1}{c}{$\mathbf{7 5 \%}$} \\
C & 7.000 & 5.500 & 8.500 \\
MCQ & 4.000 & 2.750 & 5.000 \\
CR & 1.000 & 0.750 & 1.500 \\
FM-C & 3.000 & 1.750 & 3.500 \\
FM-A7 & 10.000 & 9.000 & 12.250 \\
IG-B & 5.000 & 4.500 & 9.000 \\
PB-A & 7.000 & 4.250 & 11.250 \\
SC & 4.000 & 2.500 & 5.750 \\
FM-A & 12.000 & 7.750 & 13.250 \\
TB & 6.000 & 4.000 & 6.500
\end{tabular}

$\mathrm{H}=37.239$ with 9 degrees of freedom. $(\mathrm{P}=<0.001)$

The differences in the median values among the treatment groups are greater than would be expected by chance; there is a statistically significant difference $(P=<0.001)$

To isolate the group or groups that differ from the others use a multiple comparison procedure.

Multiple Comparisons versus Control Group (Dunn's Method) :

$\begin{array}{lcccc}\text { Comparison } & \text { Diff of Ranks } & \mathbf{p} & \mathbf{Q} & \begin{array}{c}\mathbf{P}<0.05 \\ \text { Yes }\end{array} \\ \text { CR vs C } & 33.625 & 10 & 3.571 & \text { No } \\ \text { FM-C vs C } & 25.825 & 9 & 2.743 & \text { No Test Needed } \\ \text { MCQ vs C } & 19.925 & 8 & 2.116 & \text { No Test Needed } \\ \text { FM-A7 vs C } & 16.775 & 7 & 1.782 & \text { No Test Needed } \\ \text { SC vs C } & 16.725 & 6 & 1.776 & \text { No To Test Needed } \\ \text { FM-A vs C } & 15.775 & 5 & 1.675 & \text { No To } \\ \text { TB vs C } & 7.825 & 4 & 0.831 & \text { No Test Needed } \\ \text { IG-B vs C } & 4.025 & 3 & 0.427 & \text { No Test Needed } \\ \text { PB-A vs C } & 0.325 & 2 & 0.0345 & \text { No Test Needed }\end{array}$




\section{Statistical Analyses for Taxa Richness (continued)}

Mann-Whitney Rank Sum Test

Data source: Data 1 in Notebook

$\begin{array}{ll}\text { Normality Test: } & \text { Passed }(P=0.710) \\ \text { Equal Variance Test: } & \text { Passed }(P=0.450)\end{array}$

Group N Missing

$\begin{array}{llr}\text { UTR-8 } & 5 & 0 \\ \text { UTR-C } & 5 & 0\end{array}$

Group Median 25\% $\quad \mathbf{7 5 \%}$

UTR-8 $\quad 8: 000 \quad 6.500 \quad 12.000$

$\begin{array}{llll}\text { UTR-C } & 16.000 & 9.250 & 18.750\end{array}$
Monday, March 23, 1998, 15:45:04

$\mathrm{T}=23.000 \mathrm{n}(\mathrm{small})=5 \mathrm{n}(\mathrm{big})=5 \mathrm{P}($ est. $)=0.403 \mathrm{P}($ exact $)=0.421$

The differences in the median values among the two groups are not great enough to exclude the possibility that the difference is due to random sampling variability; there is not a statistically significant difference $(P=0.421)$ 


\section{Statistical Analyses for Number of EPT Taxa}

One Way Analysis of Variance

Data source: Data 1 in Notebook

Normality Test: $\quad$ Failed $(P=0.004)$

Test execution ended by user request, ANOVA on Ranks begun

Kruskal-Wallis One Way Analysis of Variance on Ranks

Monday, March 23, 1998, 16:06:35

Data source: Data 1 in Notebook

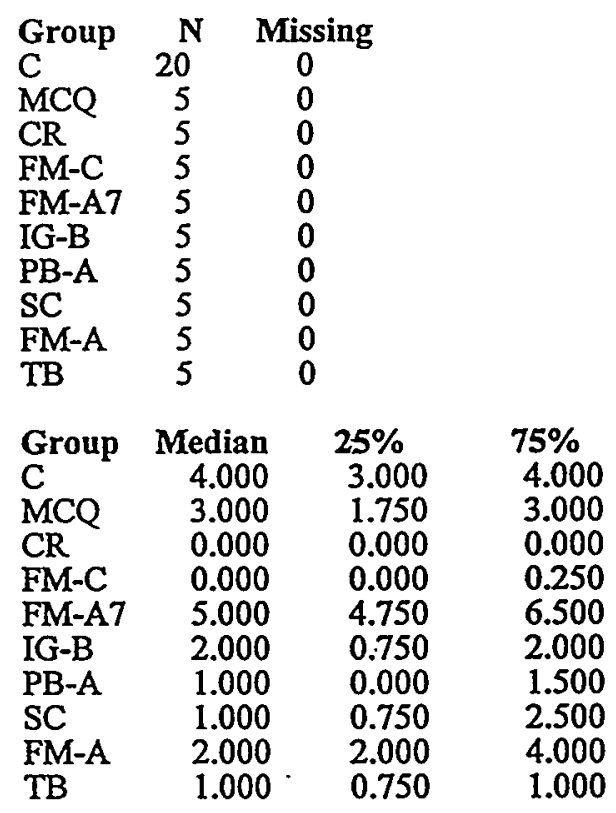

$\mathrm{H}=48.502$ with 9 degrees of freedom. $(\mathrm{P}=<0.001)$

The differences in the median values among the treatment groups are greater than would be expected by chance; there is a statistically significant difference $(P=<0.001)$

To isolate the group or groups that differ from the others use a multiple comparison procedure.

Multiple Comparisons versus Control Group (Dunn's Method) :

$\begin{array}{lrrrr}\text { Comparison } & \text { Diff of Ranks } \mathbf{p} & \mathbf{Q} & \mathbf{P}<0.05 \\ \text { CR vs C } & 40.200 & 10 & 4.315 & \text { Yes } \\ \text { FM-C vs C } & 37.700 & 9 & 4.047 & \text { Yes } \\ \text { TB vs C } & 30.200 & 8 & 3.242 & \text { Yes } \\ \text { PB-A vs C } & 28.500 & 7 & 3.059 & \text { Yes } \\ \text { IG-B vs C } & 23.600 & 6 & 2.533 & \text { No } \\ \text { SC vs C } & 21.700 & 5 & 2.329 & \text { No Test Needed } \\ \text { MCQ vs C } & 12.900 & 4 & 1.385 & \text { No Test Needed } \\ \text { FM-A7 vs C } & 12.200 & 3 & 1.310 & \text { No Test Needed } \\ \text { FM-A vs C } & 8.500 & 2 & 0.912 & \text { No Test Needed }\end{array}$




\section{Statistical Analyses for Number of EPT Taxa (continued)}

t-test

Normality Test:

Passed $(P=0.273)$

Equal Variance Test: Passed $(P=0.966)$

Group N Missing

$\begin{array}{lll}\text { UTR-8 } & 5 & 0 \\ \text { UTR-C } & 5 & 0\end{array}$

Group Mean Std Dev SEM

$\begin{array}{lrrr}\text { UTR-8 } & 6.000 & 3.674 & 1.643\end{array}$

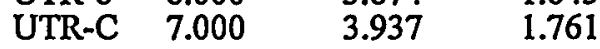

Difference $\quad-1.000$

$t=-0.415$ with 8 degrees of freedom. $(P=0.689)$

95 percent confidence interval for difference of means: -6.554 to 4.554

The difference in the mean values of the two groups is not great enough to reject the possibility that the difference is due to random sampling variability. There is not a statistically significant difference between the i nput groups $(P=0.689)$.

Power of performed test with alpha $=0.050: 0.050$

The power of the performed test $(0.050)$ is below the desired power of 0.800 .

You should interpret the negative findings cautiously. 


\section{Statistical Analyses for North Carolina Biotic Index (NCBI)}

One Way Analysis of Variance

Data source: Data 1 in Notebook

Normality Test: $\quad$ Passed $(P=0.052)$

Equal Variance Test: Failed $(P=0.002)$

Test execution ended by user request, ANOVA on Ranks begun

Kruskal-Wallis One Way Analysis of Variance on Ranks

Monday, March 23, 1998, 16:29:56

Data source: Data 1 in Notebook

$\begin{array}{lccc}\text { Group } & \text { N } & \text { Missing } & \\ \text { C } & 20 & 0 & \\ \text { MCQ } & 5 & 0 & \\ \text { CR } & 5 & 0 & \\ \text { FM-C } & 5 & 0 & \\ \text { FM-A7 } & 5 & 0 & \\ \text { IG-B } & 5 & 0 & \\ \text { PB-A } & 5 & 0 & \\ \text { SC } & 5 & 0 & \\ \text { FM-A } & 5 & 0 & \\ \text { TB } & 5 & 0 & \\ & & & \\ \text { Group } & \text { Median } & 25 \% & 75 \% \\ \text { C } & 5.055 & 4.735 & 5.525 \\ \text { MCQ } & 5.390 & 5.018 & 5.595 \\ \text { CR } & 8.700 & 8.420 & 9.250 \\ \text { FM-C } & 7.120 & 6.338 & 8.045 \\ \text { FM-A7 } & 6.350 & 6.252 & 6.537 \\ \text { IG-B } & 6.540 & 6.475 & 6.705 \\ \text { PB-A } & 6.720 & 5.902 & 7.033 \\ \text { SC } & 6.020 & 5.150 & 6.423 \\ \text { FM-A } & 6.060 & 5.645 & 6.180 \\ \text { TB } & 6.820 & 5.630 & 7.813\end{array}$

$\mathrm{H}=44.562$ with 9 degrees of freedom. $(\mathrm{P}=<0.001)$

The differences in the median values among the treatment groups are greater than would be expected by chance; there is a statistically significant difference $(P=<0.001)$

To isolate the group or groups that differ from the others use a multiple comparison procedure.

Multiple Comparisons versus Control Group (Dunn's Method) :

$\begin{array}{lrrrr}\text { Comparison } & \text { Diff of Ranks } & \mathbf{p} & \mathbf{Q} & \mathbf{P}<0.05 \\ \text { CR vs C } & 47.400 & 10 & 5.014 & \text { Yes } \\ \text { FM-C vs C } & 34.600 & 9 & 3.660 & \text { Yes } \\ \text { IG-B vs C } & 31.600 & 8 & 3.343 & \text { Yes } \\ \text { PB-A vs C } & 29.100 & 7 & 3.078 & \text { Yes } \\ \text { FM-A7 vs C } & 27.700 & 6 & 2.930 & \text { Yes } \\ \text { TB vs C } & 27.300 & 5 & 2.888 & \text { Yes } \\ \text { FM-A vs C } & 18.500 & 4 & 1.957 & \text { No } \\ \text { SC vs C } & 15.800 & 3 & 1.671 & \text { No Test Needed }\end{array}$




\section{Statistical Analyses for North Carolina Biotic Index (NCBI) (continued)}

Mann-Whitney Rank Sum Test

Monday, March 23, 1998, 16:37:27

Data source: Data 1 in Notebook

Normality Test:

Passed $(P=0.622)$

Equal Variance Test: Passed $\quad(P=0.919)$

$\begin{array}{ccc}\text { Group } & \text { N } & \text { Missing } \\ \text { UTR-8 } & 5 & 0 \\ \text { UTR-C } & 5 & 0\end{array}$

Group Median 25\% $75 \%$.

$\begin{array}{llll}\text { UTR-8 } & 4.040 & 2.942 & 4.353\end{array}$

UTR-C $\quad 4.570 \quad 4.195 \quad 5.652$

The differences in the median values among the two groups are not great enough to exclude the possibility that the difference is due to random sampling variability; there is not a statistically significant difference $(P=0.151)$ 


\section{APPENDIX B}

\section{Macroinvertebrate Data}


Appendix Table B-1. Species List, Hester-Dendy Multiplate Samplers

Sitewide Study

5 Nov. -8 Dec 1997

\begin{tabular}{|c|c|c|c|c|c|c|c|c|c|c|c|c|c|c|c|c|c|}
\hline \multirow[b]{4}{*}{ ORDER EPHEMEROFTERA (maytics) } & & \multicolumn{16}{|c|}{ Site / $/$ of Organisms } \\
\hline & & \multicolumn{6}{|c|}{ Upper Three Runs Croek System } & \multicolumn{4}{|c|}{ Four Mile Braxch System } & \multicolumn{4}{|c|}{ Pea Branch System } & \multicolumn{2}{|c|}{ Stecl C. System } \\
\hline & & Tims & Wall & MCQ & Crouch & U3R & U3R & FMB & FMB & FMB & FMB & Pen & Pea & Ind Gr. & Pen & Stoed & Mejers \\
\hline & Expc: & Site 1 & Site 4 & Sites & Sitc 6 & Sitc 3 & Site 2 & Site 7 & Site 8 & Site 9 & Site 16 & Site 10 & Site 11 & Site 12 & Site 13 & Site 14 & Site 15 \\
\hline Aoentrella anspla & $\mathbf{N}$ & 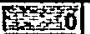 & 0 & 0 & 0 & 0 & 1 & 0 & of & 0 & 0 & of & 0 & o. & 0 & of & 0 \\
\hline Boetis sp. & $\mathbf{N}$ & 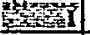 & of & of & of & of & of & of & of & of & of & of & of & of & 1 & of & 0 \\
\hline Boets fritercaloris & $\mathbf{N}$ & 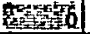 & 0 & 0 & o] & 0 & 2 & of & o) & 12. & 0 & 0 & 1 & 0 & 0 & 1 & 0 \\
\hline Ephemerella (munamire /danorged) & $\mathbf{N}$ & 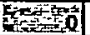 & 0 & 0 & 0 & 0 & 0 & 0 & 0) & 0 & 0 & 0 & 6 & 0 & 0 & of & 1 \\
\hline Exuglophella Ammature/damaged) & $\mathbf{N}$ & 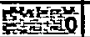 & 1 & 0 & 0 & 0 & 1) & of & 0 & 0 & 0 & of & 0 & 0 & $\ddot{0}$ & 0) & $\overrightarrow{0}$ \\
\hline Euglophella doris & $\mathbf{N}$ & Iris & 0 & 0 & of & 0 & 0 & 0 & 0 & 0 & 14 & of & 0 & 0 & 0 & 0 & 0 \\
\hline Habrophlebla Wbrars & $N$ & 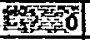 & 0 & 0 & of & 1 & 0 & 0 & 0 & 0 & 0 & of & 0 & 0 & of & 0 & 0 \\
\hline Heptagenta & $\mathbf{N}$ & 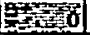 & 0 & 0 & of & $\mathbf{0}$ & s. & 0) & 0 & 0 & 0 & 0) & 0 & 0 & 0 & 0 & 0 \\
\hline Leplophlebla & $\mathrm{N}$ & 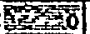 & 0 & 0 & 0 & 0 & 0 & 0) & 0 & 0 & 0 & 3 & 0 & 0 & of & 0 & $\overline{0}$ \\
\hline Paraleptophlebla & $\mathbf{N}$ & 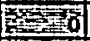 & 2 & $\overline{0}$ & 0 & 0 & 0 & 0 & 0 & 0 & 0 & 0 & 0 & 1 & 0 & 0 & 0 \\
\hline 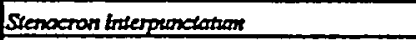 & $\mathbf{N}$ & 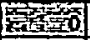 & 0 & 0 & of & 0 & 0 & 0 & 0 & 0 & 0 & 9 & 0 & 0 & 0 & 0 & 0 \\
\hline SSenonema modestumtantithoe & $\mathbf{N}$ & Fin & 53 & 31 & of & 8 & 14 & of & 0 & 22 & 53 & 58 & 62 & 25 & 7 & 22) & 22 \\
\hline
\end{tabular}

\begin{tabular}{|c|c|c|c|c|c|c|c|c|c|c|c|c|c|c|c|c|c|}
\hline ORDER PLECORTERA (stonentis) & Fisa & Sirtin: & risten & Sintas & 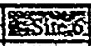 & $\sqrt{B S_{\text {SiE }}}$ & Sisites & Sitax & 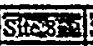 & Siters: & Sirilg & situstan & Stratin & Sirailat: & Statis & Sitand & Sitensis \\
\hline Acronecurala obmomis & $\boldsymbol{N}$ & gaxina & 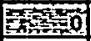 & 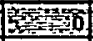 & XYp & intin & 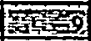 & 0 & of & of & 0 & of & of & of & 0 & 0 & 0 \\
\hline Acraneturla becorlas & $\mathbf{N}$ & 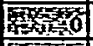 & 0 & 0 & 0 & 10 & 0 & of & of & of & 0 & of & of & of & 0 & 요 & 0 \\
\hline deronesola mela & $\mathbf{N}$ & Es & 0 & 0 & 0 & 0 & 1 & 0 & of & 0 & 0 & 0 & of & 0 & 0 & 0 & 0 \\
\hline Allocogonta & $\mathbf{N}$ & 60 & 19 & 3 & 0 & 0 & 4 & of & 1 & of & 0 & 14 & 9 & 0 & 0 & 0 & 11 \\
\hline Clloperla cllo & $\mathbf{N}$ & 20150 & 2 & 0 & 0 & 0 & 0 & of & of & of & 0 & 1 & of & 0 & 0 & 2 & 4 \\
\hline 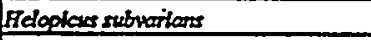 & $\mathrm{N}$ & 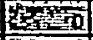 & 0 & 0 & 0 & 2 & 0 & 0 & 0 & of & 0 & of & of & of & 0 & 0 & 0 \\
\hline Looperda dicala & $\mathbf{N}$ & 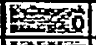 & 0 & 0 & 0 & 0 & 14 & 요 & of & of & 0 & 0 & of & 0 & 0 & 0 & 0 \\
\hline Lsoperia sp & $N$ & tofes & 0 & of & 0 & 4 & 0 & 0 & of & of & 0 & 0 & of & 0 & 0 & 0 & 0 \\
\hline Paralesuctra sara & $\boldsymbol{N}$ & 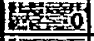 & 0 & 0 & 0 & 0 & 0 & 0 & of & of & 1 & 0 & of & of & 0 & 0 & $\underline{0}$ \\
\hline Paragnetina fumosa & $\mathbf{N}$ & | & 0 & 0 & 0 & 4 & 3 & 0 & of & 1) & 0 & 0 & 0 & 0 & 0 & 0 & 0 \\
\hline Perlestaplocida & $\mathrm{N}$ & BPan & 1 & 1 & 0 & 3 & 3 & of & of & of & 0 & 0 & 5 & of & 0 & 0 & $\underline{0}$ \\
\hline Perilnella cobore & $N$ & Es & 0 & 0 & 요 & 0 & 0 & 의 & of & 0 & 0 & 1 & of & of & 0 & 0 & 1 \\
\hline Plemonarys & $N$ & Fisul| & $\underline{0}$ & 0 & 0 & $\underline{0}$ & 3 & 의 & 요 & 0 & 0 & 0 & of & of & 0 & 0 & $\underline{0}$ \\
\hline Toartoptengx melegut & $\mathbf{N}$ & 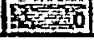 & 1 & 0 & 0 & 4 & 1 & of & 0 & 8 & 0 & 1 & 15 & of & 0 & 13 & 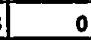 \\
\hline
\end{tabular}




\section{Appendix Table B-1. Species List, Hester-Dendy Multiplate Samplers}

Westinghouse Savannah River Company

Sitewide Study

5 Nov. - 8 Dec 1997

\begin{tabular}{|c|c|c|c|c|c|c|c|c|c|c|c|c|c|c|c|c|c|}
\hline \multirow{2}{*}{ ORDER TRRCHOPTERA (caddisflies) } & & \multicolumn{6}{|c|}{ Upper Three Runs Creek System } & \multicolumn{4}{|c|}{ Four Mile Branch System } & \multicolumn{4}{|c|}{ Pen Branch System } & \multicolumn{2}{|c|}{ Steel C. System } \\
\hline & 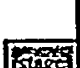 & \begin{tabular}{|l|} 
Tins \\
Site 1
\end{tabular} & Mill & \begin{tabular}{l|}
$M 0 Q$ \\
Sites
\end{tabular} & $\begin{array}{c}\text { Crouch } \\
\text { Site } 6\end{array}$ & $\begin{array}{l}\text { U3R } \\
\text { Site } 3\end{array}$ & $\begin{array}{l}\text { U3R } \\
\text { Sile2 }\end{array}$ & $\begin{array}{l}\text { FMB } \\
\text { Site ? }\end{array}$ & $\begin{array}{l}\text { FMB } \\
\text { Site }\end{array}$ & $\begin{array}{l}\text { FMB } \\
\text { Site } 9\end{array}$ & $\begin{array}{c}\text { FMB } \\
\text { Sitc } 16\end{array}$ & $\begin{array}{c}\text { Pen } \\
\text { Site } 10\end{array}$ & $\begin{array}{c}\text { Pen } \\
\text { Site } 11\end{array}$ & $\begin{array}{l}\text { Ind. Gr. } \\
\text { Site 12 }\end{array}$ & $\begin{array}{c}\text { Pen } \\
\text { Site } 13\end{array}$ & $\begin{array}{c}\text { Stcel } \\
\text { Site } 14\end{array}$ & $\begin{array}{l}\text { Meyers } \\
\text { Site is }\end{array}$ \\
\hline Bnactucentres chelotus & $\mathrm{L}$ & 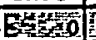 & mat & 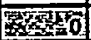 & 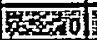 & 1978 & 31 & 0) & of & 0 & of & 0 & 0 & 0 & of & o & $\frac{0}{0}$ \\
\hline Bnoctiocentress numerasus & $\mathbf{L}$ & 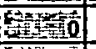 & of & of & of & 0 & 17) & of & of & of & of & of & of & of & of & of & $\underline{0}$ \\
\hline Cenaciea mir nesurgens & $L$ & Ty+a & 1 & of & of & of & 의 & of & of & 의 & of & of & of & of & 의 & of & 0 \\
\hline Cemotha rploata & $L$ & 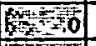 & of & of & of & 0 & 의 & of & of & of & 1 & of & of & 1 & 의 & of & 0 \\
\hline Chexmatopiryche & $L$ & gent & of & 1 & of & 2 & 2 & of & of & 199 & 1 & of & 18 & 1 & 3 & of & 3 \\
\hline Chimarma oterrima & $\mathrm{L}$ & 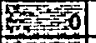 & of & of & of & of & 0 & of & of & 4 & 의 & of & of & 요 & of & of & 0 \\
\hline Diplectrona modesta & $\mathbf{L}$ & 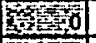 & of & 0 & of & 1 & of & of & of & of & of & of & of & of & of & of & 0 \\
\hline Hutroporyche bettenl & $L$ & 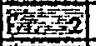 & of & 요 & of & 0 & 0 & of & of & 6 & of & of & of & 의 & of & .0 & 0 \\
\hline Hithropeschic ellseama & $\mathbf{L}$ & 150 & of & 0 & of & 6 & of & of & of & of & of & of & of & of & of & of & 0 \\
\hline Hudroponche ventalaris & L & 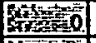 & of & 0 & of & o & of & of & of & of & 2 & of & of & 0 & a. & of & 은 \\
\hline type diversea & $L$ & 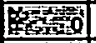 & 1 & 1 & of & of & 0 & of & a) & 2 & of & of & of & of & 의 & of & 1 \\
\hline Macrosema nr. nusticum & $L$ & 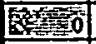 & of & 의 & 요 & 1 & 1 & of & of & of & of & of & of & of & of & 0 & 0 \\
\hline Ongechina & $\mathbf{L}$ & Fin & of & of & of & 0 & 0 & of & of & of & .1) & of & of & $=0$ & of & of & 0 \\
\hline Pananxettophiolax & $\mathbf{L}$ & 8xis & 3 & of & 요 & $\underline{0}$ & 의 & of & of & of & of & of & of & of & of & of & 0 \\
\hline Phylocentropus & $L$ & 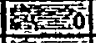 & 의 & 이 & of & 2 & 0 & of & of & of & of & of & 의 & of & 0 & of & 0 \\
\hline Triacnodes & L & (1) & 0 & 0 & of & 0 & 0 & 0 & of & 1 & 의 & 01 & 의 & of & 이 & of & 0 \\
\hline
\end{tabular}

\begin{tabular}{|c|c|c|c|c|c|c|c|c|c|c|c|c|c|c|c|c|c|}
\hline & stat & Esitin & Sosinest & Sistess & Sxiffes & Istas & Estos & Fing & Fichs & 8 & Sinfib: & sina & Fitenis & Siterion & 8 & Strosist & Sileis \\
\hline Arsta sectula & $N$ & Fx+0 & 0 & 0 & 1 & 0 & of & 0 & 0 & 0 & of & 0 & 0) & of & 0 & of & 0 \\
\hline Ardatabialls & $N$ & $x=0$ & 0) & 0 & 0 & of & of & 0 & 0 & of & of & 2 & of & of & 0 & of & 0 \\
\hline Boyerla vinasa & $N$ & 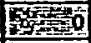 & 1 & 0 & 요 & 1 & of & of & of & of & 요 & 0 & 요 & of & 0 & 1 & 0 \\
\hline Colopheryx dimbitiota & $N$ & 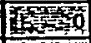 & - & 0 & 0 & 0) & 의 & of & 1 & 의 & 요 & 0 & 이 & 의 & 0 & 의 & 0 \\
\hline Eplitreca (Eploondulla) & $\mathbf{N}$ & 60 & 0 & 0 & 0 & 0 & of & of & of & of & 의 & 0 & of & 1 & 0 & of & 의 \\
\hline Enylinactiplax commata & $\mathbf{N}$ & XXs & 0 & 0 & 0 & 0 & of & of & of & of & 요 & 0 & 0 & 1 & 0 & of & 5 \\
\hline Enollogma sp & $\mathbf{N}$ & Fis & 0 & 0 & 1 & 0 & & 이 & of & 0 & 11 & 0 & 0 & ol & 3 & 0 & 0 \\
\hline
\end{tabular}

\begin{tabular}{|c|c|c|c|c|c|c|c|c|c|c|c|c|c|c|c|c|c|}
\hline 0 & 5 & Silai & PStat & Sistrs & 8 sitte 6 & 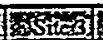 & ISten & 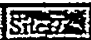 & $\mathrm{S}^{2} \mathrm{x}$ & $5 \sin$ & Sitaik & Silexo9 & Sitem & Sifing & Sicin & Sitelita & Storis \\
\hline $\cos x$ & L & 4 & 2 & 1 & 0 & of & 0 & 0 & $\underline{0}$ & 1 & 1 & 의 & 0 & 의 & & 1 & 은 \\
\hline Migrorla serticomis & $\bar{L}$ & 618 & 1 & 1 & 0 & 2 & 0 & 0 & 0 & 0 & $\overline{0}$ & 0 & 0 & 0 & $\overline{0}$ & 0 & (0) \\
\hline
\end{tabular}

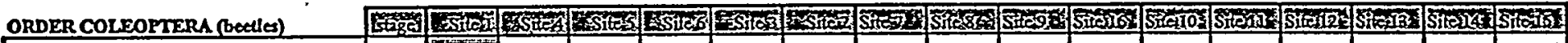

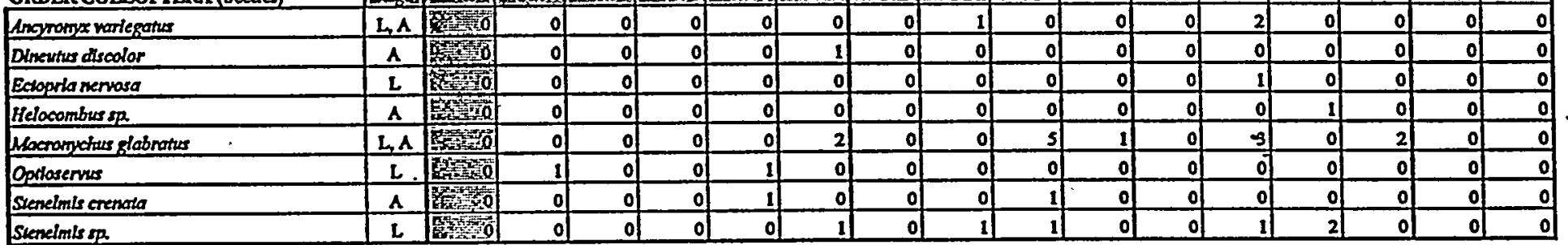




\section{Appendix Table B-1. Species List, Hester-Dendy Multiplate Samplers}

Westinghouse Savannah River Company

Sitewide Study

5 Nor. -8 Dec 1997

\begin{tabular}{|c|c|c|c|c|c|c|c|c|c|c|c|c|c|c|c|c|c|}
\hline \multirow[b]{2}{*}{ ORDER DIFTERA - other than midge } & & \multicolumn{6}{|c|}{ Upper Three Rems Creck System } & \multicolumn{4}{|c|}{ Four Mile Branch System } & \multicolumn{4}{|c|}{ Pen Brench System } & \multicolumn{2}{|c|}{ Stecl Cr. System } \\
\hline & 5028 & $\begin{array}{l}\text { Tims } \\
\text { Site 1 }\end{array}$ & $\begin{array}{l}\text { Mill } \\
\text { Site } 1\end{array}$ & $\begin{array}{l}\text { MoQ } \\
\text { Sites }\end{array}$ & $\begin{array}{l}\text { Croseh } \\
\text { Site } 6\end{array}$ & \begin{tabular}{|c|} 
U3R \\
Site 3
\end{tabular} & $\begin{array}{l}\text { U3R } \\
\text { Site } 2\end{array}$ & \begin{tabular}{|l|} 
FMB \\
Site 7
\end{tabular} & \begin{tabular}{|l|} 
FMB \\
Site 8
\end{tabular} & \begin{tabular}{|l|} 
FMB \\
Site 9
\end{tabular} & \begin{tabular}{|c} 
FMB \\
Site 16
\end{tabular} & \begin{tabular}{|c|} 
Pen \\
Site 10 \\
\end{tabular} & \begin{tabular}{|c|} 
Pen \\
Site II
\end{tabular} & $\mid \begin{array}{l}\text { Ind. Gr. } \\
\text { Site } 12\end{array}$ & \begin{tabular}{|c|} 
Pen \\
Site 13
\end{tabular} & \begin{tabular}{|c|} 
Stecl \\
Site 14
\end{tabular} & $\begin{array}{l}\text { Meyers } \\
\text { Sile-15 }\end{array}$ \\
\hline Cherts lantha & $\mathrm{L}$ & 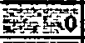 & $\mathrm{g}$ & $\theta$ & o & $\underline{0}$ & 7 & 0 & 0 & 0 & 0 & 0 & & & & 0 & \\
\hline Hemerodiomla & $\mathbf{L}$ & Fits & ic & 7 & $\stackrel{0}{-}$ & $\underline{0}$ & 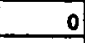 & 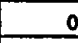 & $\underline{0}$ & 1 & $\underline{0}$ & of & & o] & $\underline{0}$ & of & \\
\hline Ephytridec & $\mathbf{L}$ & 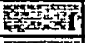 & c & o & $\underline{0}$ & 0 & 0 & o & $\stackrel{0}{0}$ & $\underline{0}$ & $\underline{0}$ & 의 & $\underline{0}$ & ? & $\underline{0}$ & of & \\
\hline 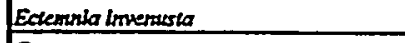 & $\mathbf{L}$ & 50 & s & o & 0 & 5 & $\underline{0}$ & o & $\underline{0}$ & $\underline{0}$ & $\underline{0}$ & 0 & 0 & of & $\underline{0}$ & of & \\
\hline Consopssp & $\mathbf{L}$ & 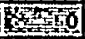 & c & 0 & 0 & 0 & 0 & 1 & 0 & 0 & 0 & 0 & 0 & 0 & $\overline{0}$ & 0 & 0 \\
\hline Sundhum villatum complex & $\mathbf{L}$ & 5 & c & 0 & $\underline{0}$ & $\underline{0}$ & 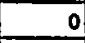 & $\underline{0}$ & $\underline{0}$ & 1 & $\underline{0}$ & 0 & $\underline{0}$ & of & $\overline{0}$ & 0 & \\
\hline 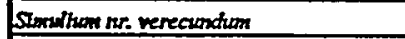 & $\mathbf{L}$ & 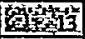 & s & ? & $\underline{0}$ & $\underline{0}$ & - & 0 & $\underline{0}$ & 3 & o & 7 & g & of & $\overline{7}$ & 의 & 0 \\
\hline Sinsulfum ruberosem complex & $\mathbf{L}$ & 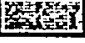 & s & 0 & $\underline{0}$ & 2 & 0 & 0 & 0 & 17 & 0 & 0 & 0 & 의 & $\overline{0}$ & I] & \\
\hline
\end{tabular}

\begin{tabular}{|c|c|c|c|c|c|c|c|c|c|c|c|c|c|c|c|c|c|}
\hline ORDER DIPTERA - (Tanypodinae) & Es: & Suicil & sitax & 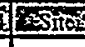 & 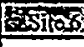 & 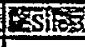 & SEStite & Stiten & Ste- & 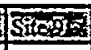 & Ffreal6 & Sicion & 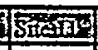 & इFin & $\sqrt{\overline{s i c} \text { is }}$ & Sitcial & 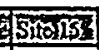 \\
\hline Ablabesmyta mollocts & L & 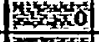 & s & o & $\underline{0}$ & $\underline{0}$ & 의 & 0 & 0 & $\underline{0}$ & 1 & & & s) & & & 0 \\
\hline 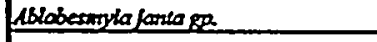 & $\boldsymbol{L}$ & Exys & c & ] & $\underline{0}$ & - & 0 & 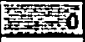 & $\underline{0}$ & $\underline{0}$ & 0 & 의 & 0 & of & & of & 으 \\
\hline Conchopelopia & $L$ & Fin & 1 & 1 & 1 & 1 & 0 & 0 & 1 & $\underline{0}$ & 1 & 4 & 1 & 1 & $\underline{0}$ & of & 5 \\
\hline Lobruacinla pllosella & L & 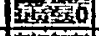 & I & $\underline{0}$ & 0 & 0 & 0 & o & $\stackrel{0}{-}$ & $\underline{0}$ & o & 의 & 0 & of & $\underline{\mathbf{0}}$ & 1 & 0 \\
\hline Paromeriva & $\mathbf{L}$ & 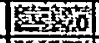 & . & ] & $\underline{0}$ & $\underline{0}$ & 0 & 0 & $\underline{0}$ & $\underline{0}$ & $\underline{0}$ & of & 0 & of & 0 & 0 & 0 \\
\hline mellimgla & $L$ & Ese & c & & & & & & & & & & & & & & \\
\hline
\end{tabular}

\begin{tabular}{|c|c|c|c|c|c|c|c|c|c|c|c|c|c|c|c|c|c|}
\hline ORDER DIPTERA - (Orthocled dinRe) & Fis & 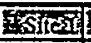 & Sitcen & sition & 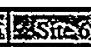 & 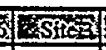 & 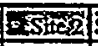 & 3iend & 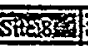 & 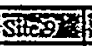 & 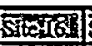 & sifeitios & 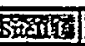 & I5icion & Sintion & 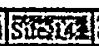 & Siters \\
\hline Britlia Rentifions & L & Dis & of & 0 & 0 & .0 & 2 & of & 0 & of & 0 & of & of & 0 & of & i) & 0 \\
\hline Contromeare & $\underline{L}$ & 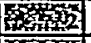 & of & 0 & $\underline{0}$ & of & 1 & of $1-1-1-1$ & of & of & 20 & of & 0 & 2 & i. & of & 0 \\
\hline 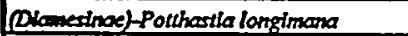 & $\mathbf{L}$ & 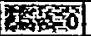 & o] & 0 & $\mathbf{0}$ & of & 0 & 0 & 0 & of & of & of & 0 & 1) & of & 0 & 0 \\
\hline Crloolopers bleinctus & $\mathbf{L}$ & S25 & of & 0 & $\underline{0}$ & of & 0 & of & of & s) & of & of & 0 & of & of & 0 & $=0$ \\
\hline Exublefertella daripernits ga. & $\underline{L}$ & 8 & of & - & $\underline{0}$ & of & 1 & of & of & of & of & of & o & of & 0 & 의 & .0 \\
\hline Mefferatios dix & $L$ & 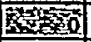 & of & 0 & $\underline{0}$ & of & of & 0 & 7 & of & 0 & 0 & 0 & 0 & of & 0 & 0 \\
\hline Nenododitur & $\mathbf{L}$ & 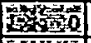 & 1 & 1 & $\underline{\mathbf{0}}$ & of & of & of & of & of & 0 & of & & of & 0 & 0 & 0 \\
\hline Bjustoboemas: & $\underline{L}$ & 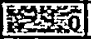 & of & 0 & $\underline{0}$ & of & of & of & 7 & of & 1 & of & 0 & a) & 1 & 0 & - \\
\hline Orthododius nr. oarlaters & $\mathbf{L}$ & 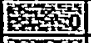 & 0 & $\underline{0}$ & $\underline{0}$ & 0 & 7 & of & 0 & of & of & of & 0 & of & 0 & 0 & 0 \\
\hline Orethodadius sp. & $\mathbf{L}$ & Bations & 0 & 의 & $\underline{0}$ & 0 & of & of & 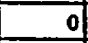 & of & 4 & of & 0 & of & 0 & 0 & $\mathbf{0}$ \\
\hline Orthododius mr. arrirectens & $\mathbf{L}$ & 58 & 0 & 0 & $\underline{0}$ & of & of & of & 0 & 0 & 0 & of & 1 & 0 & 0 & & \\
\hline 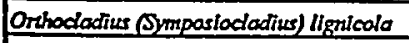 & L & 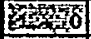 & of & 의 & $\underline{0}$ & of & of & of & 0 & of & of & of & 1 & of & & 0 & $\underline{0}$ \\
\hline Orthododius obumbrotus & $\mathbf{L}$ & 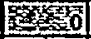 & 0 & 은 & $\underline{0}$ & of & of & of & of & of & 0 & of & 2 & of & & 0 & \\
\hline Parablefferdella & $\mathbf{L}$ & 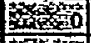 & 0 & 0 & of & of & 2 & of & of & i) & 36 & of & 0 & 2 & 8 & 3 & $\underline{0}$ \\
\hline 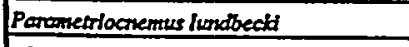 & $\overline{L, P}$ & 5 & 1 & 3 & $\underline{0}$ & of & g & of & of & 3. & 11 & of & 6 & 21 & & 1 & 37 \\
\hline Rheocricolopus roboch & $\mathbf{L}$ & 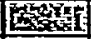 & 0 & 1 & 0 & 2 & 65 & of & 0 & 1 & 6 & o) & 5 & of & 4 & $\overline{0}$ & \\
\hline Spoorthod lotius sembitirens & $\mathbf{L}$ & Se & $\underline{0}$ & 0 & 0 & of & 1 & of & of & of & o & of & & 0 & 0 & $\underline{0}$ & $\underline{0}$ \\
\hline Thiencenarnilelta xerra ga & $\mathbf{L}$ & 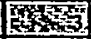 & $\underline{0}$ & 1 & $\underline{0}$ & of & 1 & of & of & of & 0 & of & o & of & 0 & 0 & tis \\
\hline 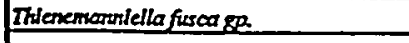 & $\mathbf{L}$ & 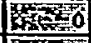 & 0 & 0 & $\underline{0}$ & of & of & of & 7 & of & 0 & of & 0 & of & 0 & of & \\
\hline Ineterta paruencea ge. & $\mathbf{L}$ & Fis & $\underline{0}$ & 0 & $\underline{0}$ & of & 1 & 0 & 의 & $3 t$ & $\underline{0}$ & of & $\underline{0}$ & of & $\underline{0}$ & 1 & It \\
\hline Thelenla discoloripers gp. & L & 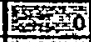 & 0 & 0 & $\underline{0}$ & 1 & 6 & 1 & 0 & of & 0 & of & 0 & of & 0 & o) & \\
\hline Unntella multhivirga & $\mathbf{L}$ & 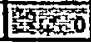 & 0 & 0 & $\underline{0}$ & 의 & of & 0 & 0 & 0 & 0 & of & 0 & o) & 0 & ot & \\
\hline
\end{tabular}

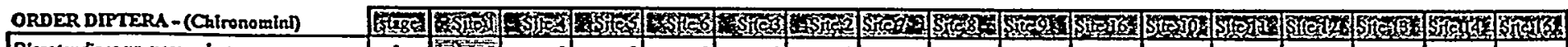

\begin{tabular}{|c|c|c|c|c|c|c|c|c|c|c|c|c|c|c|c|c|c|}
\hline Ditorolendipes $\mathrm{mr}$, reomodestus & $L$ & 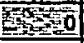 & 0 & 의 & 0 & 0 & 0 & 0 & 0 & s & & of & 0 & 3 & 4 & 0 & 0 \\
\hline Asicontendipes nr. pedellos & $\underline{\mathbf{L}}$ & 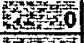 & 7 & 0 & 0 & 0 & of & of & $\underline{0}$ & of & $\underline{0}$ & 22. & 0 & 1 & 0 & of & 의 \\
\hline Maroorendipes or. oudalensts & L & S10 & 0 & 0 & 0 & 2 & 4 & of & $\underline{0}$ & 0 & & 0 & $\underline{0}$ & 0 & $\underline{0}$ & of & 0 \\
\hline Phoenopsectra floutpes & $\mathbf{L}$ & 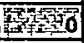 & 1 & 0 & 4 & 0 & 0 & 0 & 1 & 1 & $\underline{0}$ & 0 & 0 & 0 & 1 & 0 & 0 \\
\hline Irbbelos /ucundum & $\mathbf{L}$ & 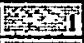 & 0 & 0 & 0 & 0 & 0 & of & $\underline{0}$ & 0 & & 0 & $\underline{0}$ & 35 & 14 & 0 & 0 \\
\hline Polypediluma aviceps & $\underline{L}$ & 780 & 1 & 0 & 0 & 1 & 0 & $\stackrel{0}{-}$ & 1 & 1 & 2 & 0 & 3 & $\underline{0}$ & - & 11 & 47 \\
\hline Polypedilum fallax & $\bar{L}$ & 8 & 0 & 0 & $\mathrm{t}$ & 0 & 0 & 0 & $\underline{0}$ & 0 & & 0 & $\underline{0}$ & $\underline{0}$ & 6 & 0 & 1 \\
\hline Polypedlum aviceps & 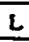 & Ko & 0 & 0 & 0 & 0 & 7 & 0 & 0 & 0 & 0 & 0 & 0 & of & $\frac{3}{3}$ & 0 & 0 \\
\hline Polypedilum Illimoense & $\mathbf{L}$ & $7^{2} 0$ & 0 & 0 & 0 & 0 & 0 & 0 & 0 & 2 & 2 & 0 & 0 & 0 & 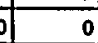 & 0 & 7 \\
\hline Polypedilum follax & $\mathbf{L}$ & strat: & 0 & 0 & 0 & 0 & & 0 & 0 & 0 & & 0 & of & of & & & 0 \\
\hline
\end{tabular}




\section{Appendix Table B-1. Species List, Hester-Dendy Multiplate Samplers \\ Westinghouse Savannah River Company \\ Sitewide Study \\ 5.Nov. - 8 Dec 1997}

\begin{tabular}{|c|c|c|c|c|c|c|c|c|c|c|c|c|c|c|c|c|c|}
\hline \multirow[b]{2}{*}{ ORDER DIPTERA - (Tanytarinin) } & & \multicolumn{6}{|c|}{ Upper Three Runs Creek System } & \multicolumn{4}{|c|}{ Four Mile Branch System } & \multicolumn{4}{|c|}{ Pen Branch System } & \multicolumn{2}{|c|}{ Steel Cr. System } \\
\hline & tives & \begin{tabular}{|l|} 
Tims \\
Site I
\end{tabular} & $\begin{array}{c}\text { Mill } \\
\text { Site } 4\end{array}$ & $\begin{array}{l}\text { MoQ } \\
\text { Sites }\end{array}$ & \begin{tabular}{|l|} 
Crouch \\
Site 6
\end{tabular} & $\begin{array}{c}\text { U3R } \\
\text { Site } 3\end{array}$ & $\begin{array}{c}\text { U3R } \\
\text { Site 2 }\end{array}$ & $\begin{array}{l}\text { FMB } \\
\text { Site } 7\end{array}$ & $\begin{array}{l}\text { EMB } \\
\text { Site } 8\end{array}$ & \begin{tabular}{|l|} 
FMB \\
Site 9
\end{tabular} & \begin{tabular}{|c|} 
FMB \\
Site 16
\end{tabular} & \begin{tabular}{|c|} 
Pen \\
Site 10 \\
\end{tabular} & $\begin{array}{c}\text { Pen } \\
\text { Site } 11\end{array}$ & $\begin{array}{l}\text { Ind Gr. } \\
\text { Site } 12\end{array}$ & \begin{tabular}{|c|} 
Pea \\
Site 13
\end{tabular} & \begin{tabular}{|c|} 
Steel \\
Site 14
\end{tabular} & $\begin{array}{l}\text { Meyers } \\
\text { Site } 15\end{array}$ \\
\hline Panalamplarsus & $\mathrm{L}$ & risa & of & 0 & 0 & of & 1 & 0 & 3 & 0 & of & 0 & 0 & 0 & 0 & 0 & 0 \\
\hline Rheolanylarsus distinctlssimus ga & $\mathbf{L}$ & rin & of & $\underline{0}$ & 0 & 7 & 11 & 0 & 3 & 0 & 22 & 1 & 3 & 1 & 0 & 2 & 4 \\
\hline Tamplarsus & L,P & 13 & of & 0 & 0 & of & of & $\cdot 1$ & 0 & 0 & 16 & 0 & 0 & 1 & 15 & 0 & 18 \\
\hline
\end{tabular}

\begin{tabular}{|c|c|c|c|c|c|c|c|c|c|c|c|c|c|c|c|c|}
\hline PIYLUM ANNEIIDA (worms, leeches) & ExAl & HSich & siticas & esions & Sistex & BSites & Sicestest & Sitcis & Sitects & Stantion & Siloin & Stratin & S1EAR & Silsise & Stonst & Strisis: \\
\hline Lumbricalidec & 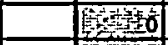 & 0 & 0 & 0 & 의 & 1 & 1 & 0 & 의 & 0 & 0 & 0 & 0 & 0 & 0 & 0 \\
\hline Phydam Nementoda & $y=0$ & 0 & 0 & 0 & of & 1 & 0 & of & of & $\underline{0}$ & 0 & 의 & of & 0 & $\underline{0}$ & 의 \\
\hline Unctrats uncinata & 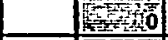 & 0 & 0 & 0 & 요 & $\underline{0}$ & 0 & 2 & o) & 0 & of & 0 & o) & 0 . & 0 & 0 \\
\hline Sylaria fosrularts & E Ext & o & 0 & 0 & 이 & $\underline{0}$ & 0 & of & 0 & of & of & 요 & 1 & 0 & 0 & 0 \\
\hline Nats comments & 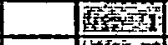 & $\underline{0}$ & $\underline{0}$ & 0 & 0 & $\underline{0}$ & $\underline{0}$ & of & of & 0 & 의 & 0 & of & $\underline{0}$ & $\underline{0}$ & o \\
\hline Tubificidere(w/o cap. 2etec) & 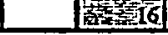 & o & 0 & $\mathbf{0}$ & of & o & 0 & o) & o) & 0 & of & of & of & 0 & $\mathbf{0}$ & 1 \\
\hline
\end{tabular}

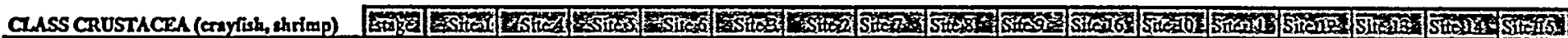

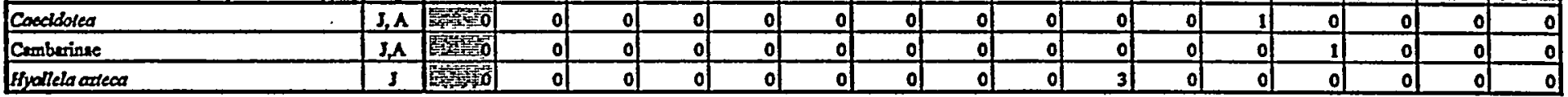

\begin{tabular}{|c|c|c|c|c|c|c|c|c|c|c|c|c|c|c|c|c|c|}
\hline FHYLUM MOLLUSCA (dams, malls) & Ftex & Rsiten & Sisted & Ssites & BSile & LSices & Sositem & Silera & Sices & $5 x=9$ & Sitisice & Stition & Sistige & Stestiz & Sifein & Siratitu & Sirilk \\
\hline Anndeola limasa & mail & 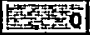 & 0 & $\mathbf{0}$ & $\mathbf{0}$ & 0 & 0 & 0 & $\mathbf{0}$ & 0 & I & 0 & $\mathbf{0}$ & 0 & 1 & of & 0 \\
\hline Corblcula fuminea & dem & 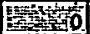 & o) & 0 & 0 & 0 & 0 & 0 & 0 & 0 & 1 & 0 & 1 & 0 & 0 & 0 & $\overline{0}$ \\
\hline Fartista & saril & Existo & 의 & $\underline{\mathbf{0}}$ & o & o & 0 & 1 & $\mathbf{0}$ & o & 1 & 0 & o & of & 0 & 1) & $\mathbf{0}$ \\
\hline Oynouls perrulus & savil & 9.8. & of & $\mathbf{0}$ & $\mathbf{0}$ & $\mathbf{0}$ & 0 & of & $\mathbf{0}$ & 0 & 1 & 0 & o & 0 & 0 & o] & 0 \\
\hline Sphoertum & celem & 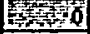 & of & o & $\mathbf{0}$ & $\mathbf{0}$ & 0 & of & 0 & 0 & 0 & 0 & $\underline{0}$ & 0 & 1 & of & 0 \\
\hline Phosella helerostropha & snail & Pry & of & $\mathbf{0}$ & $\mathbf{0}$ & 0 & 0 & 0 & $\mathbf{0}$ & 3 & 0 & 0 & 0 & 1 & 0 & 1 & $\mathbf{0}$ \\
\hline
\end{tabular}

(1)

(1)




\section{Appendix Table B-1. Species List, Hester-Dendy Multiplate Samplers}

Westinghouse Savannah River Company

Sitewide Study

5 Nov. - 8 Dec 1997

\begin{tabular}{|c|c|c|c|c|c|c|c|c|c|c|c|c|c|c|c|c|c|}
\hline \multirow[b]{3}{*}{ ORDER EPHEMEROPTERA (mayntio) } & & \multicolumn{16}{|c|}{ Site/\# of Organisms } \\
\hline & & \multicolumn{6}{|c|}{ Upper Three Runs Creek System } & \multicolumn{4}{|c|}{ Four Mile Branch System } & \multicolumn{4}{|c|}{ Pen Branch System } & \multicolumn{2}{|c|}{ Steel Cr. System } \\
\hline & 5 & $\begin{array}{l}\text { Tums } \\
\text { Site 1 }\end{array}$ & $\begin{array}{l}\text { Mill } \\
\text { Site } 4\end{array}$ & $\begin{array}{l}\text { MoQ } \\
\text { Site } 5\end{array}$ & $\begin{array}{c}\text { Crouch } \\
\text { Site } 6\end{array}$ & $\begin{array}{l}\text { U3R } \\
\text { Site } 3\end{array}$ & $\begin{array}{c}\text { U3R } \\
\text { Site 2 }\end{array}$ & $\begin{array}{l}\text { FMB } \\
\text { Site } 7\end{array}$ & $\begin{array}{l}\text { FMB } \\
\text { Site \& }\end{array}$ & $\begin{array}{l}\text { FMB } \\
\text { site } 9\end{array}$ & \begin{tabular}{|c|} 
FMB \\
Site 16
\end{tabular} & $\begin{array}{c}\text { Pen } \\
\text { Site } 10\end{array}$ & $\begin{array}{c}\text { Pen } \\
\text { Site } 11\end{array}$ & $\begin{array}{l}\text { Ind. Gr. } \\
\text { Site } 12\end{array}$ & $\begin{array}{c}\text { Pen } \\
\text { Site } 13 \\
\end{array}$ & \begin{tabular}{|c|} 
Stod \\
Site 14
\end{tabular} & $\begin{array}{l}\text { Meyers } \\
\text { Sile.15 }\end{array}$ \\
\hline Boetts dublum & $\mathbf{N}$ & 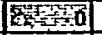 & 0 & of & 의 & 1 & of & 의 & 의 & of & of & of & 의 & of & of & 0 & $\overline{0}$ \\
\hline Boets fromdalls & $\mathbf{N}$ & Existis & 0 & of & of & 1 & of & of & of & 25 & of & of & of & 0 & 1 & 0 & 5 \\
\hline Boetts intercolaris & $\mathbf{N}$ & 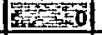 & of & 3 & of & of & of & of & of & 1 & of & a) & 1 & of & 1) & 0 & 1 \\
\hline Boets propingues & $\mathbf{N}$ & 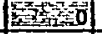 & of & of & of & of & 7 & of & of & 의 & o & of & 의 & 0 & of & 0 & 0 \\
\hline Colliboetis & $\mathbf{N}$ & S & of & 요 & of & of & of & of & of & of & 1 & of & of & 1 & 의 & 0 & 0 \\
\hline Coenis diminula & $\mathbf{N}$ & Eventin & of & of $1 \mathrm{r}(\mathrm{r})$ & 의 & of & of & of & of & of & 0 & of & of & 0 & of & 0 & 0 \\
\hline Ephemenella (mumeture / domoged) & $\mathbf{N}$ & E & of & 0 & of & 의 & of & o & of & 0 & 0 & of & 2 & 0 & of & 0 & 1 \\
\hline Explophella (inmusture/dannoged) & $\mathbf{N}$ & 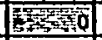 & of & 0 & 0 & 0 & 0 & of & 0 & 0 & 0 & 0 & 0 & 0 & 0 & 0 & 1 \\
\hline Exrylophelle dorts & $\mathbf{N}$ & | & of $1 \mathrm{r}-\mathrm{r} \mathrm{r}$ & of & of & of & of & of & 의 & of & 1 & of & 의 & 0 & o & 0 & 0 \\
\hline Herogenla limbata & $\mathbf{N}$ & L & 3) & 0 & of & 3 & 3 & of & 의 & 0 & 0 & of & 3 & 0 & 0 & 0 & 0 \\
\hline Lopraphlebia & $\mathbf{N}$ & 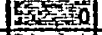 & of $12-1$ & 0 & of $1-3-1$ & of & of & of & of & of & 0 & 14 & of & 0 & 0 & 0 & 0 \\
\hline Neoephentera youmtgl & $\mathbf{N}$ & 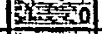 & of & 0 & 의 & 1 & 3) & of & o & of & 0 & of & of & 0 & 1 & 0 & 0 \\
\hline Paraleplophilebla & $\boldsymbol{N}$ & 00 & 4) & 0 & of & 의 & 9] & 의 & 0 & 1 & 0 & of & 1 & 2 & 0 & 0 & 0 \\
\hline Srenacron breerpuncerateon & $\mathbf{N}$ & 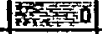 & of & 0 & of & of & of & of & 0 & 0 & 0 & 1 & of & 0 & 0 & 0 & 1 \\
\hline Senonema nodertim/smithor & $\mathbf{N}$ & 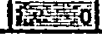 & 5) & 9 & of & 1 & 101 & of & 0 & 4) & 1 & 1) & 4) & 2 & 0 & 1 & 9 \\
\hline
\end{tabular}

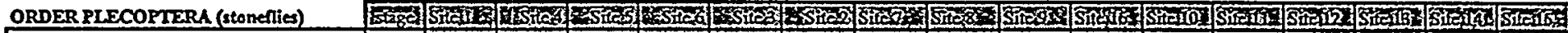

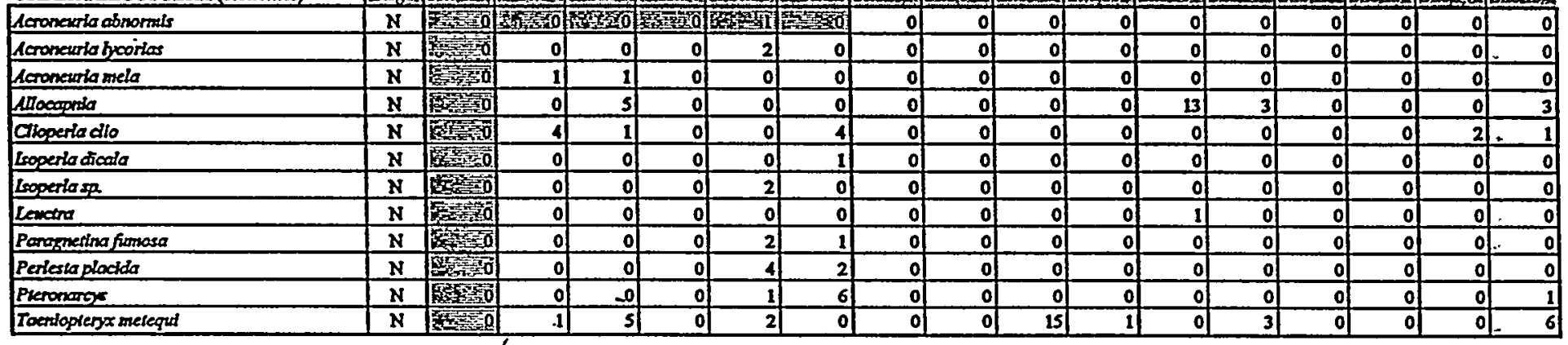




\section{Appendix Table B-2. Species List, Qualitative Sampling of Natural Substrates \\ Westinghouse Savannah River Company \\ Sitewide Study \\ 5 Nov. -8 Dec 1997}

\begin{tabular}{|c|c|c|c|c|c|c|c|c|c|c|c|c|c|c|c|c|c|}
\hline \multirow[b]{3}{*}{ ORDER TRICHOPTERA (caddisfies) } & \multirow[b]{3}{*}{ Ftage } & \multicolumn{16}{|c|}{ Site/H of Organisms } \\
\hline & & \multicolumn{6}{|c|}{ Upper Three Runs Creek System } & \multicolumn{4}{|c|}{ Four Mile Branch System } & \multicolumn{4}{|c|}{ Pea Branch System, } & \multicolumn{2}{|c|}{ Steel C. System } \\
\hline & & $\begin{array}{l}\text { Tims } \\
\text { Site 1 }\end{array}$ & $\begin{array}{l}\text { Mill } \\
\text { Site } 4\end{array}$ & $\begin{array}{c}\text { MoQ } \\
\text { Site } 5\end{array}$ & \begin{tabular}{|c|} 
Crouch \\
Site 6 \\
\end{tabular} & $\begin{array}{l}\text { U3R } \\
\text { Site } 3 \\
\end{array}$ & $\begin{array}{l}\text { U3R } \\
\text { Site 2 }\end{array}$ & $\begin{array}{l}\text { EMB } \\
\text { Site } 7\end{array}$ & $\begin{array}{l}\text { FMB } \\
\text { Site } 8\end{array}$ & $\begin{array}{l}\text { FMB } \\
\text { Site9 }\end{array}$ & $\begin{array}{c}\text { FMB } \\
\text { Site } 16 \\
\end{array}$ & $\begin{array}{c}\text { Pen } \\
\text { Site } 10\end{array}$ & $\begin{array}{c}\text { Pen } \\
\text { Site } 11\end{array}$ & $\begin{array}{l}\text { Ind. Gr. } \\
\text { Site } 12\end{array}$ & $\begin{array}{c}\text { Pen } \\
\text { Site } 13\end{array}$ & \begin{tabular}{|c|} 
Stoed \\
Site 14
\end{tabular} & $\begin{array}{l}\text { Meyers } \\
\text { Site is }\end{array}$ \\
\hline Brachucentris chelatus & L & tons & a & Exan & Patsin & 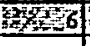 & 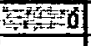 & of & 의 & of & of & of & 0 & of & of & $\begin{array}{l}0 \\
\end{array}$ & 0 \\
\hline Bractycentrus mumerarus & $\mathbf{L}$ & $y^{2}=0$ & of & 의 & 0 & 의 & 17 & of & of & 요 & of & of & 0 & 0 & of & of & 0 \\
\hline Anleacenimopus pymaloldes & $\mathbf{L}$ & 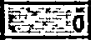 & 1 & 2 & 요 & - & of & of & of & of & 0 & 1 & 0 & o & 0 & 0 & 0 \\
\hline Cemollisa splocta & $L$ & $2=0$ & 요 & 0 & of & 1 & 의 & of & of & of & of & of & of & of & of & of & 0 \\
\hline Cheumatopseche & L & 25 & 0 & 6 & o & 4. & 6) & of & of & 12 & 1) & 3 & 5 & 3 & 1 & 6 & 1 \\
\hline Chimarma alerrima & L & $x_{2}^{2} \leq 0$ & of & 의 & 의 1010 & 의 & 2 & of & of & of & of & of & of & 2 & of & of & 1 \\
\hline Diplectrona modesla & L & $F^{2}=0$ & 0 & 1 & o) & of & 의 & of & of & o] & of & of & of & of & of & o] & 0 \\
\hline Hudroposche bellent & $\mathbf{L}$ & 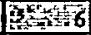 & 0 & 2 & of & 의 & of & of & of & of & 의 & 1 & of & of & of & 4) & 1 \\
\hline Hudropsyche elissontra & $\mathbf{L}$ & Exint & o & of & of & 7 & 41 & of & of & of & of & of & 이 & o] & of & 0 & 0 \\
\hline Hydrospyehesp. 2 & $\mathbf{L}$ & ty & 은 & 의 & of & 인 & 의 & of & 의 & 의 & 의 & . of & of & 0 & 4 & of & 0 \\
\hline Lype diversa & $\mathbf{L}$ & $8=0$ & 0 & 0 & 0 & 0 & 의 & of & of & 0 & 의 & of & 0 & 1 & of & of & 은 \\
\hline Microsema nr, rusticumt & L & 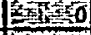 & 0 & of & of & 의 & 1 & of & of & 의 & 의 & 의 & of & of & 의 & of & 0 \\
\hline Neureclipsls & $\mathbf{L}$ & $y=0$ & 의 & of & of & 1 & s) & 의 & 의 & of & 의 & of & 의 & of & 의 & 의 & 0 \\
\hline Oxyethina & $\mathbf{L}$ & 5 & 의 & of & of & of & of & of & of & of & 1 & of & 의 & 1 & 의 & 의 & 0 \\
\hline Paramietlophylax & $\mathbf{L}$ & $y=0$ & 0 & of & of & of & 1 & of & of & of & of & of & of & of & of & of & 0 \\
\hline Phylocentropuss & $\mathbf{L}$ & 50 & 1 & 9 & 요 & 0 & 1 & of & of & of & 의 & of & of & of & 의 & of & 1 \\
\hline Psllotrelasp. & $\mathbf{L}$ & Sino & 0 & 1 & 0 & 의 & 의 & of & o & 0 & of & of & of & of & 의 & of & 0 \\
\hline Pullastonts & L & 50 & $\underline{0}$ & 의 & 의 & 0 & of & of & I) & of & of & of & of & of & 의 & of & 2 \\
\hline Bycroposychic luculenta/sonso & L & $10 x-0$ & 0 & 0 & 0 & 1 & 1 & 요 & 의 & 0 & 요 & 2 & of & 이 & 2. & of & $\mathbf{0}$ \\
\hline Pyenoporyche ip. 2 (w/ 3 slded cosse) & $\mathbf{L}$ & 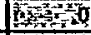 & o & 의 & 의 & 0 & 의 & of & 의 & 0 & 의 & 의 & 의 & 의 & 요 & of & 2 \\
\hline Nectopsyctie & $\mathbf{L}$ & $x+0$ & o & 의 & 의 & 0 & 의 & 의 & 의 & 의 & 의 & of $1-3-1$ & 의 & 요 & 의 & 1 & - \\
\hline nhaenodes & L & 80 & 1 & 0 & 0 & 0 & 5 & of & 의 & 0 & 0 & 요 & 0 & 0 & 1 & 1 & 1 \\
\hline
\end{tabular}

\begin{tabular}{|c|c|c|c|c|c|c|c|c|c|c|c|c|c|c|c|c|c|}
\hline ORDER ODONATA (dragonflies) & Ease & 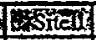 & pinteq & Wosing & Fistex & Sosing & SISES & Sitazy & Ste8 8 & Sites & Sifent 6 & Fitaito: & STESII & STEAR & Sits & Siforite & Stis \\
\hline Angla sedula & $\mathbf{N}$ & Sixts & 의 & 0 & 0 & 의 & 의 & of & 의 & of & 1 & of & of & of & of & 의 & of \\
\hline Anglasp & $\mathbf{N}$ & 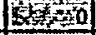 & 0 & 0 & o & 1 & of & of & of & 1 & 의 & of & 2 & 0 & 1 & 0 & 의 \\
\hline Boyerta whosa & $\mathbf{N}$ & 10 & 1 & 2 & o & 3 & 2 & 의 & of & of & I) & of & 1 & 1 & of & 7 & o \\
\hline Coloplengx dimidiata & $\mathbf{N}$ & 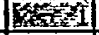 & 1 & 4 & $\underline{0}$ & 2 & 2 & 의 & 1 & 2 & 1 & 1 & 2 & 은 & 1 & 9 & 1 \\
\hline Condulegrosier sp. & $\boldsymbol{N}$ & 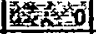 & 1 & 1 & 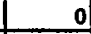 & 0 & of & of & 2 & of & of & of & of & 0 & 이 & 0 & 의 \\
\hline Contulegersier maculata & $\mathbf{N}$ & 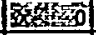 & 0 & - & $\underline{0}$ & 0 & of & of & 0 & 요 & 0 & of & 0 & 0 & 0 & 2 & 7 \\
\hline Endlogma nr. divogans & $\mathrm{N}$ & 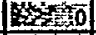 & 0 & $\underline{0}$ & - & 0 & 0 & of & 0 & of & 0 & 7 & 0 & 0 & 0 & 0 & 0 \\
\hline Enallogrima sp. & $\mathbf{N}$ & 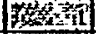 & 1 & $\underline{0}$ & $\underline{0}$ & 3 & 0 & o & 1 & 2 & 2 & of & of & 0 & 1 & 2 & 4 \\
\hline Gomplus rogersl & $\mathbf{N}$ & $3 x=0$ & 3 & 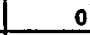 & $\underline{0}$ & 0 & of & of & 0 & of & 0 & of & of & $\underline{0}$ & 0 & 0 & 의 \\
\hline Gomphess Itwidus & $\mathbf{N}$ & Fan & 3 & 0 & $\underline{0}$ & o & 1 & o & of & of & 0 & 2 & 8 & $\underline{0}$ & 0 & 1 & 1 \\
\hline Gomphus (Styurus) nolatus & $\mathbf{N}$ & $5 \times 2 \times 0$ & 0 & 1 & $\underline{0}$ & 2 & 0 & 0 & of & 0 & $\underline{0}$ & of & of & 0 & $\underline{0}$ & $\underline{0}$ & 0 \\
\hline Hagenlus brevisolus & $\mathbf{N}$ & 秐 & 0 & $\mathbf{0}$ & $\underline{0}$ & $\underline{0}$ & of & of & of & 의 & 0 & of & of & $\mathbf{0}$ & 0 & 1 & 의 \\
\hline Ubellula & $\mathbf{N}$ & 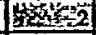 & 0 & 0 & 0 & 0 & 2 & of & o) & of & 2 & 1] & of & 1 & 0 & 0 & 0 \\
\hline Lanthers vermalls & $\mathbf{N}$ & 30 & 1 & 0 & 0 & $\mathbf{0}$ & of & of & 0 & o & 0 & 1] & 0 & $\mathbf{0}$ & 0 & 0 & 0 \\
\hline Macromla geangina / Illmolensls & $\mathbf{N}$ & 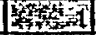 & 1 & $\underline{\mathbf{0}}$ & $\underline{0}$ & 1 & 2 & 0 & 0 & of & 0 & 0 & 1 & $\mathbf{0}$ & 3 & 0 & 0 \\
\hline Neuracondulla vingintersis & $\mathbf{N}$ & 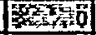 & 0 & $\underline{0}$ & $\underline{0}$ & 0 & 1 & 0 & 0 & of & 0 & 0 & of & $\underline{0}$ & $\underline{0}$ & $\underline{0}$ & 0 \\
\hline Ophlogomphies matmensis & $\mathbf{N}$ & rat & 0 & 2 & $\mathbf{0}$ & o & 0 & 0 & 0 & of & 0 & of & o) & $\mathbf{0}$ & 0 & $\mathbf{0}$ & 0 \\
\hline Progomphus & $\boldsymbol{N}$ & $5 x=0$ & & 5 & 0 & 0 & o & 0 & 0 & o & 0 & 0 & ol & & & & \\
\hline
\end{tabular}

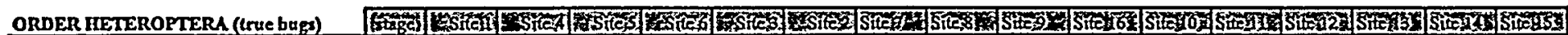

Belostoma lutarivm

Mesovella

Rhagevella obesa

\begin{tabular}{|c|c|c|c|c|}
\hline $\mathbf{N}$ & $\sqrt{E S P 0}$ & 0 & of & 0 \\
\hline $\mathbf{N}$ & $x^{2-9}=6$ & 0 & of & of \\
\hline $\mathbf{N}$ & $18=0$ & 0 & 1) & of \\
\hline
\end{tabular}

\begin{tabular}{l|l|}
\hline 0 & 0 \\
\hline 0 & 0 \\
\hline 0 & 0
\end{tabular}

\begin{tabular}{l|l|}
\hline 0 & 0 \\
\hline 0 & 0 \\
\hline 0 & 1
\end{tabular}

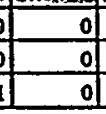


Appendix Table B-2. Species List, Qualitative Sampling of Natural Substrates

Westinghouse Savannah River Company

Sitewide Study

5 Nov. - 8 Dec 1997

\begin{tabular}{|c|c|c|c|c|c|c|c|c|c|c|c|c|c|c|c|c|c|}
\hline & & \multicolumn{16}{|c|}{ SitelH of Organisms } \\
\hline & & \multicolumn{6}{|c|}{ Upper Three Runs Creek System } & \multicolumn{4}{|c|}{ Four Mile Branch System } & \multicolumn{4}{|c|}{ Pen Branch System } & \multicolumn{2}{|c|}{ Steel Cr. System } \\
\hline ORDER EPHEMEROPTERA (maynlies) & Fos & \begin{tabular}{|l|} 
Tims \\
Site 1 \\
\end{tabular} & $\begin{array}{c}\text { Mill } \\
\text { Site } 4 \\
\end{array}$ & \begin{tabular}{l|} 
MoQ \\
Site 5 \\
\end{tabular} & $\begin{array}{l}\text { Crouch } \\
\text { Site } 6\end{array}$ & \begin{tabular}{c|} 
U3R \\
Site 3 \\
\end{tabular} & \begin{tabular}{|c|} 
U3R \\
Site 2 \\
\end{tabular} & $\begin{array}{l}\text { FMB } \\
\text { Site 7 } \\
\end{array}$ & $\begin{array}{l}\text { FMB } \\
\text { Site } 8 \\
\end{array}$ & $\begin{array}{l}\text { FMB } \\
\text { Sites } \\
\end{array}$ & \begin{tabular}{|c|} 
FMB \\
Site 16 \\
\end{tabular} & $\begin{array}{c}\text { Pen } \\
\text { Site 10 } \\
\end{array}$ & $\begin{array}{c}\text { Pea } \\
\text { Site } 11 \\
\end{array}$ & \begin{tabular}{|l} 
Ind. Gr. \\
Sitc 12 \\
\end{tabular} & $\begin{array}{c}\text { Pen } \\
\text { Site 13 } \\
\end{array}$ & $\begin{array}{c}\text { Steel } \\
\text { Site } 14 \\
\end{array}$ & \begin{tabular}{|l|} 
Meyers \\
Sitei15 \\
\end{tabular} \\
\hline Boetis dublum & $\mathrm{N}$ & Fis & 0 & 0 & 0 & 1 & 0 & 0 & 0 & 요 & of & of & 0 & 0 & 0 & 0 & 0 \\
\hline Boetts frondalis & $\mathbf{N}$ & Expro & of & 0 & of & 1 & 0 & 0 & 0 & 25 & of & a & 요 & 요 & 1 & 0 & 5 \\
\hline Boetis intercodaris & $\mathrm{N}$ & 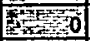 & of & 3 & of & of & 0 & 0 & 요 & 1 & of & of & 1 & 요 & 1 & 0 & 1 \\
\hline Boetts proplingutss & $\mathbf{N}$ & Ylo & of & 0 & 0 & 0 & 7 & 0 & 业 & 0 & of & 0 & of & 0 & 0 & 0 & 0 \\
\hline Colltboctls & $\mathbf{N}$ & 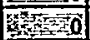 & 0 & 0 & of & 0 & 0 & 0 & 0 & 0 & 1 & of & 0 & 1 & 0 & 0 & 0 \\
\hline Coents diminuta & $\mathbf{N}$ & $\leq 1$ & of & 0 & 0 & - & 0 & 0 & of & 0 & of & 0 & of & 0 & 의 & 0 & $\underline{0}$ \\
\hline Ephemerella (inmoture / damaged) & $\mathbf{N}$ & Rin & of & 0 & of & of & 0 & 0 & of & 0 & of & 0 & 2 & 0 & - & 0 & 1 \\
\hline Enplophello (inmonure / dantoged) & $N$ & $x^{3}=0$ & of & 0 & 요 & of & 0 & 0 & o) & $\underline{0}$ & 의 & of & 요 & 0 & o. & 0 & 1 \\
\hline Eurglophella dorts & $\mathbf{N}$ & 500 & of & 0 & 0 & 0 & 0 & 0 & 0 & $\underline{0}$ & 1 & 0 & 0 & 0 & 0 & 0 & 0 \\
\hline Hecorenta limbata & $\mathbf{N}$ & 40 & 3 & 0 & 0 & 3 & 3 & 0 & 0 & $\underline{0}$ & of & $\therefore 0$ & 0 & 0 & 0 & 0 & 0 \\
\hline Leprophilebla & $N$ & Twis & 0 & 0 & 0 & 0 & 0 & 0 & 0 & $\underline{0}$ & of & 14 & 0 & 0 & 0 & 0 & 0 \\
\hline Neocphemena youngl & $\mathbf{N}$ & 10 & of & 0 & 0 & 1 & 3 & 0 & 0 & 0 & of & of & of & 0 & 1 & 0 & 0 \\
\hline Paraleplophlesla & $\mathbf{N}$ & KED & 4 & 0 & 0 & 0 & 9 & 0 & 0 & 1 & 의 & 0 & 1 & 2 & 0 & 0 & 0 \\
\hline Stenocran treerplanceatums & $\mathbf{N}$ & Fing & 0 & 0 & a & 0 & $\underline{0}$ & 0 & 0 & 0 & 의 & 1 & 0 & 0 & 0 & 0 & 1 \\
\hline Stenonenua nodestendsmithoe & $\mathbf{N}$ & 6 & 5 & 9 & 0 & 1 & 10 & 0 & 0 & 4 & 1 & 1 & 4 & 2 & 0 & 1 & 9 \\
\hline
\end{tabular}

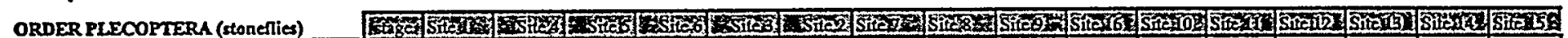

\begin{tabular}{|c|c|c|c|c|c|c|c|c|c|c|c|c|c|c|c|c|c|}
\hline ecromeario abromits & N & 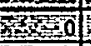 & 5rist & 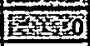 & $8=0$ & Sats & 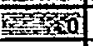 & of & of & of & 0 & of & of & 0 & of & of & 0 \\
\hline Acroneurla lycorios & $\mathbf{N}$ & 16 & 0 & 0 & of & 2 & of & of & 0 & of & 0 & of & of & 0 & of & a & $\underline{0}$ \\
\hline Raronearia mela & $\mathbf{N}$ & 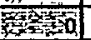 & 1 & 1 & of & of & of & 0 & of & of & of & of & of & 0 & of & 0 & 0 \\
\hline Alloceporda & $N$ & SWT & 0 & 5 & 0 & of & of & of & of & .0 & 요 & 13 & 3 & 0 & of & of & 3 \\
\hline Crioperiaclio & $\mathbf{N}$ & 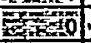 & 4 & 1 & of & 0 & 4 & of & of & 0 & of & of & of & 0 & of & 2 & 1 \\
\hline Isogerla dicola & $\mathbf{N}$ & Hon & 0 & 0 & of & 유 & 1 & of & 0 & of & of & of & of & of & of & of & 0 \\
\hline Lopperla sp & $\mathbf{N}$ & Exis & 0 & $\underline{0}$ & 0 & 2 & of & 0 & of & 0 & of & of & of & 0 & of & of & 0 \\
\hline Lavena & $\mathrm{N}$ & 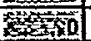 & 0 & 0 & o) & 0 & of & of & of & of. & of & 1 & 0 & 0 & 0 & of & 0 \\
\hline Panegnetina fumasa & $\mathbf{N}$ & ston & 0 & 0 & 0 & 2 & 1 & of & 0 & of & a) & of & o. & of. & 0 & 0 & 0 \\
\hline Perlesta plactia & $\mathbf{N}$ & $5 \times x^{x}$ & 0 & 0 & of & 4 & 2 & of & of & of & of & of & of & of & of & of & 은 \\
\hline Perenciargs & $\mathbf{N}$ & 5 & 0 & $\underline{0}$ & 0 & 1 & 6 & 0 & of & of & of & 0 & of & 0 & of & of & 1 \\
\hline Teenlopteryx meteque & $\mathbf{N}$ & 900 & 1 & $\overline{5}$ & of & 2 & 0 & of & 0 & 15 & i) & 0] & 3 & of & of & of & 6 \\
\hline
\end{tabular}




\section{Appendix Table B-2. Species List, Qualitative Sampling of Natural Substrates}

Westinghouse Savanuah River Company

Sitewide Study

5 Nov. -8 Dec 1997

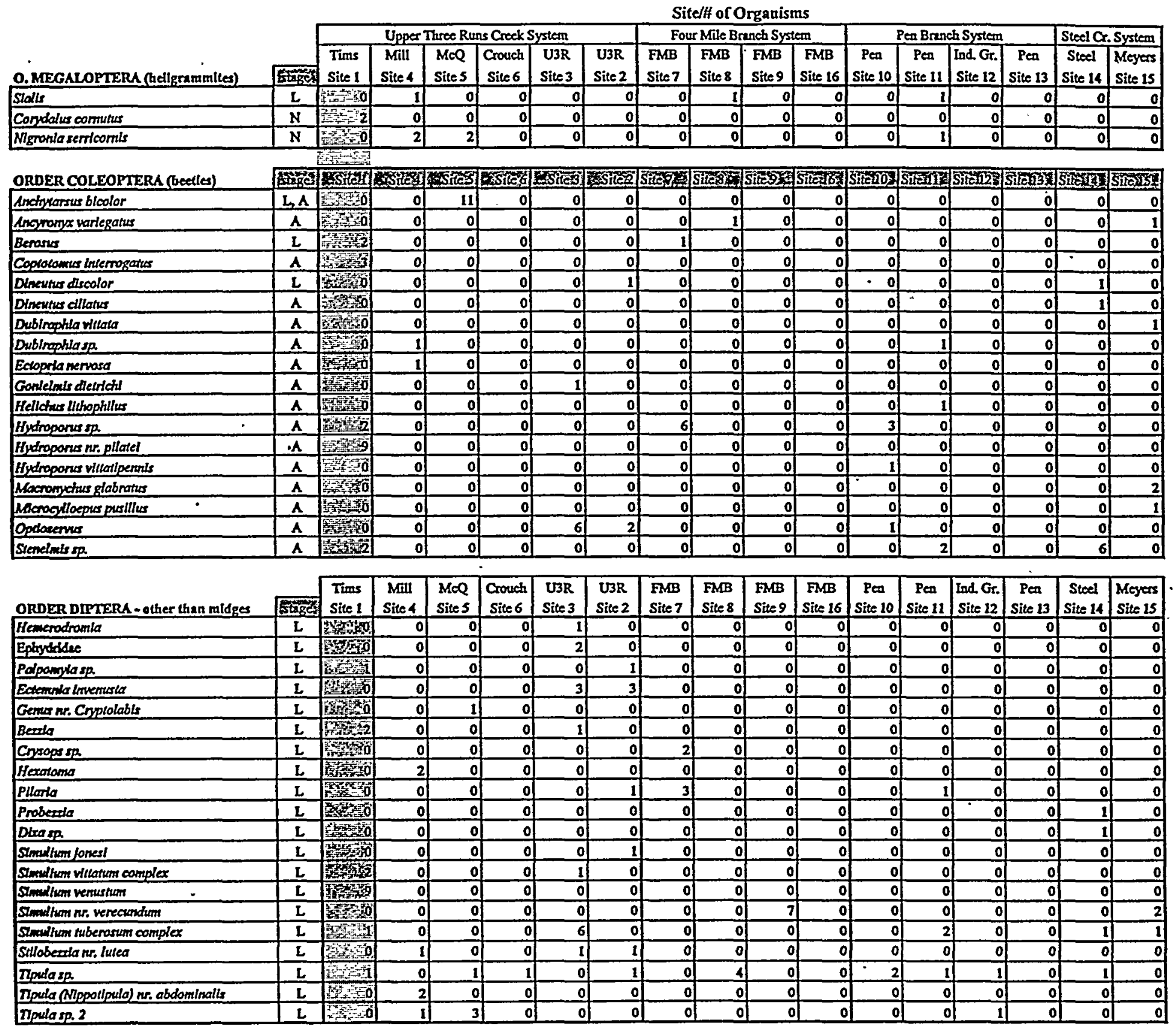




\section{Appendir Table B-2. Species List, Qualitative Sampling of Natural Substrates}

Westinghouse Savanuah River Company

Sitewide Study

5 Nov. - 8 Dec 1997

SitefH of Organisms

\begin{tabular}{|c|c|c|c|c|c|c|c|c|c|c|c|c|c|c|c|c|c|}
\hline \multirow[b]{3}{*}{ ORDER DIPTERA - (Tanypodinae) } & & \multicolumn{16}{|c|}{ Site/H of Organisms } \\
\hline & \multirow[b]{2}{*}{ 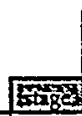 } & \multicolumn{6}{|c|}{ Upper Three Rums Creek System } & \multicolumn{4}{|c|}{ Four Mile Branch System } & \multicolumn{4}{|c|}{ Pen Branch System } & \multicolumn{2}{|c|}{ Steel Cr. System } \\
\hline & & $\begin{array}{r}\text { Tims } \\
\text { Site } 1 \\
\end{array}$ & $\begin{array}{c}\text { Mill } \\
\text { Site } 4 \\
\end{array}$ & $\begin{array}{l}\text { McQ } \\
\text { Sites }\end{array}$ & $\begin{array}{c}\text { Crouch } \\
\text { Site } 6\end{array}$ & $\begin{array}{c}\text { U3R } \\
\text { Site 3 }\end{array}$ & $\begin{array}{c}\text { U3R } \\
\text { Sile 2 }\end{array}$ & \begin{tabular}{|l|} 
FMB \\
Site \\
\end{tabular} & $\begin{array}{l}\text { FMB } \\
\text { Site } 8\end{array}$ & \begin{tabular}{l|} 
FMB \\
Site 9 \\
\end{tabular} & $\begin{array}{c}\text { FMB } \\
\text { Site } 16\end{array}$ & $\begin{array}{c}\text { Pen } \\
\text { Site } 10\end{array}$ & $\begin{array}{c}\text { Pen } \\
\text { Site 11 } \\
\end{array}$ & $\begin{array}{l}\text { Ind. Gr. } \\
\text { Site } 12\end{array}$ & \begin{tabular}{|c|} 
Pen \\
Site 13
\end{tabular} & \begin{tabular}{|c|} 
Stcel \\
Site 14
\end{tabular} & \begin{tabular}{|l|} 
Meyers \\
Sitc 15
\end{tabular} \\
\hline Ablebesmyia malloct & L & $8 x=0$ & 1 & 0 & 0 & of & 1 & 0 & 0 & 0 & 2 & 0 & 0 & 0 & 0 & 0 & 0 \\
\hline Ablabesmira jartla gp. & $\mathbf{L}$ & 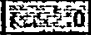 & 0 & 0 & 0 & 0 & 0 & $x^{2} x$ & 0 & 0 & of & 0 & 0 & 0 & 0 & 0 & -1 \\
\hline Ablabesmyla nu. peleensis & $\mathbf{L}$ & 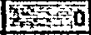 & 0 & 0 & 0 & 0 & 0 & 1 & of & 0 & of & 0 & of & 0 & 0 & 0 & 0 \\
\hline Clinotompers pinguls & L & 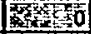 & 0 & 0 & 0 & 3 & 0 & 1 & of & 0 & 0 & 3 & 0 & 0 & 2 & 0 & 0 \\
\hline Conchicpelopla & 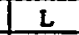 & 30 & 은 & 0 & 0 & 1 & 8 & 0 & 0 & 0 & 아 & 0 & 0 & 0 & 0 & 0 & 0 \\
\hline Labrandinta pllosella & $L$ & 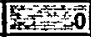 & 0 & 0 & 0 & o. & 1 & 0 & of & 0 & o) & 0 & 0 & 0 & o) & 0 & 0 \\
\hline Nolarsia & $\mathbf{L}$ & Esisto & o & 0 & 0 & of & 0 & 0 & 0 & 0 & - & 1 & of & 0 & 0 & 0 & 0 \\
\hline Panamertixa & L & 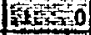 & 1 & 2 & 0 & of & 0 & 0 & 0 & 1 & of & 0 & 0 & 0 & 0 & 0 & \\
\hline Zancellimia & $\mathbf{L}$ & 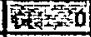 & 0 & 0 & 0 & of & 1 & 0 & 0 & 0 & o] & - 2 & I] & 0 & of & 0 & \\
\hline Prododius & L & 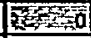 & 0 & 0 & 0 & of & 0 & 1 & 0 & 0 & 0 & 1) & 0 & 0 & 1 & 0 & 0 \\
\hline Tarppus punetipernis & $L$ & Fris: & 0 & 0 & 0 & of & 0 & 1 & 0 & 0 & of & 0 & 0 & 0 & 0 & 0 & \\
\hline
\end{tabular}

\begin{tabular}{|c|c|c|c|c|c|c|c|c|c|c|c|c|c|c|c|c|c|}
\hline or & 586 & Esica & Essing & WFSt & Histe & She & 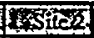 & Siftar & SIER & SHowas & 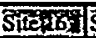 & Sifrina & Sfres: & Sries? & Sirvist & ST: & Sifusts \\
\hline Brillla favifrors & $\mathbf{L}$ & 89 & of & 0 & 0 & of & 0 & of & of & of & of & of & of & of & 0 & 1 & \\
\hline Conmoneura & L & 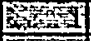 & 1 & 0 & 0 & of & 0 & of & of & of & of & of & 2 & 3 & 0 & 1 & $\underline{0}$ \\
\hline (Dlamestinae)-Potthortla longimang & $\mathbf{L}$ & 6150 & of & 1 & of & of & of & 요 & 의 & of & of & of & of & of & 0 & of & $\underline{0}$ \\
\hline Crleotopess eremulis ge. & $\mathbf{L}$ & sistis & of & of & of & of & 의 & of & of & of & 2 & of & of & of & 0 & 의 & \\
\hline Cricolopus bleinertus & $\mathbf{L}$ & S & 의 & 0 & 1 & of & 요 & 의 & of & 1 & of & of & of & of & 1 & 0 & \\
\hline Eublefferiella doripermis gp. & $\mathbf{L}$ & 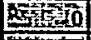 & 이 & 0 & of & of & 0 & of & of & of & of & of & of & of & 0 & 1 & \\
\hline Genes ntr. Narnodadier B & $L$ & 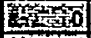 & of & 0 & of 10 & of & 0 & 0 & 1 & of & of & of & of & of & 0 & of & \\
\hline 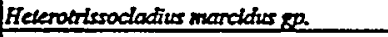 & $L$ & 0 & 0 & 0 & of & of & 0 & of & of & of & of & 1 & of & of & 0 & of & \\
\hline Nanodadies & L & 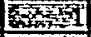 & of & 0 & of & 1 & 의 & of & of & of & of & of & 1 & of & 0 & 0 & \\
\hline Onthodadius sp & $L$ & 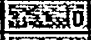 & 0 & 요 & of & of & of & of & of & 0 & of & of & of & of & 2 & 0 & \\
\hline Orthodadies obumbratus & $L$ & S250 & 0 & 0 & of & of & 0 & of & of & of & 20 & of & of & of & 8 & 0 & \\
\hline Panatiefferiella & $\mathbf{L}$ & 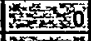 & 0 & 0 & of & of & 1 & of & of & of & 2 & of & 1 & if & of & 아 & \\
\hline Pancanetrioenentus lundbecth & $\mathbf{L}$ & Ex & 1 & 2 & of & 1) & 1 & of & of & of & 의 & 3) & 2 & (1) & 1 & 의 & \\
\hline Pseudorthocloditus sp. & $\mathbf{L}$ & L & 0 & 0 & of & of & 0 & 2 & of & of & of & of & 0 & of & of & 0 & \\
\hline Rheocticotophs robacts & $\mathbf{L}$ & 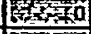 & 1 & 1 & of & of & 10 & of & of & of & 1 & of & of & of & of & 3 & \\
\hline Iftenemertrilella xena gp. & $\mathbf{L}$ & 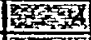 & 0 & 0 & 의 & of & 1 & 0 & of & 2 & 2 & of & 0 & 2 & of & 0 & \\
\hline 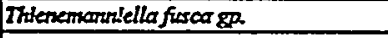 & L & $5 \mathrm{x}^{2} 6$ & 0 & 0 & of & of & 1 & 0 & of & of & 요 & 0) & 1 & 의 & t) & 0 & \\
\hline Inetenta pascencea op. & $\mathbf{L}$ & F & 0 & 0 & of & of & of & 의 & of & of & of & 요 & 요 & of & 1 & 1 & \\
\hline Thelenda discoloripes gp. & $\mathbf{L}$ & 60 & o & 0 & of & 1 & 6 & 의 & of & of & of & of & 0 & of & -0) & 0 & $\underline{0}$ \\
\hline Utratella multivinga & $\mathbf{L}$ & 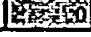 & 0 & 0 & o) & o] & 1 & of & of & of & 0 & 11 & 0 & of & 0 & 0 & \\
\hline
\end{tabular}

\begin{tabular}{|c|c|c|c|c|c|c|c|c|c|c|c|c|c|c|c|c|c|}
\hline ORDER DIPTER & sare & Siton & Sted & Asitus & Sing & Sisifa & Asifen & Sic5) & Sifes & $5 x+3$ & sitona & Siteron & stintin: & Stectits & Siction & Frital & 5 \\
\hline Copplocthromontes fulves gen & $\mathbf{L}$ & 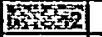 & 1 & of & of & 0 & 1 & of & of & of & of & of & of & of & 0 & of & o \\
\hline Chlonomitus & $\mathbf{L}$ & 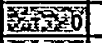 & 0 & of & of & 0 & 이 & 7 & 0 & of & of & 0 & of & of & of & of & 0 \\
\hline Dicrolendipes nr. neamodestus & $L$ & Exis & 0 & of & - & 0 & of & 0 & of & 2 & 1 & 0 & of & 0 & 0 & 0 & 0 \\
\hline Elingeldia & L & 67 & 0 & 요 & of & 0 & of & 0 & of & of & of & 0 & 0 & 0 & 0 & of & 0 \\
\hline sacrosendipes nus. pedellus & $\mathbf{L}$ & $2 x=0$ & 1 & 요 & 0 & 0 & 2 & 0 & 0 & of & o. & 61 & of & 2 & 0 & 의 & 0 \\
\hline hoerotendipes nar. opdadensis & $L$ & 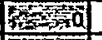 & o & 0 & a & 0 & 1 & 0 & 0 & 0 & of & 0 & of & 이 & 0 & of & 0 \\
\hline Nllotharma & $\mathrm{L}$ & 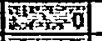 & 0 & 익 & 요 & 0 & 1 & 0 & of & of & of & 의 & 0 & o) & 0 & 0 & 0 \\
\hline Pagartiella & $\mathbf{L}$ & 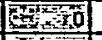 & 요 & 0 & of & 0 & 요 & 0 & 0 & of & of & 0 & 1 & of & 0 & o & ㅇ․ \\
\hline Papactironomis monochivomiss & L & 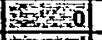 & 0 & 0 & 의 & 의 & 0 & 1 & 0 & of & of & 0 & 요 & of & 0 & of & 의 \\
\hline Paralouterbormiella rigrohalieralls & $\underline{L}$ & ratsons & 0 & 0 & 의 & 0 & 1 & 0 & 0 & of & 의 & of & of & of & 의 & 의 & 0 \\
\hline Pharenopsectra flavipes & $\mathbf{L}$ & 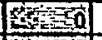 & 0 & 0 & 0 & 0 & 0 & $\underline{0}$ & 0 & 1 & 0 & 1 & 0 & of & 의 & 의 & 0 \\
\hline Trbelos jucenctum & L & Fent & 0 & 0 & 0 & 0 & of & $\underline{0}$ & 0 & of & 으 & 0 & 0 & 2 & 9 & 의 & 의 \\
\hline Pseudoctilionomiss & $\mathbf{L}$ & xita & 0 & 0 & 0 & 0 & 의 & 1 & o & 의 & of & 으 & of & 의 & 의 & of & 은 \\
\hline Polypedilunt awioeps & $\mathbf{L}$ & Fin & 11 & 8 & 의 & 은 & of & $\underline{0}$ & 0 & 3 & 은 & 4 & 1 & of & of & 5 & \\
\hline Polypedilum artoeps & $\mathbf{L}$ & 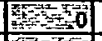 & $\underline{0}$ & 0 & 0 & 0 & 28 & $\overline{0}$ & 0 & 익 & 0 & 0 & 의 & 0 & of & 0 & \\
\hline Polypedilum Illinoense & L & 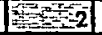 & 0 & & 0 & & & & & & & & & & & & \\
\hline
\end{tabular}


Appendix Table B-3. Macroinvertebrate Data, by Replicate

Client: Westinghouse Savannah River Company

Stream: Tims Branch (Site 1)

County: Barnwell, SC

Collection Date: 5 Nov - 8 Dec 1997

Site / \# of Organisms

ORDER EPHEMEROPTERA (maynie Sta Rep

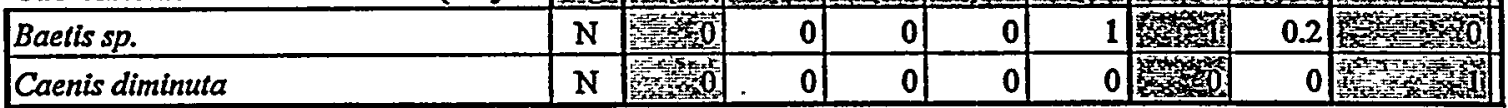

\begin{tabular}{|c|c|c|c|c|c|c|c|c|c|}
\hline ORDER TRICHOPTERA (caddisflies) & Statioge & Rep & 57B & Repic: & ED & Rep & 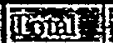 & Mean: & Gealtion \\
\hline Cheumatopsyche & L & 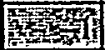 & 3 & 0 & 0 & 0 & My & 0.8 & Fing \\
\hline Hydropsyche betteni & $\bar{L}$ & 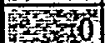 & $\overline{0}$ & 0 & 2 & $\overline{0}$ & 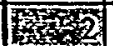 & 0.4 & $\lim _{1}$ \\
\hline
\end{tabular}

\begin{tabular}{|c|c|c|c|c|c|c|c|c|c|}
\hline ORDER ODONATA (dragonflies) & 5 & RED & pi & Rep & Repin & Bepis & Toral & 2 & Oualifare \\
\hline Calopteryx dimidiata & $\mathbf{N}$ & 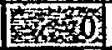 & 0 & 0 & 0 & 0 & 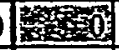 & 0 & st \\
\hline Enallagma sp. & $\mathbf{N}$ & 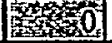 & 0 & $\mathbf{0}$ & $\mathbf{0}$ & $\mathbf{0}$ & 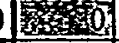 & $\mathbf{0}$ & 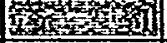 \\
\hline Gomphus lividus & $\mathbf{N}$ & 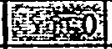 & 0 & 0 & 0 & $\underline{0}$ & 20 & 0 & 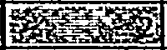 \\
\hline Libellula & $\mathrm{N}$ & 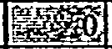 & 0 & $\mathbf{0}$ & 0 & $\underline{0}$ & 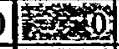 & $\underline{0}$ & Gex \\
\hline Macromia georgina / illinoiensis & $\mathbf{N}$ & 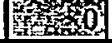 & 0 & $\underline{0}$ & $\mathbf{0}$ & 0 & 0 & $\mathbf{0}$ & 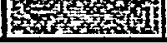 \\
\hline
\end{tabular}

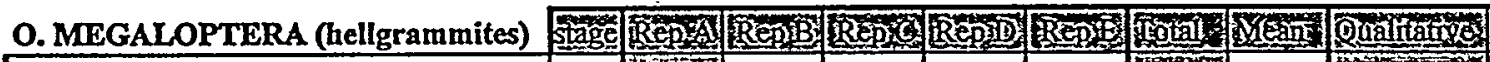

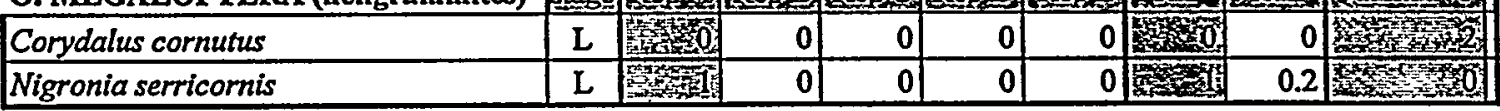

\begin{tabular}{|c|c|c|c|c|c|c|c|c|c|}
\hline ORDER COLEOPTERA (beetles) & Sisce & 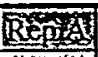 & EEPB & Repric & Repin & Pepe & 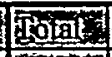 & Tean & Quiftaciog \\
\hline Berosus & $\mathbf{L}$ & 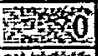 & 0 & 0 & 이 & 0 & 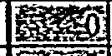 & $\underline{0}$ & 15. \\
\hline Coptotomus interrogatus & $A$ & 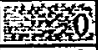 & 0 & $\underline{0}$ & 0 & 0 & 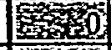 & $\underline{0}$ & 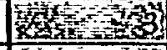 \\
\hline Hydroporus sp. & A & $\frac{1}{3}$ & 0 & 0 & 0 & 0 & 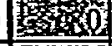 & $\underline{0}$ & 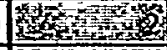 \\
\hline Hydroporus nr. pilatei & A & 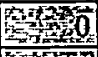 & 0 & 0 & 0 & $\underline{0}$ & 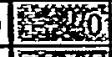 & $\underline{\mathbf{0}}$ & 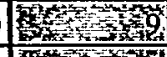 \\
\hline Stenelmis sp. & L & Binto & 0 & 0 & 0 & 0 & 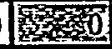 & 0 & 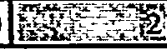 \\
\hline
\end{tabular}

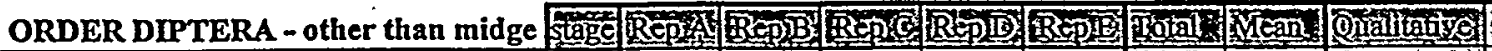

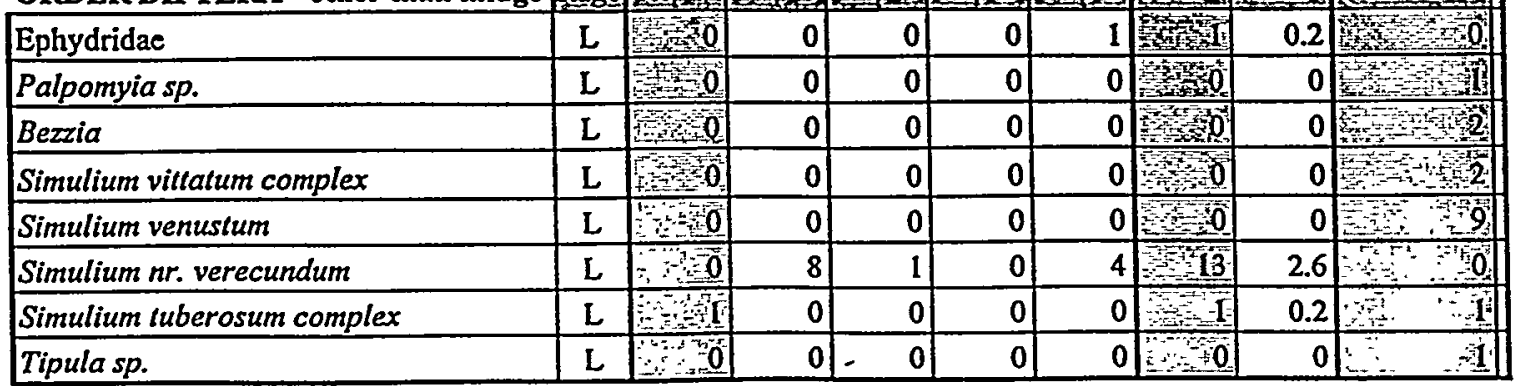




\section{Appendix Table B-2. Species List, Qualitative Sampling of Natural Substrates \\ Westinghouse Sayannah River Company \\ Sitewide Study \\ 5 Nov. - 8 Dec 1997}

\begin{tabular}{|c|c|c|c|c|c|c|c|c|c|c|c|c|c|c|c|c|c|}
\hline \multirow[b]{3}{*}{ ORDER DIPTERA - (Tanytarzini) } & \multirow[b]{3}{*}{ 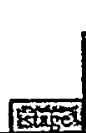 } & \multicolumn{16}{|c|}{ Site/H of Organisms } \\
\hline & & \multicolumn{6}{|c|}{ Upper Three Rums Creek System } & \multicolumn{4}{|c|}{ Four Mite Branch System } & \multicolumn{4}{|c|}{ Pen Branch System } & \multicolumn{2}{|c|}{ Stecl Cr. System } \\
\hline & & \begin{tabular}{c|} 
Tims \\
Site 1 \\
\end{tabular} & $\begin{array}{c}\text { Mall } \\
\text { Site } 4\end{array}$ & $\begin{array}{l}\text { MOQ } \\
\text { Site } 5\end{array}$ & $\begin{array}{l}\text { Crouch } \\
\text { Site } 6\end{array}$ & $\begin{array}{c}\text { U3R } \\
\text { Site } 3\end{array}$ & $\begin{array}{c}\text { U3R } \\
\text { Site 2 } \\
\end{array}$ & \begin{tabular}{|l|} 
FMB \\
Site 7 \\
\end{tabular} & $\begin{array}{l}\text { FMB } \\
\text { Site } 8 \\
\end{array}$ & $\begin{array}{l}\text { FMB } \\
\text { Site } 9 \\
\end{array}$ & $\begin{array}{c}\text { FMB } \\
\text { Site 16 } \\
\end{array}$ & $\begin{array}{c}\text { Pen } \\
\text { Sitc 10 } \\
\end{array}$ & $\begin{array}{c}\text { Pear } \\
\text { Site } 11\end{array}$ & $\begin{array}{l}\text { Ind } G r . \\
\text { Sitc } 12\end{array}$ & $\begin{array}{c}\text { Pen } \\
\text { Site } 13\end{array}$ & \begin{tabular}{|c|} 
Stcel \\
Site 14
\end{tabular} & $\begin{array}{l}\text { Meyers } \\
\text { Sile } 15\end{array}$ \\
\hline Cladocanyearsess sp & L & $E=0$ & 0 & 0 & 0 & 0 & 0 & 0 & 0 & 0 & 0 & 0 & 0 & 0 & 1 & 0 & \\
\hline Parchanylarsis & $\mathbf{L}$ & Fen & 0 & $\underline{0}$ & 의 & of & 0 & of & 1 & $\underline{0}$ & $\underline{\mathbf{0}}$ & 0 & $\underline{0}$ & of & $\underline{0}$ & $\mathbf{0}$ & \\
\hline 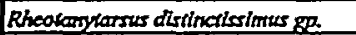 & L,P & $37=29$ & 1 & 2 & of & 9. & 5. & of & $\underline{0}$ & $\underline{0}$ & 3 & 1 & 4 & 1 & 10 & 4 & \\
\hline Rheolongratross exlgurus gp. & L,P & 50 & $\underline{0}$ & $\underline{0}$ & 의 & of & 1 & of & $\underline{0}$ & $\underline{0}$ & $\underline{0}$ & $\underline{0}$ & $\underline{0}$ & of & $\underline{0}$ & $\underline{0}$ & \\
\hline Tanntanus & L,P & aring & 2 & 1 & 0 & of & 5 & 3 & $\mathbf{0}$ & $\mathbf{0}$ & & & o & 2 & & & \\
\hline
\end{tabular}

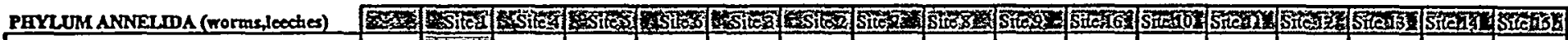
Tubificider (w/o cen setac)

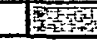

\begin{tabular}{|c|c|c|c|c|c|c|c|c|c|c|c|c|c|c|c|c|c|}
\hline ISTACEAC & Exte & Estran & SFitic & Sint & Find & SStict & Silion & Site 0 & 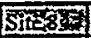 & Sircos & 5 & Siflat & Fitein & 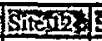 & Stens & Site? & Sifets: \\
\hline Cemberine & $\mathrm{J}, \mathrm{A}$ & 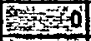 & 4 & 0 & 3 & 4 & 3 & 0 & 우 & 0 & 1 & 0 & 7 & of & 2 & 14 & 4 \\
\hline Hyotlelo artecas & $\mathrm{J}$ & 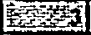 & of & $\mathbf{0}$ & 0 & 0 & 0 & 0 & 의 & 이 & 26 & 이 & 0 & 38 & 2 & o] & 1 \\
\hline Cramgony abligurestichmondensts & 3 & E & of & o & 의 & 0 & 0 & $\mathbf{0}$ & 0 & 1 & $\mathbf{0}$ & of & 0 & o] & 0 & 0 & $\mathbf{0}$ \\
\hline Poloemanetes poludares & I & 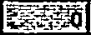 & 10 & 1 & of & 0 & 4 & 0 & 0 & o] & 0 & 3 & 10 & of & 28 & 0 & 16 \\
\hline
\end{tabular}

ORDER LEPIDOPTERA (moths)

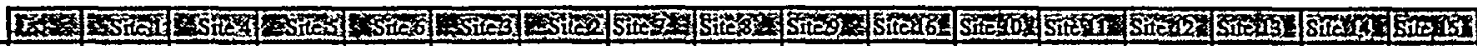

Parapogrex obscuradis L

PHYLUM MOLLUSCA (dems, snails)

Renicola linosa

Compeloma decisum ..

Corblata finminea

Hellsorra anceps

Sphoentiva:

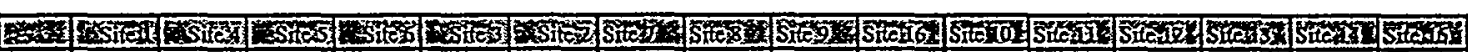

Phosella heterastropha

\begin{tabular}{|c|c|c|c|c|c|c|c|c|c|c|c|c|c|c|c|c|}
\hline sasil & $5=0$ & 0 & 0 & 0 & ol & 4 & of & 0 & of & 3 & 0 & 의 & 0 & 1 & 0 & 의 \\
\hline porail & $x^{2}=0$ & 9 & 2 & of & 0 & 3 & 0 & 1 & 의 & 0 & 10 & 0 & 0 & 0 & 0 & 0 \\
\hline clam & 50 & 1 & 0 & 0 & 0 & 0 & of & 0 & 2 & 10 & 0 & 2 & 1 & 12 & 1 & 0 \\
\hline cansil & $4 x=0$ & 0 & 0 & of & 0 & 0 & 0 & 0 & of & 0 & o & 의 & 6 & 2 & 0 & 응 \\
\hline claser & 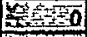 & 요 & o) & of & 0 & 의 & 1 & 1 & of & 의 & 3) & 3 & 1 & 6 & 0 & 2 \\
\hline snail & $R_{*}=\geq 0$ & 0 & 0 & 0) & 0 & 0 & 0 & 0 & 25 & 3 & of & 0 & 0 & 0 & 3 & 1 \\
\hline
\end{tabular}




\section{Appendix Table B-3. Macroinvertebrate Data, by Replicate}

\section{Client: Westinghouse Savannah River Company}

Stream: Tims Branch (Site 1)

County: Barnwell, SC

Collection Date: 5 Nov - 8 Dec 1997

Site / \# of Organisms

ORDER DIPTERA - (Tanypodinae)

Conchapelopia

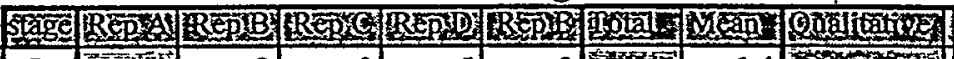

\begin{tabular}{|c|c|c|}
\hline L & .7 & 2 \\
\hline
\end{tabular}

\begin{tabular}{|c|c|c|c|c|c|c|c|c|c|}
\hline ORDER DIPTERA - (Orthocladiinae) & stage & Eepat & EP: & $2+9$ & Rep & 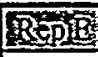 & Iotails & Man & Oinalitas \\
\hline Corynoneura & $\mathbf{L}$ & $\sqrt{1+9}$ & 0 & 0 & 2 & $\underline{0}$ & 3. & 0.4 & OEx \\
\hline Cricotopus bicinctus & $L$ & 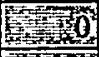 & 1 & 0 & 1 & $\underline{0}$ & 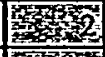 & 0.4 & 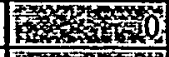 \\
\hline Nanocladius & $\mathrm{L}$ & 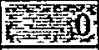 & 0 & 0 & 0 & 0 & 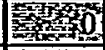 & 0 & 6 \\
\hline Parametriocnemus lindbecki & $\mathbf{L}, \mathbf{P}$ & Pats & 0 & 0 & 0 & $\mathbf{0}$ & (1) & $\mathbf{0}$ & 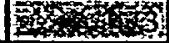 \\
\hline Rheocricotopus robacki & $\mathbf{L}$ & 8 & 0 & 1 & 0 & $\underline{0}$ & 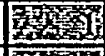 & 0.2 & 器 \\
\hline Thienemanniella xena gp. & $\mathbf{L}$ & 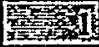 & 1 & 0 & 1 & $\mathbf{0}$ & 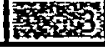 & 0.6 & 13 \\
\hline
\end{tabular}

\begin{tabular}{|c|c|c|c|c|c|c|c|c|c|}
\hline ORDER DIPTERA - (Chironomini) & Stage & Eep & Rep & Bepig & Repis: & Rep & gtalu & ean & Chatiatio \\
\hline Cryptochironomus fulvus gp. & $\mathbf{L}$ & 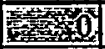 & 0 & 0 & 요 & 0 & 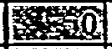 & 0 & 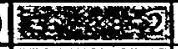 \\
\hline Einfeldia & $\mathbf{L}$ & 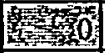 & $\underline{0}$ & 0 & 0 & 0 & 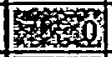 & 0 & 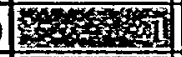 \\
\hline Tribelos jucundum & $\mathbf{L}$ & 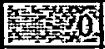 & 0 & 0 & 1 & 0 & 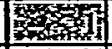 & 0.2 & 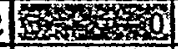 \\
\hline Polypedilum aviceps & $\mathrm{L}$ & 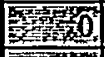 & $\underline{0}$ & 0 & 0 & 0 & 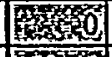 & & 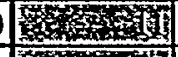 \\
\hline Polypedilum illinoense & L & 15ing & 0 & 0 & 0 & 0 & 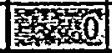 & & 6 \\
\hline
\end{tabular}

ORDER DIPTERA - (Tanytarsini)

Rheotanytarsus distinctissimus gp. Tanytarsus

\begin{tabular}{|c|c|c|c|c|c|c|c|c|}
\hline 5 & Beps & Repis & ep: & Repin & Rp窟 & iftal & Ean & Quaifitive \\
\hline L & mat & 4 & 0 & 1 & I & 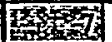 & 1. & 2 \\
\hline $\mathbf{P}$ & 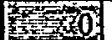 & 0 & 1 & 2 & 0 & 4 & 0. & 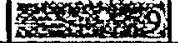 \\
\hline
\end{tabular}

PHYLUM ANNELDA (worms, leeches

Nais communis

Tubificidae (w/o cap. setae)

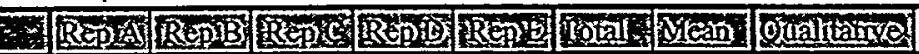

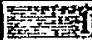

Bing

\begin{tabular}{|c|c|c|c|c|c|c|}
\hline$\overline{0}$ & $0 \mid$ & 0 & 0 & 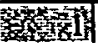 & 0.2 & 2 \\
\hline & 16 & 0 & & 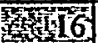 & 3.2 & 2 \\
\hline
\end{tabular}

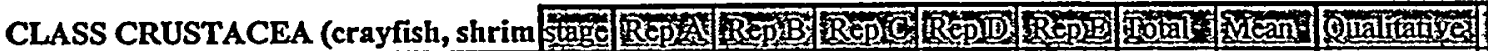
Hyallela azteca $\mathrm{J} \mid$\begin{tabular}{rr|}
3 & 0 \\
\hline
\end{tabular} 0 istio 


\section{Appendix Table B-3. Macroinvertebrate Data, by Replicate}

Client: Westinghouse Savannah River Company

Stream: Upper Three Runs Creek (Site 2)

County: Aiken, SC

Collection Date: 5 Nov - 8 Dec 1997

Site / \# of Organisms

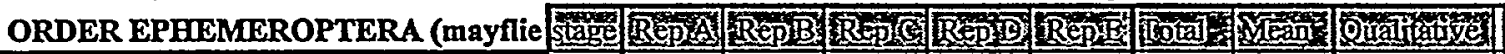

\begin{tabular}{|c|c|c|c|c|c|c|c|c|c|}
\hline Acentrella ampla & $\mathrm{N}$. & 171 & 0 & 0 & 0 & 0 & 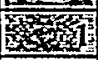 & 0.2 & 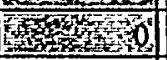 \\
\hline Baetis intercalaris & $\mathbf{N}$ & 4 & 0 & 1 & 0 & 0 & 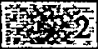 & 0.4 & \\
\hline Baetis propinquus & $\mathbf{N}$ & 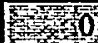 & $\mathbf{0}$ & $\mathbf{0}$ & $\mathbf{0}$ & $\mathbf{0}$ & Tx & $\mathbf{0}$ & \\
\hline Eurylophella (immature / damaged) & $\mathbf{N}$ & 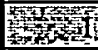 & 0 & 0 & 0 & 0 & 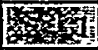 & 0.2 & 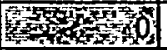 \\
\hline Heptagenia & $\mathbf{N}$ & 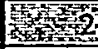 & 1 & $\underline{0}$ & 2 & 0 & 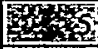 & 1 & Ste \\
\hline Hexagenia limbata & $\mathrm{N}$ & 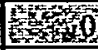 & $\mathbf{0}$ & $\underline{0}$ & 0 & 0 & 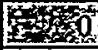 & 0 & 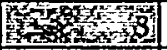 \\
\hline Neoephemera youngi & $\mathbf{N}$ & 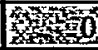 & $\mathbf{0}$ & 0 & 0 . & 0 & 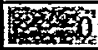 & 0 & sy \\
\hline Paraleptophlebia & $\mathbf{N}$ & 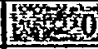 & 0 & 0 & 0 & 0 & 8 & 0 & 5 \\
\hline Stenonema modestum/smithae & $\mathbf{N}$ & 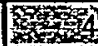 & 7 & 3 & $\mathbf{0}$ & $\mathbf{0}$ & 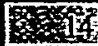 & 2.8 & \\
\hline
\end{tabular}

\begin{tabular}{|c|c|c|c|c|c|c|c|c|c|}
\hline ORDER PLECOPTERA (stoneflies) & State & Exep & Rets & Beng & RED & 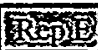 & cota & Mean & Quaditio \\
\hline Acroneuria abnormis & $\mathbf{N}$ & 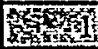 & 2 & 1 & 4 & $\overline{1}$ & 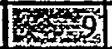 & 1.8 & Fon \\
\hline Acroneuria mela & $\mathbf{N}$ & 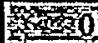 & 0 & 1 & $\mathbf{0}$ & $\mathbf{0}$ & 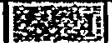 & 0.2 & Wer \\
\hline Allocapnia & $\mathbf{N}$ & 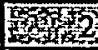 & 0 & 2 & 0 & 0 & 28 & 0.8 & 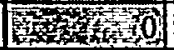 \\
\hline Clioperla clio & $\mathbf{N}$ & Sh⿻ & 0 & 0 & 0 & $\mathbf{0}$ & 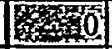 & 0 & Fin \\
\hline Isoperla dicala & $\mathbf{N}$ & 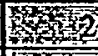 & 1 & 9 & 2 & 0 & 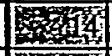 & 2.8 & 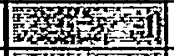 \\
\hline Paragnetina fumosa : & $\mathbf{N}$ & 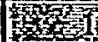 & $\mathbf{0}$ & 1) & 1 & $\mathbf{0}$ & 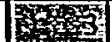 & 0.6 & 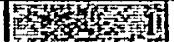 \\
\hline Perlesta placida & $\mathbf{N}$ & 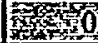 & 1 & 2 & $\mathbf{0}$ & $\mathbf{0}$ & 5 & 0.6 & F \\
\hline Pteronarcys & $\mathbf{N}$ & 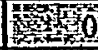 & 0 & 1 & 0 & 2 & So & 0.6 & $547 y^{3}=6$ \\
\hline Taeniopteryx metequi & $\mathbf{N}$ & 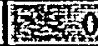 & 0 & 1 & $\mathbf{0}$ & $\mathbf{0}$ & 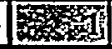 & 0.2 & 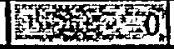 \\
\hline
\end{tabular}


Appendix Table B-3. Macroinvertebrate Data, by Replicate

Client: Westinghouse Savannah River Company

Stream: Upper Three Runs Creek (Site 2)

County: Aiken, SC

Collection Date: 5 Nov - 8 Dec 1997

ORDER COLEOPTERA (beetles)

\begin{tabular}{|c|c|c|c|c|c|c|c|c|c|}
\hline Dineutus discolor & A & 130 & 1 & $\underline{0}$ & 0 & 0 & $\frac{1}{2} \times 4$ & 0.2 & Fint \\
\hline Macronychus glabratus & $\mathrm{L}, \mathrm{A}$ & $x$ & 1 & 0 & 0 & 0 & 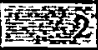 & 0.4 & 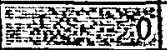 \\
\hline Optioservus & L & 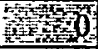 & 0 & 0 & 0 & 0 & 50 & 0 & Whats \\
\hline Stenelmis sp. & L & 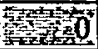 & 0 & 0 & 1 & 0 & 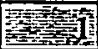 & 0.2 & 1345 \\
\hline
\end{tabular}

ORDER DIPTERA - other than midges Stage Bep

\begin{tabular}{|c|c|c|c|c|c|c|c|c|c|}
\hline Atherix lantha & & Xon & 2 & 0 & 0 & & 7is & 0.4 & 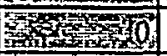 \\
\hline Palpomyia sp. & $\bar{L}$ & matson & 0 & 0 & $\mathbf{0}$ & $\overline{0}$ & 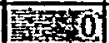 & $\overline{0}$ & 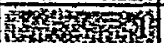 \\
\hline Ectemnia invenusta & L & 20 & 0 & 0 & $\mathbf{0}$ & $\mathbf{0}$ & Fisons & $\begin{array}{lll}0 & & \\
0\end{array}$ & 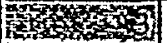 \\
\hline Pilaria & $\mathrm{L}$ & 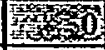 & 0 & 0 & 0 & $\underline{0}$ & 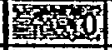 & 0 & 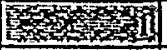 \\
\hline Slmulium jonesi & $\mathrm{L}$ & 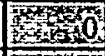 & 0 & 0 & $\underline{0}$ & $\underline{0}$ & 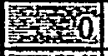 & $\underline{0}$ & int \\
\hline Stilobezzia nr. lutea & $\mathbf{L}$ & 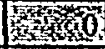 & 0 & 0 & $\underline{0}$ & 0 & 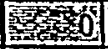 & 0 & \\
\hline Tipula sp. & $\mathbf{L}$ & 0 & 0 & $\mathbf{0}$ & 0 & 0 & 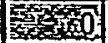 & $\mathbf{0}$ & S \\
\hline
\end{tabular}

\begin{tabular}{|c|c|c|c|c|c|c|c|c|c|}
\hline ORDER DIPTERA - (Tanypodinae) & stage & Sépin & etest & 定epe & REDT: & Peping & Total & Veant & 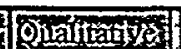 \\
\hline Ablabesmyia mallochi & $\mathbf{L}$ & 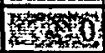 & 0 & 0 & 0 & 0 & 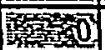 & 0 & | \\
\hline Conchapelopia & $\bar{L}$ & 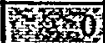 & 0 & $\overline{0}$ & 0 & 0 & 30 & $\overline{0}$ & 10 \\
\hline Labrundinia pilosella & $L$ & 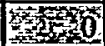 & 0 & 0 & 0 & 0 & 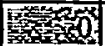 & 0 & $\mid$ \\
\hline Zavrelimyia & $\mathbf{L}$ & ros & 0 & 0 & 0 & 0 & 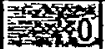 & 0 & 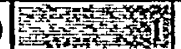 \\
\hline
\end{tabular}

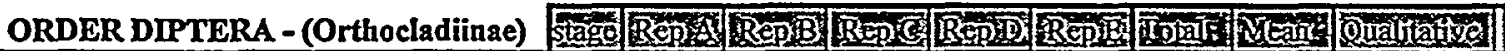

\begin{tabular}{|c|c|c|c|c|c|c|c|c|c|c|}
\hline Brillia flavifrons & L & 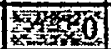 & 0 & 2 & 0 & & & 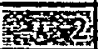 & 0.4 & 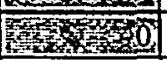 \\
\hline Corynoneura & $\mathrm{L}$ & 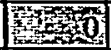 & 0 & 1 & c & & 0 & 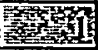 & 0.2 & 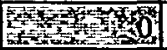 \\
\hline Eukiefferiella claripennis gp. & L & 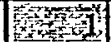 & $\mathbf{0}$ & 0 & c & & 0 & 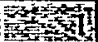 & 0.2 & 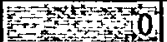 \\
\hline Orthocladius nr. carlatus & $\mathrm{L}$ & 10 & 0 & 6 & 1 & 1 & 0 & 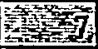 & 1.4 & Py \\
\hline Parakiefferiella & $\mathrm{L}$ & 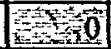 & 0 & 2 & ( & 0 & 0 & $=1$ & 0.4 & ris \\
\hline Parametriocnemus lundbecki & $L, P$ & 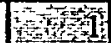 & $\mathbf{0}$ & 6 & 2 & 2 & 0 & T3 & 1.8 & 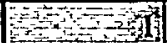 \\
\hline Rheocricotopus robacki & L & 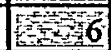 & 10 & 40 & & 7 & 2 & Prits & 13 & ran \\
\hline Synorthocladius semivirens & $\bar{L}$ & $8 x=0$ & 1 & $\overline{0}$ & & 0 & 0 & 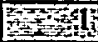 & 0.2 & 50 \\
\hline Thienemanniella xena gp. & $\bar{L}$ & $x_{1}=0$ & 1 & $\overline{0}$ & & of & 0 & PYin & 0.2 & Pats \\
\hline Thienemanniella fusca $\mathrm{gp}$. & L & 在 & 0 & 0 & & 0 & 0 & 80 & 0 & 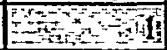 \\
\hline Tvelenia paucunca gp. & L & 50 & 0 & 1 & 1 & 0 & 0 & Fin & 0.2 & -4 \\
\hline Tvetenia discoloripes gp. & L & Btis & 1 & 3 & 3 & 2 & 0 & 6 & 1.2 & 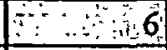 \\
\hline Unniella multivirga & L & $=0$ & 0 & - & & 0 & 0 & 10 & 0 & \\
\hline
\end{tabular}


Appendix Table B-3. Macroinvertebrate Data, by Replicate

Client: Westinghouse Savannah River Company

Stream: Upper Three Runs Creek (Site 2)

County: Aiken, SC

Collection Date: 5 Nov - 8 Dec 1997

Site / \# of Organisms

\begin{tabular}{|c|c|c|c|c|c|c|c|c|c|}
\hline ORDER.TRICHOPTERA (caddisflies) & 26 & Sep & 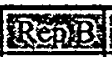 & REp & (2epta & Rep Fif & getion: & 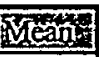 & Qulition \\
\hline Brachycentrus numerosus & $\mathbf{L}$ & 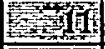 & 의 & 0 & 6 & 0 & 8 & 3.4 & Pats \\
\hline Cheumatopsyche & $\mathbf{L}$ & 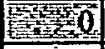 & 1 & 1 & 0 & 0 & 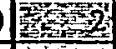 & 0.4 & 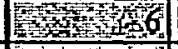 \\
\hline Chimarra aterrima & L & S & 0) & 0 & 0 & 0 & 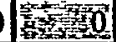 & $\mathbf{0}$ & Hes \\
\hline Hydropsyche elissoma & $\mathbf{L}$ & Band & 0 & 0 & 0 & $\overline{0}$ & 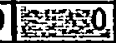 & $\overline{0}$ & 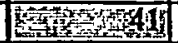 \\
\hline Micrasema nr. rusticum & $\mathbf{L}$ & 97 & 0| & 0 & 0 & 0 & 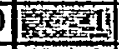 & 0.2 & 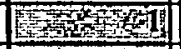 \\
\hline Neureclipsis & $\mathbf{L}$ & 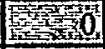 & 0 & 0 & 0 & 0 & 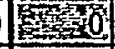 & 0 & 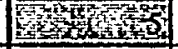 \\
\hline Paranyctiophylax & $\mathrm{L}$ & 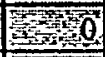 & 0 & 0 & 0 & 0 & 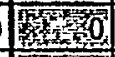 & 0 & 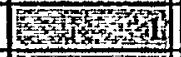 \\
\hline Phylocentropus & $\mathbf{L}$ & 19. & 0 & 0 & 0 & 0 & 130 & 0 & 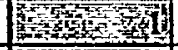 \\
\hline Pycnopsyche sp. & $\mathbf{L}$ & Pris & 0 & 0 & 0 & 0 & 50 & 0 & 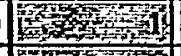 \\
\hline Tricenodes & L & 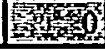 & 0 & 0 & 0 & $\underline{0}$ & 19: & 0 & 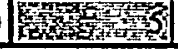 \\
\hline
\end{tabular}

\begin{tabular}{|c|c|c|c|c|c|c|c|c|c|}
\hline ORDER ODONATA (dragonflies) & tage & Rep & Repis & Red & Rep & Bep & Fisting & 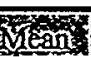 & Qinalution \\
\hline Boyeria vinosa & $\mathbf{N}$ & 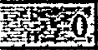 & 0 & 0 & 0 & 0 & $370^{\circ}$ & 0 & 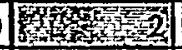 \\
\hline Calopteryx dimidiata & $\mathbf{N}$ & 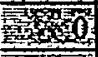 & 0 & 이 & 0 & 0 & 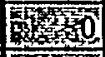 & $\underline{0}$ & 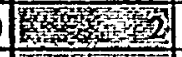 \\
\hline Gomphus lividus & $\mathbf{N}$ & 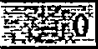 & 0 & 0 & 0 & 0 & 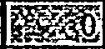 & $\mathbf{0}$ & 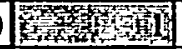 \\
\hline Libellula & $\mathrm{N}$ & 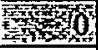 & 0 & 0 & 0 & 0 & 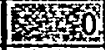 & $\underline{0}$ & 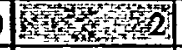 \\
\hline Macromia georgina / illinoiensis & $\mathrm{N}$ & 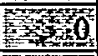 & 0 & 0 & 0 & 0 & 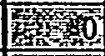 & $\underline{0}$ & 19 \\
\hline Neurocordulia virginiensis & $\mathbf{N}$ & 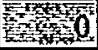 & 0 & 0 & 0 & 0 & 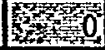 & 0 & Exts \\
\hline
\end{tabular}

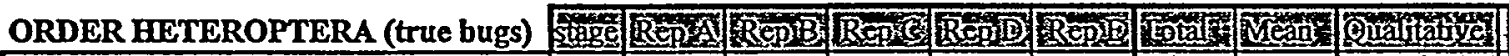

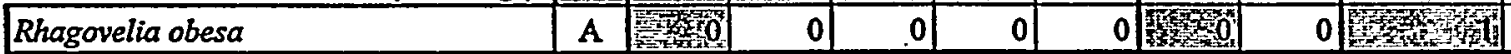


Appendix Table B-3. Macroinvertebrate Data, by Replicate

Client: Westinghouse Savannah River Company

Stream: Upper Three Runs Creek (Site 3)

County: Aiken, SC

Collection Date: 5 Nov - 8 Dec 1997

Site /\# of Organisms

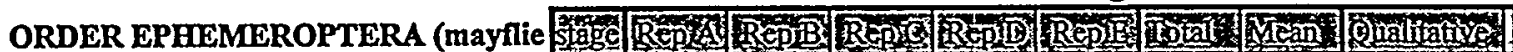

\begin{tabular}{|c|c|c|c|c|c|c|c|c|c|}
\hline Baetis dubium & $\mathbf{N}$ & 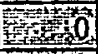 & 0 & 0 & 0 & 0 & 5 & 0 & 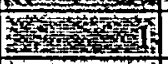 \\
\hline Baetis frondalis & $\mathbf{N}$ & 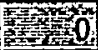 & 0 & 0 & 0 & $\overrightarrow{0}$ & 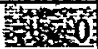 & 0 & 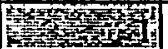 \\
\hline Habrophlebia vibrans & $\mathbf{N}$ & $\sqrt{10}$ & 1 & 0 & 0 & 0 & 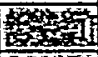 & 0.2 & 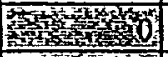 \\
\hline Hexagenia limbata & $\mathrm{N}$ & 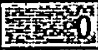 & 0 & 0 & 0 & 0 & 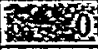 & 0 & 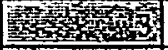 \\
\hline Neoephemera youngi & $\mathrm{N}$ & 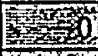 & 0 & 0 & $\underline{0}$ & 0 & 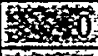 & 0 & 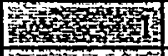 \\
\hline Stenonema modestum/smithae & $\mathrm{N}$ & 留 & 0 & 4 & 1 & 1 & 8 & 1.6 & 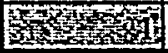 \\
\hline
\end{tabular}

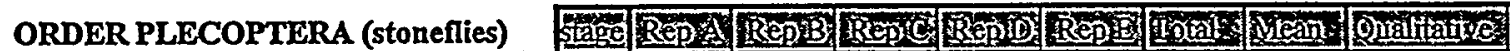

\begin{tabular}{|c|c|c|c|c|c|c|c|c|c|}
\hline Acroneuria abnormis & $\bar{N}$ & 管 & 0 & 1 & 0 & 1 & Fis & 0.4 & 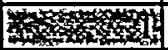 \\
\hline Acroneuria lycorias & $\mathrm{N}$ & 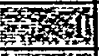 & 4 & 1 & 4 & 0 & ris & 2 & Pring \\
\hline Helopicus subvarians & $\mathbf{N}$ & 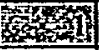 & 0 & 0 & 0 & 1 & 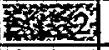 & 0.4 & $5 \times 3 \times 2$ \\
\hline Perlidae & $\mathbf{N}$ & 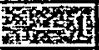 & 0 & 2 & 0 & 1 & 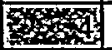 & 0.8 & 18 \\
\hline Paragnetina fumosa & $\mathrm{N}$ & 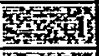 & 0 & 0 & 3 & $\underline{0}$ & 4 & 0.8 & 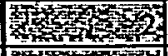 \\
\hline Perlesta placida & $\mathbf{N}$ & 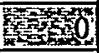 & 0 & 0 & 1 & 2 & 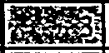 & 0.6 & 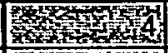 \\
\hline Pteronarcys & $N$ & 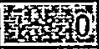 & 0 & 0 & 0 & 0 & 18 & 0 & 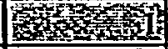 \\
\hline Taeniopteryx metequi & $\mathbf{N}$ & 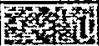 & $\mathbf{0}$ & 1 & $\mathbf{0}$ & 2 & 4 & 0.8 & 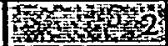 \\
\hline
\end{tabular}


Appendix Table B-3. Macroinvertebrate Data, by Replicate

Client: Westinghouse Savannah River Company

Stream: Upper Three Runs Creek (Site 2)

County: Aiken, SC

Collection Date: 5 Nov - 8 Dec 1997

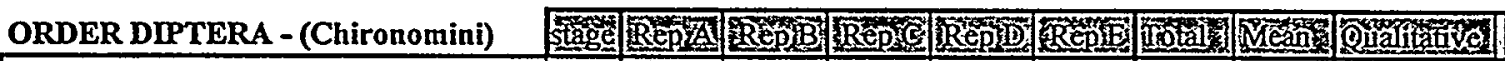

\begin{tabular}{|c|c|c|c|c|c|c|c|c|c|}
\hline Cryptochironomus fulvus gp. & $\mathrm{L}$ & 40 & 0 & 0 & 0 & 0 & 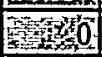 & 0 & $8 y$ \\
\hline Microtendipes nr. pedellus & $\mathrm{L}$ & S0 & 0 & 0 & 0 & $\underline{0}$ & 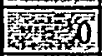 & 0 & trtint \\
\hline Microtendipes nr. rydalensis & $\mathbf{L}$ & Fen & 2 & 2 & 0 & 0 & 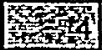 & 0.8 & 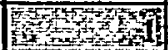 \\
\hline Nilothauma & $\underline{L}$ & 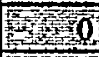 & 0 & 0 & 0 & 0 & 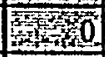 & 0 & tivers \\
\hline Paralauterborniella nigrohalteralis & $\mathbf{L}$ & 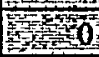 & 0 & 0 & 0 & 0 & Fis & 0 & 地? \\
\hline Polypedilum aviceps & $\mathrm{L}$ & 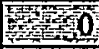 & 2 & 5 & 0 & 0 & 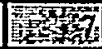 & 1.4 & F⿻上丨 \\
\hline Polypedilum illinoense & $L$ & 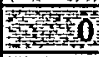 & 0 & $\mathbf{0}$ & 0 & 0 & X & 0 & 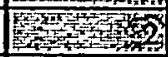 \\
\hline Polypedilum fallax & $\mathrm{L}$ & 5 & 0 & 2 & 0 & $\overline{0}$ & Ing & $\overline{0.4}$ & \\
\hline
\end{tabular}

\begin{tabular}{|c|c|c|c|c|c|c|c|c|c|}
\hline ORDER DIPTERA - (Tanytarsini) & 5 & Rep 践 & $\operatorname{RepB}$ & Repic & 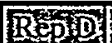 & Sep & 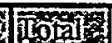 & 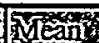 & 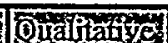 \\
\hline Paratanytarsus & $\mathrm{L}$ & 䇺 & 1 & 0 & 0 & 0 & 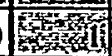 & 0.2 & $x+8 x^{2}$ \\
\hline Rheotanytarsus distinctissimus $g p$. & L & ristint & 1 & 5 & 3 & I & ry & 2.2 & 15 \\
\hline Rheotanytarsus exigurus gp. & L & 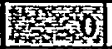 & 0 & 0 & 0 & 0 & 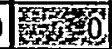 & $\overline{0}$ & 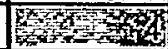 \\
\hline Tanytarsus & $\mathbf{P}$ & 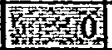 & $\overline{0}$ & 0 & 0 & 0 & 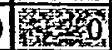 & & 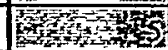 \\
\hline
\end{tabular}

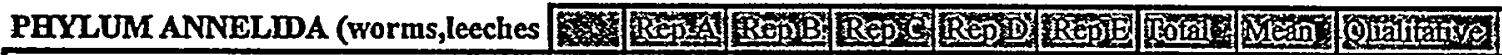

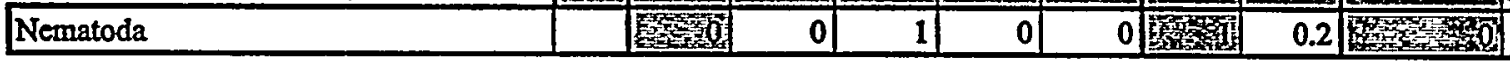

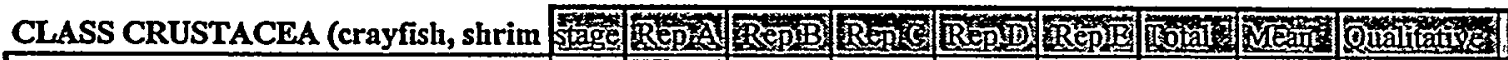

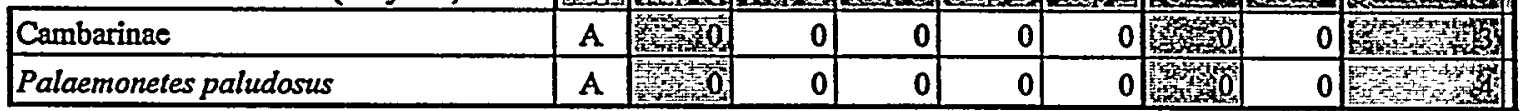

ORDER LEPDOPTERA (moths)

Parapoynx obscuralis

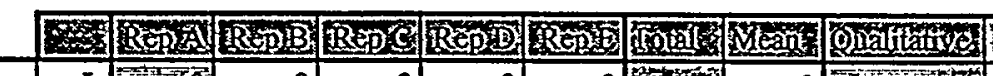

PHYLUM MOLLUSCA (clams, snails) WX Bep

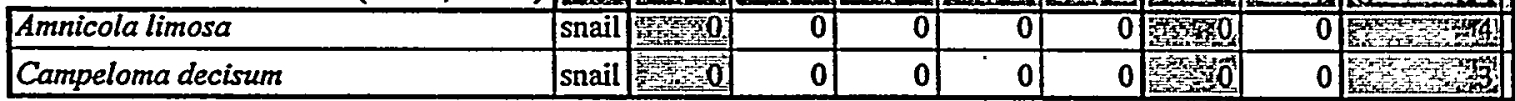


Appendix Table B-3. Macroinvertebrate Data, by Replicate

Client: Westinghouse Savannah River Company

Stream: Upper Three Runs Creek (Site 3)

County: Aiken, SC

Collection Date: 5 Nov - 8 Dec 1997

Site /\# of Organisms

ORDER DIPTERA - (Tanypodinae)

Clinotanypus pinguis

Conchapelopia

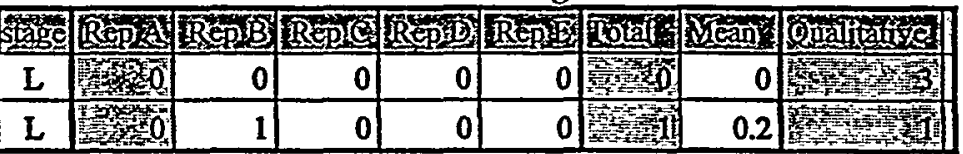

ORDER DIPTERA - (Orthocladiinae)

Nanocladius

Parametriocnemus lundbecki

Rheocricotopus robacki

Tvetenia discoloripes $\mathrm{gp}$.

\begin{tabular}{|c|c|c|c|c|c|c|c|c|}
\hline$a g$ & Repris & Rep & Sep? & Repin & sepir & Tonit? & 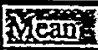 & ofilicatios \\
\hline $\mathbf{L}$ & 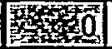 & 0 & 0 & 0 & 0 & 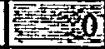 & 0 & (1) \\
\hline,$P$ & Fon & 0 & 0 & 0 & 0 & 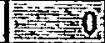 & 0 & 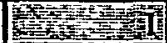 \\
\hline $\mathrm{L}$ & 5 & 1 & 0 & 0 & 1 & 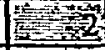 & 0.4 & 150 \\
\hline L & 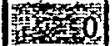 & 0 & 0 & 0 & 1 & $\mid$ & 0.2 & 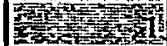 \\
\hline
\end{tabular}

ORDER DIPTERA - (Chironomini)

Microtendipes nr. rydalensis

Polypedilum aviceps

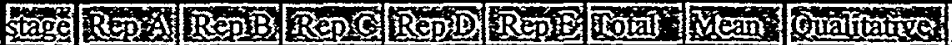

L 5

L

\begin{tabular}{l|l|l|l|}
1 & 1 & 0 & 0 \\
\hline 0 & 0 & 0 & 1 \\
\hline
\end{tabular}

0

0.4 trits

ORDER DIPTERA - (Tanytarsini)

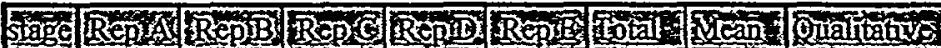

Rheotanytarsus distinctissimus gp.

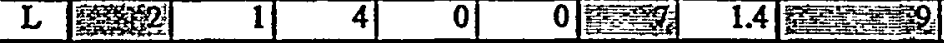

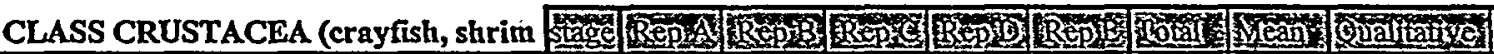

Cambarinae

A ${ }_{2}$

\begin{tabular}{lllll|l}
0 & 0 & 0 & 0 & $B=0$ \\
\hline
\end{tabular}

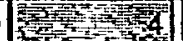

ORDER LEPDOPTERA (moths)

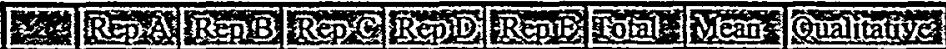

Parapoynx obscuralis

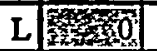

$\begin{array}{lllll}0 & 0 & 0 & 0 & Z_{2}\end{array}$

0 


\section{Appendix Table B-3. Macroinvertebrate Data, by Replicate}

Client: Westinghouse Savannah River Company

Stream: Upper Three Runs Creek (Site 3)

County: Aiken, SC

Collection Date: 5 Nov - 8 Dec 1997

Site /\# of Organisms

\begin{tabular}{|c|c|c|c|c|c|c|c|c|c|}
\hline ORDER TRICE & se & Rep & Rep & Repin & 然面 & 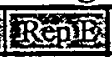 & gara & 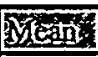 & 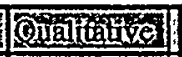 \\
\hline Brachycentrus chelatus & $\mathbf{L}$ & 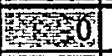 & 0 & 0 & 2 & 6 & 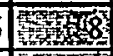 & 1.6 & 46 \\
\hline Cernotina spicata & $\mathbf{L}$ & 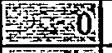 & 0 & 0 & 0 & 0 & W & $\underline{0}$ & \\
\hline Cheumatopsyche & $\mathbf{L}$ & 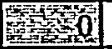 & 0 & 0 & 0 & 2. & 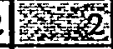 & 0.4 & 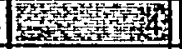 \\
\hline Diplectrona modesta & $\mathbf{L}$ & Ex & 0 & 0) & 0 & & Evis & 0.2 & 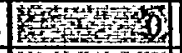 \\
\hline Hydropsyche elissoma & $\mathbf{L}$ & 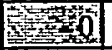 & 0 & 0 & 0 & 6 & 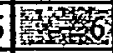 & 1.2 & 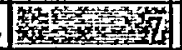 \\
\hline Micrasema nr. rusticum & L & 5 & 0 & 0 & 0 & & 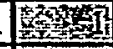 & 0.2 & 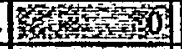 \\
\hline Neureclipsis & $\mathrm{L}$ & 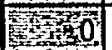 & 0 & 0 & 0 & 0 & 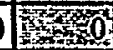 & $\overline{0}$ & 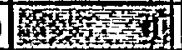 \\
\hline Phylocentropus & $\bar{L}$ & 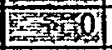 & 0 & 0 & 0 & 2 & 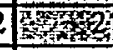 & 0.4 & 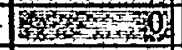 \\
\hline Pycnopsyche sp. & $\overline{\mathrm{L}}$ & 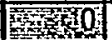 & 0 & 0 & 0 & 0 & 0 & & 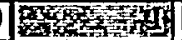 \\
\hline
\end{tabular}

\begin{tabular}{|c|c|c|c|c|c|c|c|c|c|}
\hline ORDER ODONATA (dragonflies) & Eage & BEp & nep & Bepa & Repen & Rep & Tobat & on & Qualtation \\
\hline Argia sp & $\mathrm{N}$ & 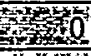 & 0 & of & 0 & $\underline{0}$ & 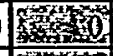 & 0 & 3) \\
\hline Boyeria vinosa & $\bar{N}$ & 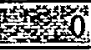 & $\mathbf{0}$ & 0 & 0 & 1 & 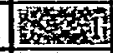 & 0.2 & 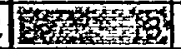 \\
\hline Calopteryx dimidiata & $\mathbf{N}$ & 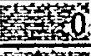 & 0 & 의 & 0 & $\underline{0}$ & 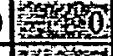 & 0) & 15 \\
\hline Enallagma sp. & $\mathrm{N}$ & 5 & 0 & 0 & $\underline{0}$ & $\underline{0}$ & 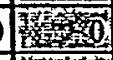 & 0 & 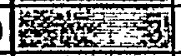 \\
\hline Gomphus (Stylurus) notatus & $\mathbf{N}$ & 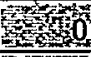 & $\underline{0}$ & 의 & 0 & $\underline{0}$ & 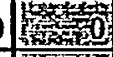 & 0 & 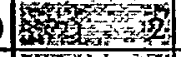 \\
\hline Macromia georgina / illinoiensis & $\mathbf{N}$ & 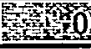 & 0 & 0 & 0 & 0 & 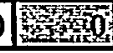 & & 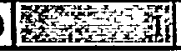 \\
\hline
\end{tabular}

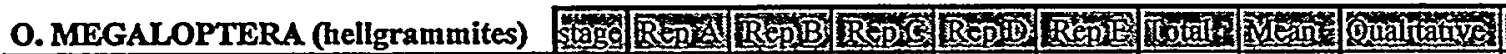

\begin{tabular}{|c|c|c|c|c|c|c|c|c|c|}
\hline Nigronia serricornis & $\mathrm{L}$ & 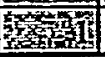 & 0 & 1 & 0 & & 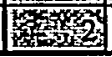 & 0.4 & 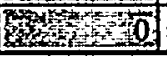 \\
\hline ORDER COLEOPTERA (beetles) & 等数 & Repug & 俩 & Repe & Bepie: & Bepin & 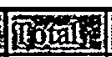 & Ean & 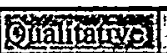 \\
\hline Gonielmis dietrichi & L & 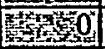 & 0 & 0 & 0 & 0 & 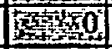 & 0 & 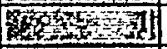 \\
\hline Optioservus & $L$ & 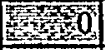 & 0 & 1 & 0 & 0 & 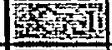 & 0.2 & 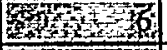 \\
\hline Stenelmis sinuata & $\bar{A}$ & risution & 1 & 0 & 0 & $\overline{0}$ & 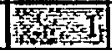 & 0.2 & ont \\
\hline
\end{tabular}

ORDER DIPTERA - other than midges Etage ECP

\begin{tabular}{|c|c|c|c|c|c|c|c|c|c|}
\hline Hemerodromia & $\mathbf{L}$ & Dis & 0 & 0 & 0 & 0 & 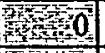 & 0 & 政 \\
\hline Ephydridac & $\mathbf{L}$ & Fiven & 0 & 0 & 0 & 0 & En & 0 & 然 \\
\hline Ectemnia invenusta & $\mathbf{L}$ & 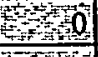 & 0 & 2 & 0 & 3 & 5 & 1 & 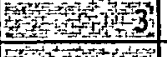 \\
\hline Bezzia & $\mathrm{L}$ & 80 & 0 & 0 & 0 & 0 & into & 0 & $5=24$ \\
\hline Simulium nr. podostemi & $\mathrm{L}$ & 0 & 0 & 0 & 0 & $\underline{0}$ & Ever & 0 & 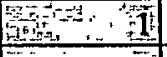 \\
\hline Simulium tuberosum complex & $\mathrm{L}$ & 20 & 0 & 0 & 0 & 2 & $x_{2}$ & 0.4 & E \\
\hline Stilobezzia nr. Iutea & $\mathrm{L}$ & $\because 0$ & 0 & 0 & 0 & $\underline{0}$ & 然 & $\underline{0}$ & 1 \\
\hline
\end{tabular}


Appendix Table B-3. Macroinvertebrate Data, by Replicate

Client: Westinghouse Savannah River Company

Stream: Mill Creek (Site 4)

County: Barnwell, SC

Collection Date: 5 Nov - 8 Dec 1997

Site / \# of Organisms

\begin{tabular}{|c|c|c|c|c|c|c|c|c|c|}
\hline O. MEGALOPTERA (hellgrammites) & stag & Rep & RepB & Reprs & Rep & 需ep & Totar & 1ean & Qualitaver \\
\hline Sialis & $\mathrm{L}$ & 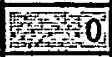 & 0 & 0 & 0 & $\underline{0}$ & S & 0 & 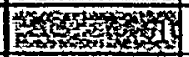 \\
\hline Corydalus cornutus & $\mathrm{L}$ & Fin & 0 & 1 & 0 & $\underline{0}$ & 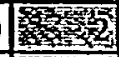 & 0.4 & 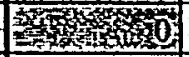 \\
\hline Nigronia serricornis & L & 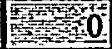 & 0 & 0 & 0 & & 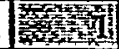 & 0.2 & 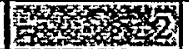 \\
\hline
\end{tabular}

\begin{tabular}{|c|c|c|c|c|c|c|c|c|c|}
\hline ORDER COLEOPTERA (beetles) & state & epen & Repi: & APp & Repin & Repe & Cotail & tean & Qinalitation \\
\hline Dubiraphia sp. & $\mathrm{L}, \mathrm{A}$ & 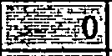 & 0 & 우 & 이 & 0 & 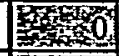 & 0 & 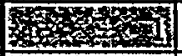 \\
\hline Ectopria nervosa & L & 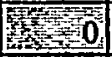 & 이 & 0 & 요 & & 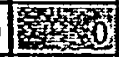 & 0 & 5 \\
\hline Optioservus & $\mathbf{L}$ & 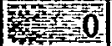 & 0 & $\mathbf{0}$ & 1 & & Esing & 0.2 & 158 \\
\hline
\end{tabular}

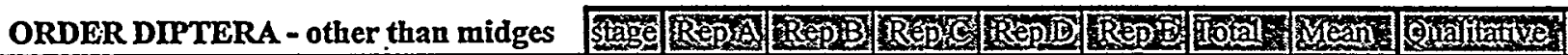

\begin{tabular}{|c|c|c|c|c|c|c|c|c|c|}
\hline Hexatoma & $\mathrm{L}$ & $4=0$ & 0 & 0 & 0 & 0 & 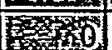 & 0 & (15) \\
\hline Stilobezzia nr. lutea & $\bar{L}$ & 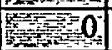 & 0 & 0 & 0 & $\overline{0}$ & 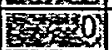 & 0 & 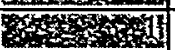 \\
\hline Tipula (Nippotipula) nr. abdominalis & L & 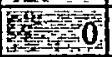 & 0 & 0 & 0 & $\overline{0}$ & Sy & 0 & 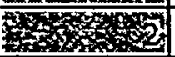 \\
\hline Tipula sp. 2 & $\bar{L}$ & Finto & $\overline{0}$ & 0 & 0 & $\overline{0}$ & 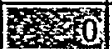 & D & (x) \\
\hline
\end{tabular}

\begin{tabular}{|c|c|c|c|c|c|c|c|c|c|}
\hline ORDER DIPTERA - (Tanypodinae) & Stas: & ep & 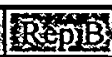 & Reper & 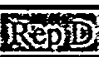 & Sepin & Gotals & Mean & Oralitared \\
\hline Ablabesmyia mallochi & $\mathrm{L}$ & 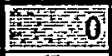 & 0 & 0 & 0 & 0 & 8 & 0 & 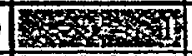 \\
\hline Conchapelopia & $\mathbf{L}$ & 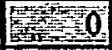 & $\underline{0}$ & 0 & 0 & 1 & 㝡 & 0.2 & 样 \\
\hline Paramerina & L & men & 0 & 1) & 0 & 0 & 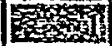 & 0.2 & 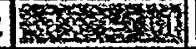 \\
\hline
\end{tabular}

ORDER DIPTERA - (Orthocladiinae)

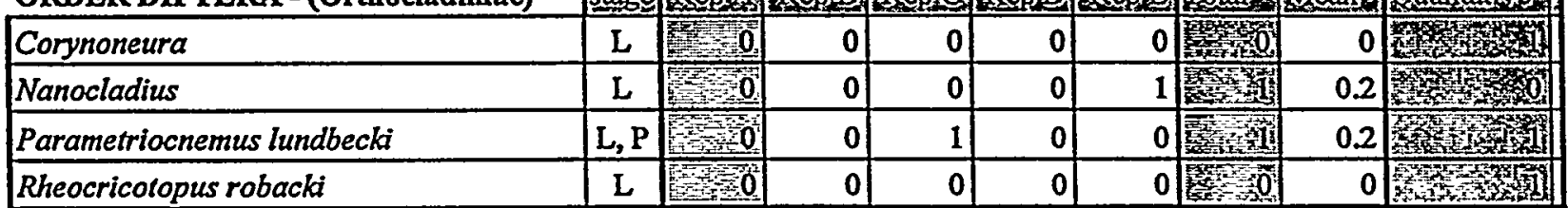

ORDER DIPTERA - (Chironomini)

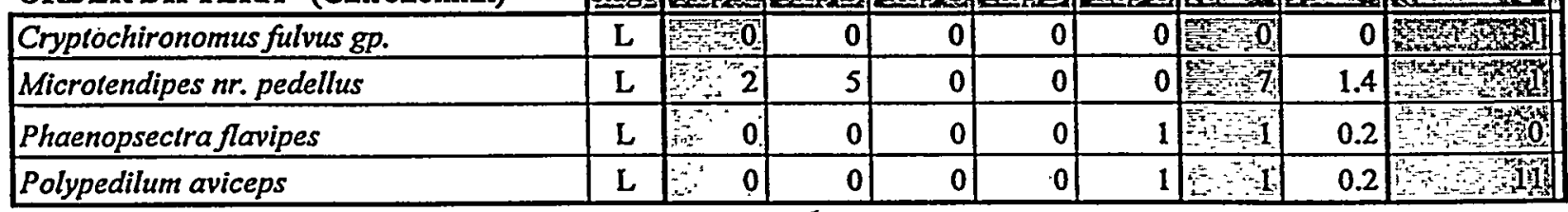


Appendix Table B-3. Macroinvertebrate Data, by Replicate

\author{
Client: Westinghouse Savannah River Company \\ Stream: Mill Creek (Site 4) \\ County: Barnwell, SC \\ Collection Date: 5 Nov - 8 Dec 1997
}

Site / \# of Organisms

\begin{tabular}{|c|c|c|c|c|c|c|c|c|c|}
\hline ORDER EPHEMEROPTERA (mayflies) & stage & Bep & Rep & Rep & Repi国 & Repte & Itotal & tean & Qualitaty \\
\hline Eurylophella (immature / damaged) & $\mathbf{N}$ & Prot & 0 & $\underline{0}$ & 0) & & VII & 0.2 & $\sqrt{12 x}$ \\
\hline Hexagenia limbata & $\mathrm{N}$ & 10 & 이 & $\mathbf{0}$ & 이 & 0 & 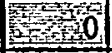 & 0 & (3) \\
\hline Paraleptophlebia & $N$ & S15 & 0] & 0 & 0 & $\underline{0}$ & 72 & 0.4 & Ex \\
\hline Stenonema modestum/smithae & $\mathbf{N}$ & Ty & $8 \mid$ & 8 & 12 & 14 & 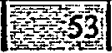 & 10.6 & \\
\hline
\end{tabular}

ORDER PLECOPTERA (stoneflies)

\begin{tabular}{|c|c|c|c|c|c|c|c|c|c|}
\hline Acroneuria mela & $\mathrm{N}$ & W & 0 & 0 & 0 & 0 & 0 & 0 & 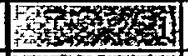 \\
\hline Allocapnia & $\mathrm{N}$ & 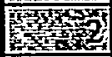 & 5 & 8 & 1 & 3 & $3 \sqrt{19}$ & 3.8 & fon \\
\hline Clioperla clio. & $\mathrm{N}$ & 18 & 1 & 0 & 1 & 0 & 02 & 0.4 & 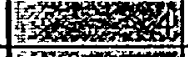 \\
\hline Perlesta placida & $\mathbf{N}$ & W & $\underline{0}$ & 0 & 0 & 1 & $1 \geq 1$ & 0.2 & 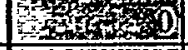 \\
\hline Taeniopteryx metequi & $N$ & 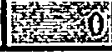 & 0 & 0 & 0 & 0 & 00 & 0 & 10, \\
\hline
\end{tabular}

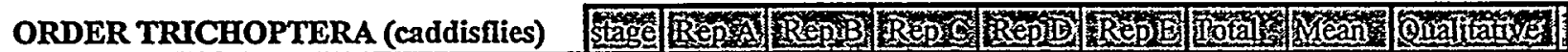

\begin{tabular}{|c|c|c|c|c|c|c|c|c|c|}
\hline Anisocentropus pyraloides & L & 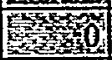 & 0 & 0 & 0 & 0 & 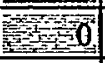 & $\underline{0}$ & 垔 \\
\hline Ceraclea nr. resurgens & $\mathrm{L}$ & 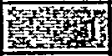 & 0 & 0 & 0 & 0 & 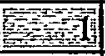 & 0.2 & 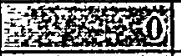 \\
\hline Lype diversa & $\mathrm{L}$ & 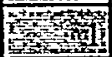 & 0 & 0 & 0 & 0 & Pin & 0.2 & 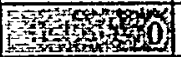 \\
\hline Paranyctiophylax & $\mathrm{L}$ & 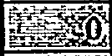 & 0 & 2 & 1 & 0 & +3 & 0.6 & 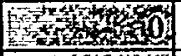 \\
\hline Phylocentropus & $\mathrm{L}$ & 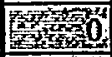 & 0 & 0 & 0 & 0 & Pring & 0 & 整 \\
\hline Triaenodes & $\bar{L}$ & 然 & 0 & $\overline{0}$ & 0 & 0 & 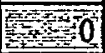 & $\overline{0}$ & 17n \\
\hline
\end{tabular}

\begin{tabular}{|c|c|c|c|c|c|c|c|c|c|}
\hline ORDER ODONATA (dragonflies) & Stage & Rep & ReB & Bepic & Repig & 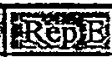 & 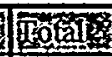 & M & Qualifinge; \\
\hline Boyeria vinosa & $\mathbf{N}$ & 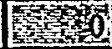 & 0 & 1 & 0 & 0 & PIT & 0.2 & 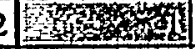 \\
\hline Calopteryx dimidiata & $N$ & 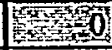 & 0 & 0 & 0 & 0 & Ex: & & 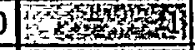 \\
\hline Cordulegaster sp. & $\overrightarrow{\mathrm{N}}$ & P & 0 & 0 & 0 & 0 & 0 & & Phes \\
\hline Enallagma sp. & $\bar{N}$ & 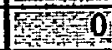 & 0 & $\overline{0}$ & 0 & $\overline{0}$ & $\sqrt{30}$ & 0 & 0 Find \\
\hline Gomphus rogersi & $\mathbf{N}$ & Evis & 0 & 0 & 0 & 0 & 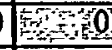 & 0 & 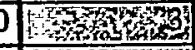 \\
\hline Gomphus lividus & $\mathbf{N}$ & 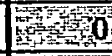 & 0 & 0 & 0 & 0 & 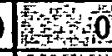 & . 0 & $0]$ \\
\hline Lanthus vernalis & $\mathrm{N}$ & Find & 0 & 0 & 0 & 0 & 0 & $\mathbf{0}$ & 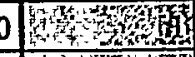 \\
\hline Macromia georgina / illinoiensis & $\mathrm{N}$ & $7+0$ & 0 & 0 & 0 & 0 & $F=0$ & 0 & 0 \\
\hline
\end{tabular}


Appendix Table B-3. Macroinvertebrate Data, by Replicate

\author{
Client: Westinghouse Savannah River Company \\ Stream: McQueen Branch (Site 5) \\ County: Aiken, SC \\ Collection Date: 5 Nov - 8 Dec 1997
}

Site / \# of Organisms

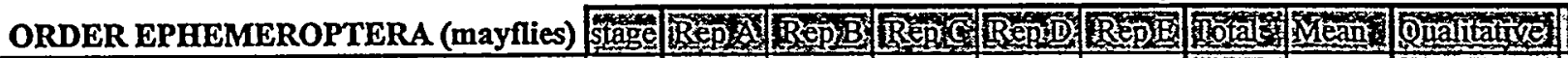

\begin{tabular}{|c|c|c|c|c|c|c|c|c|}
\hline Baetis intercalaris & $\mathbf{N}$ & 0 & 0 & 0 & 0 & 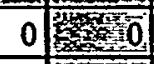 & & 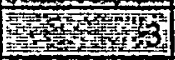 \\
\hline Stenonema modestum/smithae & $\mathrm{N}$ & Pas & 9 & 0 & 4 & 9 焉㧼 & 6.2 & 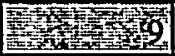 \\
\hline
\end{tabular}

\begin{tabular}{|c|c|c|c|c|c|c|c|c|c|}
\hline ORDER PLECO & Stage & Rep & $\bar{B}$ & Rep & (xepio & Sep & 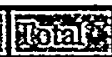 & Meân & Qúlitatice \\
\hline Acroneuria mela & $\bar{N}$ & 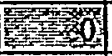 & 0 & 0 & 0 & 0 & $=0$ & 0 & 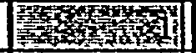 \\
\hline Allocapnia & $\mathbf{N}$ & riving & 0 & .0 & 0 & 1 & S3 & 0.6 & W \\
\hline Clioperla clio & $\mathbf{N}$ & 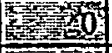 & 0 & 0 & 0 & $\underline{0}$ & 整0 & $\underline{0}$ & 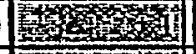 \\
\hline Perlesta placida & $\bar{N}$ & 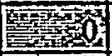 & 1 & 0 & 0 & $\underline{0}$ & 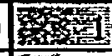 & 0.2 & 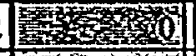 \\
\hline Taeniopteryx metequi & $\mathbf{N}$ & 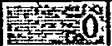 & 0 & 0 & 0 & 0 & 0 & & 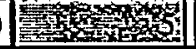 \\
\hline
\end{tabular}

\begin{tabular}{|c|c|c|c|c|c|c|c|c|c|}
\hline ORDER TRICHOPTERA (caddisflies)' & statage & Rept & Rep & Rer & Repio & Repin & Totan & 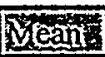 & Qualifative \\
\hline Anisocentropus pyraloides & $\mathrm{L}$ & 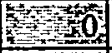 & 0 & 요 & 0 & 0 & 0 & 0 & \\
\hline Cheumatopsyche & $\mathrm{L}$ & 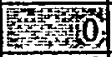 & 0 & 0 & 1 & 0 & 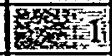 & 0.2 & 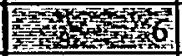 \\
\hline Diplectrona modesta & $\mathrm{L}$ & Ing & 0 & 0 & 0 & 0 & 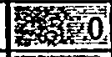 & $\underline{0}$ & 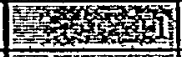 \\
\hline Hydropsyche betteni & $\mathrm{L}$ & 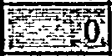 & 0 & 0 & 0 & 0 & 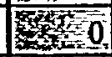 & 0 & 7. \\
\hline Lype diversa & $\underline{L}$ & Plats & 1 & 1 & $\underline{0}$ & 1 & 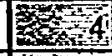 & 0.8 & H \\
\hline Phylocentropus & $\mathrm{L}$ & 50 & 인 & 0 & 0 & 0 & 算 & 0 & 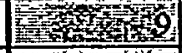 \\
\hline Psilotreta sp. & $\mathrm{L}$ & 10 & 0 & 0 & 0 & 0 & $13=0$ & 0 & 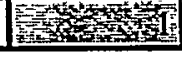 \\
\hline
\end{tabular}

\begin{tabular}{|c|c|c|c|c|c|c|c|c|c|}
\hline ORDER ODONATA (dragonflies) & Stage & Rep & Repis: & ates & Bep & Repi: & 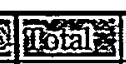 & Meant & Qualitifite \\
\hline Boyeria vinosa & $\mathrm{N}^{\prime}$ & 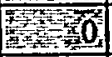 & 0 & 0 & 0 & 0 & 0 & 0 & 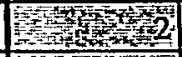 \\
\hline Calopteryx dimidiata & $\mathbf{N}$ & Fin & 0 & 0 & 0 & 0 & 0 & 0 & 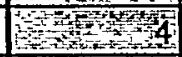 \\
\hline Cordulegaster sp. & $\mathrm{N}$ & $B=0$ & 0 & 0 & 0 & 0 & 0 & 0 & Wy \\
\hline Gomphus (Stylurus) notatus & $\mathbf{N}$ & $E^{2}$ & 0 & 0 & 0 & 0 & 0 & 0 & P3? \\
\hline Ophiogomphus mainensis & $\bar{N}$ & Pation & $\overline{0}$ & 0 & 0 & 0 & $0 \longdiv { 8 0 }$ & 0 & PrT \\
\hline Progomphus & $\overline{\mathbf{N}}$ & 20 & $\overline{0}$ & 0 & 0 & & $0 \longdiv { \text { Far } } 0$ & 0 & 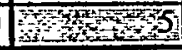 \\
\hline
\end{tabular}

ORDER HETEROPTERA (true bugs)

Rhagovelia obesa

stag [Eep A 10 
Appendix Table B-3. Macroinvertebrate Data, by Replicate

Client: Westinghouse Savannah River Company

Stream: Mill Creek (Site 4)

County: Barnwell, SC

Collection Date: 5 Nov - 8 Dec 1997

Site / \# of Organisms

\begin{tabular}{|c|c|c|c|c|c|c|c|c|}
\hline ORDER DIPTERA - (Tanytarsini) & stag & Reper & RepB & Reptc & Reping. & Rept & 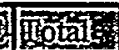 & 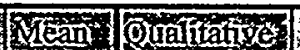 \\
\hline Rheotanytarsus distinctissimus gp. & L & S17. & 0 & 0 & 0 & 0 & 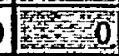 & 0 \\
\hline Tanytarsus & L & Pon & 0 & 0 & 0] & 0 & 0 & 0 \\
\hline
\end{tabular}

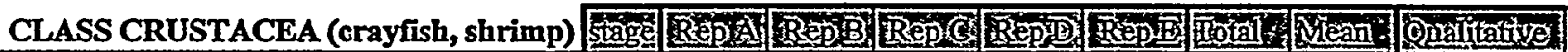

\begin{tabular}{|c|c|c|c|c|c|c|c|c|}
\hline Cambarinae & A & 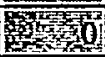 & 0 & 0 & 0 & 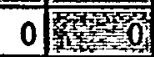 & $\overrightarrow{0}$ & (6) \\
\hline Palaemonetes paludosus & A & 16) & 0 & 0 & 0 & 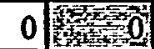 & 0 & 空 \\
\hline
\end{tabular}

\begin{tabular}{|c|c|c|c|c|c|c|c|c|c|}
\hline PHYLUM MOLLUSCA (clams, snails) & 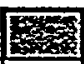 & 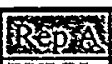 & Beppin & Repic & Eepin & 垔ep & istar & Fean & Cialtation \\
\hline Campeloma decisum & snail & 10 & 이 & 0 & 0 & 0 & 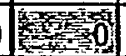 & 0 & (6) \\
\hline Corbicula fluminea & clam & (6) & 0 & 0 & 0 & 0 & (1) & 0 & (5) \\
\hline
\end{tabular}


Appendix Table B-3. Macroinvertebrate Data, by Replicate

Client: Westinghouse Savannah River Company

Stream: McQueen Branch (Site 5)

County: Aiken, SC

Collection Date: 5 Nov - 8 Dec 1997

Site / \# of Organisms

\begin{tabular}{|c|c|c|c|c|c|c|c|c|c|}
\hline O. MEGALOPTERA (hellgrammites) & stage & Repry & Repi & Repla & Bepis & Sep & Sotaty & Seant & Qualifarte \\
\hline Corydalus cornutus & $\mathrm{L}$ & Pat & 0 & 0 & 0 & 0. & 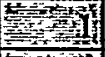 & 0.2 & Prons \\
\hline Nigronia serricornis & $\mathbf{L}$ & 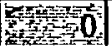 & 1 & 01 & 0 & 0 & 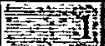 & 0.2 & Fing \\
\hline
\end{tabular}

ORDER COLEOPTERA (beetles)

Anchytarsus bicolor

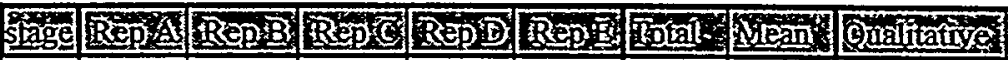

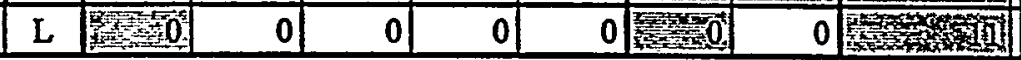

ORDER DIPTERA - other than midges

Genus nr. Cryptolabis

Tipula sp.

Tipula sp. 2

\begin{tabular}{|c|c|c|c|c|c|c|c|c|}
\hline stage & Rep & (cep & Reps & Sep & Sepie & bat. & Tenin & Quir \\
\hline$L$ & 850 & 0 & 0 & 이 & 0 & V) & 0 & 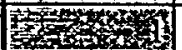 \\
\hline $\mathrm{L}$ & 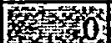 & 0 & 이 & 0 & 0 & 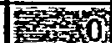 & $\overline{0}$ & (1) \\
\hline $\bar{L}$ & 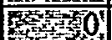 & 0 & 0 & $\overline{0}$ & $\overline{0}$ & (5) & $\overline{0}$ & 厓 \\
\hline
\end{tabular}

ORDER DIPTERA - (Tanypodinae)

Paramerina

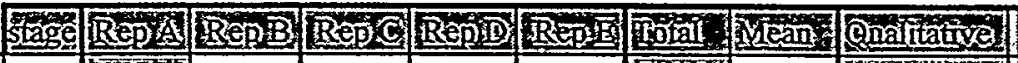

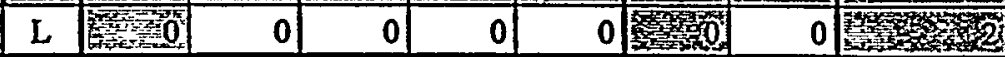

ORDER DIPTERA - (Orthocladiinae)

(Diamesinae)-Potthastia longimana

Nanocladius

Parametriocnemus lundbecki

Rheocricotopus robacki

Thienemanniella xena gp.

\begin{tabular}{|c|c|c|c|c|c|}
\hline tage & Bes & Bep & $\mathrm{ReD}$ & Sep & Rep \\
\hline L & VI & 0 & 0 & 0 & 0 \\
\hline L & 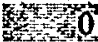 & 1 & 0 & 0 & 0 \\
\hline$L, P$ & 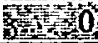 & 0 & 2 & 1 & 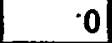 \\
\hline L & WI & 0 & 0 & 0 & 0 \\
\hline L & $m^{2} 3$ & 0 & 0 & 1 & 0 \\
\hline
\end{tabular}

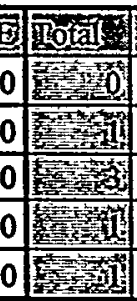

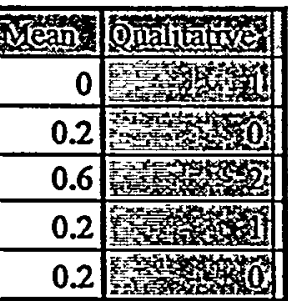

ORDER DIPTERA - (Chironomini)

Polypedilum aviceps

Stage Rep

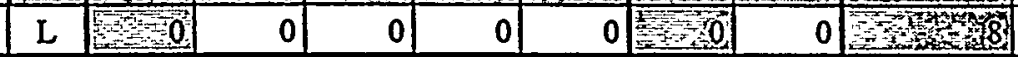

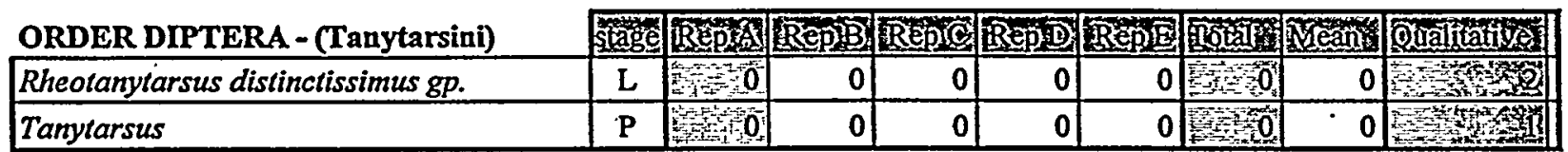

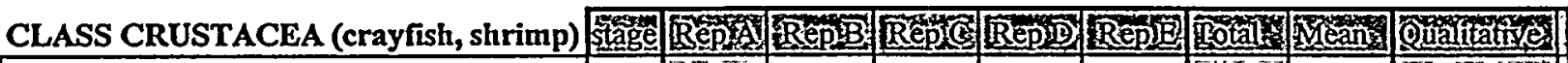
Palaemonetes paludosus $\begin{array}{lllllll}A & 0 & 0 & 0 & 0 & 0 & 0\end{array}$

PHYLUM MOLLUSCA (clams, snails) Campeloma decisum

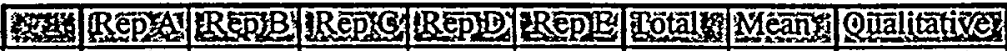

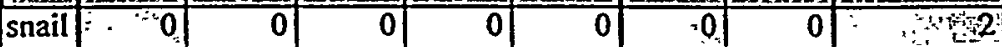


Appendix Table B-3. Macroinvertebrate Data, by Replicate

\section{Client: Westinghouse Savannah River Company}

Stream: Crouch Branch (Site 6)

County: Barnwell, SC

Collection Date: 5 Nov - 8 Dec 1997

Site / \# of Organisms

\begin{tabular}{|c|c|c|c|c|c|c|c|c|c|}
\hline ORDER ODONATA (dragonflies) & tage & Repis & Bepie & Resces & RepiD & Repin & 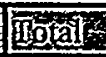 & Tean & 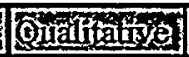 \\
\hline$\longdiv { \text { Argia sedula } }$ & $\mathbf{N}$ & 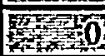 & 0 & $\overline{0}$ & $\overline{0}$ & & 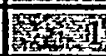 & 0.2 & 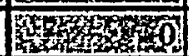 \\
\hline Enallagma sp. & $\mathbf{N}$ & 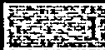 & 0 & 0 & 0 & & 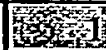 & 0.2 & 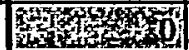 \\
\hline
\end{tabular}

ORDER DIPTERA - other than midges Stage Rep

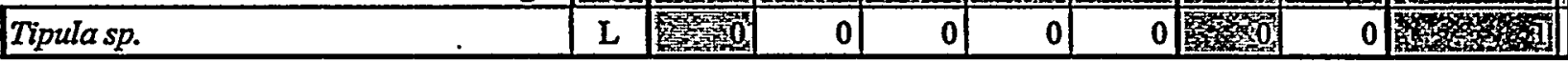

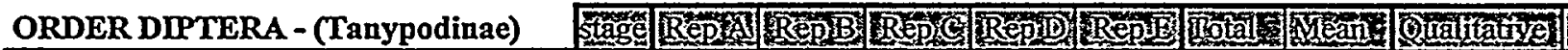

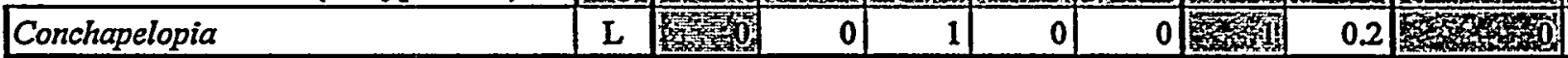

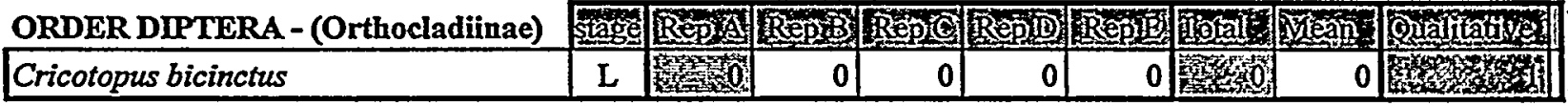

\begin{tabular}{|c|c|c|c|c|c|c|c|c|c|}
\hline ORDER DIPTERA - (C) & tage & Repsa & SepB & Repese & Rep & $\overline{\mathrm{Rep} T \mathrm{~B}}$ & Fotain & Yean & Qualitative \\
\hline Phaenops & $\mathrm{L}$ & Sula & 0 & $\overline{0}$ & 1 & 3 & $\sqrt{3 x}$ & 0.8 & 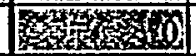 \\
\hline Polypedilum fallox & L & 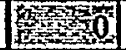 & 0 & 0 & 0 & & 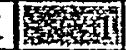 & 0.2 & 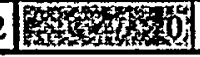 \\
\hline
\end{tabular}

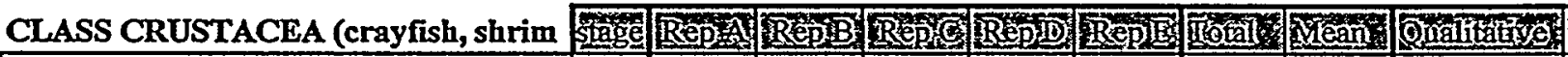
Cambarinae

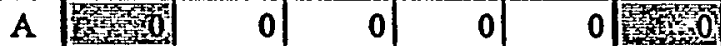

mitos 
Appendix Table B-3. Macroinvertebrate Data, by Replicate

Client: Westinghouse Savannah River Company

Stream: Four Mile Branch (Site 8)

County: Barnwell, SC

Collection Date: 5 Nov - 8 Dec 1997

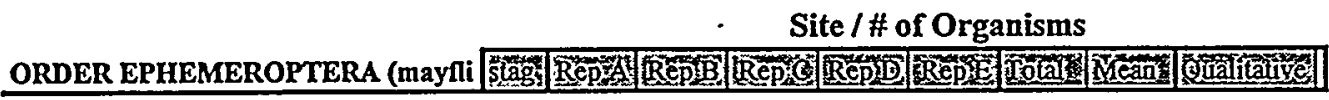

Site /\# of Organisms

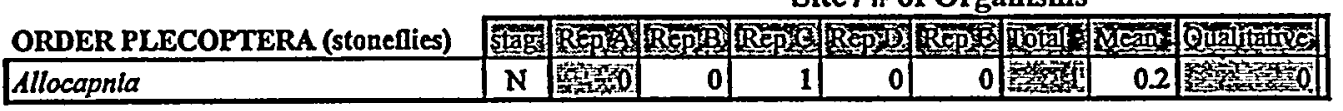

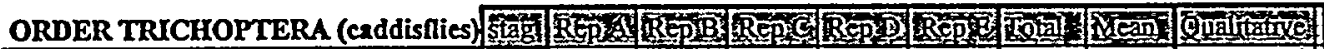

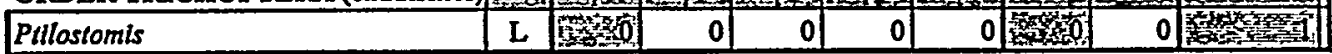

\begin{tabular}{|c|c|c|c|c|c|c|c|c|c|}
\hline ORDER ODONATA (dragonflies) & siag & Bep & $\overline{\mathrm{A}}$ & Rिing & Repre & $\sqrt{\text { Bephe }}$ & 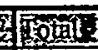 & Men & Qhinitine \\
\hline Calopleryx dimidiala & $\mathbf{N}$ & 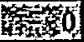 & 0 & of & o & & 1) & 0.2 & 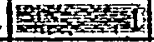 \\
\hline Cordulegaster sp. & $\mathbf{N}$ & Sist & $\underline{0}$ & 0 & 0 & $\mathbf{0}$ & 0 & & 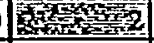 \\
\hline Enallagma sp. & $\mathbf{N}$ & 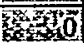 & $\mathbf{0}$ & 0 & 0 & & 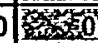 & & Ag \\
\hline
\end{tabular}

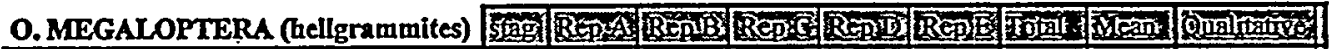

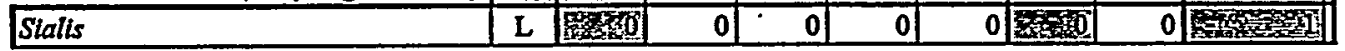

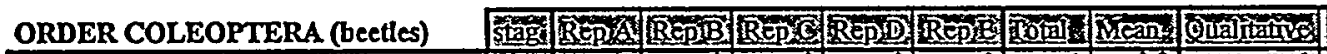

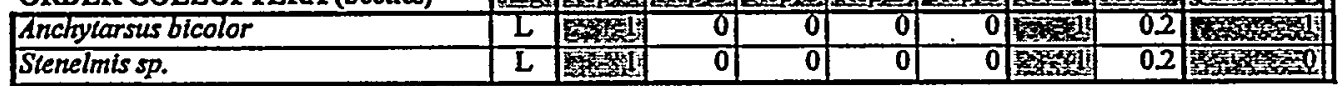

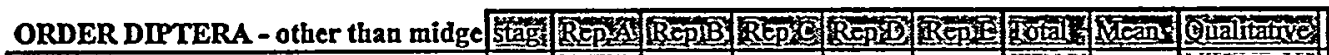

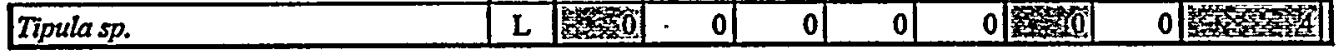

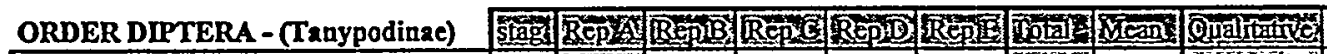

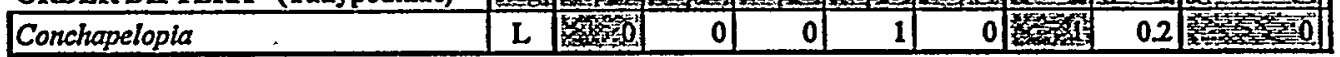

\begin{tabular}{|c|c|c|c|c|c|c|c|c|c|}
\hline ORDER DIPTER & 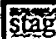 & Rep & 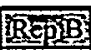 & $\longdiv { \operatorname { R e p s } ^ { 2 } }$ & Eep & Rep & & Mean & \\
\hline Genus nr. Nanocladius B & $\mathrm{L}$ & 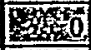 & 0 & 0 & 0 & & 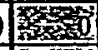 & & 0 \\
\hline Klefferulus dux & $\bar{L}$ & S & $\overline{0}$ & 0 & 0 & & 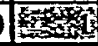 & 0.2 & 2 \\
\hline
\end{tabular}

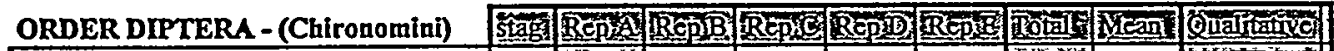

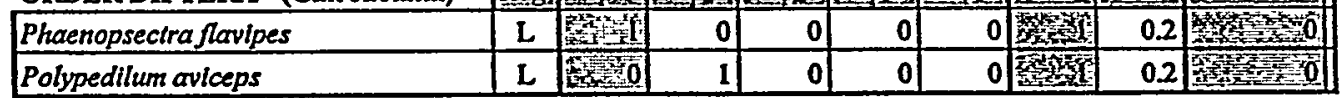

ORDER DIPTERA - (Tanytarsini) TLä REp

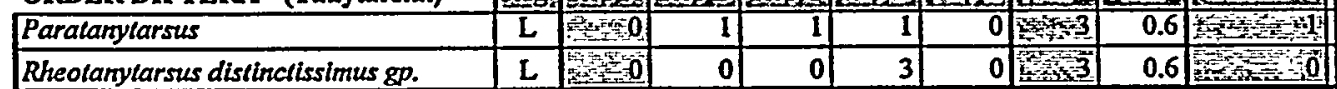

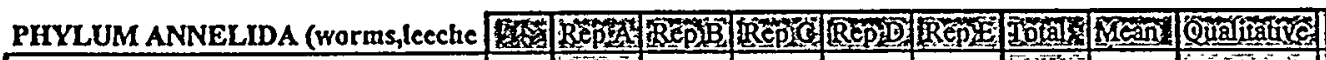

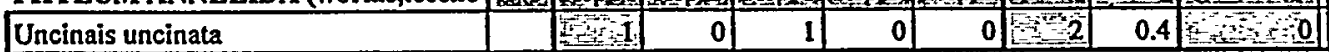

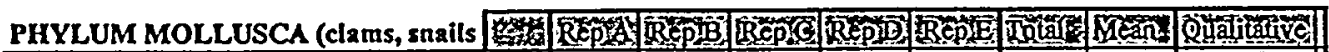
Campeloma decisum Sphaerium

\begin{tabular}{|c|c|c|c|c|c|c|c|}
\hline ail 0 & 0 & $\underline{0}$ & 0 & & 000 & & 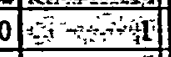 \\
\hline & 0 & 0 & 0 & 0 & $\because 0$ & 0 & $\mathbf{1}$ \\
\hline
\end{tabular}


Appendix Table B-3. Macroinvertebrate Data, by Replicate

Client: Westinghouse Savannah River Company

Stream: Four Mile Branch (Site 7)

County: Barnwell, SC

Collection Date: 5 Nov - 8 Dec 1997

Site / \# of Organisms

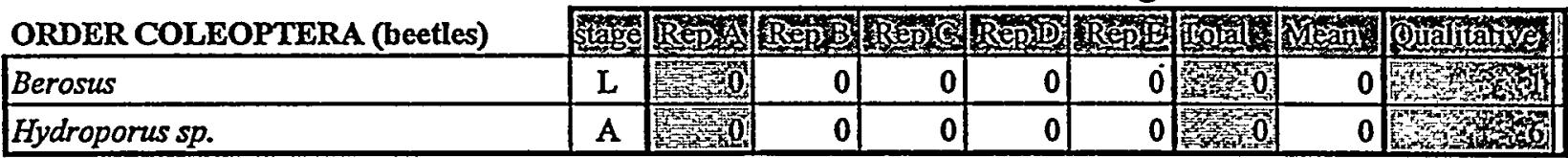

\begin{tabular}{|c|c|c|c|c|c|c|c|c|c|}
\hline ORDER DIPTERA - other than midges & stage & 営 & B. & Bepent & Repin & Sep & 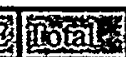 & Mean & oulutiva \\
\hline Crysc & $L$ & 14 & 0 & 0 & 0 & & 18 & 0.2 & 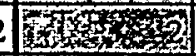 \\
\hline Pilaria & $\bar{L}$ & 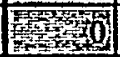 & 0 & 0 & 0 & & $0 \longdiv { 1 7 }$ & & 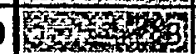 \\
\hline
\end{tabular}

ORDER DIPTERA - (Tanypodinae)

Ablabesmyia nr. peleensis

Clinotanypus pinguis

Procladius

Tamjpus punctipennis

\begin{tabular}{|c|c|c|c|c|c|c|c|c|}
\hline Stage & Reps & Reps: & Rep & Rep & Rep & atain & Mean & Quthoplo \\
\hline L & 15iva & 0 & $\overline{0}$ & 0 & 0 & 20040 & 0 & ren \\
\hline $\bar{L}$ & 180 & 0 & $\overline{0}$ & $\overline{0}$ & $\overline{0}$ & 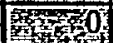 & 0 & 及 \\
\hline L & 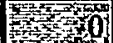 & 0 & 0 & 0 & 0 & 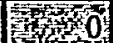 & 0 & Hom \\
\hline $\mathbf{L}$ & 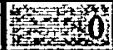 & 0 & 0 & 0 & 0 & B & 0 & 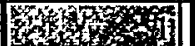 \\
\hline
\end{tabular}

\begin{tabular}{|c|c|c|c|c|c|c|c|c|c|}
\hline ORDER DIPTERA - (Orthocladiinae) & 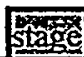 & Rep & Rep B & Beps & ep & Rep & intolis & Mean & Orialit? \\
\hline Psend & $\mathbf{L}$ & 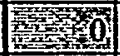 & 0 & 0 & 0 & 0 & 20 & & 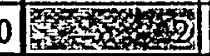 \\
\hline Tvetenia discoloripes $\mathrm{g}$ & $\mathrm{L}$ & 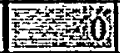 & 0 & 0 & 1 & & & 0. & 50 \\
\hline
\end{tabular}

ORDER DIPTERA - (Chironomini)

\begin{tabular}{|c|c|c|c|c|c|c|c|c|c|}
\hline Chironomus & $\mathbf{L}$ & 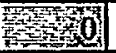 & 0 & 0 & 0 & 0 & 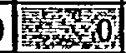 & 0 & 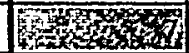 \\
\hline Parachironomus monochromus & $\mathbf{L}$ & 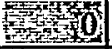 & 0 & 0 & 0 & 0 & 870 & 0 & Whis \\
\hline Pseudochironomus & $\mathrm{L}$ & 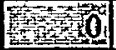 & 0 & 0 & 0 & 0 & 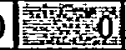 & 0 & 1 \\
\hline Polypedilum illinoense & $\mathbf{L}$ & 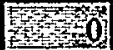 & 0 & 0 & 0 & 0 & 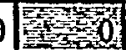 & 0 & \\
\hline
\end{tabular}

ORDER DIPTERA - (Tanytarsini)

Tanytarsus

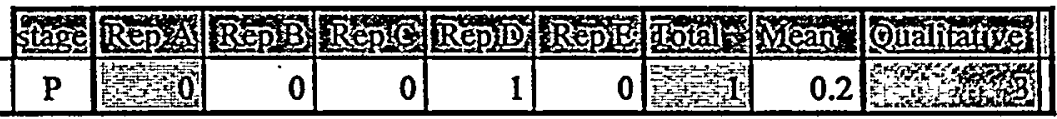

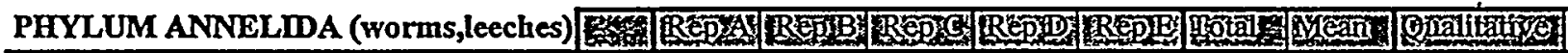
Lumbriculidae

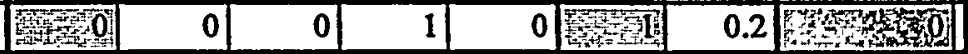

\begin{tabular}{|c|c|c|c|c|c|c|c|c|c|}
\hline PHYLUM MOLLUSCA (clams, snails) & 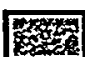 & Rep & $\mathrm{BPB}$ & इRp & Repio & RepI & atoin & 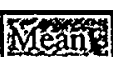 & 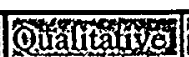 \\
\hline Ferrissia & snail & $\therefore 0$ & 1 & 0 & 0 & 0 & $=1$ & 0.2 & Tin \\
\hline Sphaerium & clam & $1^{14}=$ & 0 & 0 & 0 & 0 & Fo & 0 & 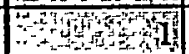 \\
\hline
\end{tabular}


Appendix Table B-3. Macroinvertebrate Data, by Replicate

Client: Westinghouse Savannah River Company

Stream: Four Mile Branch (Site 9)

County: Barnwell, SC

Collection Date: 5 Nov - 8 Dec 1997

Site / \# of Organisms

\begin{tabular}{|c|c|c|c|c|c|c|c|c|c|}
\hline ORDER EPHEMEROPTERA (mayllies) & 5 & 迎的 & Repin & Rep & Rep & Rep & Fista & tean & Qualitad \\
\hline Baetis frondalis & $\mathbf{N}$ & $\sqrt{50}$ & 0 & 0 & 0 & 0 & (3) & 0 & 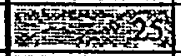 \\
\hline Baetis intercalaris & $\mathbf{N}$ & 两 & 1 & 0 & 7 & 2 & 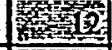 & 2.4 & 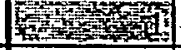 \\
\hline Paraleptophlebia & $\mathrm{N}$ & 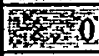 & 0 & 0. & $\underline{0}$ & $\underline{0}$ & S & $\underline{0}$ & 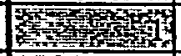 \\
\hline Stenonema modestum/smithae & $\mathbf{N}$ & 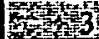 & 3 & 4 & 8 & 4 & 22 & 4.4 & 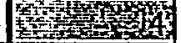 \\
\hline
\end{tabular}

\begin{tabular}{|c|c|c|c|c|c|c|c|c|c|}
\hline ORDER PLECOPTERA (sto & stage & 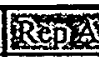 & p & Repis & 西 & Rep & toral & Ean & onlfative \\
\hline Paragnetina fumosa & $N$ & 5 & 0 & 0 & 0 & 1 & 67 & 0.2 & \\
\hline Taeniopteryx metequi & $\mathbf{N}$ & 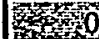 & 3 & 1 & 1 & & 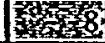 & 1.6 & Fons \\
\hline
\end{tabular}

\begin{tabular}{|c|c|c|c|c|c|c|c|c|c|}
\hline ORDER TRICHOPTERA (caddisflies) & stags & Rep & n & Reg & Sep & $\overline{\mathrm{B} \in \mathrm{p}}$ & gral: & Eean & Contratre \\
\hline Cheumatopsyche & $\mathrm{L}$ & 39 & 54 & 58 & 24 & 24 & 1996 & 39.8 & 15) \\
\hline Chimarra aterrima & $\mathbf{L}$ & 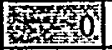 & 2 & 1 & 0 & 1 & 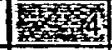 & 0.8 & 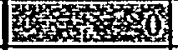 \\
\hline Hydropsyche betteni & $\bar{L}$ & 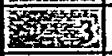 & 2 & 0 & 1 & $\underline{0}$ & 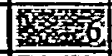 & 1.2 & 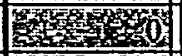 \\
\hline Lype diversa & L & 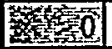 & 0 & 1 & 0 & 1 & 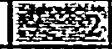 & 0.4 & 3. \\
\hline Triaenodes & $\mathrm{L}$ & gron & 0 & 0 & 0 & 1 & 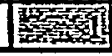 & 0.2 & 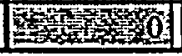 \\
\hline
\end{tabular}

\begin{tabular}{|c|c|c|c|c|c|c|c|c|c|}
\hline ORDER ODONATA (dragonflies) & 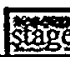 & 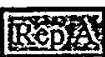 & Rep & Bep & Epin & Rep & (x) & Min & Quallation \\
\hline Argia sp & $\mathbf{N}$ & 20 & 0 & 0 & 0 & 0 & 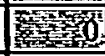 & 0 & 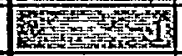 \\
\hline Calopteryx dimidiata & $\mathbf{N}$ & Y) & 0 & 0 & 0 & 0 & 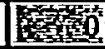 & 0 & 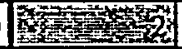 \\
\hline Enallagma sp. & $\mathbf{N}$ & 0 & 0 & 0 & 0 & 0 & 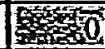 & 0 & 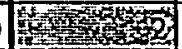 \\
\hline
\end{tabular}

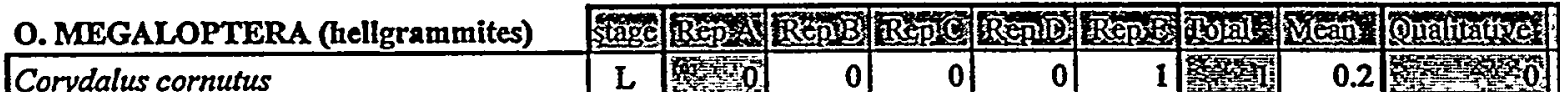

\begin{tabular}{|c|c|c|c|c|c|c|c|c|c|}
\hline ORDER COLEOPTERA (beetles) & 5 & Repul & 㯊 & REDC & Repan & Eep & 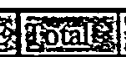 & eant & Quatitative \\
\hline Macronychus glabratus & $L, A$ & 3t? & 3 & 1 & I & & 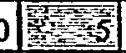 & 1 & \\
\hline Stenelmis crenata & $\mathrm{A}$ & 5no & 0 & 1 & 0 & 0 & 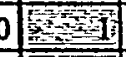 & 0.2 & 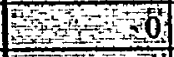 \\
\hline Stenelmis sp. & L & 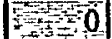 & 0 & 0 & $\mathbf{0}$ & 1 & 111 & 0.2 & 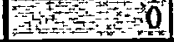 \\
\hline
\end{tabular}

\begin{tabular}{|c|c|c|c|c|c|c|c|c|c|}
\hline ORDER DIPTERA - other than midges & stage & REpity & Repin & Repes & Rep & 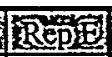 & gita & eange & Quiditarine \\
\hline Hemerodromia & $L$ & 80 & 1 & $\overline{0}$ & 0 & 0 & 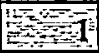 & 0.2 & Pton \\
\hline Simulium viltalum complex & $\mathrm{L}$ & $D_{1}$ & 0 & 0 & $\underline{0}$ & 0 & in & 0.2 & +0 \\
\hline Simulium nr. verecundum & L & $E 0$ & 0 & 0 & 1 & 2 & 3 & 0.6 & iq \\
\hline Simulium tuberosum complex & $\mathrm{L}$ & $8: 2$ & 0 & 1 & 0 & 14 & 17 & 3.4 & 0 \\
\hline
\end{tabular}


Appendix Table B-3. Macroinvertebrate Data, by Replicate

Client: Westinghouse Savannah River Company

Stream: Four Mile Branch (Site 9)

County: Barnwell, SC

Collection Date: 5 Nov - 8 Dec 1997

Site / \# of Organisms

ORDER DIPTERA - (Tanypodinae) Paramerina s.

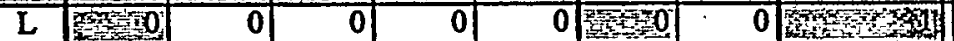

\begin{tabular}{|c|c|c|c|c|c|c|c|c|c|}
\hline ORDER DIPTERA - (Orthocladiinae) & stage & Repax & & Rep:S: & Rep & ERepges & pra国 & Eañ & Qunalifary \\
\hline Cricotopus bicinctus & $\mathbf{L}$ & menting & 2 & 0 & 0 & 2 & tivis & 1 & 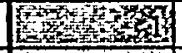 \\
\hline Parakiefferiella & $\mathbf{L}$ & S & 0 & 1 & 0 & 0 & 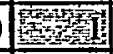 & 0.2 & 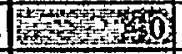 \\
\hline Parametriocnemus lundbecki & L, P & 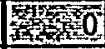 & 0 & $\mathbf{0}$ & 0 & 3 & 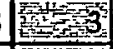 & 0.6 & 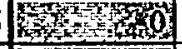 \\
\hline Rheocricotopus robacki & $\mathrm{L}$ & S & $\underline{0}$ & $\underline{0}$ & 1 & 0 & 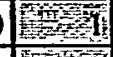 & 0.2 & 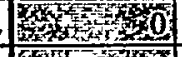 \\
\hline Thienemanniella xena gp. & $\mathbf{L}$ & W & 0 & 0 & 0 & 0 & 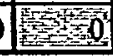 & $\underline{0}$ & 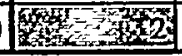 \\
\hline
\end{tabular}

ORDER DIPTERA - (Chironomini)

Dicrotendipes nr. neomodestus Phaenopsectra flavipes

Polypedilum aviceps

Polypedilum illinoense STEQ Rep

CLASS CRUSTACEA (crayfish, shrimp) Crangonyx obliquus-richmondensis A $\left.3 x^{\circ}\right]$

\begin{tabular}{|c|c|c|c|}
\hline 0 & 1 & 3 & 1 \\
\hline 0 & 0 & 0 & 0 \\
\hline 0 & 0 & 0 & 1 \\
\hline 2 & 0 & 0 & 0 \\
\hline
\end{tabular}

\begin{tabular}{|c|c|c|}
\hline 35 & 1 & 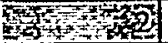 \\
\hline 4 & 0.2 & Buts \\
\hline 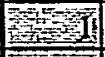 & 0.2 & 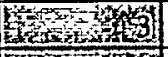 \\
\hline 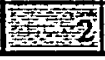 & 0.4 & 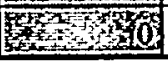 \\
\hline
\end{tabular}

ORDER LEPDOPTERA (moths)

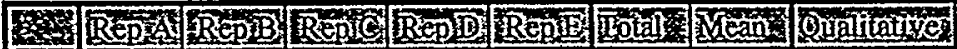
Parapoynx obscuralis L

PHYLUM MOLLUSCA (clams, snails) Corbicula fluminea

Physella heterostropha

\begin{tabular}{|c|c|c|c|c|c|c|c|c|}
\hline$\$ 8$ & Bepas & Rep & Repcis & REp & Rep & 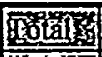 & Mantin & Qualitatose \\
\hline clam & 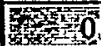 & 0 & 0 & 0 & 0 & 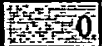 & 0 & 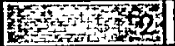 \\
\hline sn & 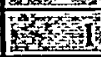 & 0 & 2 & 0 & 0 & 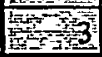 & 0.6 & 4 \\
\hline
\end{tabular}


Appendix Table B-3. Macroinvertebrate Data, by Replicate

Client: Westinghouse Savannah River Company

Stream: Pen Branch (Site 10)

County: Barnwell, SC

Collection Date: 5 Nov - 8 Dec 1997

Site / \# of Organisms

\begin{tabular}{|c|c|c|c|c|c|c|c|c|c|}
\hline ORDER EPHEMEROPTEI & tage & Reptix & 跑 & Repis & sepge & Repir & 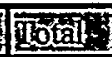 & Mean: & Qnolitare \\
\hline Leptophlebia & $\mathbf{N}$ & 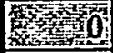 & 1 & 0 & 2 & 0 & 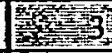 & 0.6 & 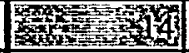 \\
\hline Itenacron interpunctatum & $\mathbf{N}$ & 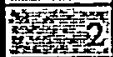 & 3 & 0 & 3 & 1 & $\sqrt{3}+9$ & 1.8 & ] \\
\hline tenonema modestum/smithae & $\mathrm{N}$ & 56 & 8 & 8 & 8 & 18 & 58 & 11.6 & 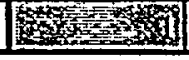 \\
\hline
\end{tabular}

ORDER PLECOPTERA (stoneflies)

\begin{tabular}{|c|c|c|c|c|c|c|c|c|c|}
\hline Allocapnia & $\mathrm{N}$ & 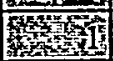 & 3 & 5 & 3 & 2 & 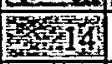 & 2.8 & 1030 \\
\hline Clioperla clio & $\mathbf{N}$ & 19x & 0 & 0 & 0 & 0 & 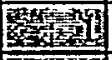 & 0.2 & $-x_{0}$ \\
\hline Leuctra & $N$ & 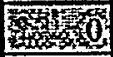 & 0 & 0 & 0 & 0 & 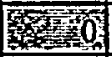 & 0 & 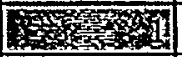 \\
\hline Perilinella ephyre & $\mathrm{N}$ & 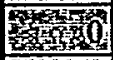 & 0 & 0 & 1 & 0 & 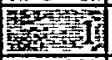 & 0.2 & 3yin \\
\hline Taeniopteryx metequi & $\mathrm{N}$ & 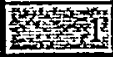 & 0 & 0 & 0 & 0 & 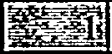 & 0.2 & (x) \\
\hline
\end{tabular}

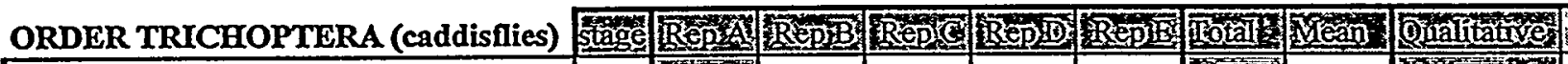

\begin{tabular}{|c|c|c|c|c|c|c|c|c|c|}
\hline Anisocentropus pyraloides & $\mathbf{L}$ & 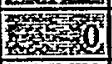 & 0 & 0 & of & $\underline{0}$ & 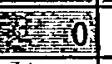 & 0 & 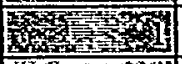 \\
\hline Cheumatopsyche & $L$ & 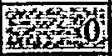 & 0 & 0 & 0 & $\underline{0}$ & 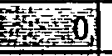 & 0 & 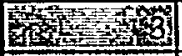 \\
\hline Hydropsyche betteni & L & 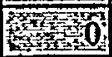 & & 0 & 0 & $\underline{0}$ & 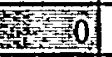 & 0 & ming \\
\hline Pycnopsyche sp. & $\mathrm{L}$ & 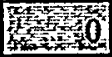 & I & 0 & 0 & $\underline{0}$ & 留 & & \\
\hline
\end{tabular}

ORDER ODONATA (dragonflies)

\begin{tabular}{|c|c|c|c|c|c|c|c|c|c|}
\hline Argia tibialis & $\mathrm{N}$ & 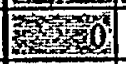 & 1 & 0 & 0 & 1 & 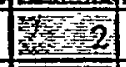 & 0.4 & $7 x^{2}$ \\
\hline Calopteryx dimidiata & $\mathrm{N}$ & 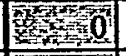 & 0 & 0 & 0 & 0 & 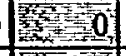 & 0 & 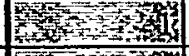 \\
\hline Enallagma nr. divagans & $\mathrm{N}$ & 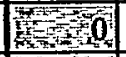 & 0 & 0 & 0 & 0 & Fin & 0 & Dis \\
\hline Gomphus lividus & $\mathrm{N}$ & 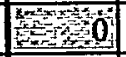 & 0 & 0 & 0 & 0 & S & 0 & 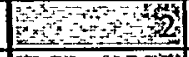 \\
\hline Libellula & $\mathbf{N}$ & ments & $\underline{0}$ & 0 & 0 & 0 & 00 & 0 & \\
\hline Lanthus vernalis & $\mathbf{N}$ & rat & 0 & 0 & 0 & 0 & 20 & 0 & \\
\hline
\end{tabular}


Appendix Table B-3. Macroinvertebrate Data, by Replicate

Client: Westinghouse Savannah River Company

Stream: Pen Branch (Site 10)

County: Barnwell, SC

Collection Date: 5 Nov - 8 Dec 1997

\begin{tabular}{|c|c|c|c|c|c|c|c|c|c|}
\hline ORDER COLEOPTERA (beetles) & 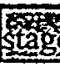 & Lep & Rep B & Repic & REPD & Kepis & 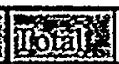 & Weai & Quarititife \\
\hline Hydroporus sp. & $\mathrm{A}$ & 150 & 0 & 0 & 0 & 0 & 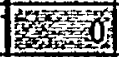 & 0 & Strins \\
\hline Hydroporus vittatipennis & A & 18 & 0 & 0 & 0 . & $\overline{0}$ & 15n & $\overline{0}$ & 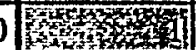 \\
\hline Optioservus & L & 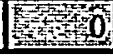 & 0 & 0 & 0 & 0 & 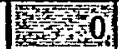 & $\overline{0}$ & 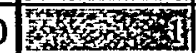 \\
\hline
\end{tabular}

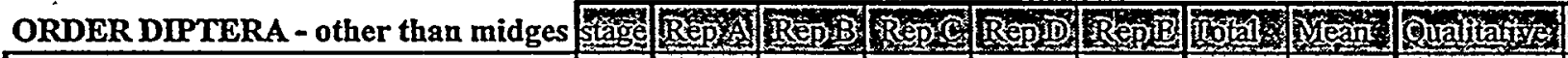

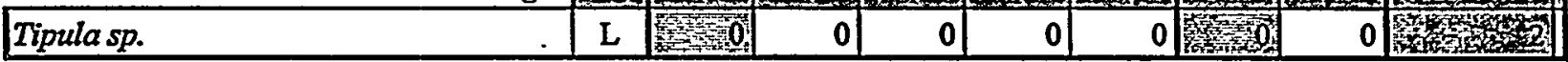

\begin{tabular}{|c|c|c|c|c|c|c|c|c|c|}
\hline ORDER DIPTERA - (Tanypodinae) & 5 & Rep & Repis & Repo & RepD & Sepin & Rotat & Mean & Qunitarixe \\
\hline Clinotanypus pinguis & $\mathrm{L}$ & (1) & 0 & 0 & 0 & $\mathbf{0}$ & 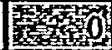 & 0 & 18 \\
\hline Natarsia & $\bar{L}$ & Ty & 0 & 0 & 0 & 0 & 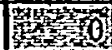 & 0 & 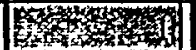 \\
\hline Zavrelintyia & $\mathrm{L}$ & 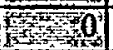 & 0 & 0 & 0 & $\overline{0}$ & ras & 0 & 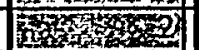 \\
\hline Procladius & $\mathrm{L}$ & rat & 0 & 0 & 0 & 0 & 17not & 0 & 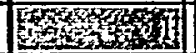 \\
\hline
\end{tabular}

\begin{tabular}{|c|c|c|c|c|c|c|c|c|}
\hline ORDER DIPTERA - (Orthocladiinae) & stage & Rep & 寍ep & geptC & Rep & ERpig & Totalig & Mean Qualitatu \\
\hline Heterotrissocladius marcidus gp. & $\mathbf{L}$ & 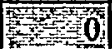 & 0 & $\overrightarrow{0}$ & 이 & 0 & $\sqrt{5}$ & 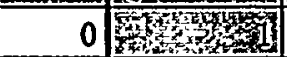 \\
\hline Parametriocnemus lundbecki & $\mathrm{L}, \mathrm{P}$ & 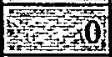 & 0 & 0 & 0 & 0 & ris & 0 \\
\hline Unniella multivirga & L & 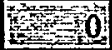 & 0 & 0 & 0 & 0 & 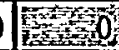 & 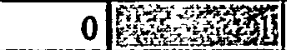 \\
\hline
\end{tabular}

\begin{tabular}{|c|c|c|c|c|c|c|c|c|c|}
\hline ORDER DIPTERA - (Chironomini) & the & Rep & Rep & Repge & RepiD & SPE & 10toty & Seant & Quilifatre \\
\hline Microtendipes nr. pedellus & $\mathrm{L}$ & 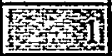 & 7 & 1 & 3 & 10 & 63 & 4.4 & 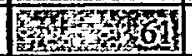 \\
\hline Phaenopsectra flavipes & $\bar{L}$ & 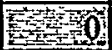 & 0 & $\overline{0}$ & 0 & $\overline{0}$ & 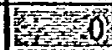 & 0 & 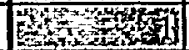 \\
\hline Polypedilum aviceps & $\mathrm{L}$ & St & 0 & 0 & 0 & 0 & 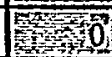 & 0 & $\sqrt{2}$ \\
\hline
\end{tabular}


Appendix Table B-3. Macroinvertebrate Data, by Replicate

Client: Westinghouse Savannah River Company

Stream: Pen Branch (Site 10)

County: Barnwell, SC

Collection Date: 5 Nov - 8 Dec 1997

Site / \# of Organisms

\begin{tabular}{|c|c|c|c|c|c|c|c|c|c|}
\hline ORDER DIPTERA - (Tanytarsini) & $5 t$ & RepA & 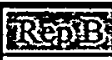 & Repig & Eep & 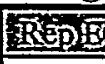 & gotaly & 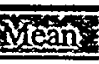 & 0ualitate \\
\hline Rheotanytarsus distinctissimus gp. & $\mathbf{L}$ & 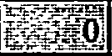 & 1 & 0 & $\underline{0}$ & $\underline{0}$ & 8 & 0.2 & st \\
\hline Tanytarsus & $\mathbf{P}$ & 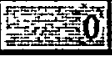 & 0 & 0 & 0 & 0 & 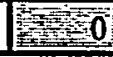 & $\mathbf{0}$ & 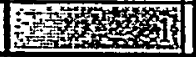 \\
\hline
\end{tabular}

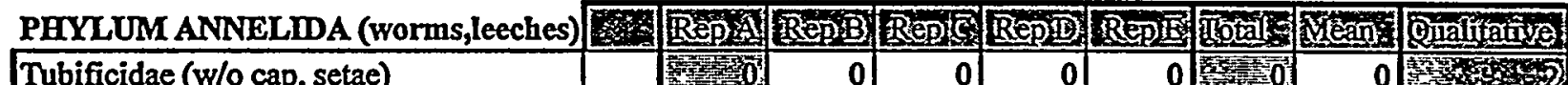

\begin{tabular}{|c|c|c|c|}
\hline Tubificidae (w/o cap. setae) & 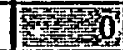 & $\overline{0}$ & \\
\hline
\end{tabular}

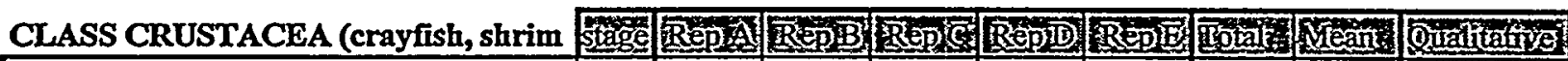

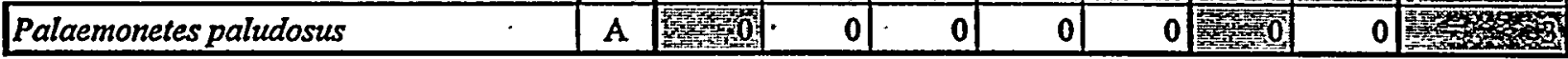

\begin{tabular}{|c|c|c|c|c|c|c|c|c|}
\hline PHYLUM MOLLUSCA & $\mathrm{E}$ & Repal & Rep & Repic & Repin & Repie & Mean & Qualitats \\
\hline Campeloma decisum & snail & T) & 0 & 0 & 0 & 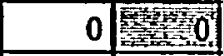 & 0 & W \\
\hline Sphaerium & clam & 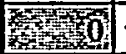 & 0 & 0 & 0 & 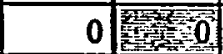 & 0 & 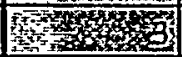 \\
\hline
\end{tabular}




\section{Appendix Table B-3. Macroinvertebrate Data, by Replicate}

\section{Client: Westinghouse Savannah River Company}

Stream: Pen Branch (Site 11)

County: Baruwell, SC

Collection Date: 5 Nov - 8 Dec 1997

Site / \# of Organisms

\begin{tabular}{|c|c|c|c|c|c|c|c|c|c|}
\hline ORDER EPHEMEROPTERA (mayflies) & signg & Rep & (BB & 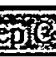 & Reping & 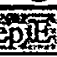 & Sotallo & Bging & Qualfative \\
\hline Baetis intercalaris & $\mathbf{N}$ & 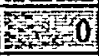 & 0 & 0 & 1 & 0 & ving & 0.2 & 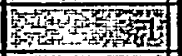 \\
\hline Ephemerella (immature / damaged) & $\mathrm{N}$ & 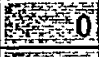 & 0 & $\underline{0}$ & 6 & $\mathbf{0}$ & 46 & 1.2 & 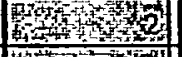 \\
\hline Paraleptophlebia & $\mathbf{N}$ & 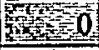 & 0 & 0 & 0 & 0 & 0 & 0 & 10 \\
\hline Stenonema modestum/smithae & $\mathrm{N}$ & Intil & 14 & 18 & 16 & 3 & 62 & 12.4 & 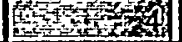 \\
\hline
\end{tabular}

ORDER PLECOPTERA (stoneflies)

\begin{tabular}{|c|c|c|c|c|c|c|c|c|c|c|}
\hline Allocapnia & $\mathrm{N}$ & 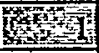 & 3 & 0 & & & 2 & tis & 1.8 & 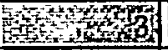 \\
\hline Perlesta placida & $\mathrm{N}$ & X & 2 & 1 & & 1 & 1 & 7 & 1 & S1 \\
\hline Taeniopteryx metequi & $\mathrm{N}$ & 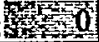 & 1 & 4 & & 9| & & 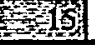 & 3 & F. \\
\hline
\end{tabular}

ORDER TRICHOPTERA (caddisflies)

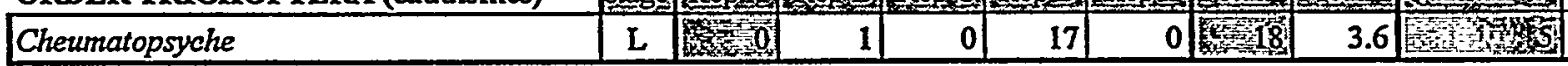

ORDER ODONATA (dragonflies)

\begin{tabular}{|c|c|c|c|c|c|c|c|c|c|}
\hline Argia sp & $\mathbf{N}$ & $y_{2}$ & $\mathbf{0}$ & 0 & 0 & 0 & 30 & 0 & 40 \\
\hline Boyeria vinosa & $\mathrm{N}$ & 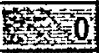 & 0 & 0 & 0 & 0 & 300 & $\mathbf{0}$ & सx \\
\hline Calopteryx dimidiafa & $\mathbf{N}$ & 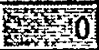 & 0 & 0 & 0 & 0 & 50 & 0 & 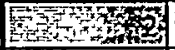 \\
\hline Gomphus lividus & $N$ & 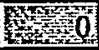 & 0 & 0 & 0 & $\underline{0}$ & 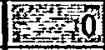 & 0 & 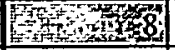 \\
\hline Macromia georgina / illinoiensis & $\mathbf{N}$ & 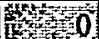 & $\mathbf{0}$ & 0 & 0 & 0 & Fit 0 & 0 & 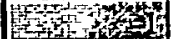 \\
\hline
\end{tabular}

ORDER HETEROPTERA (true bugs)

Mesovelia

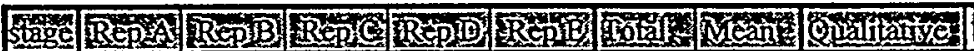

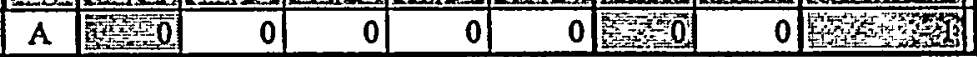




\title{
Appendix Table B-3. Macroinvertebrate Data, by Replicate
}

\author{
Client: Westinghouse Savannah River Company \\ Stream: Pen Branch (Site 11) \\ County: Barnwell, SC \\ Collection Date: 5 Nov - 8 Dec 1997
}

Site / \# of Organisms

\begin{tabular}{|c|c|c|c|c|c|c|c|c|}
\hline O. MEGALOPTERA (he & $\sqrt{59 g e}$ & Eeping & Bep & Bepid & Rep & 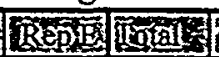 & Yen: & Qualtotios \\
\hline Sialis & $\mathrm{L}$ & 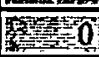 & $\overline{0}$ & 0 & 0 & 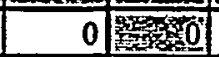 & 0 & STh \\
\hline Nigronia serricornis & $\mathbf{L}$ & 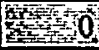 & 0 & 0 & 0 & 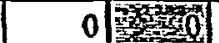 & 0 & 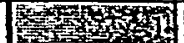 \\
\hline
\end{tabular}

\begin{tabular}{|c|c|c|c|c|c|c|c|c|c|}
\hline ORDER COLEOPTERA (beetles) & 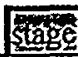 & Repsis & & setg & Reping & $\mathrm{R} x \mathrm{pip}$ & 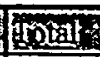 & Mean & Qualinestes \\
\hline Ancyronyx variegatus & $\mathrm{L}, \mathrm{A}$ & Not & 0 & 1 & 1 & $\overline{0}$ & 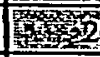 & 0.4 & 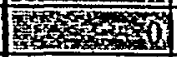 \\
\hline Dubiraphia sp. & $\mathrm{L}, \mathrm{A}$ & N & 0 & 0 & 0 & 0 & 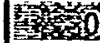 & 0 & (2) \\
\hline Ectopria nervosa & $\mathbf{L}$ & 10 & 0 & 0 & 1 & 0 & 15 & 0.2 & S6 \\
\hline Helichus lithophilus & A & 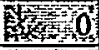 & 0 & 0 & $\underline{0}$ & 0 & 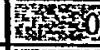 & $\underline{0}$ & 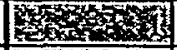 \\
\hline Macronychus glabratus & $\mathrm{L}, \mathrm{A}$ & 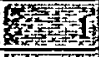 & 1 & $\underline{0}$ & 1 & $\underline{0}$ & 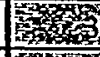 & 0.6 & $5 \mathrm{~g}$ \\
\hline Stenelmis sp. & L & 6 & 0 & 0 & 0 & 0 & 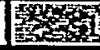 & 0.2 & 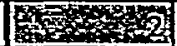 \\
\hline
\end{tabular}

\begin{tabular}{|c|c|c|c|c|c|c|c|c|c|}
\hline ORDER DIPTERA - other than midges & stas & 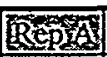 & RPDB: & repecis & (Tepin & Sepis & 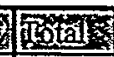 & Mesing & Qualitirize \\
\hline Pilaria & $\mathrm{L}$ & 40 & 0 & 0 & $\underline{0}$ & 0 & 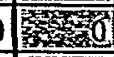 & 0 & Sin \\
\hline Simulium tuberosum complex & L & $x=0$ & 0 & $\mathbf{0}$ & $\mathbf{0}$ & 0 & 0 & 0 & 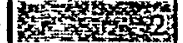 \\
\hline Tipula sp. & $\mathrm{L}$ & 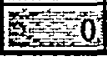 & 0 & $\underline{0}$ & .0 & 0 & 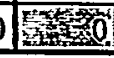 & 0 & 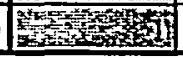 \\
\hline
\end{tabular}

\begin{tabular}{|c|c|c|c|c|c|c|c|c|}
\hline ORDER DIPTERA - (Tanypodinae) & 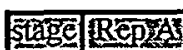 & REpiB: & Regia & RpDig: & FREIF & 然自国 & MEan: & Qualitarixe \\
\hline Conchapelopia & $\mathrm{L}$ & 0 & 0 & 1 & & 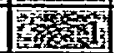 & 0.2 & Ring \\
\hline Zavrelimyia & 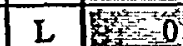 & 0 & 0 & 0 & 0 & 3. & & 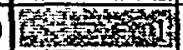 \\
\hline
\end{tabular}

\begin{tabular}{|c|c|c|c|c|c|c|c|c|c|}
\hline ORDER DIPTERA - (Orthocladiinae) & 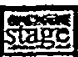 & Bep & Bep & Repa & Repte & $\sqrt{\mathrm{Rep} \mathrm{S}^{2}}$ & $3 \overline{90619}$ & Mean & Onalita \\
\hline Corynoneura & L & 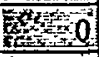 & 0 & 0 & $\underline{0}$ & 0 & 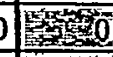 & 0 & 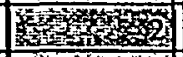 \\
\hline Nanocladius & $\mathbf{L}$ & 0 & 0 & 0] & & 0 & 0 & 0 & 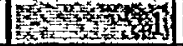 \\
\hline Orthocladius nr. annectens & $\mathrm{L}$ & $x=0$ & 1 & 0 & & 0 & 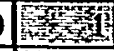 & 0.2 & \\
\hline Orthocladius (Symposiocladius) lignicola & $\mathrm{L}$ & No & 1 & 0 & & 0 & 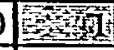 & 0.2 & 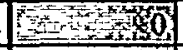 \\
\hline Orthocladius obumbratus & $\mathcal{L}$ & 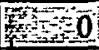 & 2 & 0 & & $\overline{0}$ & 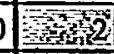 & 0.4 & $8 x$ \\
\hline Parakiefferiella & L & Sto & 0 & 0 & & 0 & $\Rightarrow$ & & 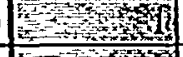 \\
\hline Parametriocnemus lundbecki & $\mathrm{L}, \mathrm{P}$ & 80 & 3 & 0 & & 1 & 16 & 1.2 & 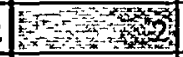 \\
\hline Rheocricotopus robacki & $\mathrm{L}$ & mo & 1 & 1 & & 1 & trist & & E \\
\hline Thienemanniella fusca gp. & $\mathrm{L}$ & $F$ & 0 & 이 & & 0 & 00 & 0 & Nent \\
\hline
\end{tabular}

ORDER DIPTERA - (Chironomini)

\begin{tabular}{|c|c|c|c|c|c|c|c|c|c|}
\hline ORDER DIPTERA - (Chironomini) & stag! & Beps] & RepB & PL & (9) & & & $\operatorname{can}$ & \\
\hline Pagastiella & $\mathrm{L}$ & 0 & 0 & 0 & 0 & 0 & $=0$ & 0 & $10 \cdots+1$ \\
\hline Polypedilum aviceps & $\mathbf{L}$ & $\begin{array}{lll}0 & 0 \\
0 & 0 & 0\end{array}$ & 0) & 0 & 3 & 0 & 3 & 0.6 & $\because \quad 1$ \\
\hline
\end{tabular}


Appendix Table B-3. Macroinvertebrate Data, by Replicate

Client: Westinghouse Savannah River Company

Stream: Pen Branch (Site 11)

County: Barnwell, SC

Collection Date: 5 Nov - 8 Dec 1997

Site / \# of Organisms

ORDER DIPTERA - (Tanytarsini)

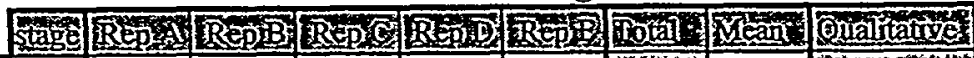

Rheotanytarsus distinctissimus gp.

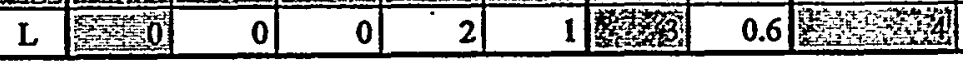

CLASS CRUSTACEA (craytish, shrimp)

Caecidotea

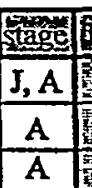

Rep

Cambarinae

A 1 in

B. B K

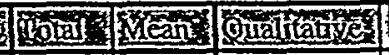

Palaemonetes paludosus

\begin{tabular}{|c|c|c|c|c|c|c|c|}
\hline 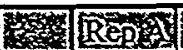 & Rein & Reptc & Rep & Rej & 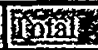 & Yien & $1 \mathrm{e}$ \\
\hline$g 0$ & 0 & 0 & 1 & 0 & (5x) & 0.2 & 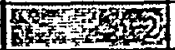 \\
\hline 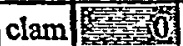 & 0 & 0 & 0 & 0 & 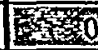 & 0 & 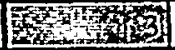 \\
\hline
\end{tabular}

PHYLUM MOLLUSCA (clams, snails)

Corbicula fluminea

Sphaerium

clam 0

\begin{tabular}{|c|c|c|c|c|c|c|}
\hline 0 & 1 & 0 & 0 & 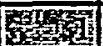 & 0.2 & Fir \\
\hline 0 & 0 & 0 & 0 & 6 & 0 & 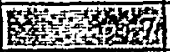 \\
\hline$\overline{0}$ & 0 & $\overline{0}$ & $\overline{0}$ & 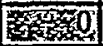 & 0 & 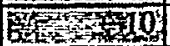 \\
\hline
\end{tabular}


Appendix Table B-3. Macroinvertebrate Data, by Replicate

Client: Westinghouse Savannah River Company

Stream: Indian Grave Branch (Site 12)

County: Barnwell, SC

Collection Date: 5 Nov - 8 Dec 1997

Site / \# of Organisms

\begin{tabular}{|c|c|c|c|c|c|c|c|c|c|}
\hline ORDER EPHEMEROPTERA (mayflie & stage & & Bepis & ice & Rep D & EDIE & & Yean & |20 \\
\hline allibaetis & $\mathrm{N}$ & 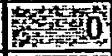 & 의 & 0 & 의 & 0 & 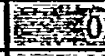 & 0 & 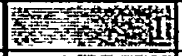 \\
\hline araleptophlebia & $\mathrm{N}$ & 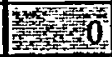 & 이 & 1 & 0 & 0 & atid & 0.2 & 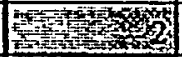 \\
\hline enonema modestumb & $\mathbf{N}$ & Xis & 이 & 11 & 4 & 7 & 涪 & 51 & 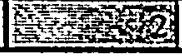 \\
\hline
\end{tabular}

\begin{tabular}{|c|c|c|c|c|c|c|c|c|c|}
\hline ORDER TRICHOPTERA (caddisflies) & stape & Bepay & Bep B & Bep & Repin & Rep & 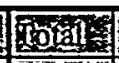 & mean & Qualichis \\
\hline Cernotina spicata & $L$ & Sin & 0 & 0 & 1 & 0 & 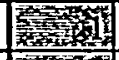 & 0.2 & 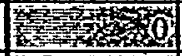 \\
\hline Cheumatopsyche & $\mathrm{L}$ & 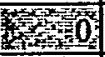 & $\underline{0}$ & 0 & 0 & 1 & 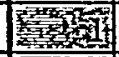 & 0.2 & 等 \\
\hline Chimarra aterrima & $\mathrm{L}$ & 450 & 0 & 이 & 아 & o & 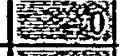 & $\underline{0}$ & 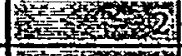 \\
\hline Lype diversa & $L$ & 1380 & 0 & 0 & 0 & 0 & 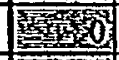 & $\underline{0}$ & \\
\hline Oxyethira & $\mathrm{L}$ & 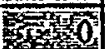 & $\overline{0}$ & 0 & 0 & & 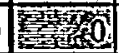 & & 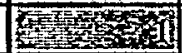 \\
\hline
\end{tabular}

ORDER ODONATA (dragonflies)

\begin{tabular}{|c|c|c|c|c|c|c|c|c|c|}
\hline Boyeria vinosa & $\mathbf{N}$ & 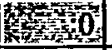 & 0 & 0 & 0 & $\underline{0}$ & 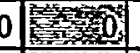 & 0 & Ant \\
\hline Epitheca (Epicordulia) & $\mathbf{N}$ & 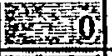 & 0 & 1 & 0 & & 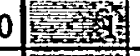 & 0.2 & Hon \\
\hline Erythrodiplax connata & $N$ & +80 & $\underline{0}$ & 0 & 1 & & 0| & 0.2 & 20 \\
\hline Libellula & $\mathbf{N}$ & 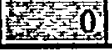 & $\underline{0}$ & 0 & 0 & 0 & $0 \mid \begin{array}{ll}0 \\
0\end{array}$ & 0 & 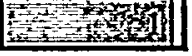 \\
\hline
\end{tabular}

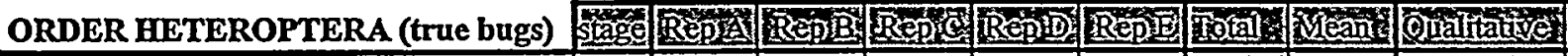

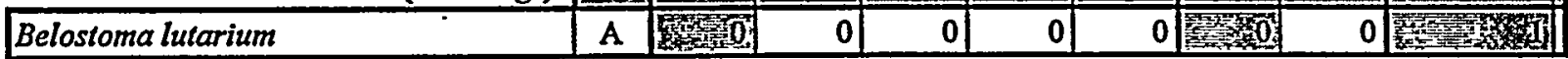

\begin{tabular}{|c|c|c|c|c|c|c|c|c|c|}
\hline ORDER COLEOPTERA & tage & Sep & 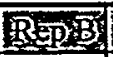 & Rep:圂 & 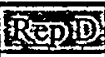 & Bep & Sotal & Wean & Oualtatide \\
\hline Hydroporus sp. & A & 17x & 의 & 1 & $\underline{0}$ & $\underline{0}$ & 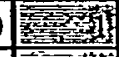 & 0.2 & 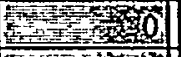 \\
\hline Stenelmis s & L & 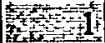 & 1 & 0 & 0 & 0 & 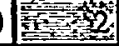 & 0.4 & 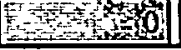 \\
\hline
\end{tabular}

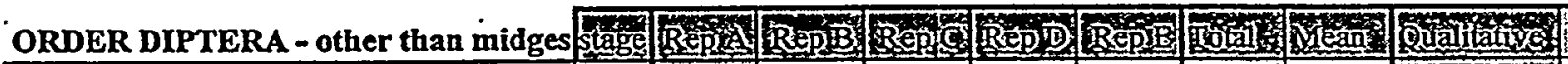

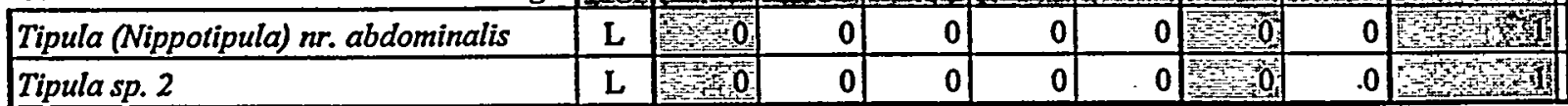


Appendix Table B-3. Macroinvertebrate Data, by Replicate

Client: Westinghouse Savannah River Company

Stream: Indian Grave Branch (Site 12)

County: Barnwell, SC

Collection Date: 5 Nov - 8 Dec 1997

Site / \# of Organisms

\begin{tabular}{|c|c|c|c|c|c|c|c|c|c|}
\hline ORDER DIPTEI & 5 & Repar & Rep & Repcic & Repi & Rep & Fotal & lean & Qinalitave \\
\hline Ablabesmyia mallochi & $\mathrm{L}$ & 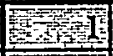 & 2 & 2 & 0 & 0 & 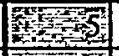 & 1 & 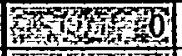 \\
\hline Conchapelopia & L & 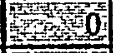 & 0) & 0 & 0 & 1 & Drits & 0.2 & 150 \\
\hline avrelimyia & $\bar{L}$ & tin & 0 & $\mathbf{0}$ & 1 & 0 & S6 & 0.2 & 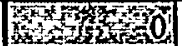 \\
\hline
\end{tabular}

\begin{tabular}{|c|c|c|c|c|c|c|c|c|c|}
\hline ORDER DIPTERA - (Orthocladiinae) & stage & Rep & Sep & Reps & RpD & Rep & 10 & (Ean & Tualtative \\
\hline Corynoneura & $\mathbf{L}$ & 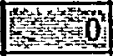 & 0 & 2 & 0 & 0 & 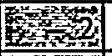 & 0.4 & 两 \\
\hline (Diamesinae)-Potthastia longimana & $\bar{L}$ & $0_{0}^{2}$ & 0 & 0 & 0 & 1 & Fis & 0.2 & 6 \\
\hline Parakiefferiella & $\mathbf{L}$ & S & 0 & 2 & 0 & 0 & 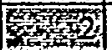 & 0.4 & 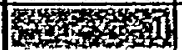 \\
\hline Parametriocnemus lundbecki & $\mathrm{L}, \mathrm{P}$ & 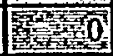 & 0 & 2 & o & 0 & 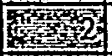 & 0.4 & 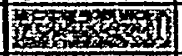 \\
\hline Thienemanniella xena gp. & $\mathrm{L}$ & 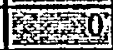 & 0 & 0 & 0 & 0 & 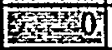 & & 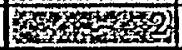 \\
\hline
\end{tabular}

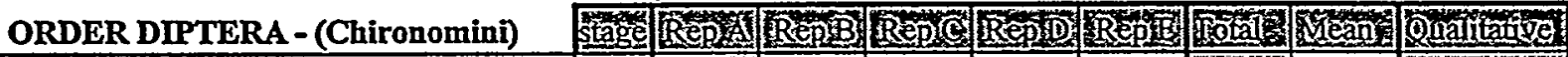

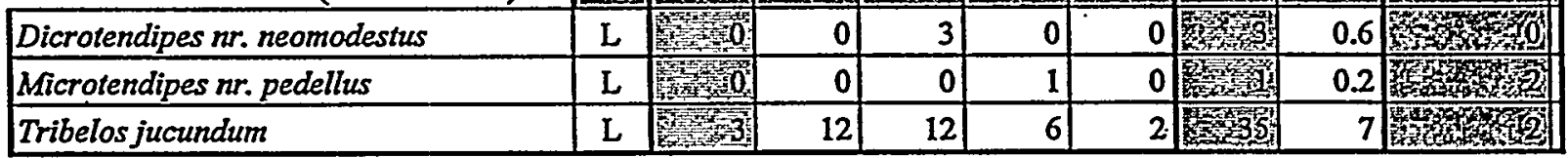

\begin{tabular}{|c|c|c|c|c|c|c|c|c|}
\hline ORDER DIPTERA - ( & titags & Repan & Repi & Bepac & Rep & 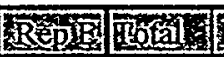 & r & \\
\hline Qheotc & $\mathrm{L}$ & 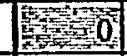 & 0 & 1 & 0 & 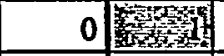 & 0.2 & 278 \\
\hline anytarsus & $\mathbf{P}$ & 3010 & 0 & 01 & 1 & 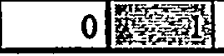 & 0.2 & 2 \\
\hline
\end{tabular}

\begin{tabular}{|c|c|c|c|c|c|c|c|}
\hline PHYLUM ANNELIDA (WO) & X: & $\mathrm{RepB}$ & REP & Repio & 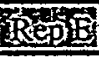 & 10tatia & Y \\
\hline Styl & 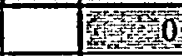 & 0 & 0 & 1 & 0 & 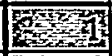 & 0.2 \\
\hline (w/o cap. setae) & 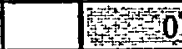 & 0 & 0 & 0 & & 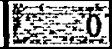 & \\
\hline
\end{tabular}

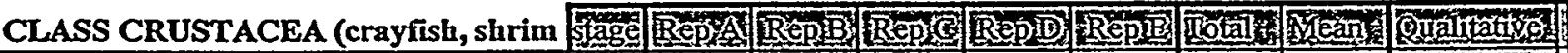

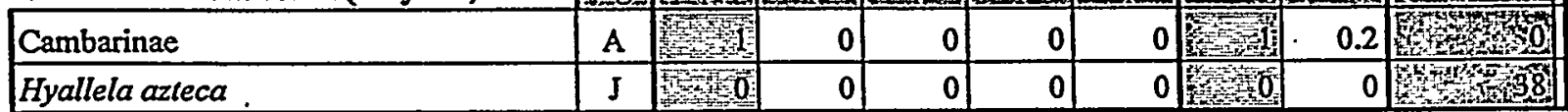

\begin{tabular}{|c|c|c|c|c|c|c|c|c|c|}
\hline PHYYUUM MOLLUSCA (clams, snails) & 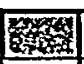 & Rep & Fep & 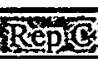 & Repi追 & Rep & Fotalle & Mean & Qualiatiy \\
\hline Corbicula fluminea & clam & $\therefore \quad 0$ & 0 & 0 & 0 & $\underline{0}$ & 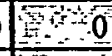 & 0 & \\
\hline Helisoma anceps & snail & 0 & 0 & $\underline{0}$ & 0 & $\underline{0}$ & 0 & 0 & 2 \\
\hline Sphaerium & clam & 0 & 0 & 0 & 0 & $\mathbf{0}$ & 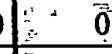 & 0 & \\
\hline Physella heterostropha & snail & 0 & 0 & I & 0 & 0 & 1 & 0.2 & \\
\hline
\end{tabular}


Appendix Table B-3. Macroinvertebrate Data, by Replicate

Client: Westinghouse Savannah River Company

Stream: Pen Branch (Site 13)

County: Barnwell, SC

Collection Date: 5 Nov - 8 Dec 1997

Site / \# of Organisms

\begin{tabular}{|c|c|c|c|c|c|c|c|c|c|}
\hline ORDER EPHEMEROPTERA (mayflies) & siget & Bes & Rep & Eep & [iepiD & mept & 90in & VEant & Quallation \\
\hline Baetis sp. & $\mathrm{N}$ & 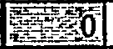 & 0 & 0 & 1 & $\underline{\mathbf{0}}$ & 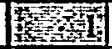 & 0.2 & 3xis \\
\hline Baetts frondalis & $\mathbf{N}$ & 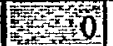 & 0 & 0 & $\mathbf{0}$ & 0 & 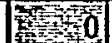 & o & \\
\hline Baetis intercalaris & $\mathbf{N}$ & 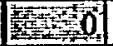 & 0 & $\mathbf{0}$ & $\mathbf{0}$ & $\mathbf{0}$ & 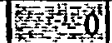 & 0 & 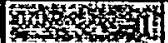 \\
\hline Neoephemera youngi & $\mathbf{N}$ & 78] & 0 & 0 & 0 & $\mathbf{0}$ & $\mid \begin{array}{ll}3 \\
3 x=0\end{array}$ & 0 & 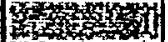 \\
\hline Stenonema modestum/smithae & $\mathbf{N}$ & D & 1 & 0 & 5 & 1 & vis: & 1.4 & 焉 \\
\hline
\end{tabular}

\begin{tabular}{|c|c|c|c|c|c|c|c|c|c|}
\hline ORDER TRICHOPTERA (caddisflies) & 5 stage & Rep & 5 & $\bar{C}$ & (1) & 29 & non & Mean & onalitaxive \\
\hline Cheumatopsyche & L & 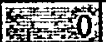 & 0 & 0 & 3 & 0 & Went & 0.6 & 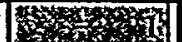 \\
\hline Hydrospyche sp. 2 & $\mathrm{~L}$ & 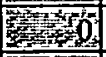 & 의 & $\underline{0}$ & $\underline{0}$ & $\underline{0}$ & Din & $\mathbf{0}$ & 58 \\
\hline Pycnopsyche & L & 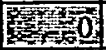 & 0 & $\underline{0}$ & $\underline{0}$ & 0 & 5is & 0 & 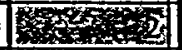 \\
\hline Triaenodes & L & xyot & 0 & $\overline{0}$ & $\mathbf{0}$ & 0 & 30 & 0 & S1 \\
\hline
\end{tabular}

\begin{tabular}{|c|c|c|c|c|c|c|c|c|c|}
\hline ORDER ODONATA (dragonflies) & Stats & Repg & $5 \mathrm{pB}$ & 5 & (1) & & (6) & Ean & Quallature \\
\hline Argia sp & $\mathrm{N}$ & 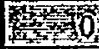 & 0 & 0 & $\underline{0}$ & $\mathbf{0}$ & 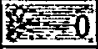 & $\mathbf{0}$ & 琵任 \\
\hline Calopteryx dimidiata & $\bar{N}$ & Fition & 0 & 0 & 0 & $\mathbf{0}$ & 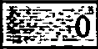 & $\mathbf{0}$ & 2 \\
\hline Enallagma sp. & $\mathrm{N}$ & 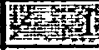 & 2 & $\mathbf{0}$ & 0 & 0 & 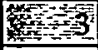 & 0.6 & 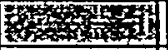 \\
\hline Macromia georgina / illinoiensis & $\mathbf{N}$ & Exin & $\mathbf{0}$ & 0 & 0 & & Tis & $\mathbf{0}$ & 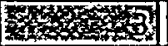 \\
\hline
\end{tabular}

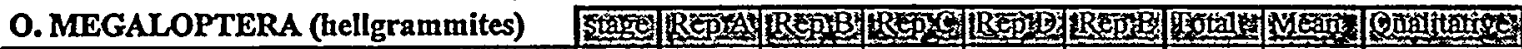

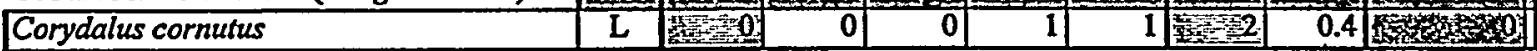

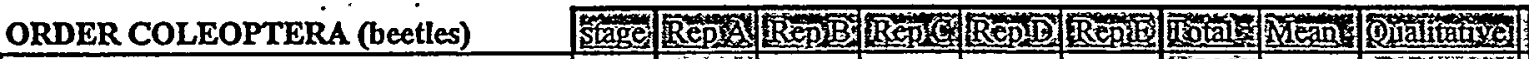

\begin{tabular}{|c|}
\hline Iacromychus glabratus \\
\hline
\end{tabular}

\begin{tabular}{|c|c|c|c|c|c|c|c|c|c|}
\hline ORDER DLPTERA - (Tanypodinae) & 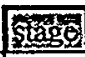 & Pap & ges: & Reps & Repin & Repis & 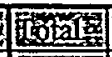 & Mean & oualitaty \\
\hline Ablabesmyia janta gp. & $\mathrm{L}$ & 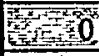 & o & 1 & $\underline{0}$ & $\underline{0}$ & intin & 0.2 & 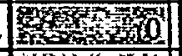 \\
\hline Clinotanypus pinguis & L & Po & 0 & 0 & $\overline{0}$ & 0 & 9010 & 0 & tyon \\
\hline Zavrelimyia & $\mathbf{L}$ & te & 0 & 0 & $\mathbf{0}$ & 1 & bit & 0.2 & 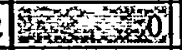 \\
\hline Procladius & $\mathbf{L}$ & $\mathrm{F}^{2}$ & 0 & 0 & 0 & $\mathbf{0}$ & $x=0$ & & 6ring \\
\hline
\end{tabular}




\section{Appendix Table B-3. Macroinvertebrate Data, by Replicate}

Client: Westinghouse Savannah River Company

Stream: Pen Branch (Site 13)

County: Barnwell, SC

Collection Date: 5 Nov - 8 Dec 1997

Site / \# of Organisms

\begin{tabular}{|c|c|c|c|c|c|c|c|c|c|}
\hline ORDER DIPTERA - (Orthocladiinae) & Stage & Sep & Rep & Ret? & Repla & Bम & 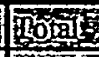 & icting & Oona \\
\hline Corynoneura & $\mathbf{L}$ & \pm 0 & 1 & ( & 0 & 0 & 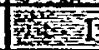 & 0.2 & 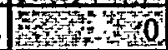 \\
\hline Cricotopus bici & L & 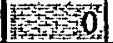 & 0 & ( & 0 & 0 & 13) & $\mathbf{0}$ & 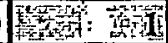 \\
\hline Hydrobaenus & $\mathbf{L}$ & E & 0 & & 0 & 0 & 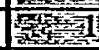 & 0.2 & $5+40$ \\
\hline Orthocladius sp. & L & 8 & 0 & ( & 0 & 0 & 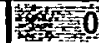 & 0 & $x \rightarrow y=4$ \\
\hline Orthocladius obumbratus & $\mathbf{L}$ & 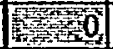 & 0 & & 0 & $\overline{0}$ & 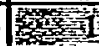 & 0.2 & 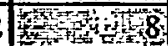 \\
\hline Parakiefferiella & $\mathbf{L}$ & 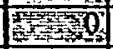 & c & & 2 & $\overline{0}$ & $\sqrt{3 x^{3}}$ & $\overline{1.6}$ & S \\
\hline Parametriocnemus lundbecki & $L, P$ & Plinting & I & & 3 & & 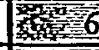 & 1.2 & and \\
\hline Rheocricotopus robacki & $\mathbf{L}$ & 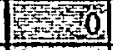 & c & & 3 & $\underline{0}$ & 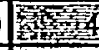 & 0.8 & 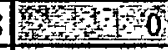 \\
\hline Thienemanniella fusca gp. & L & Fis & c & & 0 & $\mathrm{c}$ & 0 & & 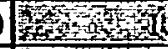 \\
\hline Tvetenia paucunca g & L & 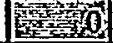 & & & & & X1) & & \\
\hline
\end{tabular}

\begin{tabular}{|c|c|c|c|c|c|c|c|c|c|}
\hline ORDER DIPTERA - (Chironomini) & Stags & Reving & RepB & Kepra & ⿷匚D & Rept & itotar & 1eant? & Qualition \\
\hline Dicrotendipes nr, neomodestus & $\mathrm{L}$ & $x=0$ & 0 & 3 & 1 & $\mathbf{0}$ & $|x|$ & 0.8 & 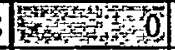 \\
\hline Phaenopsectra flavipes & $\mathrm{L}$ & Fon & 0 & 1 & 0 & $\mathbf{0}$ & 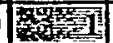 & 0.2 & 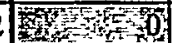 \\
\hline Tribelos jucundum & $\mathrm{L}$ & 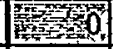 & 2 & 12 & 0 & 0 & 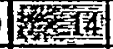 & 2.8 & 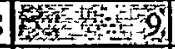 \\
\hline Polypedilum fallax & L & 30 & 0 & 0 & 3 & 0 & 5 & 1.2 & 30 \\
\hline Dolypedilum aviceps & L & & 0 & 1) & 2 & & & 0.6 & \\
\hline
\end{tabular}

\begin{tabular}{|c|c|c|c|c|c|c|c|c|c|}
\hline ORDER DIPTERA - (Tanytarsini) & sage & Beps] & Bep & Repra & 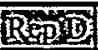 & 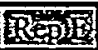 & 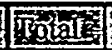 & Vent & Qualifitive \\
\hline Cladotanytarsus sp. & L & 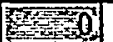 & 0 & 0 & 0 & 0 & 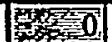 & & 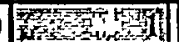 \\
\hline Rheotanytarsus distinctissimus gp. & $\mathbf{L}$ & Fin & 0 & 0 & 0 & 0 & 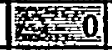 & $\mathbf{0}$ & S10 \\
\hline Tanytarsus & L & 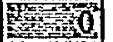 & 2 & 10 & 3 & 0 & 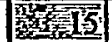 & 3 & Yuty \\
\hline
\end{tabular}

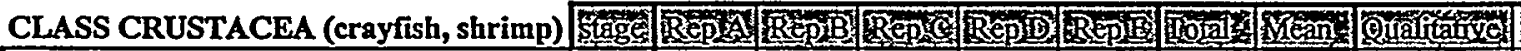

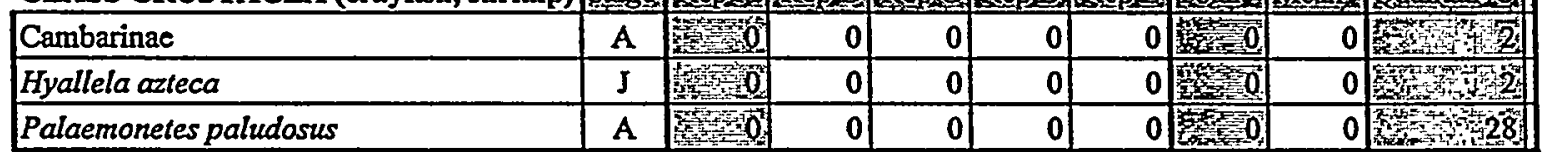

ORDER LEPDOPTERA (moths)

Parapoynx obscuralis

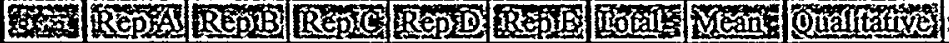

\begin{tabular}{|c|c|c|c|c|c|}
\hline $\mathrm{L}=0$ & 0 & 0 & 0 & $\begin{array}{lll}0 & \\
0 & \end{array}$ & $0 \mid 15$ t \\
\hline
\end{tabular}

\begin{tabular}{|c|c|c|c|c|c|c|c|c|c|}
\hline PHYLUM MOLLUSCA (clams, snails) & 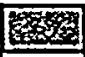 & Reptrat & Rep & Repic & REp & Repin & 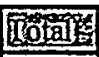 & 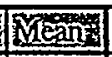 & 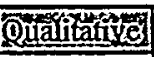 \\
\hline Amnicola limosa & snail & 0 & 1 & 0 & 0 & 0 & $\sqrt{3-1}$ & 0.2 & Pl: \\
\hline Corbicula fluminea & clam & $=0$ & 0 & 0 & 0 & 0 & 0 & 0 & 12 \\
\hline Helisoma anceps & snail & E: $\quad 0$ & 0 & 0 & 0 & 0 & $\therefore 0$ & 0 & 2 \\
\hline Sphaerium & clam & 0 & 1 & 0 & $\mathbf{0}$ & 0 & $r^{2-}$ & 0.2 & 6 \\
\hline & & & & & & & & & \\
\hline
\end{tabular}


Appendix Table B-3. Macroinvertebrate Data, by Replicate

Client: Westinghouse Savannah River Company

Stream: Steel Creek (Site 14)

County: Barnwell, SC

Collection Date: 5 Nov - 8 Dec 1997

Site / \# of Organisms

\begin{tabular}{|c|c|c|c|c|c|c|c|c|c|}
\hline ORDER EPHEMEROPTERA (mayflies) & Syege & Rep & Repin & Rep G & Repal: & epip & 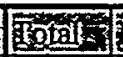 & arean & Quplitative \\
\hline Baetis intercalaris & $\mathbf{N}$ & 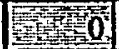 & 0 & 0 & 0 & 1 & 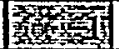 & 0.2 & 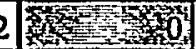 \\
\hline enonema modestum/smithae & $\bar{N}$ & 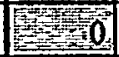 & 8 & 3 & 2 & 9 & 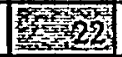 & 4.4 & 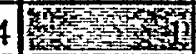 \\
\hline
\end{tabular}

\begin{tabular}{|c|c|c|c|c|c|c|c|c|c|}
\hline ORDER PLECOPTERA (stoneflies) & statage & $\mathrm{Bep}$ & ep & Bed & Reple & Rep & क5 & Mean & Qualitive \\
\hline Cliop & $\mathbf{N}$ & (1) & 1 & 0 & 0 & 1 & 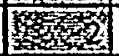 & 0.4 & 12 \\
\hline reniopteryx metequi & $N$ & 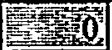 & 0 & 0 & 0 & 13 & 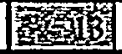 & 2.6 & 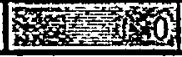 \\
\hline
\end{tabular}

\begin{tabular}{|c|c|c|c|c|c|c|c|c|c|}
\hline ORDER TRICHOPTI & stags & Ren & Repis & Bed & Rep & Rep & efalin & Ein & Qutalituse \\
\hline Cheumatopsyche & $\mathrm{L}$ & 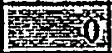 & 0 & 0 & 0 & 0 & Fing & $\overline{0}$ & 18ving \\
\hline Hydropsyche betteni & $\mathrm{L}$ & Sion & 0 & 0 & 0 & $\mathbf{0}$ & X & 0 & 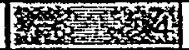 \\
\hline Nectopsyche & $\bar{L}$ & 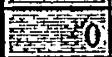 & 0 & 0 & 0 & 0 & 60 & 0 & 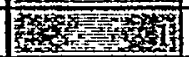 \\
\hline Triaenodes & $\bar{L}$ & ? & 0. & 0 & 0 & 0 & 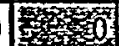 & & 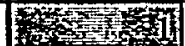 \\
\hline
\end{tabular}

ORDER ODONATA (dragonflies)

\begin{tabular}{|c|c|c|c|c|c|c|c|c|c|}
\hline Boyeria vinosa & $N$ & Stson & 0 & 1 & 0 & 0 & 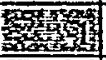 & 0.2 & 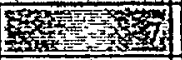 \\
\hline Calopteryx dimidiata & $N$ & 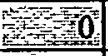 & 0 & 0 & 0 & 0 & 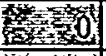 & 0 & Fin \\
\hline Cordulegaster maculata & $N$ & 50 & 0 & 0 & 0 & 0 & String & 0 & 邆 \\
\hline Enallagma sp. $\quad: \quad \cdot$ & $\mathbf{N}$ & 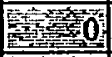 & 0 & 0 & 0 & 0 & Prot & 0 & 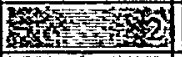 \\
\hline Gomphus lividus & $\mathbf{N}$ & 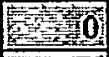 & 0 & 0 & 0 & 0 & 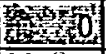 & 0 & 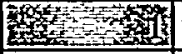 \\
\hline Hagenius brevistylus & $\mathrm{N}$ & 20 & 0 & 0 & 0 & 0 & 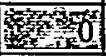 & 0 & 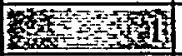 \\
\hline Progomphus & $\mathbf{N}$ & Five & 0 & 0 & 0 & 0 & W & 0 & 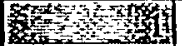 \\
\hline
\end{tabular}

ORDER HETEROPTERA (true bugs) Rhagovelia obesa

stage Rep 称

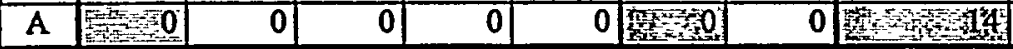


Appendix Table B-3. Macroinvertebrate Data, by Replicate

\section{Client: Westinghouse Savannah River Company}

Stream: Steel Creek (Site 14)

County: Barnwell, SC

Collection Date: 5 Nov - 8 Dec 1997

- Site / \# of Organisms

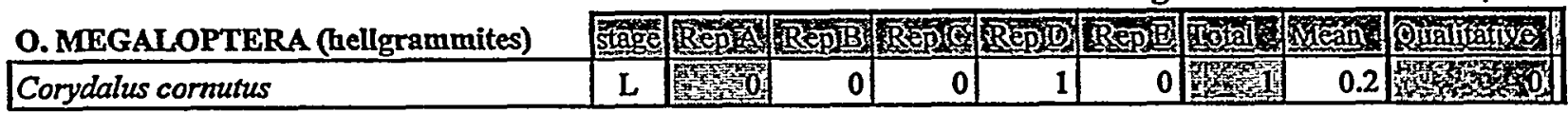

\begin{tabular}{|c|c|c|c|c|c|c|c|c|c|}
\hline ORDER COLEOPTERA (beetles) & Stage & pas & $2 \mathrm{epB}$ & Re & 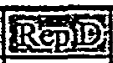 & 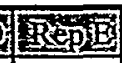 & 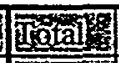 & 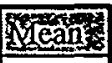 & 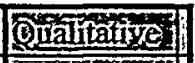 \\
\hline Dineutus discolor & $\mathrm{A}$ & 35 & 0 & 0 & 0 & 0 & Som & 0 & 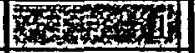 \\
\hline Dineutus ciliatus & A & 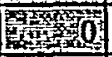 & $\overline{0}$ & 0 & 0 & 0 & Prox & 0 & 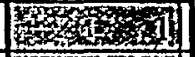 \\
\hline Stenelmis sp. & $\mathrm{L}$ & Whe & $\overline{0}$ & 0 & 0 & 0 & 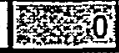 & & 特 \\
\hline
\end{tabular}

\begin{tabular}{|c|c|c|c|c|c|c|c|c|c|}
\hline ORDER DIPTERA - other than midges & stag: & Rep & Rep & Peps & Rep & Repe & gata & gina & Qualiatige \\
\hline Probezzia & $\mathrm{L}$ & Thes & 0 & 0 & 0 & 0 & 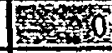 & 0 & 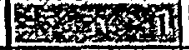 \\
\hline Dixásp. & $\mathrm{L}$ & 19 & 0 & 0 & 0 & 0 & 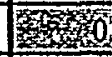 & 0 & 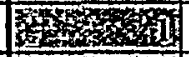 \\
\hline Simulium tuberosum complex & $\mathrm{L}$ & 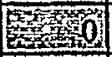 & 0 & $\underline{0}$ & 0 & 1 & 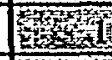 & 0.2 & 2010 \\
\hline Tipula sp. & L & 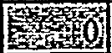 & 0) & 0 & 0 & 0 & $\mathrm{Fp}_{20}$ & 0 & 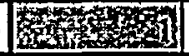 \\
\hline
\end{tabular}

\begin{tabular}{|c|c|c|c|c|c|c|c|c|c|}
\hline ORDER DIPTERA - (Tanypodinae) & stage & Rep & Rep B & RepG & RepD & Rep & 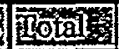 & Mean & Qualifative \\
\hline Ablabesmyia mallochi & $\bar{L}$ & Fin & 0 & 0 & 0 & 0 & W & 0.2 & 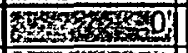 \\
\hline Labrundinia pilosella & L & 要 & 0 & 0 & 1) & 0 & rin & 0.2 & 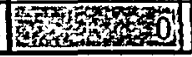 \\
\hline
\end{tabular}

\begin{tabular}{|c|c|c|c|c|c|c|c|c|c|}
\hline ORDER DIPTERA - (O & Sytage & Repis & BepiB & Feps & Rep & Repie & 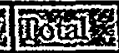 & Leing & Qualtatios \\
\hline Brillia flavifrons & $\overline{\mathrm{L}}$ & gim & 0 & 1 & 0 & 0 & 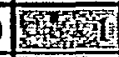 & 0.2 & 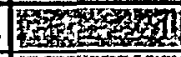 \\
\hline Corynoneura & $\mathrm{L}$ & 6risting & 0 & 0 & 0 & 0 & 20 & 0 & 64 \\
\hline Eukiefferiella claripennis gp. & $\mathrm{L}$ & 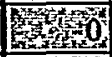 & 0 & 0 & 0 & 0 & $\sqrt{3 x+50}$ & 0 & (x) \\
\hline Parakiefferiella & $\mathrm{L}$ & 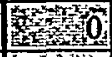 & 0 & 3 & 0 & $\underline{0}$ & troxs & 0.6 & $y_{3 x}$ \\
\hline Parametriocnemus lundbecki & $L, P$ & 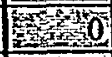 & 0 & 1 & 0 & $\underline{0}$ & 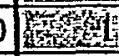 & 0.2 & 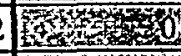 \\
\hline Rheocricotopus robacki & $\mathrm{L}$ & 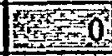 & 0 & 0 & 0 & $\underline{0}$ & tron & 0 & 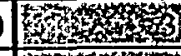 \\
\hline Tvetenia paucunca gp. & L & 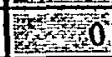 & 0 & 0 & 0 & & 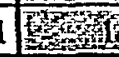 & 0.2 & 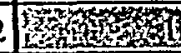 \\
\hline
\end{tabular}

ORDER DIPTÉRA - (Chironomini)

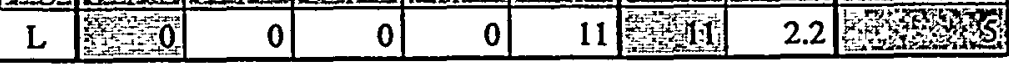


Appendix Table B-3. Macroinvertebrate Data, by Replicate

\section{Client: Westinghouse Savannah River Company}

Stream: Meyers Branch (Site 15)

County: Barnwell, SC

Collection Date: 5 Nov - 8 Dec 1997

Site / \# of Organisms

\begin{tabular}{|c|c|c|c|c|c|c|c|c|c|}
\hline ORDER EPHEMEROPTERA (mayflie & 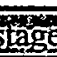 & Pat & Rep & epicin & 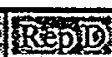 & Rep & Totola & Nean: & Qualifatixe \\
\hline Baetis frondalis & $\mathrm{N}$ & Tis & 0 & 0 & 0 & $\overline{0}$ & 3 & 0 & Wxty \\
\hline Baetis intercalaris & $\mathrm{N}$ & 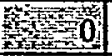 & 0 & 0 & 0 & 0 & 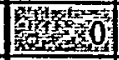 & 0 & $5 x, 4$, \\
\hline Ephemerella (immature / damaged) & $\mathbf{N}$ & WEx & 1 & 0 & 0 & $\overline{0}$ & 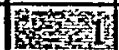 & 0.2 & Wy \\
\hline Eurylophella (immature / damaged) & $\mathrm{N}$ & 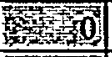 & 0 & 0 & 0 & $\underline{0}$ & 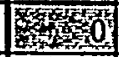 & 0 & 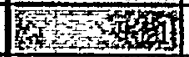 \\
\hline Stenacron interpunctatum & $\mathrm{N}$ & 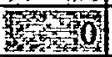 & 0 & 0 & 0 & $\overline{0}$ & 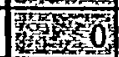 & 0 & $x_{x}+3$ \\
\hline Stenonema modestum/smithae & $\mathbf{N}$ & 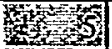 & 3 & 4 & 5 & 5 & 72 & 4.4 & 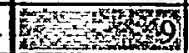 \\
\hline
\end{tabular}

\begin{tabular}{l} 
ORDER PLECOPTERA (stoneflies) \\
\cline { 2 - 9 } \\
\cline { 2 - 8 }
\end{tabular}

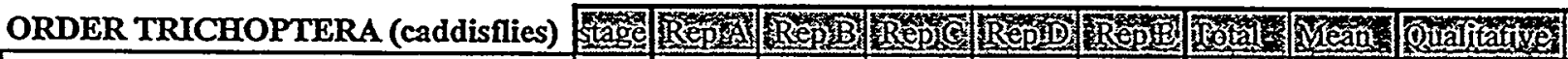

\begin{tabular}{|c|c|c|c|c|c|c|c|c|c|}
\hline Cheumatopsyche & $\mathrm{L}$ & 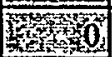 & 0 & 0 & 0 & 3 & 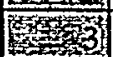 & 0.6 & Fin \\
\hline Chimarra aterrima & $\mathrm{L}$ & 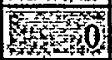 & 0 & 0 & 0 & 0 & 13.700 & 0 & 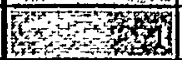 \\
\hline Hydropsyche betteni & $\mathrm{L}$ & tron & 0 & 0 & $\overline{0}$ & $\overline{0}$ & Fis & 0 & Wh \\
\hline Lype diversa & $\mathrm{L}$ & 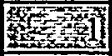 & 0 & 0 & 0 & 0 & (5) & 0.2 & 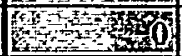 \\
\hline Phylocentropus. & $\mathrm{L}$ & 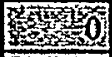 & 0 & 0 & 0 & 0 & 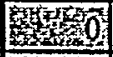 & 0 & 610 \\
\hline Ptilostomis & $\mathrm{L}$ & W & 0 & 0 & 0 & 0 & 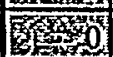 & 0 & 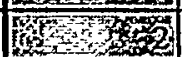 \\
\hline Pycnopsyche sp. & $\mathrm{L}$ & 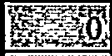 & 0 & 0 & 0 & 0 & gas & 0 & W \\
\hline Triaenodes & $\mathrm{L}$ & 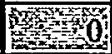 & $\overline{0}$ & 0 & 0 & 0 & 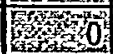 & 0 & mix \\
\hline
\end{tabular}

ORDER ODONATA (dragonflies)

\begin{tabular}{|c|c|c|c|c|c|c|c|c|c|}
\hline Calopteryx dimidiata & $\mathrm{N}$ & 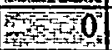 & 0 & 0 & $\overline{0}$ & $\overline{0}$ & 0 & 0 & Fus \\
\hline Cordulegaster maculata & $\bar{N}$ & 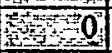 & 0 & 0 & $\overline{0}$ & 0 & $0 \longdiv { 1 8 0 }$ & $\overline{0}$ & Fit \\
\hline Enallagma sp. & $\mathbf{N}$ & Fin & 0 & 0 & $\mathbf{0}$ & & $0 \quad 130$ & 0 & $2 y$ \\
\hline Gomphus lividus & $\mathrm{N}$ & 80 & 0 & 0 & 0 & 0 & $0 \longdiv { 7 0 }$ & 0 & F: \\
\hline
\end{tabular}


Appendix Table B-3. Macroinvertebrate Data, by Replicate

Client: Westinghouse Savannah River Company

Stream: Meyers Branch (Site 15)

County: Barnwell, SC

Collection Date: 5 Nov - 8 Dec 1997

Site / \# of Organisms

\begin{tabular}{|c|c|c|c|c|c|c|c|c|c|}
\hline ORDER COLEOPTERA ( & sese & Rep & Rep B & Repis & Repin & Bepin & Eotar: & Sean & Qualitation \\
\hline Ancyronyx variegatus & $\mathrm{L}, \mathrm{A}$ & rytan & 0 & 0) & 0 & 0 & S130 & 0 & \\
\hline Dubiraphia vittata & A & 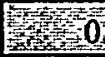 & 0 & 0 & 0 & 0 & 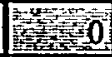 & 0 & 15y \\
\hline Macronychus glabratus & $\mathrm{L}, \mathrm{A}$ & 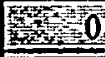 & 0 & 0 & 0 & $\underline{0}$ & 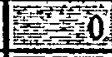 & 0 & 15 \\
\hline Microcylloepus pusillus & A & 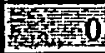 & 0 & 0 & 0 & 0 & 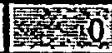 & 0 & 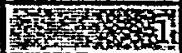 \\
\hline
\end{tabular}

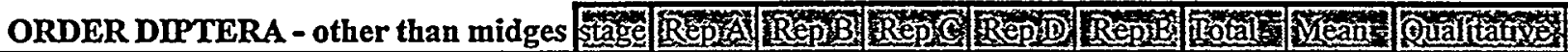

\begin{tabular}{|c|c|c|c|c|c|c|c|c|c|}
\hline Hemerodromia & L & 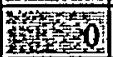 & 이 & 1 & $\mathbf{0}$ & $\mathbf{0}$ & 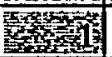 & 0.2 & 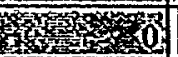 \\
\hline Simulium nr. verecundum & $\mathrm{L}$ & Fin & 0 & 0 & $\mathbf{0}$ & $\underline{0}$ & 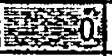 & 0 & \\
\hline Simulium tuberosum complex & L & mons & 0 & $\mathbf{0}$ & 0 & $\mathbf{0}$ & 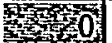 & 0 & ST3 \\
\hline
\end{tabular}

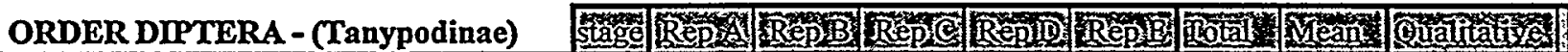

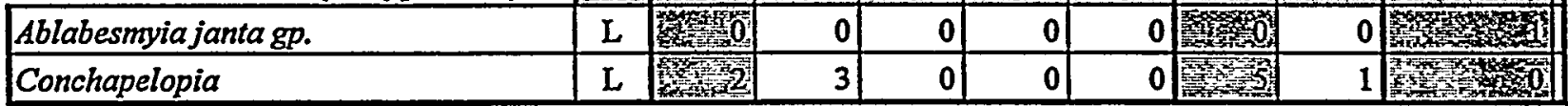

\begin{tabular}{|c|c|c|c|c|c|c|c|c|c|}
\hline ORDER DIPTERA - (Orthoclad & tage & pep & 3ep & Repic & RepiD & Rep & 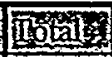 & Eand & Quainative \\
\hline Orthocladius obumbratus & $\mathrm{L}$ & 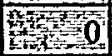 & 0 & 0 & 0 & 0 & 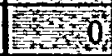 & 0 & 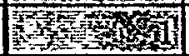 \\
\hline Parametriocnemus lundbecki & $\mathrm{L}, \mathrm{P}$ & 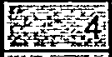 & 2 & 9 & 11 & 11 & sing & 7.4 & 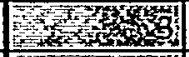 \\
\hline Rheocricotopus robacki & $\mathbf{L}$ & 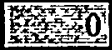 & 0 & 0 & 1 & $\mathbf{0}$ & 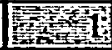 & 0.2 & 8 \\
\hline Thienemanniella xena gp. & $\mathrm{L}$ & $4=0$ & 0 & 0 & $\underline{0}$ & 2 & 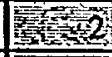 & 0.4 & 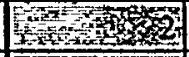 \\
\hline Thienemanniella fusca gp. & $\mathbf{L}$ & 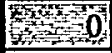 & 0 & 0 & $\mathbf{0}$ & 1 & 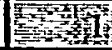 & 0.2 & 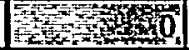 \\
\hline Unniella multivirga & $\mathbf{L}$ & 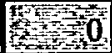 & 0 & 0 & 1 & 1 & 证 & 0.4 & 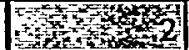 \\
\hline
\end{tabular}

ORDER DIPTERA - (Chironomini)

\begin{tabular}{|c|c|c|c|c|c|c|c|c|c|}
\hline Polypedilum aviceps & L & T100 & 6 & 9 & 17 & $\overline{15}$ & 147 & 9.4 & 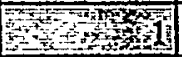 \\
\hline Polypedilum fallax & $\mathrm{L}$ & 0 & 0 & 0 & 0 & 1 & By & 0.2 & 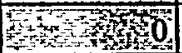 \\
\hline
\end{tabular}


Appendix Table B-3. Macroinvertebrate Data, by Replicate

Client: Westinghouse Savannah River Company

Stream: Meyers Branch (Site 15)

County: Barnwell, SC

Collection Date: 5 Nov - 8 Dec 1997

Site / \# of Organisms

ORDER DIPTERA - (Tanytarsini)

Rheotanytarsus distinctissimus gp.

Tanytarsus

\begin{tabular}{|c|c|c|c|c|c|c|c|}
\hline $\mathrm{agg}$ & Reps & Sep & Sepic & Reg & Rep $\overline{\mathrm{E}}$ & Tiotalu & X cean \\
\hline L & $\begin{array}{ll}3 \\
3\end{array}$ & $\underline{0}$ & 1 & 0 & 3 & 3 & 0.8 \\
\hline $\mathbf{L}$ & 84 & 2 & 0 & 3 & & 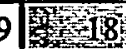 & 3.6 \\
\hline
\end{tabular}

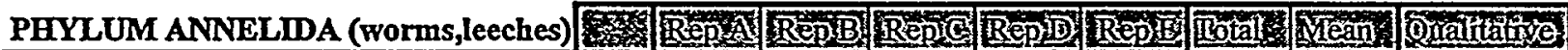

Tubificidae (w/o cap. setae)

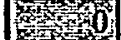

1 $\quad 0$ o 10 of

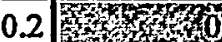

CLASS CRUSTACEA (crayfish, shrim

Cambarinae

Hyallela azteca

Palaemonetes paludosus

\begin{tabular}{|c|c|c|c|c|c|}
\hline & Beps & Rep & Replic & Rep & Rep \\
\hline A & rack & 0 & 0 & 0 & 0 \\
\hline$\overline{\mathbf{J}}$ & Yinge? & 0 & $\overline{0}$ & 0 & $\overline{0}$ \\
\hline$\overline{\mathrm{A}}$ & ⿹ & 0 & $\overline{0}$ & 0 & $\overline{0}$ \\
\hline
\end{tabular}

\begin{tabular}{|c|c|}
\hline otal & Méan \\
\hline 30 & 0 \\
\hline$x^{3} x^{3}$ & 0 \\
\hline 政 & 0 \\
\hline
\end{tabular}

Qualitation

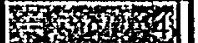

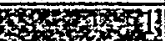

$476>156$

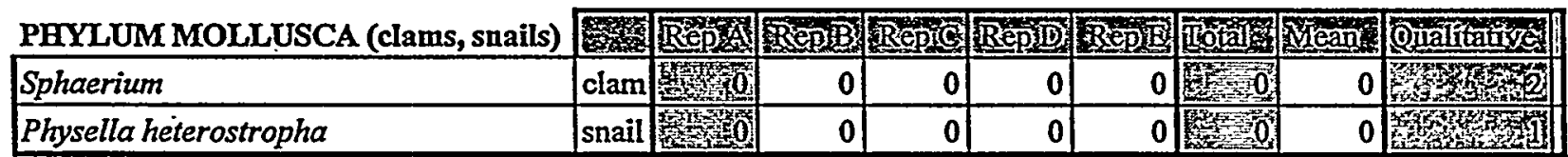




\title{
Appendix Table B-3. Macroinvertebrate Data, by Replicate
}

\author{
Client: Westinghouse Savannah River Company \\ Stream: Four Mile (Site 16) \\ County: Barnwell, SC \\ Collection Date: 5 Nov - 8 Dec 1997
}

Site / \# of Organisms

\begin{tabular}{|c|c|c|c|c|c|c|c|c|c|}
\hline ORDER EPHEMEROPTERA (mayfli & stage & Repse & $\operatorname{Rep}$ & Rejo & RepiD & $R$ p & Dota & Ment? & uầ \\
\hline Callibaetis & $\mathbf{N}$ & 50 & 0 & 요 & 0 & 0 & 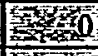 & 足 & $x$ \\
\hline Eurylophella doris & $\mathbf{N}$ & 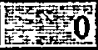 & 8 & 2 & 2 & 2 & ing & 2.8 & 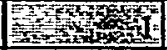 \\
\hline Stenonema modestum/smithae & $\mathbf{N}$ & War & 15 & 9 & 12 & 9 & Fis & 10.6 & 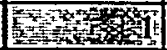 \\
\hline
\end{tabular}

\begin{tabular}{|c|c|c|c|c|c|c|c|c|c|}
\hline ORDER PL & Sage & eps & Ep & Bge & 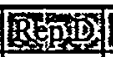 & Ren & Folat & 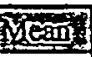 & QIi \\
\hline Paraleuctra sara & $\mathbf{N}$ & 20 & 0 & 0 & 1 & 0 & 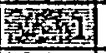 & 0.2 & 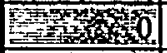 \\
\hline Taeniopteryx metequi & $\mathbf{N}$ & 20 & 이 & 0 & 0) & 0 & 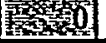 & 0 & 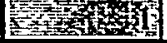 \\
\hline
\end{tabular}

\begin{tabular}{|c|c|c|c|c|c|c|c|c|c|}
\hline ORDER TRICHOPTERA (caddisflies) & Stage & Rep & BepB] & RED M & Bep. & Sept & 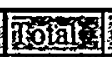 & Eangen & Qnilitative \\
\hline Cernotina spicata & L & 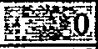 & of & 0) & 1 & 0 & 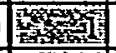 & 0.2 & 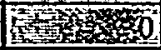 \\
\hline Chetimatopsyche & L & trit & 0 & 0) & 0 & 11 & 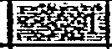 & 0.2 & 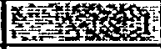 \\
\hline Hydropsyche venularis & $\mathbf{L}$ & 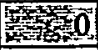 & 0] & 이 & 0 & 2 & 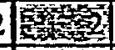 & 0.4 & 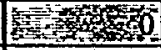 \\
\hline Oxyethira & $\mathrm{L}$ & S & 이 & 이 & 0 & 0 & 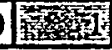 & 0.2 & 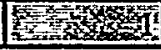 \\
\hline
\end{tabular}

\begin{tabular}{|c|c|c|c|c|c|c|c|c|c|}
\hline ORDER ODONATA (dragonflies) & Strats & Rep & Kep & Repics & Reps: & 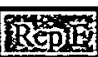 & 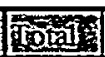 & Man & Qualifarition \\
\hline Argia sedula & $N$ & 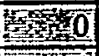 & 0 & 0 & 0 & 0 & 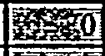 & 0 & 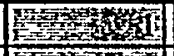 \\
\hline Boyeria vinosa & $\mathbf{N}$ & 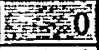 & 0 & 0 & 0 & 0 & 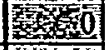 & 0 & 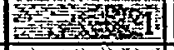 \\
\hline Calopteryx dimidiata & $\mathrm{N}$ & 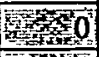 & 0 & 0 & 0 & 0 & 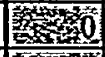 & 0 & 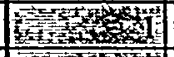 \\
\hline Enallagma sp. & $\mathbf{N}$ & 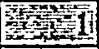 & 0 & 0 & 0 & 0 & 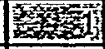 & 0.2 & 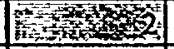 \\
\hline Libellula & $\mathrm{N}$ & 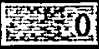 & 0 & 0 & 0 & 0 & rencos & 0 & 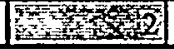 \\
\hline
\end{tabular}

\begin{tabular}{|c|c|c|c|c|c|c|c|}
\hline MEGALOPTH & Stage & PBB] & Repse & pin & Rep国 & & 20.9: \\
\hline orydo & Thi & 0 & 1) & $0 \mid$ & & 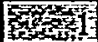 & \\
\hline
\end{tabular}

\begin{tabular}{l} 
ORDER COLEOPTERA (beetles) \\
\cline { 2 - 7 }
\end{tabular}


Appendix Table B-3. Macroinvertebrate Data, by Replicate

Client: Westinghouse Savannah River Company

Stream: Four Mile (Site 16)

County: Barnwell, SC

Collection Date: 5 Nov - 8 Dec 1997

Site / \# of Organisms

\begin{tabular}{|c|c|c|c|c|c|c|c|c|c|}
\hline ORDER DIPTERA - & stage & ept & Bepin & 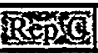 & RCDQ & Eepte & Botal & 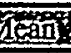 & Q通 \\
\hline$A b l a b$ & L & 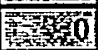 & 0 & 0 & 0 & & 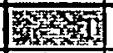 & 0.2 & 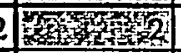 \\
\hline Conchapelopia & L & 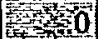 & 0) & 0) & 0 & & 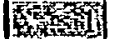 & 0.2 & 2 \\
\hline
\end{tabular}

\begin{tabular}{|c|c|c|c|c|c|c|c|c|c|}
\hline ORDER DIPTERA - (Orthocladiinae) & Ftage & Rep & Rep & Rep:G & Rep & Repa & cotal & Tan & Quilitaxis \\
\hline Corynoneura & $\mathbf{L}$ & 2 & 11 & 1 & 0 & 8 & 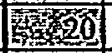 & 4 & po \\
\hline Cricotopus tremulus gp. & $\mathbf{L}$ & Fin & 0 & 0 & 0 & 0 & rimo & $\mathbf{0}$ & 18 \\
\hline Hydrobaenus & $\overline{\mathrm{L}}$ & Btyot & 0 & 1 & 0 & $\mathbf{0}$ & 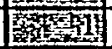 & 0.2 & 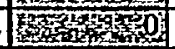 \\
\hline Orthocladius sp. & $\mathbf{L}$ & 14: 180 & 0 & 1 & 0 & 3 & 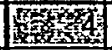 & 0.8 & Pros \\
\hline Orthocladius obumbratus & $\bar{L}$ & 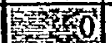 & 0 & 0 & $\overline{0}$ & $\mathbf{0}$ & 缕得0 & & 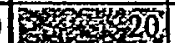 \\
\hline Parakiefferiella & $\overline{\mathrm{L}}$ & 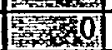 & 16 & 10 & 0 & 10 & 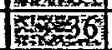 & 7.2 & 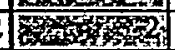 \\
\hline Parametriocnemus lundbecki & $\mathrm{L}, \mathrm{P}$ & Xin & $\overline{7}$ & $\underline{0}$ & $\underline{0}$ & 3 & 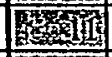 & 2.2 & S \\
\hline Rheocricotopus robacki & $\mathrm{L}$ & 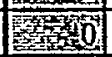 & 2 & 3 & $\underline{0}$ & 1 & 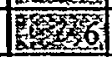 & 1.2 & 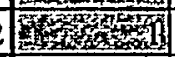 \\
\hline Thienemanniella xena gp. & $\bar{L}$ & 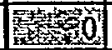 & $\overline{0}$ & 0 & $\overline{0}$ & 0 & 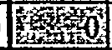 & $\overline{0}$ & Y⿱㇒木幺夊 \\
\hline
\end{tabular}

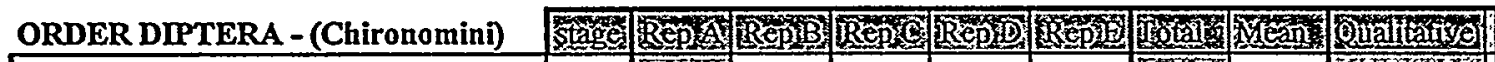

\begin{tabular}{|c|c|c|c|c|c|c|c|c|}
\hline Dicrotendipes nr. neomodestus & $\mathrm{L}$ & 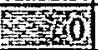 & 1 & 0 & 0 & 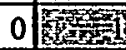 & 0.2 & Xin \\
\hline Polypedilum aviceps & $\bar{L}$ & 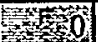 & 0 & 0 & 1 & 10 & 0.4 & 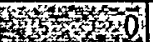 \\
\hline Polypedilum fallax & $\mathrm{L}$ & 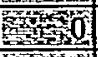 & 1 & 0 & 0 & 0 & 0.2 & $x=0$ \\
\hline Polypedilum illinoense & L & 750 & 0 & 1 & 0 & 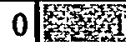 & 0.2 & 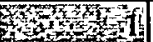 \\
\hline
\end{tabular}

\begin{tabular}{|c|c|c|c|c|c|c|c|c|c|}
\hline ORDER DIPTERA - (Ta & Stage & Rep & $6 \mathrm{p}$ & Repic & epe & Rep & 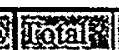 & Mean & Drialitatice \\
\hline Rheotanytarsus distinctissimus gp. & $\mathrm{L}$ & 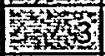 & 3 & 2 & 2 & 12 & 2 & 4.4 & Wron \\
\hline Tanytarsus & L & Pagen & 2 & 8 & 3 & 3 & 3 & 3.2 & 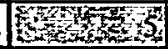 \\
\hline
\end{tabular}

\begin{tabular}{|c|c|c|c|c|c|c|c|c|c|}
\hline CLASS CRUSTACEA (crayfis) & stage & Sep & exis: & REp & Rep & Reper & $6 \mathrm{Et}$ & Sean & \\
\hline $\mathrm{Cam}$ & A & 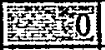 & 0 & 0 & 0 & 0 & 80 & 0 & 15 \\
\hline Hyallela azteca & $\mathrm{J}$ & iting & 1 & 2 & 0 & & 8 & 0.6 & 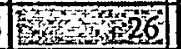 \\
\hline
\end{tabular}

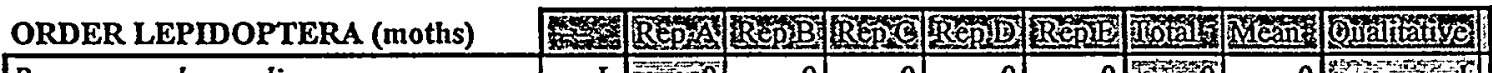

\begin{tabular}{|c|c|c|c|}
\hline Parapoynx obscuralis & $\mathrm{L}=0$ & 0 & \\
\hline
\end{tabular}

\begin{tabular}{|c|c|c|c|c|c|c|c|c|c|}
\hline PHYLUM MOLLUSCA (clams, snails & (X) & Reps & (RepB & Repla & Repin & Rep & total & Mean & Qualitativ \\
\hline Amnicola limosa & snail & $\begin{aligned} 0 \\
-7=0\end{aligned}$ & 1 & 0 & 0 & 0 & Fing & 0.2 & ty \\
\hline $\mathrm{Co}$ & clam & $=1$ & 0 & 0 & 0 & 0 & 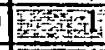 & 0.2 & $A+2=10$ \\
\hline Ferrissia & snail & 0 & 1 & 0 & 0 & 0 & 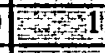 & 0.2 & \\
\hline Gyraulis parvulus & snail & -1 & 0 & 0 & 0 & 0 & 1 & 0.2 & 0 \\
\hline Physella heterostropha & snail & 0 & 0 & & 0 & & 100 & & \\
\hline
\end{tabular}




\section{Appendix Table B-4. Percent Composition by Major Taxonomic Group}

Client: Westinghouse Savannah River Company

Stream: Tims Branch (Site 1)

County: Barnwell, SC

Collection Date: 5 Nov - 8 Dec 1997

\begin{tabular}{|c|c|c|c|c|c|c|c|c|}
\hline W & Rep/2 & Kep & Sepic & RepD & Rép & 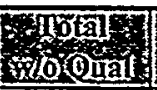 & Mean & Oinititury \\
\hline Annelida (worms) & $16.7 \%$ & $0.0 \%$ & $84.2 \%$ & $0.0 \%$ & $0.0 \%$ & $.25 .8 \%$ & $20.2 \%$ & $2.3 \%$ \\
\hline Mollusca (clams, snails) & $0.0 \%$ & $0.0 \%$ & $0.0 \%$ & $0.0 \%$ & $0.0 \%$ & $0.0 \%$ & $0.0 \%$ & $0.0 \%$ \\
\hline Crustacea (crayfish, shrimp) & $0.0 \%$ & $0.0 \%$ & $0.0 \%$ & $0.0 \%$ & $0.0 \%$ & $0.0 \%$ & $0.0 \%$ & $2.3 \%$ \\
\hline Ephemeroptera & $0.0 \%$ & $0.0 \%$ & $0.0 \%$ & $0.0 \%$ & $14.3 \%$ & $1.5 \%$ & $2.9 \%$ & $0.8 \%$ \\
\hline Plecoptera & $0.0 \%$ & $0.0 \%$ & $0.0 \%$ & $0.0 \%$ & $0.0 \%$ & $0.0 \%$ & $0.0 \%$ & $0.0 \%$ \\
\hline Trichoptera & $16.7 \%$ & $15.8 \%$ & $0.0 \%$ & $13.3 \%$ & $0.0 \%$ & $9.1 \%$ & $9.2 \%$ & $7.0 \%$ \\
\hline Odonata & $0.0 \%$ & $0.0 \%$ & $0.0 \%$ & $0.0 \%$ & $0.0 \%$ & $0.0 \%$ & $0.0 \%$ & $5.5 \%$ \\
\hline Hemiptera & $0.0 \%$ & $0.0 \%$ & $0.0 \%$ & $0.0 \%$ & $0.0 \%$ & $0.0 \%$ & $0.0 \%$ & $0.0 \%$ \\
\hline Coleoptera & $0.0 \%$ & $0.0 \%$ & $0.0 \%$ & $0.0 \%$ & $0.0 \%$ & $0.0 \%$ & $0.0 \%$ & $14.1 \%$ \\
\hline Diptera (excl. midges) & $16.7 \%$ & $42.1 \%$ & $5.3 \%$ & $0.0 \%$ & $71.4 \%$ & $22.7 \%$ & $27.1 \%$ & $12.5 \%$ \\
\hline Diptera (midges) & $33.3 \%$ & $42.1 \%$ & $10.5 \%$ & $86.7 \%$ & $14.3 \%$ & $39.4 \%$ & $37.4 \%$ & $53.9 \%$ \\
\hline
\end{tabular}




\section{Appendix Table B-4. Percent Composition by Major Taxonomic Group}

Client: Westinghouse Savannah River Company

Stream: Upper Three Runs Creek (Site 2)

County: Aiken, SC

Collection Date: 5 Nov - 8 Dec 1997

\begin{tabular}{|c|c|c|c|c|c|c|c|c|}
\hline Whys & Reps & $6 \mathrm{sep}$ & Repos & ReDi & Bepios & Whotakn & 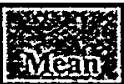 & 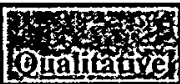 \\
\hline Annelida (worms) & $0.0 \%$ & $0.0 \%$ & $1.0 \%$ & $0.0 \%$ & $0.0 \%$ & . $0.5 \%$ & $0.2 \%$ & $0.0 \%$ \\
\hline Mollusca (clams, snails) & $0.0 \%$ & $0.0 \%$ & $0.0 \%$ & $0.0 \%$ & $0.0 \%$ & $0.0 \%$ & $0.0 \%$ & $2.7 \%$ \\
\hline Crustacea (crayfish, shrimp) & $0.0 \%$ & $0.0 \%$ & $0.0 \%$ & $0.0 \%$ & $0.0 \%$ & $0.0 \%$ & $0.0 \%$ & $2.7 \%$ \\
\hline Ephemeroptera & $24: 3 \%$ & $22.2 \%$ & $4.0 \%$ & $6.5 \%$ & $0.0 \%$ & $11.0 \%$ & $11.4 \%$ & $12.5 \%$ \\
\hline Plecoptera & $16.2 \%$ & $11.1 \%$ & $18.2 \%$ & $22.6 \%$ & $50.0 \%$ & $18.2 \%$ & $23.6 \%$ & $5.5 \%$ \\
\hline Trichoptera & $32.4 \%$ & $2.8 \%$ & $1.0 \%$ & $19.4 \%$ & $0.0 \%$ & $9.6 \%$ & $11.1 \%$ & $31.4 \%$ \\
\hline Odonata & $0.0 \%$ & $0.0 \%$ & $0.0 \%$ & $0.0 \%$ & $0.0 \%$ & $0.0 \%$ & $0.0 \%$ & $3.9 \%$ \\
\hline Hemiptera & $0.0 \%$ & $0.0 \%$ & $0.0 \%$ & $0.0 \%$ & $0.0 \%$ & $0.0 \%$ & $0.0 \%$ & $0.4 \%$ \\
\hline Coleoptera & $2.7 \%$ & $5.6 \%$ & $0.0 \%$ & $3.2 \%$ & $0.0 \%$ & $1.9 \%$ & $2.3 \%$ & $1.2 \%$ \\
\hline Diptera (excl. midges) & $0.0 \%$ & $5.6 \%$ & $0.0 \%$ & $0.0 \%$ & $0.0 \%$ & $1.0 \%$ & $1.1 \%$ & $3.1 \%$ \\
\hline Diptera (midges) & $24.3 \%$ & $52.8 \%$ & $75.8 \%$ & $48.4 \%$ & $50.0 \%$ & $57.9 \%$ & $50.2 \%$ & $32.2 \%$ \\
\hline
\end{tabular}


Appendix Table B-4. Percent Composition by Major Taxonomic Group

Client: Westinghouse Savannah River Company

Stream: Upper Three Runs Creek (Site 3)

County: Aiken, SC

Collection Date: 5 Nov - 8 Dec 1997

\begin{tabular}{|c|c|c|c|c|c|c|c|c|}
\hline $\mathrm{W}_{3}$ & Repis & Rep & Repic & RepDin & 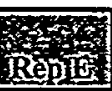 & Totala & iteant & Ouratitative \\
\hline Annelida (worms) & $0.0 \%$ & $0.0 \%$ & $0.0 \%$ & $0.0 \%$ & $0.0 \%$ & $0.0 \%$ & $0.0 \%$ & $0.0 \%$ \\
\hline Mollusca (clams, snails) & $0.0 \%$ & $0.0 \%$ & $0.0 \%$ & $0.0 \%$ & $0.0 \%$ & $0.0 \%$ & $0.0 \%$ & $0.0 \%$ \\
\hline Crustacea (crayfish, shrimp) & $0.0 \%$ & $0.0 \%$ & $0.0 \%$ & $0.0 \%$ & $0.0 \%$ & $0.0 \%$ & $0.0 \%$ & $3.8 \%$ \\
\hline Ephemeroptera & $20.0 \%$ & $10.0 \%$ & $22.2 \%$ & $9.1 \%$ & $2.9 \%$ & $10.7 \%$ & $12.8 \%$ & $6.7 \%$ \\
\hline Plecoptera & $50.0 \%$ & $40.0 \%$ & $27.8 \%$ & $\mathbf{7 2 . 7 \%}$ & $20.0 \%$ & $34.5 \%$ & $42.1 \%$ & $13.5 \%$ \\
\hline Trichoptera & $0.0 \%$ & $0.0 \%$ & $0.0 \%$ & $18.2 \%$ & $51.4 \%$ & $23.8 \%$ & $13.9 \%$ & $19.2 \%$ \\
\hline Odonata & $0.0 \%$ & $0.0 \%$ & $0.0 \%$ & $0.0 \%$ & $2.9 \%$ & $1.2 \%$ & $0.6 \%$ & $11.5 \%$ \\
\hline Hemiptera & $0.0 \%$ & $0.0 \%$ & $0.0 \%$ & $0.0 \%$ & $0.0 \%$ & $0.0 \%$ & $0.0 \%$ & $0.0 \%$ \\
\hline Coleoptera & $0.0 \%$ & $10.0 \%$ & $5.6 \%$ & $0.0 \%$ & $0.0 \%$ & $2.4 \%$ & $3.1 \%$ & $6.7 \%$ \\
\hline Diptera (excl. midges) & $0.0 \%$ & $0.0 \%$ & $11.1 \%$ & $0.0 \%$ & $14.3 \%$ & $8.3 \%$ & $5.1 \%$ & $14.4 \%$ \\
\hline Diptera (midges) & $20.0 \%$ & $40.0 \%$ & $27.8 \%$ & $0.0 \%$ & $8.6 \%$ & $16.7 \%$ & $19.3 \%$ & $15.4 \%$ \\
\hline
\end{tabular}




\section{Appendix Table B-4. Percent Composition by Major Taxonomic Group}

Client: Westinghouse Savannah River Company

Stream: Mill Creek (Site 4)

County: Barnwell, SC

Collection Date: 5 Nov - 8 Dec 1997

\begin{tabular}{|c|c|c|c|c|c|c|c|c|}
\hline S & Res & RepiB & Bep & Rep & Reties & Totals: & ingan & 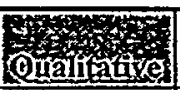 \\
\hline Annelida (worms) & $0.0 \%$ & $0.0 \%$ & $0.0 \%$ & $0.0 \%$ & $0.0 \%$ & $0.0 \%$ & $0.0 \%$ & $0.0 \%$ \\
\hline Mollusca (clams, snails) & $0.0 \%$ & $0.0 \%$ & $0.0 \%$ & $0.0 \%$ & $0.0 \%$ & $0.0 \%$ & $0.0 \%$ & $11.2 \%$ \\
\hline Crustacea (crayfish, shrimp) & $0.0 \%$ & $0.0 \%$ & $0.0 \%$ & $0.0 \%$ & $0.0 \%$ & $0.0 \%$ & $0.0 \%$ & $15.7 \%$ \\
\hline Ephemeroptera & $65.0 \%$ & $42.1 \%$ & $36.4 \%$ & $75.0 \%$ & $62.5 \%$ & $55.4 \%$ & $56.2 \%$ & $13.5 \%$ \\
\hline Plecoptera & $10.0 \%$ & $31.6 \%$ & $36.4 \%$ & $12.5 \%$ & $16.7 \%$ & $21.8 \%$ & $21.4 \%$ & $6.7 \%$ \\
\hline Trichoptera & $10.0 \%$ & $0.0 \%$ & $9.1 \%$ & $6.3 \%$ & $0.0 \%$ & $5.0 \%$ & $5.1 \%$ & $3.4 \%$ \\
\hline Odonata & $0.0 \%$ & $0.0 \%$ & $4.5 \%$ & $0.0 \%$ & $0.0 \%$ & $1.0 \%$ & $0.9 \%$ & $13.5 \%$ \\
\hline Hemiptera & $0.0 \%$ & $0.0 \%$ & $0.0 \%$ & $0.0 \%$ & $0.0 \%$ & $0.0 \%$ & $0.0 \%$ & $0.0 \%$ \\
\hline Coleoptera & $0.0 \%$ & $0.0 \%$ & $0.0 \%$ & $6.3 \%$ & $0.0 \%$ & $1.0 \%$ & $1.3 \%$ & $2.2 \%$ \\
\hline Diptera (ercl.midges) & $0.0 \%$ & $0.0 \%$ & $0.0 \%$ & $0.0 \%$ & $0.0 \%$ & $0.0 \%$ & $0.0 \%$ & $6.7 \%$ \\
\hline Diptera (midges) & $10.0 \%$ & $26.3 \%$ & $9.1 \%$ & $0.0 \%$ & $16.7 \%$ & $12.9 \%$ & $12.4 \%$ & $23.6 \%$ \\
\hline
\end{tabular}


Appendix Table B-4. Percent Composition by Major Taxonomic Group

Client: Westinghouse Savannah River Company

Stream: McQueen Branch (Site 5)

County: Aiken, SC

Collection Date: 5 Nov - 8 Dec 1997

\begin{tabular}{|c|c|c|c|c|c|c|c|c|}
\hline 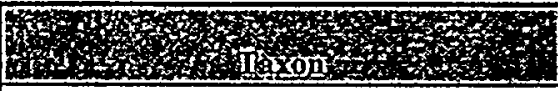 & Rep & Bis & Repes & RepD & Rep as & Prock & Q & 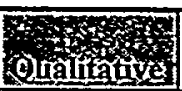 \\
\hline Annelida (worms) & $0.0 \%$ & $0.0 \%$ & $0.0 \%$ & $0.0 \%$ & $0.0 \%$ & $0.0 \%$ & $0.0 \%$ & $0.0 \%$ \\
\hline Mollusca (clams, snails) & $0.0 \%$ & $0.0 \%$ & $0.0 \%$ & $0.0 \%$ & $0.0 \%$ & $0.0 \%$ & $0.0 \%$ & $2.0 \%$ \\
\hline Crustacea (crayfish, shrimp) & $0.0 \%$ & $0.0 \%$ & $0.0 \%$ & $0.0 \%$ & $0.0 \%$ & $0.0 \%$ & $0.0 \%$ & $1.0 \%$ \\
\hline Ephemeroptera & $64.3 \%$ & $69.2 \%$ & $0.0 \%$ & $57.1 \%$ & $81.8 \%$ & $64.6 \%$ & $54.5 \%$ & $12.1 \%$ \\
\hline Plecoptera & $14.3 \%$ & $7.7 \%$ & $0.0 \%$ & $0.0 \%$ & $9.1 \%$ & $8.3 \%$ & $6.2 \%$ & $12.1 \%$ \\
\hline Trichoptera & $7.1 \%$ & $7.7 \%$ & $33.3 \%$ & $14.3 \%$ & 9.1\% & $10.4 \%$ & $14.3 \%$ & $21.2 \%$ \\
\hline Odonata & $0.0 \%$ & $0.0 \%$ & $0.0 \%$ & $0.0 \%$ & $0.0 \%$ & $0.0 \%$ & $0.0 \%$ & $15.2 \%$ \\
\hline Hemiptera & $0.0 \%$ & $0.0 \%$ & $0.0 \%$ & $0.0 \%$ & $0.0 \%$ & $0.0 \%$ & $0.0 \%$ & $1.0 \%$ \\
\hline Coleoptera & $0.0 \%$ & $0.0 \%$ & $0.0 \%$ & $0.0 \%$ & $0.0 \%$ & $0.0 \%$ & $0.0 \%$ & $11.1 \%$ \\
\hline Diptera (excl. midges) & $0.0 \%$ & $0.0 \%$ & $0.0 \%$ & $0.0 \%$ & $0.0 \%$ & $0.0 \%$ & $0.0 \%$ & $5.1 \%$ \\
\hline Diptera (midges) & $7.1 \%$ & $7.7 \%$ & $66.7 \%$ & $28.6 \%$ & $0.0 \%$ & $12.5 \%$ & $22.0 \%$ & $17.2 \%$ \\
\hline
\end{tabular}




\section{Appendix Table B-4. Percent Composition by Major Taxonomic Group}

Client: Westinghouse Savannah River Company

Stream: Crouch Branch (Site 6)

County: Barnwell, SC

Collection Date: 5 Nov - 8 Dec 1997

\begin{tabular}{|c|c|c|c|c|c|c|c|c|}
\hline 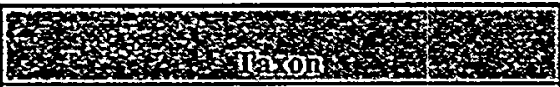 & Rejus & Bep & 3eps & Bep: & Hepis & wototion & 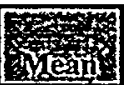 & oralitave \\
\hline Annelida (worms) & $0.0 \%$ & $0.0 \%$ & $0.0 \%$ & $0.0 \%$ & $0.0 \%$ & $0.0 \%$ & $0.0 \%$ & $0.0 \%$ \\
\hline Mollusca (clams, snails) & $0.0 \%$ & $0.0 \%$ & $0.0 \%$ & $0.0 \%$ & $0.0 \%$ & $0.0 \%$ & $0.0 \%$ & $0.0 \%$ \\
\hline Crustacea (crayfish, shrimp) & $0.0 \%$ & $0.0 \%$ & $0.0 \%$ & $0.0 \%$ & $0.0 \%$ & $0.0 \%$ & $0.0 \%$ & $60.0 \%$ \\
\hline Ephemeroptera & $0.0 \%$ & $0.0 \%$ & $0.0 \%$ & $0.0 \%$ & $0.0 \%$ & $0.0 \%$ & $0.0 \%$ & $0.0 \%$ \\
\hline Plecoptera & $0.0 \%$ & $0.0 \%$ & $0.0 \%$ & $0.0 \%$ & $0.0 \%$ & $0.0 \%$ & $0.0 \%$ & $0.0 \%$ \\
\hline Trichoptera & $0.0 \%$ & $0.0 \%$ & $0.0 \%$ & $0.0 \%$ & $0.0 \%$ & $0.0 \%$ & $0.0 \%$ & $0.0 \%$ \\
\hline Odonata & $100.0 \%$ & $0.0 \%$ & $0.0 \%$ & $0.0 \%$ & $20.0 \%$ & $25.0 \%$ & $24.0 \%$ & $0.0 \%$ \\
\hline Hemiptera & $0.0 \%$ & $0.0 \%$ & $0.0 \%$ & $0.0 \%$ & $0.0 \%$ & $0.0 \%$ & $0.0 \%$ & $0.0 \%$ \\
\hline Coleoptera & $0.0 \%$ & $0.0 \%$ & $0.0 \%$ & $0.0 \%$ & $0.0 \%$ & $0.0 \%$ & $0.0 \%$ & $0.0 \%$ \\
\hline Diptera (excl. midges) & $0.0 \%$ & $0.0 \%$ & $0.0 \%$ & $0.0 \%$ & $0.0 \%$ & $0.0 \%$ & $0.0 \%$ & $20.0 \%$ \\
\hline Diptera (midges) & $0.0 \%$ & $0.0 \%$ & $100.0 \%$ & $100.0 \%$ & $80.0 \%$ & $75.0 \%$ & $56.0 \%$ & $20.0 \%$ \\
\hline
\end{tabular}




\section{Appendix Table B-4. Percent Composition by Major Taxonomic Group}

Client: Westinghouse Savannah River Company

Stream: Four Mile Branch (Site 7)

County: Barnwell, SC

Collection Date: 5 Nov - 8 Dec 1997

\begin{tabular}{|c|c|c|c|c|c|c|c|c|}
\hline 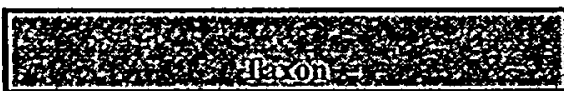 & Besta & Repi & Rep & Rep & Reping & 6rotal & Mean & Oralinges \\
\hline Annelida (worms) & $0.0 \%$ & $0.0 \%$ & $0.0 \%$ & $33.3 \%$ & $0.0 \%$ & $.20 .0 \%$ & $6.7 \%$ & $0.0 \%$ \\
\hline Mollusca (clams, snails) & $0.0 \%$ & $100.0 \%$ & $0.0 \%$ & $0.0 \%$ & $0.0 \%$ & $20.0 \%$ & $20.0 \%$ & $3.1 \%$ \\
\hline Crustacea (crayfish, shrimp) & $0.0 \%$ & $0.0 \%$ & $0.0 \%$ & $0.0 \%$ & $0.0 \%$ & $0.0 \%$ & $0.0 \%$ & $0.0 \%$ \\
\hline Ephemeroptera & $0.0 \%$ & $0.0 \%$ & $0.0 \%$ & $0.0 \%$ & $0.0 \%$ & $0.0 \%$ & $0.0 \%$ & $0.0 \%$ \\
\hline Plecoptera & $0.0 \%$ & $0.0 \%$ & $0.0 \%$ & $0.0 \%$ & $0.0 \%$ & $0.0 \%$ & $0.0 \%$ & $0.0 \%$ \\
\hline Trichoptera & $0.0 \%$ & $0.0 \%$ & $0.0 \%$ & $0.0 \%$ & $0.0 \%$ & $0.0 \%$ & $0.0 \%$ & $0.0 \%$ \\
\hline Odonata & $0.0 \%$ & $0.0 \%$ & $0.0 \%$ & $0.0 \%$ & $0.0 \%$ & $0.0 \%$ & $0.0 \%$ & $0.0 \%$ \\
\hline Hemiptera & $0.0 \%$ & $0.0 \%$ & $0.0 \%$ & $0.0 \%$ & $0.0 \%$ & $0.0 \%$ & $0.0 \%$ & $0.0 \%$ \\
\hline \begin{tabular}{|c|} 
Coleoptera \\
\end{tabular} & $0.0 \%$ & $0.0 \%$ & $0.0 \%$ & $0.0 \%$ & $0.0 \%$ & $0.0 \%$ & $0.0 \%$ & $21.9 \%$ \\
\hline Diptera (excl. midges) & $0.0 \%$ & $0.0 \%$ & $0.0 \%$ & $0.0 \%$ & $100.0 \%$ & $20.0 \%$ & $20.0 \%$ & $15.6 \%$ \\
\hline Diptera (midges) & $0.0 \%$ & $0.0 \%$ & $0.0 \%$ & $66.7 \%$ & $0.0 \%$ & $40.0 \%$ & $13.3 \%$ & $59.4 \%$ \\
\hline
\end{tabular}


Appendix Table B-4. Percent Composition by Major Taxonomic Group

Client: Westinghouse Savannah River Company

Stream: Four Mile Branch (Site 8)

County: Barnwell, SC

Collection Date: 5 Nov - 8 Dec 1997

\begin{tabular}{|c|c|c|c|c|c|c|c|c|}
\hline 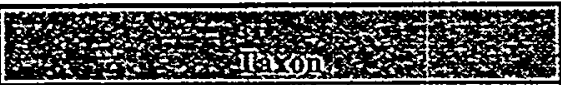 & Rep & Repib & 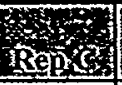 & RépiD & 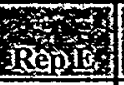 & \%oral & Mesing & Qfalithes \\
\hline Annelida (worms) & $20.0 \%$ & $0.0 \%$ & $33.3 \%$ & $0.0 \%$ & $0.0 \%$ & $.12 .5 \%$ & $10.7 \%$ & $0.0 \%$ \\
\hline Mollusca (clams, snails) & $0.0 \%$ & $0.0 \%$ & $0.0 \%$ & $0.0 \%$ & $0.0 \%$ & $0.0 \%$ & $0.0 \%$ & $13.3 \%$ \\
\hline Crustacea (crayfish, shrimp) & $0.0 \%$ & $0.0 \%$ & $0.0 \%$ & $0.0 \%$ & $0.0 \%$ & $0.0 \%$ & $0.0 \%$ & $0.0 \%$ \\
\hline Ephemeroptera & $0.0 \%$ & $0.0 \%$ & $0.0 \%$ & $0.0 \%$ & $0.0 \%$ & $0.0 \%$ & $0.0 \%$ & $0.0 \%$ \\
\hline Plecoptera & $0.0 \%$ & $0.0 \%$ & $33.3 \%$ & $0.0 \%$ & $0.0 \%$ & $6.3 \%$ & $6.7 \%$ & $0.0 \%$ \\
\hline Trichoptera & $0.0 \%$ & $0.0 \%$ & $0.0 \%$ & $0.0 \%$ & $0.0 \%$ & $0.0 \%$ & $0.0 \%$ & $6.7 \%$ \\
\hline Odonata & $0.0 \%$ & $0.0 \%$ & $0.0 \%$ & $0.0 \%$ & $100.0 \%$ & $6.3 \%$ & $20.0 \%$ & $26.7 \%$ \\
\hline Hemiptera & $0.0 \%$ & $0.0 \%$ & $0.0 \%$ & $0.0 \%$ & $0.0 \%$ & $0.0 \%$ & $0.0 \%$ & $0.0 \%$ \\
\hline Coleoptera & $40.0 \%$ & $0.0 \%$ & $0.0 \%$ & $0.0 \%$ & $0.0 \%$ & $12.5 \%$ & $8.0 \%$ & $6.7 \%$ \\
\hline Diptera (excl. midges) & $0.0 \%$ & $0.0 \%$ & $0.0 \%$ & $0.0 \%$ & $0.0 \%$ & $0.0 \%$ & $0.0 \%$ & $26.7 \%$ \\
\hline Diptera (midges) & $40.0 \%$ & $100.0 \%$ & $33.3 \%$ & $100.0 \%$ & $0.0 \%$ & $62.5 \%$ & $54.7 \%$ & $13.3 \%$ \\
\hline
\end{tabular}




\section{Appendix Table B-4. Percent Composition by Major Taxonomic Group}

Client: Westinghouse Savannah River Company

Stream: Four Mile Branch (Site 9)

County: Barnwell, SC

Collection Date: 5 Nov - 8 Dec 1997

\begin{tabular}{|c|c|c|c|c|c|c|c|c|}
\hline 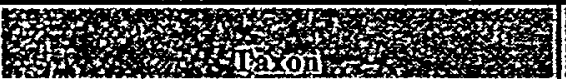 & Reptrits & SRPB & Répict & RepD & Rep & Hogtala & Vien & 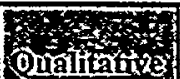 \\
\hline Annelida (worms) & $0.0 \%$ & $0.0 \%$ & $0.0 \%$ & $0.0 \%$ & $0.0 \%$ & $0.0 \%$ & $0.0 \%$ & $0.0 \%$ \\
\hline Mollusca (clams, snails) & $1.9 \%$ & $0.0 \%$ & $2.8 \%$ & $0.0 \%$ & $0.0 \%$ & $1.0 \%$ & $0.9 \%$ & $24.8 \%$ \\
\hline Crustacea (crayfish, shrimp) & $0.0 \%$ & $0.0 \%$ & $0.0 \%$ & $0.0 \%$ & $0.0 \%$ & $0.0 \%$ & $0.0 \%$ & $0.9 \%$ \\
\hline Ephemeroptera & $9.4 \%$ & $5.5 \%$ & $5.6 \%$ & $31.9 \%$ & $9.7 \%$ & $11.1 \%$ & $12.4 \%$ & $28.4 \%$ \\
\hline Plecoptera & $0.0 \%$ & $4.1 \%$ & $1.4 \%$ & $2.1 \%$ & $6.5 \%$ & $2.9 \%$ & $2.8 \%$ & $13.8 \%$ \\
\hline Trichoptera & $79.2 \%$ & $79.5 \%$ & $83.3 \%$ & $53.2 \%$ & $43.5 \%$ & $69.1 \%$ & $67.8 \%$ & $11.0 \%$ \\
\hline Odonata & $0.0 \%$ & $0.0 \%$ & $0.0 \%$ & $0.0 \%$ & $0.0 \%$ & $0.0 \%$ & $0.0 \%$ & $4.6 \%$ \\
\hline Hemiptera & $0.0 \%$ & $0.0 \%$ & $0.0 \%$ & $0.0 \%$ & $0.0 \%$ & $0.0 \%$ & $0.0 \%$ & $0.0 \%$ \\
\hline Coleoptera & $0.0 \%$ & $4.1 \%$ & $2.8 \%$ & $2.1 \%$ & $1.6 \%$ & $2.3 \%$ & $2.1 \%$ & $0.0 \%$ \\
\hline Diptera (excl. midges) & $5.7 \%$ & $1.4 \%$ & $1.4 \%$ & $2.1 \%$ & $25.8 \%$ & $7.2 \%$ & $7.3 \%$ & $6.4 \%$ \\
\hline Diptera (midges) & $3.8 \%$ & $5.5 \%$ & $2.8 \%$ & $8.5 \%$ & $11.3 \%$ & $6.2 \%$ & $6.4 \%$ & $9.2 \%$ \\
\hline
\end{tabular}


Appendix Table B-4. Percent Composition by Major Taxonomic Group

Client: Westinghouse Savannah River Company

Stream: Pen Branch (Site 10)

County: Barnwell, SC

Collection Date: 5 Nov - 8 Dec 1997

\begin{tabular}{|c|c|c|c|c|c|c|c|c|}
\hline \begin{tabular}{|l} 
\\
6
\end{tabular} & Rep & RepiB & Repscis & 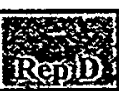 & Hed & 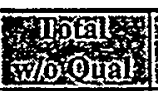 & and & 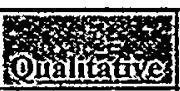 \\
\hline Annelida (worms) & $0.0 \%$ & $0.0 \%$ & $0.0 \%$ & $0.0 \%$ & $0.0 \%$ & $.0 .0 \%$ & $0.0 \%$ & $1.3 \%$ \\
\hline Mollusca (clams, snails) & $0.0 \%$ & $0.0 \%$ & $0.0 \%$ & $0.0 \%$ & $0.0 \%$ & $0.0 \%$ & $-0.0 \%$ & $8.4 \%$ \\
\hline Crustacea (craylish, shrimp) & $0.0 \%$ & $0.0 \%$ & $0.0 \%$ & $0.0 \%$ & $0.0 \%$ & $0.0 \%$ & $0.0 \%$ & $1.9 \%$ \\
\hline Ephemeroptera & $81.8 \%$ & $50.0 \%$ & $57.1 \%$ & $68.4 \%$ & $57.6 \%$ & $62.5 \%$ & $63.0 \%$ & $10.3 \%$ \\
\hline Plecoptera & $13.6 \%$ & $12.5 \%$ & $35.7 \%$ & $15.8 \%$ & $9.1 \%$ & $15.2 \%$ & $17.3 \%$ & $9.7 \%$ \\
\hline Trichoptera & $0.0 \%$ & $0.0 \%$ & $0.0 \%$ & $0.0 \%$ & $0.0 \%$ & $0.0 \%$ & $0.0 \%$ & $4.5 \%$ \\
\hline Odonata & $0.0 \%$ & $4.2 \%$ & $0.0 \%$ & $0.0 \%$ & $3.0 \%$ & $1.8 \%$ & $1.4 \%$ & $7.7 \%$ \\
\hline Hemiptera & $0.0 \%$ & $0.0 \%$ & $0.0 \%$ & $0.0 \%$ & $0.0 \%$ & $0.0 \%$ & $0.0 \%$ & $0.0 \%$ \\
\hline Coleoptera & $0.0 \%$ & $0.0 \%$ & $0.0 \%$ & $0.0 \%$ & $0.0 \%$ & $0.0 \%$ & $0.0 \%$ & $3.2 \%$ \\
\hline Diptera (excl. midges) & $0.0 \%$ & $0.0 \%$ & $0.0 \%$ & $0.0 \%$ & $0.0 \%$ & $0.0 \%$ & $0.0 \%$ & $1.3 \%$ \\
\hline Diptera (midges) & $4.5 \%$ & $33.3 \%$ & $7.1 \%$ & $15.8 \%$ & $30.3 \%$ & $20.5 \%$ & $18.2 \%$ & $51.6 \%$ \\
\hline
\end{tabular}


Appendix Table B-4. Percent Composition by Major Taxonomic Group

Client: Westinghouse Savannah River Company

Stream: Pen Branch (Site 11)

County: Barnwell, SC

Collection Date: 5 Nov - 8 Dec 1997

\begin{tabular}{|c|c|c|c|c|c|c|c|c|}
\hline 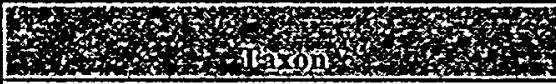 & Rep & RepiB & Retion & Repio & Repig & Hotala & Meni & Qualitaxio \\
\hline Annelida (worms) & $0.0 \%$ & $0.0 \%$ & $0.0 \%$ & $0.0 \%$ & $0.0 \%$ & $0.0 \%$ & $0.0 \%$ & $0.0 \%$ \\
\hline Mollusca (clams, snails) & $0.0 \%$ & $0.0 \%$ & $0.0 \%$ & $1.5 \%$ & $0.0 \%$ & $0.7 \%$ & $0.3 \%$ & $6.3 \%$ \\
\hline Crustacea (crayfish, shrimp) & $0.0 \%$ & $0.0 \%$ & $3.8 \%$ & $0.0 \%$ & $0.0 \%$ & $0.7 \%$ & $0.8 \%$ & $21.3 \%$ \\
\hline Ephemeroptera & $78.6 \%$ & $46.7 \%$ & $69.2 \%$ & $34.3 \%$ & $30.0 \%$ & $46.9 \%$ & $51.8 \%$ & $10.0 \%$ \\
\hline Plecoptera & $7.1 \%$ & $20.0 \%$ & $19.2 \%$ & $19.4 \%$ & $40.0 \%$ & $19.7 \%$ & $21.2 \%$ & $7.5 \%$ \\
\hline Trichoptera & $0.0 \%$ & $3.3 \%$ & $0.0 \%$ & $25.4 \%$ & $0.0 \%$ & $12.2 \%$ & $5.7 \%$ & $6.3 \%$ \\
\hline Odonata & $0.0 \%$ & $0.0 \%$ & $0.0 \%$ & $0.0 \%$ & $0.0 \%$ & $0.0 \%$ & $0.0 \%$ & $17.5 \%$ \\
\hline Hemiptera & $0.0 \%$ & $0.0 \%$ & $0.0 \%$ & $0.0 \%$ & $0.0 \%$ & $0.0 \%$ & $0.0 \%$ & $1.3 \%$ \\
\hline Coleoptera & $14.3 \%$ & $3.3 \%$ & $3.8 \%$ & $4.5 \%$ & $0.0 \%$ & $4.8 \%$ & $5.2 \%$ & $5.0 \%$ \\
\hline Diptera (excl. midges) & $0.0 \%$ & $0.0 \%$ & $0.0 \%$ & $0.0 \%$ & $0.0 \%$ & $0.0 \%$ & $0.0 \%$ & $5.0 \%$ \\
\hline Diptera (midges) & $0.0 \%$ & $26.7 \%$ & $3.8 \%$ & $14.9 \%$ & $30.0 \%$ & $15.0 \%$ & $15.1 \%$ & $17.5 \%$ \\
\hline
\end{tabular}


Appendix Table B-4. Percent Composition by Major Taxonomic Group

Client: Westinghouse Savannah River Company

Stream: Indian Grave Branch (Site 12)

County: Barnwell, SC

Collection Date: 5 Nov - 8 Dec 1997

\begin{tabular}{|c|c|c|c|c|c|c|c|c|}
\hline 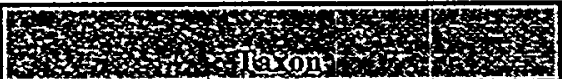 & sets & $\mathrm{Rep}$ & Bepts & RepD & Rét & Whoinal & Wean & Quation \\
\hline Annelida (worms) & $0.0 \%$ & $0.0 \%$ & $0.0 \%$ & $6.3 \%$ & $0.0 \%$ & $1.1 \%$ & $1.3 \%$ & $1.3 \%$ \\
\hline Mollusca (clams, snails) & $0.0 \%$ & $0.0 \%$ & $2.6 \%$ & $0.0 \%$ & $0.0 \%$ & $1.1 \%$ & $0.5 \%$ & $10.3 \%$ \\
\hline Crustacea (crayfish, shrimp) & $.11 .1 \%$ & $0.0 \%$ & $0.0 \%$ & $0.0 \%$ & $0.0 \%$ & $1.1 \%$ & $2.2 \%$ & $48.7 \%$ \\
\hline Ephemeroptera & $33.3 \%$ & $0.0 \%$ & $30.8 \%$ & $25.0 \%$ & $58.3 \%$ & $28.6 \%$ & $29.5 \%$ & $6.4 \%$ \\
\hline Plecoptera & $0.0 \%$ & $0.0 \%$ & $0.0 \%$ & $0.0 \%$ & $0.0 \%$ & $0.0 \%$ & $0.0 \%$ & $0.0 \%$ \\
\hline Trichoptera & $0.0 \%$ & $0.0 \%$ & $0.0 \%$ & $6.3 \%$ & $8.3 \%$ & $2.2 \%$ & $2.9 \%$ & $9.0 \%$ \\
\hline Odonata & $0.0 \%$ & $0.0 \%$ & $2.6 \%$ & $6.3 \%$ & $0.0 \%$ & $2.2 \%$ & $1.8 \%$ & $2.6 \%$ \\
\hline Hemiptera & $0.0 \%$ & $0.0 \%$ & $0.0 \%$ & $0.0 \%$ & $0.0 \%$ & $0.0 \%$ & $0.0 \%$ & $1.3 \%$ \\
\hline Coleoptera & $11.1 \%$ & $6.7 \%$ & $2.6 \%$ & $0.0 \%$ & $0.0 \%$ & $3.3 \%$ & $4.1 \%$ & $0.0 \%$ \\
\hline Diptera (excl. midges) & $0.0 \%$ & $0.0 \%$ & $0.0 \%$ & $0.0 \%$ & $0.0 \%$ & $0.0 \%$ & $0.0 \%$ & $2.6 \%$ \\
\hline Diptera (midges) & $44.4 \%$ & $93.3 \%$ & $61.5 \%$ & $56.3 \%$ & $33.3 \%$ & $60.4 \%$ & $57.8 \%$ & $17.9 \%$ \\
\hline
\end{tabular}


Appendix Table B-4. Percent Composition by Major Taxonomic Group

Client: Westinghouse Savannah River Company

Stream: Pen Branch (Site 13)

County: Barnwell, SC

Collection Date: 5 Nov - 8 Dec 1997

\begin{tabular}{|c|c|c|c|c|c|c|c|c|}
\hline Why & Rep & ReB & Repo & kepio & $\begin{array}{l}\text { Pepis } \\
\text { Repis }\end{array}$ & Fiontạle & Mean & Oublitative \\
\hline Annelida (worms) & $0.0 \%$ & $0.0 \%$ & $0.0 \%$ & $0.0 \%$ & $0.0 \%$ & $0.0 \%$ & $0.0 \%$ & $0.0 \%$ \\
\hline Mollusca (clams, snails) & $0.0 \%$ & $20.0 \%$ & $0.0 \%$ & $0.0 \%$ & $0.0 \%$ & $2.3 \%$ & $4.0 \%$ & $19.4 \%$ \\
\hline Crustacea (crayfish, shrimp) & $0.0 \%$ & $0.0 \%$ & $0.0 \%$ & $0.0 \%$ & $0.0 \%$ & $0.0 \%$ & $0.0 \%$ & $29.6 \%$ \\
\hline Ephemeroptera & $0.0 \%$ & $10.0 \%$ & $0.0 \%$ & $21.4 \%$ & $20.0 \%$ & $9.3 \%$ & $10.3 \%$ & $2.8 \%$ \\
\hline Plecoptera & $0.0 \%$ & $0.0 \%$ & $0.0 \%$ & $0.0 \%$ & $0.0 \%$ & $0.0 \%$ & $0.0 \%$ & $0.0 \%$ \\
\hline Trichoptera & $0.0 \%$ & $0.0 \%$ & $0.0 \%$ & $10.7 \%$ & $0.0 \%$ & $3.5 \%$ & $2.1 \%$ & $7.4 \%$ \\
\hline Odonata & $25.0 \%$ & $20.0 \%$ & $0.0 \%$ & $0.0 \%$ & $0.0 \%$ & $3.5 \%$ & $9.0 \%$ & $5.6 \%$ \\
\hline Hemipter & $0.0 \%$ & $0.0 \%$ & $0.0 \%$ & $0.0 \%$ & $0.0 \%$ & $0.0 \%$ & $0.0 \%$ & $0.0 \%$ \\
\hline Coleoptera & $0.0 \%$ & $0.0 \%$ & $0.0 \%$ & $3.6 \%$ & $20.0 \%$ & $2.3 \%$ & $4.7 \%$ & $0.0 \%$ \\
\hline Diptera (excl. midges) & $0.0 \%$ & $0.0 \%$ & $0.0 \%$ & $0.0 \%$ & $0.0 \%$ & $0.0 \%$ & $0.0 \%$ & $0.0 \%$ \\
\hline Diptera (midges) & $75.0 \%$ & $50.0 \%$ & $100.0 \%$ & $60.7 \%$ & $40.0 \%$ & $76.7 \%$ & $65.1 \%$ & $34.3 \%$ \\
\hline
\end{tabular}




\section{Appendix Table B-4. Percent Composition by Major Taxonomic Group}

Client: Westinghouse Savannah River Company

Stream: Steel Creek (Site 14)

County: Barnwell, SC

Collection Date: 5 Nov - 8 Dec 1997

\begin{tabular}{|c|c|c|c|c|c|c|c|c|}
\hline 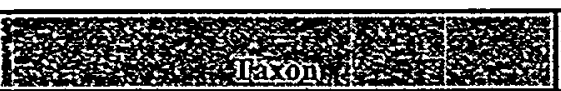 & Mep 1 & Retion & Rep C & RepD & Repin & 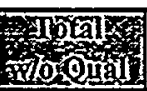 & 3ean & 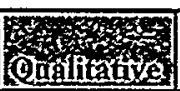 \\
\hline Annelida (worms) & $0.0 \%$ & $0.0 \%$ & $0.0 \%$ & $0.0 \%$ & $0.0 \%$ & $0.0 \%$ & $0.0 \%$ & $0.0 \%$ \\
\hline Mollusca (clams, snails) & $0.0 \%$ & $10.0 \%$ & $0.0 \%$ & $20.0 \%$ & $0.0 \%$ & $3.1 \%$ & $6.0 \%$ & $4.0 \%$ \\
\hline Crustacea (crayfish, shrimp) & $0.0 \%$ & $0.0 \%$ & $0.0 \%$ & $0.0 \%$ & $0.0 \%$ & $0.0 \%$ & $0.0 \%$ & $14.0 \%$ \\
\hline Ephemeroptera & $0.0 \%$ & $80.0 \%$ & $33.3 \%$ & $40.0 \%$ & $25.6 \%$ & $35.9 \%$ & $35.8 \%$ & $1.0 \%$ \\
\hline Plecoptera & $0.0 \%$ & $10.0 \%$ & $0.0 \%$ & $0.0 \%$ & $35.9 \%$ & $23.4 \%$ & $9.2 \%$ & $2.0 \%$ \\
\hline Trichoptera & $0.0 \%$ & $0.0 \%$ & $0.0 \%$ & $0.0 \%$ & $0.0 \%$ & $0.0 \%$ & $0.0 \%$ & $12.0 \%$ \\
\hline Odonata & $0.0 \%$ & $0.0 \%$ & $11.1 \%$ & $0.0 \%$ & $0.0 \%$ & $1.6 \%$ & $2.2 \%$ & $23.0 \%$ \\
\hline Hemiptera & $0.0 \%$ & $0.0 \%$ & $0.0 \%$ & $0.0 \%$ & $0.0 \%$ & $0.0 \%$ & $0.0 \%$ & $14.0 \%$ \\
\hline Coleoptera & $0.0 \%$ & $0.0 \%$ & $0.0 \%$ & $0.0 \%$ & $0.0 \%$ & $0.0 \%$ & $0.0 \%$ & $8.0 \%$ \\
\hline Diptera (excl. midges) & $0.0 \%$ & $0.0 \%$ & $0.0 \%$ & $0.0 \%$ & $2.6 \%$ & $1.6 \%$ & $0.5 \%$ & $4.0 \%$ \\
\hline Diptera (midges) & $100.0 \%$ & $0.0 \%$ & $55.6 \%$ & $20.0 \%$ & $35.9 \%$ & $32.8 \%$ & $42.3 \%$ & $17.0 \%$ \\
\hline
\end{tabular}




\section{Appendix Table B-4. Percent Composition by Major Taronomic Group}

Client: Westinghouse Savannah River Company

Stream: Meyers Branch (Site 15)

County: Barnwell, SC

Collection Date: 5 Nov - 8 Dec 1997

\begin{tabular}{|c|c|c|c|c|c|c|c|c|}
\hline F\% & Rè & DepiB & Repris & RepD & Repia & 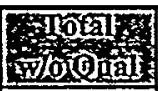 & 1) & $\begin{array}{l}0 \\
\text { Qugitative }\end{array}$ \\
\hline Annelida (worms) & $0.0 \%$ & $4.2 \%$ & $0.0 \%$ & $0.0 \%$ & $0.0 \%$ & . $0.6 \%$ & $0.8 \%$ & $0.0 \%$ \\
\hline Mollusca (clams, snails) & $0.0 \%$ & $0.0 \%$ & $0.0 \%$ & $0.0 \%$ & $0.0 \%$ & $0.0 \%$ & $0.0 \%$ & $3.1 \%$ \\
\hline Crustacea (crayfish, shrimp) & $0.0 \%$ & $0.0 \%$ & $0.0 \%$ & $0.0 \%$ & $0.0 \%$ & $0.0 \%$ & $0.0 \%$ & $21.6 \%$ \\
\hline Ephemeroptera & $27.8 \%$ & $16.7 \%$ & $15.4 \%$ & $12.5 \%$ & $9.3 \%$ & $14.2 \%$ & $16.3 \%$ & $18.6 \%$ \\
\hline Plecoptera & $11.1 \%$ & $25.0 \%$ & $7.7 \%$ & $5.0 \%$ & $5.6 \%$ & $9.3 \%$ & $10.9 \%$ & $11.3 \%$ \\
\hline Trichoptera & $5.6 \%$ & $0.0 \%$ & $0.0 \%$ & $0.0 \%$ & $5.6 \%$ & $2.5 \%$ & $2.2 \%$ & $9.3 \%$ \\
\hline Odonata & $0.0 \%$ & $0.0 \%$ & $0.0 \%$ & $0.0 \%$ & $0.0 \%$ & $0.0 \%$ & $0.0 \%$ & $7.2 \%$ \\
\hline Hemiptera & $0.0 \%$ & $0.0 \%$ & $0.0 \%$ & $0.0 \%$ & $0.0 \%$ & $0.0 \%$ & $0.0 \%$ & $0.0 \%$ \\
\hline Coleoptera & $0.0 \%$ & $0.0 \%$ & $0.0 \%$ & $0.0 \%$ & $0.0 \%$ & $0.0 \%$ & $0.0 \%$ & $5.2 \%$ \\
\hline Diptera (excl. midges) & $0.0 \%$ & $0.0 \%$ & $3.8 \%$ & $0.0 \%$ & $0.0 \%$ & $0.6 \%$ & $0.8 \%$ & $3.1 \%$ \\
\hline Diptera (midges) & $55.6 \%$ & $54.2 \%$ & $73.1 \%$ & $82.5 \%$ & $79.6 \%$ & $72.8 \%$ & $69.0 \%$ & $20.6 \%$ \\
\hline
\end{tabular}


Appendix Table B-4. Percent Composition by Major Taxonomic Group

Client: Westinghouse Savannah River Company

Stream: Four Mile (Site 10)

County: Barnwell, SC

Collection Date: 5 Nov - 8 Dec 1997

\begin{tabular}{|c|c|c|c|c|c|c|c|c|}
\hline 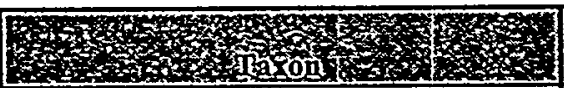 & Repas & $\mathrm{Rep}$ & Repdo & Repion & Rêpin & 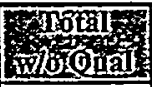 & ivean & Oulitatio \\
\hline Annelida (worms) & $0.0 \%$ & $0.0 \%$ & $0.0 \%$ & $0.0 \%$ & $0.0 \%$ & $0.0 \%$ & $0.0 \%$ & $0.0 \%$ \\
\hline Mollusca (clams, snails) & $11.8 \%$ & $2.9 \%$ & $0.0 \%$ & $0.0 \%$ & $0.0 \%$ & $1.9 \%$ & $2.9 \%$ & $16.7 \%$ \\
\hline Crustacea (crayfish, shrimp) & $0.0 \%$ & $1.4 \%$ & $4.9 \%$ & $0.0 \%$ & $0.0 \%$ & $1.5 \%$ & $1.3 \%$ & $28.1 \%$ \\
\hline Ephemeroptera & $47.1 \%$ & $33.3 \%$ & $26.8 \%$ & $63.6 \%$ & $19.3 \%$ & $32.5 \%$ & $38.0 \%$ & $3.1 \%$ \\
\hline Plecoptera & $0.0 \%$ & $0.0 \%$ & $0.0 \%$ & $4.5 \%$ & $0.0 \%$ & $0.5 \%$ & $0.9 \%$ & $1.0 \%$ \\
\hline Trichoptera & $5.9 \%$ & $0.0 \%$ & $0.0 \%$ & $4.5 \%$ & $5.3 \%$ & $2.4 \%$ & $3.1 \%$ & $2.1 \%$ \\
\hline Odonata & $5.9 \%$ & $0.0 \%$ & $0.0 \%$ & $0.0 \%$ & $0.0 \%$ & $0.5 \%$ & $1.2 \%$ & $7.3 \%$ \\
\hline Hemiptera & $0.0 \%$ & $0.0 \%$ & $0.0 \%$ & $0.0 \%$ & $0.0 \%$ & $0.0 \%$ & $0.0 \%$ & $0.0 \%$ \\
\hline Coleoptera & $5.9 \%$ & $0.0 \%$ & $0.0 \%$ & $0.0 \%$ & $0.0 \%$ & $0.5 \%$ & $1.2 \%$ & $0.0 \%$ \\
\hline Diptera (excl. midges) & $0.0 \%$ & $0.0 \%$ & $0.0 \%$ & $0.0 \%$ & $0.0 \%$ & $0.0 \%$ & $0.0 \%$ & $0.0 \%$ \\
\hline Diptera (midges) & $23.5 \%$ & $62.3 \%$ & $65.9 \%$ & $27.3 \%$ & $75.4 \%$ & $59.7 \%$ & $50.9 \%$ & $40.6 \%$ \\
\hline
\end{tabular}




\section{Appendix Table B-5. Functional Feeding Group Analysis}

Client: Westinghouse Savannah River Company

Stream: Tims Branch (Site 1)

County: Barnwell, SC

Collection Date: 5 Nov - 8 Dec 1997

Analysis by Number of Organisms

\begin{tabular}{|c|c|c|c|c|c|c|c|c|}
\hline \% & Bep & Repas & Reptits & Rep & Rep & \% & Hean & Oualitative \\
\hline Collector - Gatherers & $33.3 \%$ & $7.9 \%$ & $86.8 \%$ & $26.7 \%$ & $7.1 \%$ & $.37 .1 \%$ & $32.4 \%$ & $19.5 \%$ \\
\hline Collector - Filterers & $50.0 \%$ & $78.9 \%$ & $10.5 \%$ & $33.3 \%$ & $71.4 \%$ & $45.5 \%$ & $48.8 \%$ & $46.9 \%$ \\
\hline Predators & $16.7 \%$ & $10.5 \%$ & $0.0 \%$ & $33.3 \%$ & $0.0 \%$ & $12.1 \%$ & $12.1 \%$ & $24.6 \%$ \\
\hline Scra & $0.0 \%$ & $0.0 \%$ & $0.0 \%$ & $0.0 \%$ & $7.1 \%$ & $0.8 \%$ & $1.4 \%$ & $0.8 \%$ \\
\hline Shredders & $0.0 \%$ & $2.6 \%$ & $2.6 \%$ & $6.7 \%$ & $14.3 \%$ & $4.5 \%$ & $5.2 \%$ & $8.2 \%$ \\
\hline
\end{tabular}

Analysis by Biomass

\begin{tabular}{|c|c|c|c|c|c|c|c|}
\hline 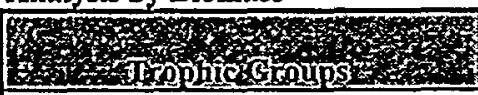 & Wysys & S & 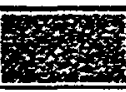 & sos & $\begin{array}{l}\text { sotal } \\
\text { wionain }\end{array}$ & $y^{-39}$ & 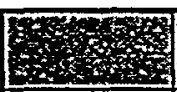 \\
\hline Collector-Gatherers & 8 & & & & $0.3 \%$ & & \\
\hline Collector - Filterers & & & & & $0.8 \%$ & & \\
\hline Predators & & & & & $98.9 \%$ & & \\
\hline Scrapers & & & & & $<0.1 \%$ & & \\
\hline Shredders & & & & & $<0.1 \%$ & & \\
\hline
\end{tabular}


Appendix Table B-5. Functional Feeding Group Analysis

Client: Westinghouse Savannah River Company

Stream: Upper Three Runs Creek (Site 2)

County: Aiken, SC

Collection Date: 5 Nov - 8 Dec 1997

\section{TABLE . Functional Feeding Group Analysis}

Client: Westinghouse Savannah River Company

Stream: Upper Three Runs Creek (Site 2)

Courity: Aiken, SC

Collection Date: 5 Nov - 8 Dec 1997

Analysis by Number of Organisms

\begin{tabular}{|l|r|r|r|r|r|r|r|}
\hline & & & & & \\
\hline
\end{tabular}

Analysis by Biomass

\begin{tabular}{|c|c|c|c|c|c|c|c|c|}
\hline 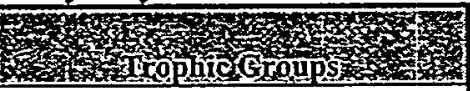 & 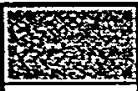 & Wy & 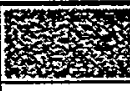 & Sy & 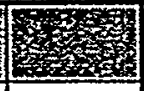 & Protalk & 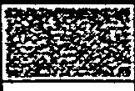 & 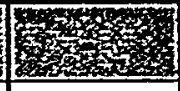 \\
\hline Collector - Gatherers & & & & & & $7.8 \%$ & & \\
\hline Collector - Filterers & & & & & & $4.9 \%$ & & \\
\hline Predators & & & & & & $54.3 \%$ & & \\
\hline Scrapers & & & & & & $6.8 \%$ & & \\
\hline Shredders & & & & & & $26.2 \%$ & & \\
\hline
\end{tabular}


Appendix Table B-5. Functional Feeding Group Analysis

Client: Westinghouse Savannah River Company

Stream: Upper Three Runs Creek (Site 3)

County: Aiken, SC

Collection Date: 5 Nov - 8 Dec 1997

Analysis by Number of Organisms

\begin{tabular}{|c|c|c|c|c|c|c|c|c|}
\hline 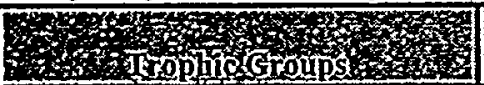 & Rep 3 & Step & Reper & RepD & 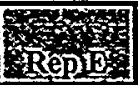 & Hotal & Neant & $\begin{array}{l}\text { \% } \\
\text { Qualitatity }\end{array}$ \\
\hline Collector - Gatherers & $10.0 \%$ & $25.0 \%$ & $13.9 \%$ & $4.5 \%$ & $7.1 \%$ & $.10 .7 \%$ & $12.1 \%$ & $18.3 \%$ \\
\hline Collector - Filterers & $20.0 \%$ & $10.0 \%$ & $33.3 \%$ & $9.1 \%$ & $50.0 \%$ & $32.7 \%$ & $24.5 \%$ & $31.7 \%$ \\
\hline Predators & $30.0 \%$ & $10.0 \%$ & $5.6 \%$ & $36.4 \%$ & $11.4 \%$ & $15.5 \%$ & $18.7 \%$ & $26.0 \%$ \\
\hline Scrapers & $10.0 \%$ & $5.0 \%$ & $11.1 \%$ & $4.5 \%$ & $1.4 \%$ & $5.4 \%$ & $6.4 \%$ & $4.3 \%$ \\
\hline Shredders & $30.0 \%$ & $50.0 \%$ & $36.1 \%$ & $45.5 \%$ & $30.0 \%$ & $35.7 \%$ & $38.3 \%$ & $21.2 \%$ \\
\hline
\end{tabular}

\begin{tabular}{|c|c|c|c|c|c|c|c|c|}
\hline 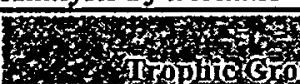 & y. & 8 & Fitis & $\left(E^{2}+4\right.$ & Sy & alotaly & W & 6ys \\
\hline Collector - Gatherers & & & & & & $0.3 \%$ & & \\
\hline Collector - Filterers & & & & & & $3.3 \%$ & & \\
\hline Predators & & & & & & $94.5 \%$ & & \\
\hline Scrapers & & & & & & $1.6 \%$ & & \\
\hline Shredders & & & & & & $0.3 \%$ & & \\
\hline
\end{tabular}




\section{Appendix Table B-5. Functional Feeding Group Analysis}

\section{Client: Westinghouse Savannah River Company}

Stream: Mill Creek (Site 4)

County: Barnwell, SC

Collection Date: 5 Nov - 8 Dec 1997

Analysis by Number of Organisms

\begin{tabular}{|c|c|c|c|c|c|c|c|c|}
\hline 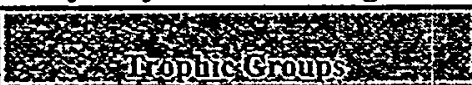 & 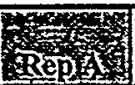 & RepiB: & Repcos & RepDI & $\mathrm{ARepi \textrm {E } ^ { 2 }}$ & wotal & niean & Qualitas \\
\hline Collector - Gatherers & $47.5 \%$ & $34.2 \%$ & $22.7 \%$ & $37.5 \%$ & $41.7 \%$ & $.36 .6 \%$ & $36.7 \%$ & $28.1 \%$ \\
\hline Collector - Filterers & $0.0 \%$ & $0.0 \%$ & $0.0 \%$ & $0.0 \%$ & $0.0 \%$ & $0.0 \%$ & $0.0 \%$ & $6.7 \%$ \\
\hline Predators & $10.0 \%$ & $5.3 \%$ & $22.7 \%$ & $12.5 \%$ & $12.5 \%$ & $12.9 \%$ & $12.6 \%$ & $25.8 \%$ \\
\hline Scrapers & $30.0 \%$ & $21.1 \%$ & $22.7 \%$ & $37.5 \%$ & $29.2 \%$ & $28.2 \%$ & $28.1 \%$ & $15.7 \%$ \\
\hline Shredders & $15.0 \%$ & $39.5 \%$ & $36.4 \%$ & $12.5 \%$ & $16.7 \%$ & $24.3 \%$ & $24.0 \%$ & $23.6 \%$ \\
\hline
\end{tabular}

\begin{tabular}{|c|c|c|c|c|c|c|c|c|}
\hline W & Pos & $x^{2}+2$ & Wy & W & Fis & 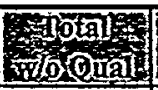 & (3) & 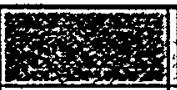 \\
\hline Collector - Gatherers & & & & & & $22.6 \%$ & & \\
\hline Collector - Filterers & & & & & & $<0.1 \%$ & & \\
\hline Predators & & & & & & $50.8 \%$ & & \\
\hline Scrapers & & & & & & $22.6 \%$ & & \\
\hline Shredders & & & & & & $4.1 \%$ & & \\
\hline
\end{tabular}


Appendix Table B-5. Functional Feeding Group Analysis

Client: Westinghouse Savannah River Company

Stream: McQueen Branch (Site 5)

County: Aiken, SC

Collection Date: 5 Nov - 8 Dec 1997

Analysis by Number of Organisms

\begin{tabular}{|c|c|c|c|c|c|c|c|c|}
\hline W & QRep & Repin & $\mathrm{Reps}$ & RepD & Rep & $\begin{array}{l}\text { Hotal } \\
\text { Hoipual }\end{array}$ & ingest & Qualitatiose \\
\hline Collector - Gatherers & $42.9 \%$ & $50.0 \%$ & $100.0 \%$ & $57.1 \%$ & $50.0 \%$ & $.52 .1 \%$ & $60.0 \%$ & $19.7 \%$ \\
\hline Collector - Filterers & $0.0 \%$ & $0.0 \%$ & $0.0 \%$ & $14.3 \%$ & $0.0 \%$ & $2.1 \%$ & $2.9 \%$ & $13.1 \%$ \\
\hline Predators & $7.1 \%$ & $15.4 \%$ & $0.0 \%$ & $0.0 \%$ & $0.0 \%$ & $6.3 \%$ & $4.5 \%$ & $22.2 \%$ \\
\hline Scrapers & $32.1 \%$ & $34.6 \%$ & $0.0 \%$ & $28.6 \%$ & $40.9 \%$ & $32.3 \%$ & $27.2 \%$ & $14.1 \%$ \\
\hline Shredders & $17.9 \%$ & $0.0 \%$ & $0.0 \%$ & $0.0 \%$ & $9.1 \%$ & $7.3 \%$ & $5.4 \%$ & $30.8 \%$ \\
\hline
\end{tabular}

Analysis by Biomass

\begin{tabular}{|c|c|c|c|c|c|c|c|c|}
\hline 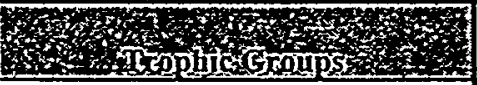 & ory & 8 & $8+3$ & os & astos & $\begin{array}{l}\text { zotal } \\
\text { uooua }\end{array}$ & 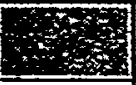 & 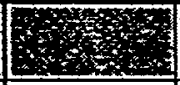 \\
\hline Collector - Gatherers & & & & & & $26.4 \%$ & & \\
\hline Collector - Filterers & & & & & & $2.0 \%$ & $\therefore$ & . \\
\hline Predators & & & & & & $42.3 \%$ & & \\
\hline Scrapers & & & & & & $26.4 \%$ & & \\
\hline Shredders & & & & & & $2.9 \%$ & & \\
\hline
\end{tabular}




\section{Appendix Table B-5. Functional Feeding Group Analysis}

Client: Westinghouse Savannah River Company

Stream: Crouch Branch (Site 6)

County: Barnwell, SC

Collection Date: 5 Nov - 8 Dec 1997

Analysis by Number of Organisms

\begin{tabular}{|c|c|c|c|c|c|c|c|c|}
\hline 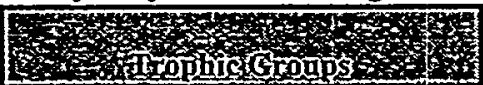 & Shepto & Sen: & Rep, $\mathrm{C}^{2}$ & SepD & Repinat & stotain & vian & Qualitat \\
\hline Collector - Gatherers & $0.0 \%$ & $0.0 \%$ & $0.0 \%$ & $50.0 \%$ & $30.0 \%$ & $.25 .0 \%$ & $16.0 \%$ & $40.0 \%$ \\
\hline Collector - Filterers & $0.0 \%$ & $0.0 \%$ & $0.0 \%$ & $0.0 \%$ & $0.0 \%$ & $0.0 \%$ & $0.0 \%$ & $0.0 \%$ \\
\hline Predators & $100.0 \%$ & $0.0 \%$ & $100.0 \%$ & $0.0 \%$ & $20.0 \%$ & $37.5 \%$ & $44.0 \%$ & $0.0 \%$ \\
\hline Scrapers & $0.0 \%$ & $0.0 \%$ & $0.0 \%$ & $0.0 \%$ & $0.0 \%$ & $0.0 \%$ & $0.0 \%$ & $0.0 \%$ \\
\hline Shredders & $0.0 \%$ & $0.0 \%$ & $0.0 \%$ & $50.0 \%$ & $50.0 \%$ & $37.5 \%$ & $20.0 \%$ & $60.0 \%$ \\
\hline
\end{tabular}

Analysis by Biomass

\begin{tabular}{|c|c|c|c|c|c|c|c|c|}
\hline 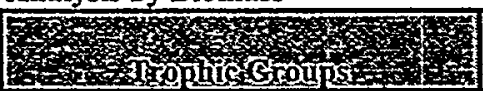 & 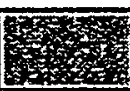 & 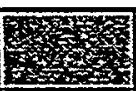 & Stris & tox & 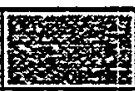 & sTotal & How & 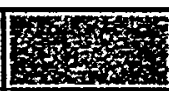 \\
\hline Collector - Gatherers & & & & & & $<0.1 \%$ & & \\
\hline Collector - Filterers & & & & & & $<0.1 \%$ & & \\
\hline Predators & & & & & & $100.0 \%$ & & \\
\hline Scrapers & & & & & & $<0.1 \%$ & & \\
\hline Shredders & & & & & & $<0.1 \%$ & & \\
\hline
\end{tabular}




\section{Appendix Table B-5. Functional Feeding Group Analysis}

Client: Westinghouse Savannah River Company

Stream: Four Mile Branch (Site 7)

County: Barnwell, SC

Collection Date: 5 Nov - 8 Dec 1997

Analysis by Number of Organisms

\begin{tabular}{|c|c|c|c|c|c|c|c|c|}
\hline (1) & Rep & Rep & Replg & 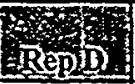 & $\begin{array}{l}38+4 \\
\text { Repio }\end{array}$ & Wotal & 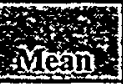 & oralitative \\
\hline Collector - Gatherers & $0.0 \%$ & $0.0 \%$ & $0.0 \%$ & $66.7 \%$ & $0.0 \%$ & $.40 .0 \%$ & $13.3 \%$ & $21.9 \%$ \\
\hline Collector - Filterers & $0.0 \%$ & $0.0 \%$ & $0.0 \%$ & $33.3 \%$ & $0.0 \%$ & $20.0 \%$ & $6.7 \%$ & $9.4 \%$ \\
\hline Predators & $0.0 \%$ & $0.0 \%$ & $0.0 \%$ & $0.0 \%$ & $100.0 \%$ & $20.0 \%$ & $20.0 \%$ & $40.6 \%$ \\
\hline Scrapers & $0.0 \%$ & $100.0 \%$ & $0.0 \%$ & $0.0 \%$ & $0.0 \%$ & $20.0 \%$ & $20.0 \%$ & $3.1 \%$ \\
\hline Shredders & $0.0 \%$ & $0.0 \%$ & $0.0 \%$ & $0.0 \%$ & $0.0 \%$ & $0.0 \%$ & $0.0 \%$ & $25.0 \%$ \\
\hline
\end{tabular}

Analysis by Biomass

\begin{tabular}{|c|c|c|c|c|c|c|c|c|}
\hline 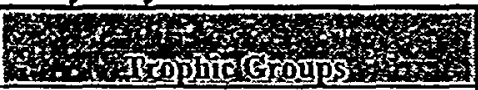 & 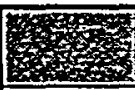 & W & \% & 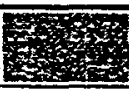 & 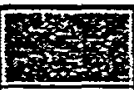 & 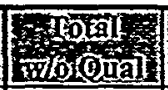 & tos & Fing \\
\hline Collector - Gatherers & & & & & & $<.1 \%$ & & \\
\hline Collector - Filterers & & & & & & $<0.1 \%$ & & \\
\hline Predators & & & & & & $100.0 \%$ & & $\therefore$ \\
\hline Scrapers & & & & & & $<0.1 \%$ & & \\
\hline Shredders & & & & & & $\infty 0.1 \%$ & & \\
\hline
\end{tabular}




\section{Appendix Table B-5. Functional Feeding Group Analysis}

Client: Westinghouse Savannah River Company

Stream: Four Mile Branch (Site 8)

County: Barnwell, SC

Collection Date: 5 Nov - 8 Dec 1997

Analysis by Number of Organisms

\begin{tabular}{|c|c|c|c|c|c|c|c|c|}
\hline 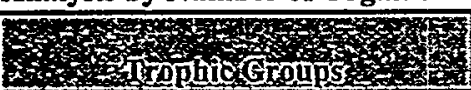 & 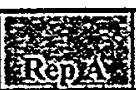 & Pép & Rap & Sepin & 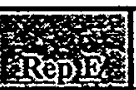 & 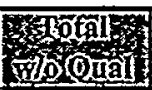 & anding & Qualitaty \\
\hline Collector - Gatherers & $60.0 \%$ & $25.0 \%$ & $33.3 \%$ & $0.0 \%$ & $0.0 \%$ & $28.1 \%$ & $23.7 \%$ & $6.7 \%$ \\
\hline Collector - Filterers & $0.0 \%$ & $50.0 \%$ & $33.3 \%$ & $80.0 \%$ & $0.0 \%$ & $37.5 \%$ & $32.7 \%$ & $6.7 \%$ \\
\hline Predators & $20.0 \%$ & $0.0 \%$ & $0.0 \%$ & $20.0 \%$ & $100.0 \%$ & $18.8 \%$ & $28.0 \%$ & $40.0 \%$ \\
\hline Scrapers & $10.0 \%$ & $0.0 \%$ & $0.0 \%$ & $0.0 \%$ & $0.0 \%$ & $3.1 \%$ & $2.0 \%$ & $13.3 \%$ \\
\hline Shredders & $10.0 \%$ & $25.0 \%$ & $33.3 \%$ & $0.0 \%$ & $0.0 \%$ & $12.5 \%$ & $13.7 \%$ & $33.3 \%$ \\
\hline
\end{tabular}

\begin{tabular}{|c|c|c|c|c|c|c|c|c|}
\hline Sy & 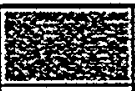 & 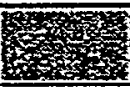 & 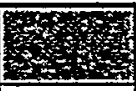 & 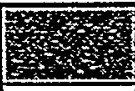 & sis & 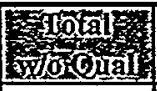 & 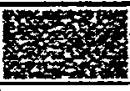 & 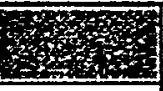 \\
\hline Collector - Gatherers & & & & & & $9.3 \%$ & & \\
\hline Collector - Filterers & & & & & & $<0.1 \%$ & & \\
\hline Predators & & & & & & $81.5 \%$ & & \\
\hline Scrapers & & & & & & $9.3 \%$ & & \\
\hline Shredders & & & & & & $<0.1 \%$ & & \\
\hline
\end{tabular}




\section{Appendix Table B-5. Functional Feeding Group Analysis}

Client: Westinghouse Savannah River Company

Stream: Four Mile Branch (Site 9)

County: Barnwell, SC

Collection Date: 5 Nov - 8 Dec 1997

Analysis by Number of Organisms

\begin{tabular}{|c|c|c|c|c|c|c|c|c|}
\hline 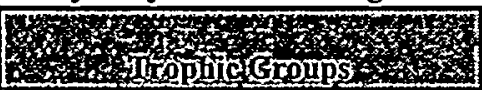 & Reps & $\mathrm{RepB}$ & $\mathrm{Rep}$ & RepiD & $\operatorname{Rep}$ & wotal & -1 ing & $\begin{array}{l}\text { ats } \\
\text { eualitative }\end{array}$ \\
\hline Collector - Gatherers & $6.6 \%$ & $7.5 \%$ & $7.6 \%$ & $21.3 \%$ & $15.3 \%$ & $.11 .1 \%$ & $11.7 \%$ & $21.1 \%$ \\
\hline Collector - Filterers & $84.9 \%$ & $79.5 \%$ & $83.3 \%$ & $55.3 \%$ & $66.1 \%$ & $74.9 \%$ & $73.8 \%$ & $19.3 \%$ \\
\hline Predators & $0.0 \%$ & $1.4 \%$ & $0.0 \%$ & $0.0 \%$ & $3.2 \%$ & $1.0 \%$ & $0.9 \%$ & $5.5 \%$ \\
\hline Scrapers & $6.6 \%$ & $4.8 \%$ & $6.9 \%$ & $17.0 \%$ & $5.6 \%$ & $7.7 \%$ & $8.2 \%$ & $36.7 \%$ \\
\hline Shredders & $1.9 \%$ & $6.8 \%$ & $2.1 \%$ & $6.4 \%$ & $9.7 \%$ & $5.4 \%$ & $5.4 \%$ & $17.4 \%$ \\
\hline
\end{tabular}

Analysis by Biomass

\begin{tabular}{|c|c|c|c|c|c|c|c|c|}
\hline 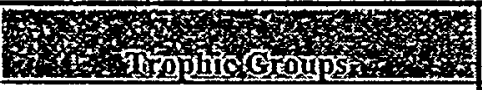 & 40 & 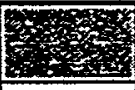 & Fis. & 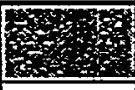 & 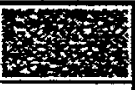 & Hotata & 28 & ond \\
\hline Collector - Gatherers & & & - & & & $7.4 \%$ & & \\
\hline Collector - Filterers & & & & & & $63.1 \%$ & & \\
\hline Predators & & & & & & $15.9 \%$ & & \\
\hline Scrapers & & & & & & $11.7 \%$ & & \\
\hline Shredders & & & & & & $1.9 \%$ & & \\
\hline
\end{tabular}




\section{Appendix Table B-5. Functional Feeding Group Analysis}

\section{Client: Westinghouse Savannah River Company}

Stream: Pen Branch (Site 10)

County: Barnwell, SC

Collection Date: 5 Nov - 8 Dec 1997

Analysis by Number of Organisms

\begin{tabular}{|c|c|c|c|c|c|c|c|c|}
\hline W & Rep & 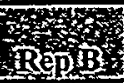 & Sepic & Replo & 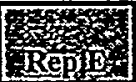 & Wrofák & ainean & Qualitatioe \\
\hline Collector - Gatherers & $43.2 \%$ & $41.7 \%$ & $32.1 \%$ & $45.0 \%$ & $45.3 \%$ & $.42 .4 \%$ & $41.5 \%$ & $36.7 \%$ \\
\hline Collector - Filterers & $0.0 \%$ & $4.2 \%$ & $0.0 \%$ & $0.0 \%$ & $0.0 \%$ & $0.9 \%$ & $0.8 \%$ & $3.9 \%$ \\
\hline Predators & $4.5 \%$ & $4.2 \%$ & $0.0 \%$ & $5.0 \%$ & $3.1 \%$ & $3.6 \%$ & $3.4 \%$ & $14.9 \%$ \\
\hline Scrapers & $40.9 \%$ & $22.9 \%$ & $28.6 \%$ & $27.5 \%$ & $29.7 \%$ & $29.9 \%$ & $29.9 \%$ & $9.1 \%$ \\
\hline Shredders & $11.4 \%$ & $27.1 \%$ & $39.3 \%$ & $22.5 \%$ & $21.9 \%$ & $23.2 \%$ & $24.4 \%$ & $35.4 \%$ \\
\hline
\end{tabular}

\begin{tabular}{|c|c|c|c|c|c|c|c|c|}
\hline 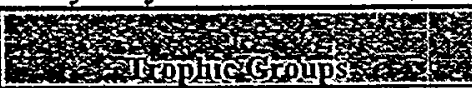 & Sy & 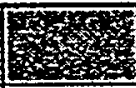 & 8 & Sting & 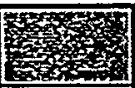 & 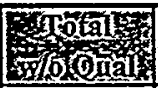 & 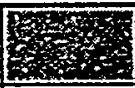 & 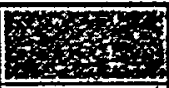 \\
\hline Collector - Gatherers & & & & & & $39.2 \%$ & & \\
\hline Collector - Filterers & & & & & & $1.4 \%$ & & \\
\hline Predators & & & & & & $14.6 \%$ & & \\
\hline Scrapers & & & & & & $37.8 \%$ & & \\
\hline Shredders & & & & & & $7.0 \%$ & & \\
\hline
\end{tabular}




\section{Appendix Table B-5. Functional Feeding Group Analysis}

Client: Westinghouse Savannah River Company

Stream: Pen Branch (Site 11)

County: Barnwell, SC

Collection Date: 5 Nov - 8 Dec 1997

Analysis by Number of Organisms

\begin{tabular}{|c|c|c|c|c|c|c|c|c|}
\hline 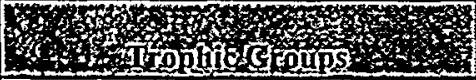 & Repis: & Rep & KReps & 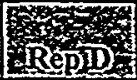 & Rep & Frotal & viean & Qunalitat \\
\hline Collector - Gatherers & $46.4 \%$ & $46.7 \%$ & $38.5 \%$ & $29.9 \%$ & $30.0 \%$ & $.36 .4 \%$ & $38.3 \%$ & $29.4 \%$ \\
\hline Collector - Filterers & $0.0 \%$ & $3.3 \%$ & $0.0 \%$ & $29.9 \%$ & $10.0 \%$ & $15.0 \%$ & $8.6 \%$ & $16.3 \%$ \\
\hline Predators & $0.0 \%$ & $6.7 \%$ & $7.7 \%$ & $4.5 \%$ & $10.0 \%$ & $5.4 \%$ & $5.8 \%$ & $22.5 \%$ \\
\hline Scrapers & $46.4 \%$ & $25.0 \%$ & $34.6 \%$ & $14.2 \%$ & $15.0 \%$ & $23.1 \%$ & $27.0 \%$ & $8.8 \%$ \\
\hline Shredders & $7.1 \%$ & $18.3 \%$ & $19.2 \%$ & $21.6 \%$ & $35.0 \%$ & $20.1 \%$ & $20.3 \%$ & $23.1 \%$ \\
\hline
\end{tabular}

Analysis by Biomass

\begin{tabular}{|c|c|c|c|c|c|c|c|}
\hline 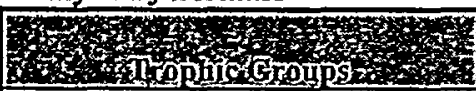 & W & $x^{4}$ & 登 & S & 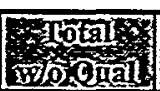 & 列 & 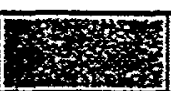 \\
\hline Collector - Gatherers & & & & & $<0.1 \%$ & & \\
\hline Collector - Filterers & & & & & $50.5 \%$ & & \\
\hline Predators & & & & & $0.9 \%$ & & \\
\hline Scrapers & & & & & $39.1 \%$ & & \\
\hline Shredders & & & & & $9.5 \%$ & & \\
\hline
\end{tabular}




\section{Appendix Table B-5. Functional Feeding Group Analysis}

Client: Westinghouse Savannah River Company

Stream: Indian Grave Branch (Site 12)

County: Barnwell, SC

Collection Date: 5 Nov - 8 Dec 1997

\begin{tabular}{|c|c|c|c|c|c|c|c|c|}
\hline 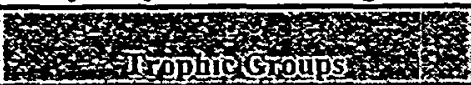 & Reps & Sep & Repd & $\begin{array}{l}\mathrm{Asc} \\
\mathrm{RepD}\end{array}$ & Reping & 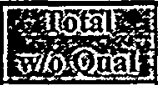 & Nean & Oualitates \\
\hline Collector - Gatherers & $44.4 \%$ & $43.3 \%$ & $51.3 \%$ & $39.3 \%$ & $42.9 \%$ & $46.2 \%$ & $44.2 \%$ & $42.9 \%$ \\
\hline Collector - Filterers & $0.0 \%$ & $0.0 \%$ & $2.6 \%$ & $7.1 \%$ & $7.1 \%$ & $3.3 \%$ & $3.4 \%$ & $11.5 \%$ \\
\hline Predators & $11.1 \%$ & $13.3 \%$ & $10.3 \%$ & $14.3 \%$ & $14.3 \%$ & $12.1 \%$ & $12.7 \%$ & $3.8 \%$ \\
\hline Scrapers & $22.2 \%$ & $3.3 \%$ & $16.7 \%$ & $14.3 \%$ & $25.0 \%$ & $16.5 \%$ & $16.3 \%$ & $10.9 \%$ \\
\hline Shredders & $22.2 \%$ & $40.0 \%$ & $19.2 \%$ & $25.0 \%$ & $10.7 \%$ & $22.5 \%$ & $23.4 \%$ & $30.8 \%$ \\
\hline
\end{tabular}

Analysis by Biomass

\begin{tabular}{|c|c|c|c|c|c|c|c|c|}
\hline 6) & mos & W & W & 8 & Sty & ototal & $x^{2}+2$ & 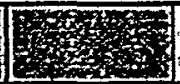 \\
\hline Collector - Gatherers & & & & & & $87.0 \%$ & & \\
\hline Collector - Filterers & & & & & & $1.1 \%$ & & \\
\hline Predators & & & & & & $2.6 \%$ & & \\
\hline Scrapers & & & & & & $9.3 \%$ & & \\
\hline Shredders & & & & & & $<0.1 \%$ & & \\
\hline
\end{tabular}




\section{Appendix Table B-5. Functional Feeding Group Analysis}

\section{Client: Westinghouse Savannah River Company}

Stream: Pen Branch (Site 13)

County: Barnwell, SC

Collection Date: 5 Nov - 8 Dec 1997

Analysis by Number of Organisms

\begin{tabular}{|c|c|c|c|c|c|c|c|c|}
\hline 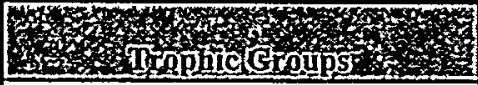 & Repry & $2 \mathrm{RepB}$ & RepL & RepD & ERepin & $\begin{array}{l}\text { Wotal } \\
\text { wougal }\end{array}$ & Nuants & oulititat \\
\hline Collector - Gatherers & $0.0 \%$ & $25.0 \%$ & $48.7 \%$ & $41.1 \%$ & $40.0 \%$ & $.40 .7 \%$ & $31.0 \%$ & $34.3 \%$ \\
\hline Collector - Filterers & $0.0 \%$ & $20.0 \%$ & $25.6 \%$ & $21.4 \%$ & $0.0 \%$ & $20.9 \%$ & $13.4 \%$ & $25.9 \%$ \\
\hline Predators & $25.0 \%$ & $20.0 \%$ & $2.6 \%$ & $3.6 \%$ & $40.0 \%$ & $8.1 \%$ & $18.2 \%$ & $8.3 \%$ \\
\hline Scrapers & $0.0 \%$ & $25.0 \%$ & $0.0 \%$ & $12.5 \%$ & $20.0 \%$ & $8.1 \%$ & $11.5 \%$ & $9.3 \%$ \\
\hline Shredders & $75.0 \%$ & $10.0 \%$ & $23.1 \%$ & $21.4 \%$ & $0.0 \%$ & $22.1 \%$ & $25.9 \%$ & $22.2 \%$ \\
\hline
\end{tabular}

Analysis by Biomass

\begin{tabular}{|c|c|c|c|c|c|c|c|c|}
\hline 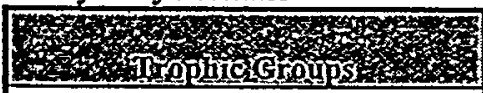 & \% & 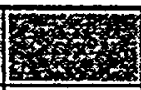 & (1) & 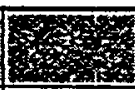 & 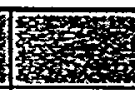 & 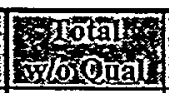 & as & 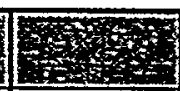 \\
\hline Collector - Gatherers & & & & & & $3.3 \%$ & & \\
\hline Collector - Filterers & & & & & & $0.9 \%$ & & \\
\hline Predators & & & & & & $93.0 \%$ & & \\
\hline Scrapers & & & & & & $2.3 \%$ & & \\
\hline Shredders & & & & & & $0.5 \%$ & & \\
\hline
\end{tabular}




\section{Appendix Table B-5. Functional Feeding Group Analysis}

\section{Client: Westinghouse Savannah River Company}

Stream: Steel Creek (Site 14)

County: Barnwell, SC

Collection Date: 5 Nov - 8 Dec 1997

Analysis by Number of Organisms

\begin{tabular}{|c|c|c|c|c|c|c|c|c|}
\hline 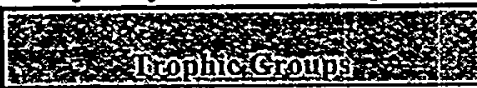 & Shepay & Retis & ReplC & Bopis & Fep & 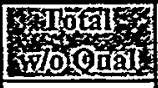 & inf & Quilitative \\
\hline Collector - Gatherers & $0.0 \%$ & $40.0 \%$ & $61.1 \%$ & $20.0 \%$ & $29.5 \%$ & $.34 .4 \%$ & $30.1 \%$ & $18.0 \%$ \\
\hline Collector - Fil & $0.0 \%$ & $0.0 \%$ & $0.0 \%$ & $0.0 \%$ & $7.7 \%$ & $4.7 \%$ & $1.5 \%$ & $18.0 \%$ \\
\hline Predators & $100.0 \%$ & $10.0 \%$ & $11.1 \%$ & $40.0 \%$ & $2.6 \%$ & $9.4 \%$ & $32.7 \%$ & $43.0 \%$ \\
\hline Scrapers & $0.0 \%$ & $50.0 \%$ & $16.7 \%$ & $40.0 \%$ & $12.8 \%$ & $21.1 \%$ & $23.9 \%$ & $6.5 \%$ \\
\hline Shredders & $0.0 \%$ & $0.0 \%$ & $11.1 \%$ & $0.0 \%$ & $47.4 \%$ & $30.5 \%$ & $11.7 \%$ & $14.5 \%$ \\
\hline
\end{tabular}

Analysis by Biomass

\begin{tabular}{|c|c|c|c|c|c|c|c|c|}
\hline 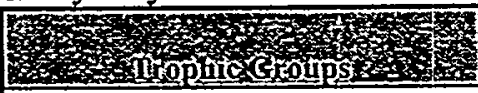 & 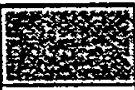 & S & 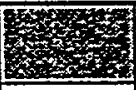 & 3ris & 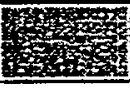 & 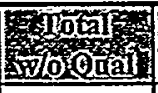 & 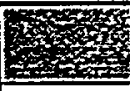 & 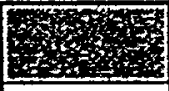 \\
\hline Collector - Gatherers & & & & & & $23.6 \%$ & & \\
\hline Collector-Filterers & & & & & & $<0.1 \%$ & & \\
\hline Predators & & & & & & $46.3 \%$ & & \\
\hline Scrapers & & & & & & $23.6 \%$ & & \\
\hline Shredders & & & & & & $6.5 \%$ & & \\
\hline
\end{tabular}




\title{
Appendix Table B-5. Functional Feeding Group Analysis
}

\author{
Client: Westinghouse Savannah River Company \\ Stream: Meyers Branch (Site 15) \\ County: Barnwell, SC \\ Collection Date: 5 Nov - 8 Dec 1997
}

Analysis by Number of Organisms

\begin{tabular}{|c|c|c|c|c|c|c|c|c|}
\hline 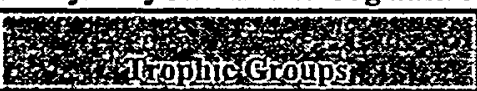 & Bep 4 & Repis & Repice & 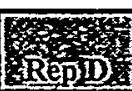 & Rep & $\begin{array}{l}\text { Total } \\
\text { voloroual }\end{array}$ & inean & Qualizts \\
\hline Collector - Gatherers & $41.7 \%$ & $35.4 \%$ & $59.6 \%$ & $58.8 \%$ & $46.3 \%$ & $.49 .4 \%$ & $48.3 \%$ & $32.5 \%$ \\
\hline Collector - Filterers & $22.2 \%$ & $8.3 \%$ & $3.8 \%$ & $7.5 \%$ & $27.8 \%$ & $15.4 \%$ & $13.9 \%$ & $16.5 \%$ \\
\hline Predators & $16.7 \%$ & $20.8 \%$ & $3.8 \%$ & $2.5 \%$ & $0.0 \%$ & $6.2 \%$ & $8.8 \%$ & $10.3 \%$ \\
\hline Scrapers & $13.9 \%$ & $6.3 \%$ & $7.7 \%$ & $6.3 \%$ & $4.6 \%$ & $6.8 \%$ & $7.7 \%$ & $13.4 \%$ \\
\hline Shredders & $5.6 \%$ & $29.2 \%$ & $25.0 \%$ & $25.0 \%$ & $21.3 \%$ & $22.2 \%$ & $21.2 \%$ & $27.8 \%$ \\
\hline
\end{tabular}

\begin{tabular}{|c|c|c|c|c|c|c|c|c|}
\hline Analysis by Biomass & & $\cdot$ & - & & & & & \\
\hline W & 20 & 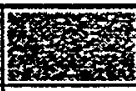 & 28 & 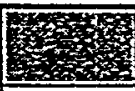 & 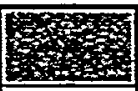 & 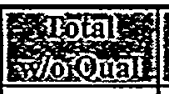 & 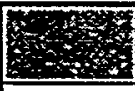 & \% \\
\hline Collector - Gatherers & & & & & & $50.7 \%$ & & \\
\hline Collector - Filterers & & & & & & $6.8 \%$ & & \\
\hline Predators & & & & & & $10.4 \%$ & & \\
\hline Scrapers & & & & & & $29.4 \%$ & & \\
\hline Shredders & & & & & & $2.7 \%$ & & \\
\hline
\end{tabular}




\section{Appendix Table B-5. Functional Feeding Group Analysis}

Client: Westinghouse Savannah River Company

Stream: Four Mile (Site 10)

County: Barnwell, SC

Collection Date: 5 Nov - 8 Dec 1997

\begin{tabular}{|c|c|c|c|c|c|c|c|c|}
\hline Sys & Rep ${ }_{2}$ & Repris & Seplat & 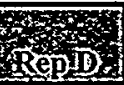 & Rep & Sológit & Mean & 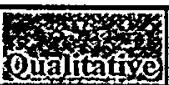 \\
\hline Collector - Gatherers & $32.4 \%$ & $74.6 \%$ & $54.9 \%$ & $38.6 \%$ & $55.3 \%$ & $58.0 \%$ & $51.2 \%$ & $44.8 \%$ \\
\hline Collector - Filterers & $23.5 \%$ & $7.2 \%$ & $24.4 \%$ & $22.7 \%$ & $31.6 \%$ & $20.4 \%$ & $21.9 \%$ & $19.8 \%$ \\
\hline Predators & $5.9 \%$ & $0.0 \%$ & $2.4 \%$ & $4.5 \%$ & $3 . \dot{5} \%$ & $2.4 \%$ & $3.3 \%$ & $9.4 \%$ \\
\hline Scrapers & $32.4 \%$ & $13.8 \%$ & $11.0 \%$ & $27.3 \%$ & $7.9 \%$ & $14.8 \%$ & $18.5 \%$ & $7.3 \%$ \\
\hline Shredders & $5.9 \%$ & $4.3 \%$ & $7.3 \%$ & $6.8 \%$ & $1.8 \%$ & $4.6 \%$ & $5.2 \%$ & $18.8 \%$ \\
\hline
\end{tabular}

\begin{tabular}{|c|c|c|c|c|c|c|c|c|}
\hline S & Whys & 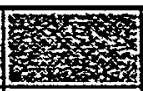 & 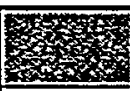 & 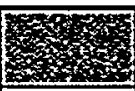 & 6 & 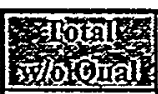 & 9x & 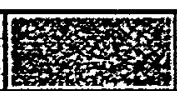 \\
\hline Collector - Gatherers & & & & & & $42.5 \%$ & & \\
\hline Collector-Filterers & & & & & & $5.4 \%$ & & \\
\hline Predators & & & & & & $7.0 \%$ & & \\
\hline Scrapers & & & & & & $45.1 \%$ & & \\
\hline Shredders & & & & & & $<0.1 \%$ & & \\
\hline
\end{tabular}


Appendix Table B-6. Summary of Biological Indices for Macroinvertebrate Data

Westinghouse Savannah River Company

Sitewide Study

5 Nov. - 8 Dec 1997

\begin{tabular}{|c|c|c|c|c|c|c|c|c|c|c|c|c|c|c|c|c|}
\hline \multirow[b]{2}{*}{ Parameter } & \multicolumn{6}{|c|}{ Upper Three Runs Creek System } & \multicolumn{4}{|c|}{ Four Mile Branch System } & \multicolumn{4}{|c|}{ Pen Branch System } & \multicolumn{2}{|c|}{ Steel Cr. System } \\
\hline & \begin{tabular}{|l|} 
Tims \\
Site 1
\end{tabular} & $\begin{array}{c}\text { Mill } \\
\text { Site } 4\end{array}$ & $\begin{array}{l}\mathrm{McQ} \\
\text { Site } 5\end{array}$ & \begin{tabular}{|c|} 
Crouch \\
Site 6 \\
\end{tabular} & $\begin{array}{r}\text { U3R } \\
\text { Site } 3\end{array}$ & $\begin{array}{c}\text { U3R } \\
\text { Site } 2 \\
\end{array}$ & $\begin{array}{l}\text { FMB } \\
\text { Site } 7 \\
\end{array}$ & $\begin{array}{l}\text { FMB } \\
\text { Site } 8 .\end{array}$ & $\begin{array}{l}\text { FMB } \\
\text { Site } 9\end{array}$ & \begin{tabular}{c|} 
FMB \\
Site 16
\end{tabular} & $\begin{array}{c}\text { Pen } \\
\text { Site } 10\end{array}$ & \begin{tabular}{|c|} 
Pen \\
Site 11 \\
\end{tabular} & \begin{tabular}{|l} 
Ind. Gr. \\
Site 12 \\
\end{tabular} & $\begin{array}{c}\text { Pen } \\
\text { Site } 13 \\
\end{array}$ & \begin{tabular}{|c|} 
Steel \\
Site 14 \\
\end{tabular} & \begin{tabular}{|l|} 
Meyers \\
Site 15 \\
\end{tabular} \\
\hline Total \# of Species & Whot & 20 & 11 & .5 & 27 & 37 & 5 & 11 & 26 & 29 & 10 & 21 & 23 & 22 & 17 & 18 \\
\hline Mean Species per Replicate & 3.4 & 4.0 & 2.2 & 1.0 & 5.4 & 7.4 & 1.0 & 2.2 & 5.2 & 5.8 & 2.0 & 4.2 & 4.6 & 4.4 & 3.4 & 3.6 \\
\hline EPT Index & 3 & 9 & 5 & 0 & 15 & 16 & 0 & 1 & 9 & 7 & 7 & 7 & 4 & 3 & 4 & 6 \\
\hline Density (organisms/m2) & 73.3 & 112 & 53.3 & 8.9 & 93.3 & 232 & 5.6 & 17.8 & 341 & 229 & 124 & 163 & 101 & 95.6 & 71.1 & 180 \\
\hline Total Biomass (g) & 1.0685 & 0.0518 & 0.0317 & 0.0006 & 0.2590 & 0.2582 & 0.0061 & 0.0054 & 0.1226 & 0.0315 & 0.0513 & 0.0654 & 0.0702 & 0.1356 & 0.0428 & 0.0221 \\
\hline Biotic Index & 6.72 & 4.87 & 5.18 & 8.88 & 3.70 & 4.84 & 8.15 & 7.15 & 6.40 & 5.95 & 5.51 & 5.16 & 6.58 & 6.54 & 5.81 & 4.81 \\
\hline
\end{tabular}

$\underset{1}{\infty}$ 
Appendix Table B-6. Summary of Biological Indices for Macroinvertebrate Data

Westinghouse Savannah River Company

Sitewide Study

5 Nov. - 8 Dec 1997

\begin{tabular}{|c|c|c|c|c|c|c|c|c|c|c|c|c|c|c|c|c|}
\hline \multirow[b]{2}{*}{ Parameter } & \multicolumn{6}{|c|}{ Upper Three Runs Creek System } & \multicolumn{4}{|c|}{ Four Mile Branch System } & \multicolumn{4}{|c|}{ Pen Branch System } & \multicolumn{2}{|c|}{ Steel Cr. System } \\
\hline & $\begin{array}{l}\text { Tims } \\
\text { Site } 1 \\
\end{array}$ & $\begin{array}{c}\text { Mill } \\
\text { Site } 4 \\
\end{array}$ & $\begin{array}{l}\text { McQ } \\
\text { Site } 5 \\
\end{array}$ & \begin{tabular}{|c|} 
Crouch \\
Site 6 \\
\end{tabular} & $\begin{array}{c}\text { U3R } \\
\text { Site } 3 \\
\end{array}$ & $\begin{array}{c}\text { U3R } \\
\text { Site 2 } \\
\end{array}$ & $\begin{array}{l}\text { FMB } \\
\text { Site 7 } \\
\end{array}$ & $\begin{array}{l}\text { FMB } \\
\text { Site } 8 \\
\end{array}$ & $\begin{array}{l}\text { FMB } \\
\text { Site 9 } \\
\end{array}$ & $\begin{array}{c}\text { FMB } \\
\text { Site 16 } \\
\end{array}$ & \begin{tabular}{|c|} 
Pen \\
Site 10 \\
\end{tabular} & \begin{tabular}{|c|} 
Pen \\
Site 11 \\
\end{tabular} & $\begin{array}{l}\text { Ind. Gr. } \\
\text { Site } 12 \\
\end{array}$ & \begin{tabular}{|c|} 
Pen \\
Site 13 \\
\end{tabular} & \begin{tabular}{|c|} 
Steel \\
Site 14 \\
\end{tabular} & \begin{tabular}{|l} 
Meyers \\
Site 15 \\
\end{tabular} \\
\hline Total \# of Species (Qualitative) & Pin & 39 & 33 & 3 & 41 & 61 & 15 & 11 & 20 & 27 & 34 & 34 & 25 & 30 & 33 & 40 \\
\hline Total \# of Species (Qual. \& Quant.) & 41 & 50 & 38 & 8 & 51 & 81 & 18 & 19 & 36 & 41 & 38 & 44 & 38 & 45 & 41 & 47 \\
\hline EPT Index & 3 & 9 & 12 & 0 & 18 & 20 & 0 & 1 & 6 & 6 & 9 & 7 & 7 & 7 & 6 & 17 \\
\hline Biotic Index & 6.37 & 5.62 & 5.39 & 7.60 & 4.76 & 4.45 & 7.47 & 6.63 & 6.56 & 5.95 & 6.10 & 6.07 & 7.05 & 6.82 & 6.77 & 5.68 \\
\hline
\end{tabular}

Wr
1
N 


\section{Appendix Table B-7. Biological Parameter Results and Water Quality Ratings}

Client: Westinghouse Savannah River Company

Stréam: Tims Branch (Site 1)

County: Barnwell, SC

Collection Date: 5 Nov - 8 Dec 1997

\begin{tabular}{|c|c|c|c|c|c|c|c|c|c|}
\hline 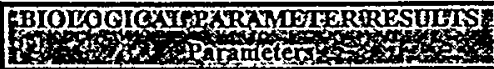 & $3 x$ & $8 \mathrm{RCDB}$ & $\mathrm{R}_{\mathrm{R}, \mathrm{C}}$ & heps: & - & Fon & $\sin$ & Qnaliative & Groplas \\
\hline 1. Taxa Richness & 6 & $\overline{6}$ & 4 & 8 & 4 & 17 & 3.4 & 33 & 41 \\
\hline (Total Number of Organisms / Site) & -6) & 19 & 19 & 15 & 7 & 66 & 13.2 & 128 & 194 \\
\hline 2. EPT Index & 1.0 & 1.0 & 0.0 & 1.0 & 1.0 & NA & 0.8 & 3.0 & $\mathbf{N A}$ \\
\hline 3. EPT / Chironomid Ratio & 0.5 & 0.4 & 0.0 & 0.1538462 & I & NA & 0.4 & 0.1 & NA \\
\hline 4. Scraper / Filterer Ratio & 0.00 & 0.00 & 0.00 & 0.00 & 0.10 & $\underline{\mathbf{N A}}$ & 0.02 & 0.02 & NA \\
\hline 5. Biotic Index & 6.82 & 5.93 & 8.57 & 7.56 & 4.73 & NA & 6.72 & 6.37 & NA \\
\hline 6.\% Dominant Taxon & $17 \%$ & $42 \%$ & $84 \%$ & $33 \%$ & $57 \%$ & NA & $47 \%$ & $23 \%$ & NA \\
\hline 7. Shredder / Total \# of Organisms Ratio & 0.00 & 0.03 & 0.03 & 0.07 & 0.14 & $\mathbf{N A}$ & 0.05 & 0.08 & NA \\
\hline 8. Density (organisms/m2) & 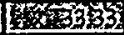 & 105.56 & 105.56 & 83.33 & 38.89 & 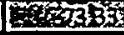 & 73.33 & DSA & NA \\
\hline
\end{tabular}




\section{Appendix Table B-7. Biological Parameter Results and Water Quality Ratings}

Client: Westinghouse Savannah River Company

Stream: Upper Three Runs Creek (Site 2)

County: Aiken, SC

Collection Date: 5 Nov - 8 Dec 1997

\begin{tabular}{|c|c|c|c|c|c|c|c|c|c|}
\hline 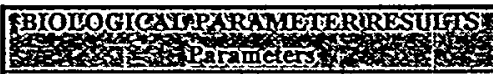 & SRep & Kensing & Repas & Kepting & 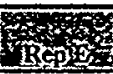 & Stoon & \% & Oratititive & 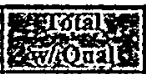 \\
\hline 1. Taxa Richness & 16 & 17 & 24 & 11 & $\overline{4}$ & 37 & 7.4 & 61 & 81 \\
\hline (Total Number of Organisms / Site) & 37 & 36 & 99 & 31 & $\overline{6}$ & 209 & 41.8 & 255 & 464 \\
\hline 2. EPT Index & 11.0 & 6.0 & 11.0 & $\mathbf{5 . 0}$ & 20 & NA & $\overline{7.0}$ & 20.0 & NA \\
\hline 3. EPT / Chironomid Ratio & 3.0 & 0.7 & 0.3 & 7 & $\overline{1}$ & NA & 1.2 & 1.5 & NA \\
\hline 4. Scraper / Filterer Ratio & 0.64 & 1.50 & 0.33 & 0.25 & 0.00 & NA & 0.55 & 0.26 & NA \\
\hline 5. Biotic Index & 3.94 & 5.61 & 5.78 & 4.28 & 4.57 & NA & 4.84 & 4.45 & NA \\
\hline 6.\% Dominant Taxon & $30 \%$ & $28 \%$ & $40 \%$ & $23 \%$ & $33 \%$ & NA & $31 \%$ & $16 \%$ & NA \\
\hline 7. Shredder/ Total \# of Onganisms Ratio & 0.34 & 0.25 & 0.32 & 0.34 & 0.67 & NA & 0.38 & 0.21 & NA \\
\hline 8. Density (organisms/m2) & \% 030 & 200.00 & 550.00 & 172.22 & 33.33 & 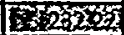 & 232.22 & $\mathrm{MA}$ & $\overline{\mathbf{N}}$ \\
\hline
\end{tabular}




\section{Appendix Table B-7. Biological Parameter Results and Water Quality Ratings}

Client: Westinghouse Savannah River Company

Stream: Upper Three Runs Creck (Site 3)

County: Aiken, SC

Collection Date: 5 Nov - 8 Dec 1997

\begin{tabular}{|c|c|c|c|c|c|c|c|c|c|}
\hline 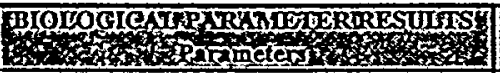 & 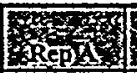 & ERE & Steps & Rep & Repis & Foorat & Sutin & \begin{tabular}{r|} 
\\
Quglitative
\end{tabular} & 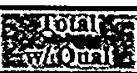 \\
\hline 1. Taxa Richness & 8 & 7 & 10 & 5 & 18 & 27 & 5.4 & 41 & 51 \\
\hline (Total Number of Organisms / Site) & 10 & 10 & 18 & II & 35 & 84 & 16.8 & 104 & 188 \\
\hline 2. EPT Index & 6.0 & 2.0 & 5.0 & 5.0 & 12.0 & NA & 6.0 & 18.0 & $\mathbf{N A}$ \\
\hline 3. EPT/ Chironomid Ratio & 3.5 & 1.3 & 1.8 & NA & 8.7 & NA & 3.0 & 2.6 & NA \\
\hline 4. Scraper / Filterer Ratio & 0.50 & 0.50 & 0.33 & 0.50 & 0.03 & NA & 0.37 & 0.14 &. $\mathbf{N A}$ \\
\hline 5. Biotic Index & 4.26 & 4.04 & 4.63 & 247 & 3.10 & NA & 3.70 & 4.76 & $\overline{\mathbf{N A}}$ \\
\hline 6.\% Dominant Taxon & $20 \%$ & $40 \%$ & $22 \%$ & $36 \%$ & $17 \%$ & NA & $27 \%$ & $9 \%$ & NA \\
\hline 7. Shredder / Total \# of Organisms Ratio & 0.30 & 0.50 & 0.36 & 0.45 & 0.30 & . NA & $\overline{0.38}$ & 0.21 & NA \\
\hline 8. Density (organisms/m2) & Bets5 & 55.56 & 100.00 & 61.11 & 194.44 & 2833 & 93.33 & 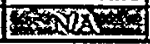 & NA \\
\hline
\end{tabular}




\section{Appendix Table B-7. Biological Parameter Results and Water Quality Ratings}

Client: Westinghouse Savannah River Company

Stream: Mill Creek (Site 4)

County: Barnwell, SC

Collection Date: 5 Nov - 8 Dec 1997

\begin{tabular}{|c|c|c|c|c|c|c|c|c|c|}
\hline 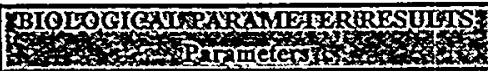 & 6ris & Kap & $\mathrm{SPO}_{\mathrm{S}}$ & SRpD & Sepros & Tóntian & 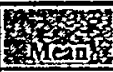 & 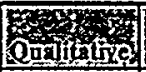 & 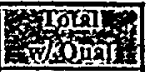 \\
\hline 1. Taxa Richness & 7 & $\overline{4}$ & 7 & 5 & 9 & 20 & 4 & 39 & 50 \\
\hline (Total Number of Organisms / Site) & 20 & 19 & 22 & 16 & 24 & 101 & 20.2 & 89 & 190 \\
\hline 2. EPT Index & 5.0 & 3.0 & 3.0 & 4.0 & 4.0 & NA & 3.8 & 9.0 & NA \\
\hline 3. EPT/Chironomid Ratio & 8.5 & 2.8 & 9.0 & NA & 4.75 & $\mathbf{N A}$ & 5.0 & 1.0 & NA \\
\hline 4. Scraper/Filterer Ratio & NA & ERR & NA & NA & $\mathrm{NA}$ & NA & ERR & 2.33 & NA \\
\hline 5. Biotic Index & 4.71 & 5.06 & 4.05 & 5.05 & 5.50 & NA & 4.87 & 5.62 & NA \\
\hline 6.\% Dominant Taxon & $55 \%$ & $42 \%$ & $36 \%$ & $75 \%$ & $58 \%$ & NA & $53 \%$ & $12 \%$ & NA \\
\hline 7. Shredder / Total \# of Organisms Ratio & 0.15 & 0.39 & 0.36 & 0.13 & 0.17 & NA & 0.24 & 0.24 & $\mathbf{N A}$ \\
\hline 8. Density (organisms/m2) & B.1610 & 105.56 & 122.22 & 88.89 & 133.33 & $8 \times 1022$ & 112.22 & 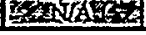 & NA \\
\hline
\end{tabular}




\section{Appendix Table B-7. Biological Parameter Results and Water Quality Ratings}

Client: Westinghouse Savannah River Company

Ştream: McQueen Branch (Site 5)

County: Aiken, SC

Collection Date: 5 Nov - 8 Dec 1997

\begin{tabular}{|c|c|c|c|c|c|c|c|c|c|}
\hline 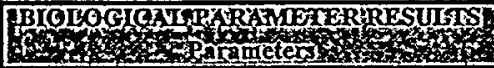 & 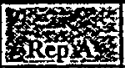 & SRepin & Repis & RepDin & 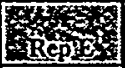 & Fotalk & 10 & Oaglitio & SThong \\
\hline 1. Taxa Richness & 5 & 5 & 2 & $\overrightarrow{4}$ & 3 & 11 & 2.2 & 33 & 38 \\
\hline (Total Number of Organisms / Site) & 14 & 13 & 3 & 7 & 11 & 48 & 9.6 & 99 & 147 \\
\hline 2. EPT Index & 3.0 & 3.0 & 1.0 & 2.0 & 3.0 & NA & 2.4 & 12.0 & NA \\
\hline 3. EPT/Chironomid Ratio & 12.0 & 11.0 & 0.5 & 2.5 & NA & $\mathbf{N} \mathbf{\lambda}$ & 5.2 & 2.6 & $\mathbf{N A}$ \\
\hline 4. Scraper/Filterer Ratio & NA & NA & $\mathbf{N A}$ & 2.00 & NA & NA & 0.40 & 1.08 & NA \\
\hline 5. Biotic Index & 5.39 & 5.58 & 3.90 & 5.64 & 5.39 & NA & 5.18 & 5.39| & $\mathrm{NA}$ \\
\hline 6. \% Dominant Taxon & $64 \%$ & $69 \%$ & $67 \%$ & $57 \%$ & $82 \%$ & NA & $68 \%$ & $11 \%$ & NA \\
\hline 7. Shredder / Total \# of Omganisms Ratio & 0.18 & 0.00 & 0.00 & 0.00 & 0.09 & NA & 0.05 & 0.31 & $\mathbf{N A}$ \\
\hline 8. Density (organisms/m2) & H经得8 & 72.22 & 16.67 & 38.89 & 61.11 & 05333 & 53.33 & KaNA & NA \\
\hline
\end{tabular}




\section{Appendix Table B-7. Biological Parameter Results and Water Quality Ratings}

Client: Westinghouse Savannah River Company

Stream: Crouch Branch (Site 6)

County: Barnwell, SC

Collection Date: 5 Nov - 8 Dec 1997

\begin{tabular}{|c|c|c|c|c|c|c|c|c|c|}
\hline 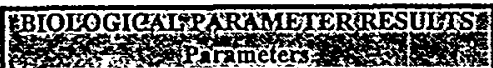 & Stping & 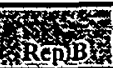 & Mescas & RepD & Saps & MTóa & ond & Qunitintry & STorata \\
\hline 1. Taxa Richness & 1 & 0 & 1 & I & 3 & 5 & 1 & 3 & $\overline{8}$ \\
\hline (Total Number of Otganisms / Site) & 1 & $\overline{0}$ & 1. & 1 & 5 & 8 & 1.6 & 5 & 13 \\
\hline 2. EPT Index & 0.0 & 0.0 & 0.0 & 0.0 & 0.0 & NA & 0.0 & 0.0 & $\overline{\text { NA }}$ \\
\hline 3. EPT/Chironomid Ratio & 0.0 & 0.0 & 0.0 & $\underline{0}$ & 0 & NA & 0.0 & 0.0 & NA \\
\hline 4. Scraper/ Filterer Ratio & NA & 0.00 & NA & NA & $\overline{\mathbf{N A}}$ & NA & 0.00 & NA & $\overline{\mathrm{NA}}$ \\
\hline 5. Biotic Index & 9.00 & 10.00 & 8.70 & 8.50 & 8.18 & NA & 8.88 & 7.60 & NA \\
\hline 6.\% Dominant Taxon & $100 \%$ & $100 \%$ & $100 \%$ & $100 \%$ & $60 \%$ & NA & $92 \%$ & $60 \%$ & NA \\
\hline 7. Shredder/ Total \# of Organisms Ratio & 0.00 & 0.00 & 0.00 & 0.50 & 0.50 & $\mathrm{NA}$ & 0.20 & 0.60 & NA \\
\hline 8. Density (onganisms/m2) & 3. & 0.00 & 5.56 & 5.56 & 27.78 & 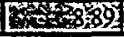 & 8.89 & BNAS & NA \\
\hline
\end{tabular}




\section{Appendix Table B-7. Biological Parameter Results and Water Quality Ratings}

Client: Westinghouse Savannah River Company

Stream: Four Mile Branch (Site 7)

County: Barnwell, SC

Collection Date: 5 Nov - 8 Dec 1997

\begin{tabular}{|c|c|c|c|c|c|c|c|c|c|}
\hline 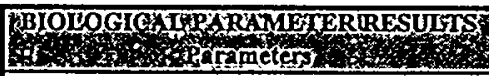 & Whos & Reris & Repas & Rep & $P$ R & Tơra & ineme & Oughtitu & Tiong \\
\hline 1. Taxa Richness & $\underline{0}$ & 1 & of & 3 & 1 & 5 & 1 & 15 & $\frac{18}{-1}$ \\
\hline (Total Number of Organisms / Site) & 0 & 1 & 0 & 3 & 1 & 5 & $\overline{1}$ & 32 & 37 \\
\hline 2. EPT Index & 0.0 & 0.0 & 0.0 & 0.0 & 0.0 & $\mathrm{NA}$ & 0.0 & 0.0 & $\overline{\mathrm{NA}}$ \\
\hline 3. EPT/Chironomid Ratio & 0.0 & 0.0 & 0.0 & 0 & 0 & NA & 0.0 & 0.0 & NA \\
\hline 4. Scraper / Fillerer Ratio & NA & NA & NA & 0.00 & NA & NA & 0.00 & 0.33 & NA \\
\hline 5. Biotic Index & 10.00 & 6.90 & 10.00 & 6.53 & 7.30 & NA & 8.15 & 7.47 & $\mathrm{NA}$ \\
\hline 6.\% Dominant Taxon & $100 \%$ & $100 \%$ & $100 \%$ & $33 \%$ & $100 \%$ & $\mathbf{N A}$ & $87 \%$ & $22 \%$ & NA \\
\hline 7. Shredder / Total \# of Organisms Ratio & 0.00 & 0.00 & 0.00 & 0.00 & 0.00 & $\mathrm{NA}$ & 0.00 & 0.25 & $\overline{N A}$ \\
\hline 8. Density (organisms/m2) & 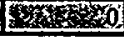 & 5.56 & 0.00 & 16.67 & 5.56 & $5 \times 556$ & 5.56 & 20 & $\overline{\mathbf{N A}}$ \\
\hline
\end{tabular}




\title{
Appendix Table B-7. Biological Parameter Results and Water Quality Ratings
}

\author{
Client: Westinghouse Savannah River Company \\ Stream: Four Mile Branch (Site 8) \\ County: Barnwell, SC \\ Collection Date: 5 Nov - 8 Dec 1997
}

\begin{tabular}{|c|c|c|c|c|c|c|c|c|c|}
\hline 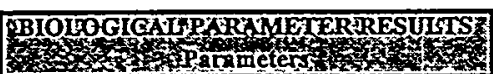 & 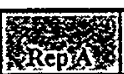 & 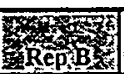 & Kep C & Gepin & SRepes & Totion & acting & Cualitatto & Trotal \\
\hline 1. Taxa Richness & 5 & 2 & 3 & 3 & 1 & 11 & 2.2 & 11 & 19 \\
\hline (Total Number of Organisms / Site) & 5 & 2 & 3 & 5 & 1 & 16 & 3.2 & 15 & 31 \\
\hline 2. EPT Index & 0.0 & 0.0 & 1.0 & 0.0 & 0.0 & NA & 0.2 & 1.0 & $\mathrm{NA}$ \\
\hline 3. EPT / Chironomid Ratio & 0.0 & 0.0 & 1.0 & 0 & $\overline{0}$ & NA & 0.2 & 0.5 & NA \\
\hline 4. Seraper / Fillerer Ratio & NA & 0.00 & 0.00 & 0.00 & NA & NA & 0.00 & 2.00 & NA \\
\hline 5. Biotic Index & 7.96 & 5.85 & 6.50 & 7.12 & 8.30 & NA & 7.15 & 6.63 & $\mathbf{N A}$ \\
\hline 6.\% Dominant Taxon & $20 \%$ & $50 \%$ & $33 \%$ & $60 \%$ & $100 \%$ & NA & $53 \%$ & $27 \%$ & $\mathrm{NA}$ \\
\hline 7. Shredder / Total \# of Organisms Ratio & 0.10 & 0.25 & 0.33 & 0.00 & 0.00 & $\mathrm{NA}$ & 0.14 & 0.33 & $\mathrm{NA}$ \\
\hline 8. Density (organisms/m2) & 2728 & 11.11 & 16.67 & 27.78 & 5.56 & 2017ns & 17.78 & X & NA \\
\hline
\end{tabular}


Appendix Table B-7. Biological Parameter Results and Water Quality Ratings

Client: Westinghouse Savannah River Company

Stream: Four Mile Branch (Site 9)

County: Barnwell, SC

Collection Date: 5 Nov - 8 Dec 1997

\begin{tabular}{|c|c|c|c|c|c|c|c|c|c|}
\hline 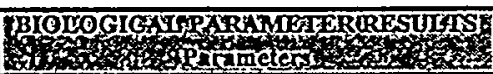 & Seps & Rep B & SRpo & Repin & Repis & Torat & Hexp & Kualititive & 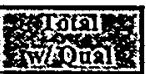 \\
\hline 1. Taxa Richness & 9 & 10 & 11 & 9 & 16 & 26 & 5.2 & 20 & 36 \\
\hline (Total Number of Organisms / Site) & 53 & 73 & 72 & 47. & 62 & 307 & 61.4 & 109 & 416 \\
\hline 2. EPT Index & 4.0 & 6.0 & 5.0 & 5.0 & 8.0 & $\mathbf{N A}$ & 5.6 & 6.0 & NA \\
\hline 3. EPT/Chironomid Ratio & 23.5 & 16.3 & 32.5 & 10.25 & 5.2857143 & NA & 17.6 & 5.8 & $\mathbf{N A}$ \\
\hline 4. Seraper / Filterer Ratio & 0.08 & 0.06 & 0.08 & 0.31 & 0.09 & $\mathbf{N A}$ & 0.12 & 1.90 & NA \\
\hline 5. Biotic Index & 6.80 & 6.35 & 6.45 & 6.31 & 6.08 & NA & 6.40 & 6.56 & NA \\
\hline 6.\% Dominant Taxon & $74 \%$ & $74 \%$ & $81 \%$ & $51 \%$ & $39 \%$ & NA & $64 \%$ & $23 \%$ & $\overline{\mathbf{N A}}$ \\
\hline 7. Shredder / Total \# of Organisms Ratio & 0.02 & 0.07 & 0.02 & 0.06 & 0.10 & NA & 0.05 & 0.17 & NA \\
\hline 8. Density (organisms/m2) & 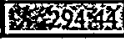 & 405.56 & 400.00 & 261.11 & 344.44 & 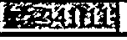 & 341.11 & Saris & $\mathrm{NA}$ \\
\hline
\end{tabular}




\section{Appendix Table B-7. Biological Parameter Results and Water Quality Ratings}

Client: Westinghouse Savannah River Company

Stream: Pen Branch (Site 10)

County: Barnwell, SC

Collection Date: 5 Nov - 8 Dec 1997

\begin{tabular}{|c|c|c|c|c|c|c|c|c|c|}
\hline 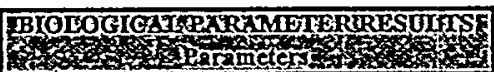 & Rep & (Repis & \% & SReping & 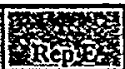 & Borming & 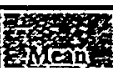 & ouatitive & arota \\
\hline 1. Taxa Richness & $\overline{6}$ & 7 & 3 & 5 & $\mathbf{6}$ & 10 & 2 & 34 & 38 \\
\hline (Total Number of Onganisms / Site) & 22 & 24 & 14 & 19 & 33 & 112 & $\overline{22.4}$ & 155 & 267 \\
\hline 2. EPT Index & 5.0 & 4.0 & 2.0 & 4.0 & 4.0 & NA & 3.8 & 9.0 & NA \\
\hline 3. EPT / Chironomid Ratio & 21.0 & 1.9 & 13.0 & 5.3 & 22 & $\mathbf{N A}$ & 8.7 & 0.5 & NA \\
\hline 4. Scraper / Fillerer Ratio & NA & 5.50 & NA & NA & NA & NA & 1.10 & 2.33 & NA \\
\hline 5. Biotic Index & 5.55 & 5.88 & 4.76 & 5.66 & 5.69 & NA & 5.51 & 6.10 & NA \\
\hline 6.\% Dominant Taxon & $73 \%$ & $33 \%$ & $57 \%$ & $42 \%$ & $55 \%$ & NA & $52 \%$ & $39 \%$ & NA \\
\hline 7. Shredder / Total \# of Organisms Ratio & 0.11 & 0.27 & 0.39 & 0.24 & 0.21 & NA & 0.25 & 0.36 & $\mathrm{NA}$ \\
\hline 8. Density (organisms/m2) & 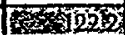 & 133.33 & 77.78 & 105.56 & 183.33 & 3242444 & $\overline{124.44}$ & 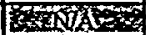 & $\overline{\text { NA }}$ \\
\hline
\end{tabular}




\section{Appendix Table B-7. Biological Parameter Results and Water Quality Ratings}

Client: Westinghouse Savannah River Company

Stream: Pen Branch (Site 11)

County: Barnwell, SC

Collection Date: 5 Nov - 8 Dec 1997

\begin{tabular}{|c|c|c|c|c|c|c|c|c|c|}
\hline 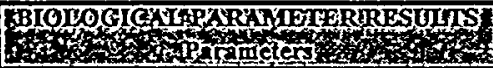 & Hed & 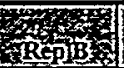 & Repo & Res & ineps & 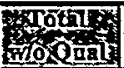 & 3 mon & ofuatitats & Trisla \\
\hline 1. Taxa Richness & 4 & 11 & 6 & 16 & 7 & 21 & 4.2 & 34 & 44 \\
\hline (Total Number of Organisms / Site) & 14 & 30 & 26 & 67 & 10 & 147 & 29.4 & 80 & 227 \\
\hline 2. EPT Index & 2.0 & 5.0 & 3.0 & 7.0 & 4.0 & NA & 4.2 & 7.0 & $\mathrm{NA}$ \\
\hline 3. EPT / Chironomid Ratio & NA & 2.6 & 23.0 & 5.3 & 2.33 & NA & 6.7 & 1.4 & $\mathbf{N A}$ \\
\hline 4. Seraper / Filterer Ratio & $\mathbf{N A}$ & 7.50 & $\mathbf{N A}$ & 0.48 & 1.50 & NA & 1.90 & 0.54 & NA \\
\hline 5. Biotic Index & 5.48 & 5.40 & 5.29 & 4.91 & 4.71 & NA & 5.16 & 6.07 & $\mathbf{N A}$ \\
\hline 6.\% Dominant Taxon & $79 \%$ & $47 \%$ & $69 \%$ & $25 \%$ & $30 \%$ & NA & $50 \%$ & $13 \%$ & NA \\
\hline 7. Shredder / Total \# of Onganisms Ratio & 0.07 & 0.18 & 0.19 & 0.22 & 0.35 & $\mathbf{N A}$ & 0.20 & 0.23 & $\mathbf{N A}$ \\
\hline 8. Density (organisms/m2) & 501208: & 166.67 & 144.44 & 372.22 & 55.56 & A8.6338 & 163.33 & Wras & NA \\
\hline
\end{tabular}




\section{Appendix Table B-7. Biological Parameter Results and Water Quality Ratings}

Client: Westinghouse Savannah River Company

Stream: Indian Grave Branch (Site 12)

County: Barnwell, SC

Collection Date: 5 Nov - 8 Dec 1997

\begin{tabular}{|c|c|c|c|c|c|c|c|c|c|}
\hline 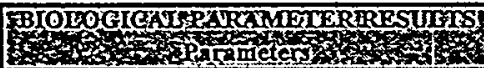 & $\sin \alpha$ & कos & thescis & Sepin & S & 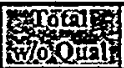 & sis & butaling & Thom \\
\hline 1. Taxa Richness & $\overrightarrow{5}$ & 3 & 12 & 8 & $\overline{5}$ & 23 & 4.6 & 25 & 38 \\
\hline (Total Number of Organisms / Site) & 9 & 15 & 39 & 16 & 12 & 91 & 18.2 & 78 & 169 \\
\hline 2. EPT Index & $\overline{1.0}$ & 0.0 & 2.0 & 2.0 & 2.0 & NA & 1.4 & 7.0 & NA \\
\hline 3. EPT / Chironomid Ratio & 0.8 & 0.0 & 0.5 & 0.56 & 2 & NA & 0.8 & 0.9 & NA \\
\hline 4. Scraper/ Filterer Ratio & NA & NA & 6.50 & 2.00 & $\mathbf{3 . 5 0}$ & NA & 2.40 & 0.94 & $\mathrm{NA}$ \\
\hline 5. Biotic Index & 6.54 & 6.81 & 6.34 & 6.67 & 6.52 & $\mathrm{NA}$ & 6.58 & 7.05 & $\mathbf{N A}$ \\
\hline 6.\% Dominant Taxoa & $33 \%$ & $80 \%$ & $31 \%$ & $38 \%$ & $58 \%$ & NA & $48 \%$ & 49\% & NA \\
\hline 7. Shredder / Total \# of Organisms Ratio & 0.22 & 0.40 & 0.19 & 0.22 & 0.13 & NA & 0.23 & 0.31 & NA \\
\hline 8. Density (organisms/m2) & 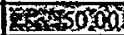 & 83.33 & 216.67 & 88.89 & 66.67 & 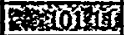 & 101.11 & 5oth & NA \\
\hline
\end{tabular}


Appendix Table B-7. Biological Parameter Results and Water Quality Ratings

Client: Westinghouse Savannah River Company

Stream: Pen Branch (Site 13)

County: Barnwell, SC

Collection Date: 5 Nov - 8 Dec 1997

\begin{tabular}{|c|c|c|c|c|c|c|c|c|c|}
\hline 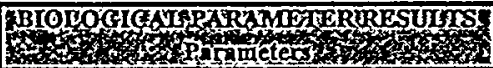 & 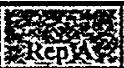 & ARepis & 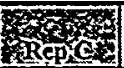 & Sepo & Rep & 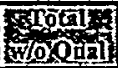 & 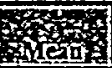 & 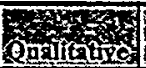 & Sother \\
\hline 1. Taxa Richness & 2 & 7 & 11 & 12 & 5 & 22 & 4.4 & 30 & 45 \\
\hline (Total Number of Orgariisms / Site) & 4 & 10 & 39 & 28 & $\overline{5}$ & 86 & 172 & 108 & 194 \\
\hline 2. EPT Index & 0.0 & 1.0 & 0.0 & 3.0 & 1.0 & $\mathbf{N A}$ & 1.0 & 7.0 & $\mathrm{NA}$ \\
\hline 3. EPT / Chironomid Ratio & 0.0 & 0.2 & 0.0 & 0.5294118 & 0.5 & NA & 0.2 & 0.3 & NA \\
\hline 4. Scraper / Filterer Ratio & NA & 1.25 & 0.00 & 0.58 & NA & $\mathbf{N A}$ & 0.37 & 0.36 & $\mathbf{N A}$ \\
\hline 5. Biotic Index & 7.28 & 6.95 & 6.72 & 5.93 & 5.82 & NA & 6.54 & 6.82 & NA \\
\hline 6. \% Dominant Taxon & $75 \%$ & $20 \%$ & $31 \%$ & $18 \%$ & $20 \%$ & NA & $33 \%$ & $26 \%$ & $\mathbf{N A}$ \\
\hline 7. Shredder / Total \# of Onganisms Ratio & 0.75 & 0.10 & 0.23 & 0.21 & 0.00 & NA & 0.26 & 0.22 & $\mathbf{N A}$ \\
\hline 8. Density (organisms/m2) & $5 \times 222$ & 55.56 & 216.67 & 155.56 & 27.78 & $5 \times 5556$ & 95.56 & Sind & $\mathbf{N A}$ \\
\hline
\end{tabular}




\section{Appendix Table B-7. Biological Parameter Results and Water Quality Ratings}

Client: Westinghouse Savannah River Company

Stream: Stecl Creek (Site 14)

County: Barnwell, SC

Collection Date: 5 Nov -8 Dec 1997

\begin{tabular}{|c|c|c|c|c|c|c|c|c|c|}
\hline 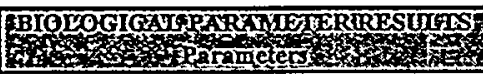 & Fing & 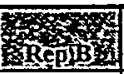 & Repsis & R.p. & 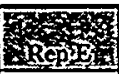 & Forar & $\Delta x_{n}$ & Qunditare & 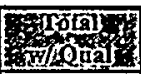 \\
\hline 1. Taxa Richness & 1 & 3 & 5 & 4 & 8 & 17 & 3.4 & 33 & 41 \\
\hline (Total Number of Organisms / Site) & 1 & 10 & 9 & 5 & 39 & 64 & 12.8 & 100 & 164 \\
\hline 2. EPT Index & 0.0 & 2.0 & 1.0 & 1.0 & 4.0 & NA & 1.6 & 6.0 & NA \\
\hline 3. EPT/ Chironomid Ratio & 0.0 & NA & 0.6 & 2 & 1.71 & NA & 0.9 & 0.9 & NA \\
\hline 4. Seraper / Filterer Ratio & NA & NA & NA & NA & 1.67 & NA & 0.33 & 0.36 & NA \\
\hline 5. Biotic Index & 7.60 & 6.03 & 5.59 & 6.02 & 3.83 & NA & 5.81 & 6.77 & NA \\
\hline 6.\% Dominant Taxon & $100 \%$ & $80 \%$ & $33 \%$ & $40 \%$ & $33 \%$ & NA & $57 \%$ & $14 \%$ & NA \\
\hline 7. Shredder / Total \# of Organisms Ratio & 0.00 & 0.00 & 0.11 & 0.00 & 0.47 & NA & 0.12 & 0.15 & NA \\
\hline 8. Density (onganisms/m2) & 6356 & 55.56 & 50.00 & 27.78 & 216.67 & Gisin & 71.11 & SIFA & NA \\
\hline
\end{tabular}




\section{Appendix Table B-7. Biological Parameter Results and Water Quality Ratings}

Client: Westinghouse Savannah River Company

Stream: Meycrs Branch (Site 15)

County: Barnwell, SC

Collection Date: 5 Nov - 8 Dec 1997

\begin{tabular}{|c|c|c|c|c|c|c|c|c|c|}
\hline 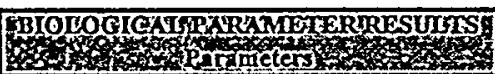 & SBCh & 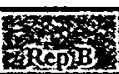 & 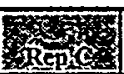 & SRepD & 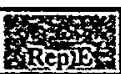 & सT: & \%og & ofolitive & 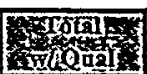 \\
\hline 1. Taxa Richness & 7 & 9 & 6 & 8 & 11 & 18 & 3.6 & 40 & 47 \\
\hline (Total Number of Organisms / Site) & 18 & 24 & 26 & 40 & 54 & 162 & 32.4 & 97 & 259 \\
\hline 2. EPT Index & 4.0 & 4.0 & 2.0 & 3.0 & 3.0 & NA & 3.2 & 17.0 & NA \\
\hline 3. EPT / Chironomid Ratio & 0.8 & 0.8 & 0.3 & 0.2121212 & 0.255814 & NA & 0.5 & 1.9 & $\overline{\mathrm{NA}}$ \\
\hline 4. Scraper / Fillerer Ratio & 0.63 & 0.75 & 2.00 & 0.83 & 0.17 & NA & 0.88 & 0.81 & NA \\
\hline 5. Biotic Index & 5.55 & 5.00 & 4.33 & 433 & 4.85 & NA & $\overline{4.81}$ & 5.68 & NA \\
\hline 6.\% Dominant Taxon & $28 \%$ & $25 \%$ & $35 \%$ & $43 \%$ & $28 \%$ & NA & $32 \%$ & 16\% & NA \\
\hline 7. Shredder / Total \# of Organisms Ratio & 0.06 & 0.29 & 0.25 & 0.25 & 0.21 & NA & 0.21 & 0.28 & NA \\
\hline 8. Density (organisms/m2) & Rexpoo & 133.33 & 144.44 & 222.22 & 300.00 & 818000 & 180.00 & 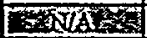 & $\mathbf{N A}$ \\
\hline
\end{tabular}




\section{Appendix Table B-7. Biological Parameter Results and Water Quality Ratings}

Client: Westinghouse Sayannah River Company

Stream: Four Mile (Site 16)

County: Barnwell, SC

Collection Date: 5 Nov - 8 Dec 1997

\begin{tabular}{|c|c|c|c|c|c|c|c|c|c|}
\hline 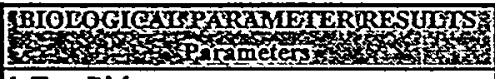 & Rept & SRepin & 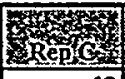 & 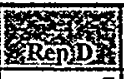 & 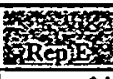 & 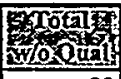 & 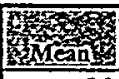 & 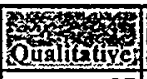 & 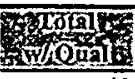 \\
\hline 1. Taxa Richness & 8 & 13 & 12 & 7 & 14 & 29 & 5.8 & 27 & 41 \\
\hline (Total Number of Organisms / Sitc) & 17 & 69 & 41 & 22 & 57 & 206 & 41.2 & 96. & 302 \\
\hline 2. EPT Index & 2.0 & 2.0 & 2.0 & 4.0 & 4.0 & NA & 2.8 & 6.0 & $\overline{\mathrm{NA}}$ \\
\hline 3. EPT / Chironomid Ratio & 2.3 & 0.5 & 0.4 & 2.67 & 0.33 & $\mathrm{NA}$ & 1.2 & 0.2 & NA \\
\hline 4. Scraper / Filterer Ratio & 1.38 & 1.90 & 0.45 & 1.20 & 0.25 & $\mathbf{N A}$ & 1.04 & 0.37 & $\overline{\mathbf{N A}}$ \\
\hline 5. Biotic Index & 6.06 & 5.72 & 6.45 & 5.42 & 6.09 & $\mathrm{NA}$ & 5.95 & 7.55 & NA \\
\hline 6.\% Dominant Taxon & $47 \%$ & $23 \%$ & $24 \%$ & $55 \%$ & $21 \%$ & NA & $34 \%$ & $27 \%$ & $\overline{\text { NA }}$ \\
\hline 7. Shredder / Total \# of Organisms Ratio & 0.06 & 0.04 & 0.07 & 0.07 & 0.02 & NA & 0.05 & 0.19 & NA \\
\hline 8. Density (organisms/m2) & 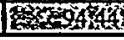 & 383.33 & 227.78 & 122.22 & 316.67 & x 22889 & 228.89 & 3 TA & NA \\
\hline
\end{tabular}




\section{APPENDIX C}

\section{FISH ASSEMBLAGE DATA}


Summary of fish assemblage data from Four Mile Creek near Rd. 4

\begin{tabular}{|c|c|c|c|c|c|}
\hline \multirow[b]{2}{*}{ Species } & & \multicolumn{3}{|c|}{ Replicate } & \multirow[b]{2}{*}{ Totals } \\
\hline & & $\bar{A}$ & $\mathrm{~B}$ & $\mathrm{C}$ & \\
\hline American eel & Anguilla rostrata & & & & \\
\hline banded pygmy sunfish & Elassoma zonatum & & & & \\
\hline blackbanded darter & Percina nigrofasciata & & & & - \\
\hline bluegill & Lepomis macrochirus & & & & \\
\hline bluehead chub & Nocomis leptocephalus & & & & \\
\hline bowfin & amia calva & & & & \\
\hline brook silverside & Labidesthes sicculus & & & & \\
\hline chain pickerel & esox niger & & & & \\
\hline coastal shiner & Notropis petersoni & & & & \\
\hline creek chub & Notropis atromaculatus & & & & \\
\hline creek chubsucker & Erimyzon & & 1 & 4 & 5 \\
\hline dollar sunfish & Lepomis marginatus & & 2 & 3 & 5 \\
\hline dusky shiner & Notropis cummingsae & & & & \\
\hline flat bullhead & Ameiurus platycephalus & & & & \\
\hline golden shiner & Notemigonus crysoleucas & & & & \\
\hline largemouth bass & Micropterus salmoides & & & & \\
\hline lined topminnow & Fundulus lineolatus & & & & \\
\hline longnose gar & Lepisosteus osseus & & & & \\
\hline margined madtom & Noturus insignis & & & & \\
\hline mosquitofish & Gambusia affinis & 7 & 2 & & 9 \\
\hline pirate perch & Aphredoderus sayanus & & 1 & 4 & 5 \\
\hline redbreast sunfish & Lepomis auritus & & 3 & 1 & 4 \\
\hline redfin pickerel & Esox americanus & & 1 & & 1 \\
\hline sailfin shiner & Pteronotropis hypselopterus & & & & \\
\hline Savannah darter & Etheostoma fricksium & & & & \\
\hline speckled madtom & Noturus leptacanthus & & & & \\
\hline spottail shiner & Notropis hudsonius & & & & \\
\hline spotted sucker & Minytrema melanops & & & & \\
\hline spotted sunfish & Lepomis punctatus & & & 1 & 1 \\
\hline striped bass & Morone saxatilis & & & & \\
\hline tadpole madtom & Noturus gyrinus & & & 1 & 1 \\
\hline tesselated darter & Etheostoma olmstedi & & & & \\
\hline warmouth & Lepomis gulosus & & & & \\
\hline yellow bullhead & Ameiurus natalis & & 2 & 1 & 3 \\
\hline yellow perch & Perca flavescens & & & & \\
\hline yellowfin shiner & Notropis lutipinnis & 2 & & & 2 \\
\hline
\end{tabular}


Summary of fish assemblage data from Four Mile Creek near Rd. C

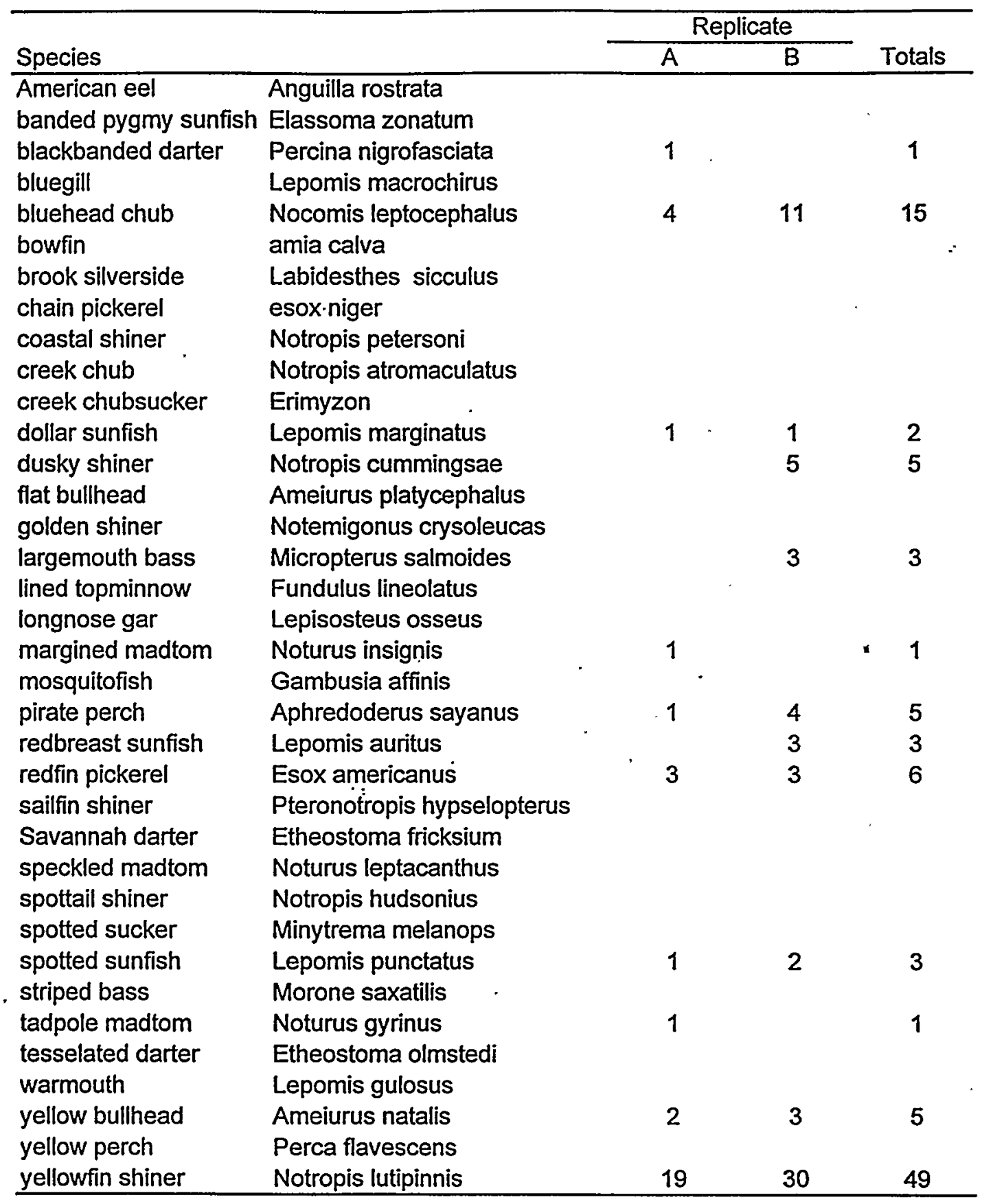


Summary of fish assemblage data from Four Mile Creek near Rd. A.7

\begin{tabular}{|c|c|c|c|c|c|}
\hline \multirow[b]{2}{*}{ Species } & & \multicolumn{3}{|c|}{ Replicate } & \multirow[b]{2}{*}{ Totals } \\
\hline & & A & $\mathrm{B}$ & $\mathrm{C}$ & \\
\hline $\begin{array}{l}\text { American eel } \\
\text { banded pvamy sunfis }\end{array}$ & $\begin{array}{l}\text { Anguilla rostrata } \\
\text { Flassoma }\end{array}$ & & & 2 & 2 \\
\hline $\begin{array}{l}\text { blackbanded darter } \\
\text { bluegill }\end{array}$ & $\begin{array}{l}\text { Percina nigrofasciata } \\
\text { Lepomis macrochirus }\end{array}$ & 1 & 4 & & 5 - \\
\hline $\begin{array}{l}\text { bluehead chub } \\
\text { bowfin }\end{array}$ & $\begin{array}{l}\text { Nocomis leptocephalus } \\
\text { amia calva }\end{array}$ & & 5 & 1 & 6 \\
\hline $\begin{array}{l}\text { brook silverside } \\
\text { chain pickerel }\end{array}$ & $\begin{array}{l}\text { Labidesthes sicculus } \\
\text { esox niger }\end{array}$ & & & & \\
\hline coastal shiner & Notropis petersoni & & & & \\
\hline creek chub & Notropis atromaculatus & & & & \\
\hline creek chubsucker & Erimyzon & & & & \\
\hline dollar sunfish & Lepomis marginatus & & & & \\
\hline dusky shiner & Notropis cummingsae & 1 & 1 & 35 & 37 \\
\hline flat bullhead & Ameiurus platycephalus & 3 & & & 3 \\
\hline golden shiner & Notemigonus crysoleucas & & & & \\
\hline largemouth bass & Micropterus salmoides & & & & \\
\hline lined topminnow & Fundulus lineolatus & & & & \\
\hline longnose gar & Lepisosteus osseus & & & & \\
\hline margined madtom & Noturus insigniș & & & & \\
\hline mosquitofish & Gambusia affinis & & & & \\
\hline pirate perch & Aphredoderus sayanus & 3 & 1 & 1 & 5 \\
\hline redbreast sunfish & Lepomis auritus & 4 & 1 & & 5 \\
\hline redfin pickerel & Esox americanus & & 3 & & 3 \\
\hline sailfin shiner & Pteronotropis hypselopterus & & 5 & & 5 \\
\hline Savannah darter & Etheostoma fricksium & & & & \\
\hline speckled madtom & Noturus leptacanthus & & & & \\
\hline spottail shiner & Notropis hudsonius & & & & \\
\hline spotted sucker & Minytrema melanops & 4 & & & 4 \\
\hline spotted sunfish & Lepomis punctatus & 1 & 4 & 5 & 10 \\
\hline striped bass & Morone saxatilis & & & & \\
\hline tadpole madtom & Noturus gyrinus & & & & \\
\hline $\begin{array}{l}\text { tesselated darter } \\
\text { warmouth }\end{array}$ & $\begin{array}{l}\text { Etheostoma olmstedi } \\
\text { Lepomis gulosus }\end{array}$ & 3 & 13 & & 16 \\
\hline yellow bullhead & Ameiurus natalis & & & 2 & 2 \\
\hline yellow perch & Perca flavescens & & & & \\
\hline yellowfin shiner & Notropis lutipinnis & 12 & 29 & 25 & 66 \\
\hline
\end{tabular}


Summary of fish assemblage data from Steel Creek near Rd. B

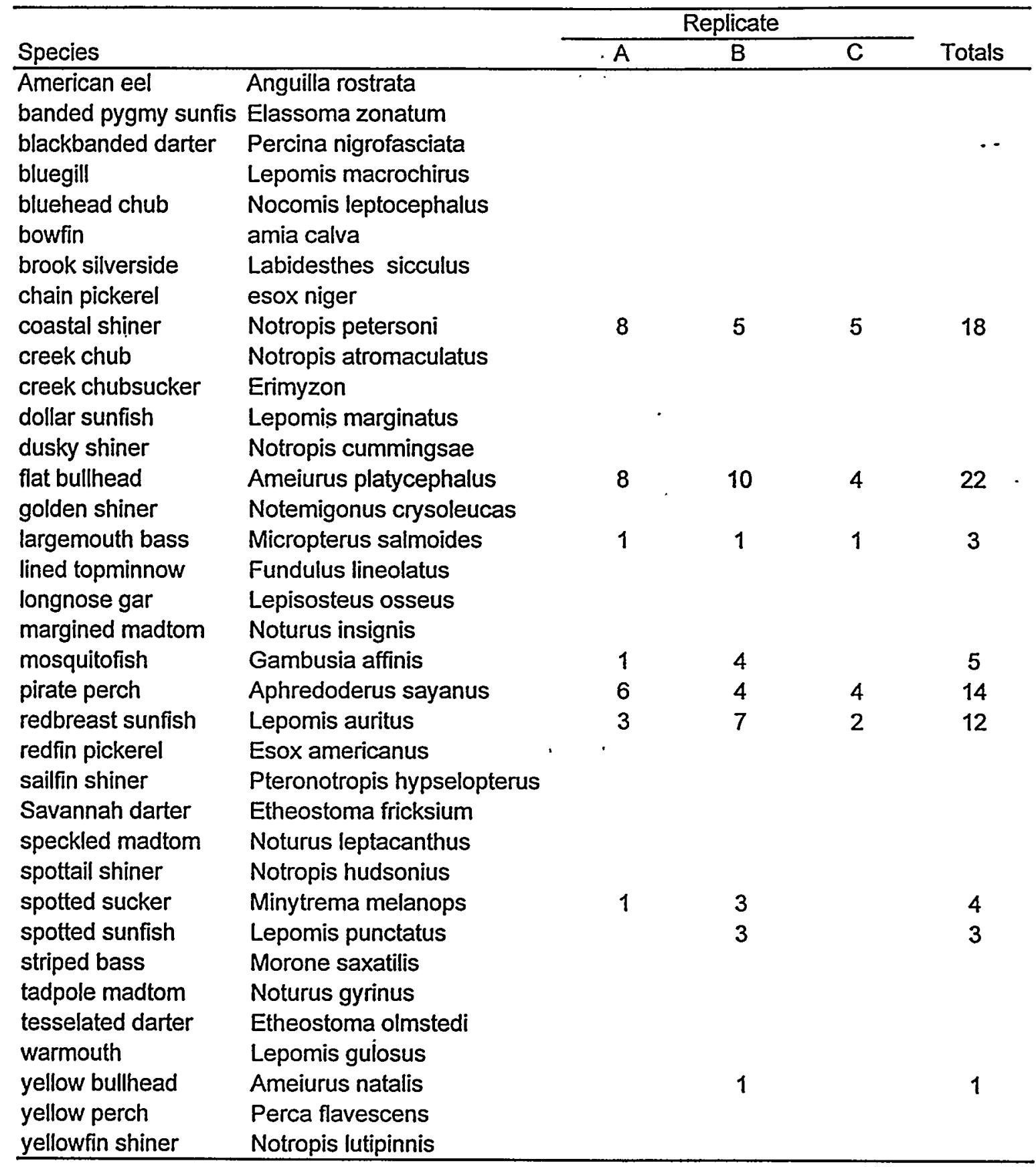


Summary of fish assemblage data from Four Mile Creek near Rd. A

\begin{tabular}{|c|c|c|c|c|c|}
\hline \multirow[b]{2}{*}{ Species } & & \multicolumn{3}{|c|}{ Replicate } & \multirow[b]{2}{*}{ Totals } \\
\hline & & $\bar{A}$ & $\mathrm{~B}$ & $\mathrm{C}$ & \\
\hline American eel & Anguilla rostrata & 6 & & 2 & 8 \\
\hline banded pygmy sunfish & Elassoma zonatum & & & & \\
\hline blackbanded darter & Percina nigrofasciata & 2 & 6 & 3 & $.1-1$ \\
\hline bluegill & Lepomis macrochirus & & & & \\
\hline bluehead chub & Nocomis leptocephalus & & 1 & & 1 \\
\hline bowfin & amia calva & & & & \\
\hline brook silverside & Labidesthes sicculus & & & & \\
\hline chain pickerel & esox niger & 1 & & & 1 \\
\hline coastal shiner & Notropis petersoni & & 1 & 3 & 4 \\
\hline creek chub & Notropis atromaculatus & & & & \\
\hline creek chubsucker & Erimyzon & & & 1 & 1 \\
\hline dollar sunfish & Lepomis marginatus & & 1 & & 1 \\
\hline dusky shiner & Notropis cummingsae & 1 & & 14 & 15 \\
\hline flat bullhead & Ameiurus platycephalus & 1 & 2 & & 3 \\
\hline golden shiner & Notemigonus crysoleucas & & & & \\
\hline largemouth bass & Micropterus salmoides & & 1 & & 1 \\
\hline lined topminnow & Fundulus lineolatus & & & & \\
\hline longnose gar & Lepisosteus osseus & & & & \\
\hline margined madtom & Noturus insignis & & & & \\
\hline mosquitofish & Gambusia affinis & & & & \\
\hline pirate perch & Aphredoderus sayanus & 1 & 1 & 1 & 3 \\
\hline redbreast sunfish & Lepomis auritus & 10 & 14 & 3 & 27 \\
\hline redfin pickerel & Esox americanus & 2 & & 1 & 3 \\
\hline sailfin shiner & Pteronotropis hypselopterus & & & & \\
\hline Savannah darter & Etheostoma fricksium & & 1 & & 1 \\
\hline speckled madtom & Noturus leptacanthus & 1 & 2 & & 3 \\
\hline spottail shiner & Notropis hudsonius & & & & \\
\hline spotted sucker & Minytrema melanops & 3 & & 1 & 4 \\
\hline spotted sunfish & Lepomis punctatus & 1 & 4 & 3 & 8 \\
\hline striped bass & Morone saxatilis & & & & \\
\hline tadpole madtom & Noturus gyrinus & & 2 & & 2 \\
\hline tesselated darter & Etheostoma olmstedi & & 4 & 4 & 8 \\
\hline warmouth & Lepomis gulosus & & & 1 & 1 \\
\hline yellow bullhead & Ameiurus natalis & 1 & 3 & & 4 \\
\hline yellow perch & Perca flavescens & & & & \\
\hline yellowfin shiner & Notropis lutipinnis & 5 & 15 & & 20 \\
\hline
\end{tabular}


Summary of fish assemblage data from Pen Branch near Rd. B

\begin{tabular}{|c|c|c|c|c|c|}
\hline \multirow{2}{*}{ Species } & & \multicolumn{3}{|c|}{ Replicate } & \multirow[b]{2}{*}{ Totals } \\
\hline & & $A$ & $\mathrm{~B}$ & $\mathrm{C}$ & \\
\hline $\begin{array}{l}\text { American eel } \\
\text { banded pyamy sunfi }\end{array}$ & $\begin{array}{l}\text { Anguilla rostrata } \\
\text { Elassoma zonatum }\end{array}$ & & & & \\
\hline blackbanded darter & Percina nigrofasciata & 2 & 2 & & $4 \ldots$ \\
\hline bluegill & Lepomis macrochirus & & & & \\
\hline bluehead chub & Nocomis leptocephalus & 1 & 2 & 2 & 5 \\
\hline bowfin & amia calva & & & & \\
\hline brook silverside & Labidesthes sicculus & & & & \\
\hline chain pickerel & esox niger & & & & \\
\hline coastal shiner & Notropis petersoni & & & & \\
\hline creek chub & Notropis atromaculatus & 4 & 2 & 1 & 7 \\
\hline creek chubsucker & Erimyzon & 1 & 1 & & 2 \\
\hline dollar sunfish & Lepomis marginatus & 2 & 2 & 1 & 5 \\
\hline dusky shiner & Notropis cummingsae & & & & \\
\hline flat bullhead & Ameiurus platycephalus & & & & \\
\hline golden shiner & Notemigonus crysoleucas & & . & & \\
\hline largemouth bass & Micropterus salmoides & & & & \\
\hline lined topminnow & Fundulus lineolatus & & & & \\
\hline longnose gar & Lepisosteus osseus & & & & \\
\hline margined madtom & Noturus insignis & & & & \\
\hline mosquitofish & Gambusia affinis & & & & \\
\hline pirate perch & Aphredoderus sayanus & 1 & 1 & 1 & 3 \\
\hline redbreast sunfish & Lepomis auritus & 1 & 3 & 4 & 8 \\
\hline redfin pickerel & Esox americanus & & 1 & 2 & 3 \\
\hline sailfin shiner & Pteronotropis hypselopterus & & & & \\
\hline Savannah darter & Etheostoma fricksium & & 1 & 1 & 2 \\
\hline speckled madtom & Noturus leptacanthus & & & 1 & 1 \\
\hline spottail shiner & Notropis hudsonius & & & & \\
\hline spotted sucker & Minytrema melanops & & & & \\
\hline spotted sunfish & Lepomis punctatus & 4 & 3 & 4 & 11 \\
\hline striped bass & Morone saxatilis & & & & \\
\hline tadpole madtom & Noturus gyrinus & & 1 & & 1 \\
\hline tesselated darter & Etheostoma olmstedi & 2 & 1 & 4 & 7 \\
\hline warmouth & Lepomis gulosus & & & & \\
\hline yellow bullhead & Ameiurus natalis & & 2 & & 2 \\
\hline yellow perch & Perca flavescens & & & & \\
\hline yellowfin shiner & Notropis lutipinnis & 33 & 30 & 25 & 88 \\
\hline
\end{tabular}


Summary of fish assemblage data from Pen Branch near Rd. C

\begin{tabular}{|c|c|c|c|c|c|c|}
\hline \multirow{2}{*}{ Species } & & \multicolumn{4}{|c|}{ Replicate } & \\
\hline & & A & B & C & & \\
\hline American eel & Anguilla rostrata & & 1 & 1 & 1 & $\overline{3}$ \\
\hline banded pygmy sunfish & Elassoma zonatum & & & & & \\
\hline blackbanded darter & Percina nigrofasciata & & & & & \\
\hline bluegill & Lepomis macrochirus & & & & & \\
\hline bluehead chub & Nocomis leptocephalus & & 3 & 13 & 14 & 30 \\
\hline bowfin & amia calva & & & & & \\
\hline brook silverside & Labidesthes sicculus & & & & & \\
\hline chain pickerel & esox niger & & & & & \\
\hline coastal shiner & Notropis petersoni & & & & & \\
\hline creek chub & Notropis atromaculatus & & & 3 & 1 & 4 \\
\hline creek chubsucker & Erimyzon & & 3 & & & 3 \\
\hline dollar sunfish & Lepomis marginatus & & & & & \\
\hline dusky shiner & Notropis cummingsae & & & & & \\
\hline flat bullhead & Ameiurus platycephalus & & & & & \\
\hline golden shiner & Notemigonus crysoleucas & & & & & \\
\hline largemouth bass & Micropterus salmoides & & & & & \\
\hline lined topminnow & Fundulus lineolatus & & & & & \\
\hline longnose gar & Lepisosteus osseus & & & & & \\
\hline margined madtom & Noturus insignis & & 1 & 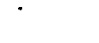 & & 1 \\
\hline mosquitofish & Gambusia affinis & & & & & \\
\hline pirate perch & Aphredoderus sayanus & & 15 & 4 & 8 & 27 \\
\hline redbreast sunfish & Lepomis auritus & & 4 & 2 & & 6 \\
\hline redfin pickerel & Esox americanus & & 3 & 2 & & 5 \\
\hline sailfin shiner & Pteronotropis hypselopterus & & & & & \\
\hline Savannah darter & Etheostoma fricksium & & & 1 & & 1 \\
\hline speckled madtom & Noturus leptacanthus & & & & & \\
\hline spottail shiner & Notropis hudsonius & & & & & \\
\hline spotted sucker & Minytrema melanops & & & & 1 & 1 \\
\hline spotted sunfish & Lepomis punctatus & & 7 & 3 & & 10 \\
\hline striped bass & Morone saxatilis & & & & & \\
\hline tadpole madtom & Noturus gyrinus & & & & 1 & 1 \\
\hline tesselated darter & Etheostoma olmstedi & & & & & \\
\hline warmouth & Lepomis gulosus & & & & 2 & 2 \\
\hline yellow bullhead & Ameiurus natalis & & 2 & & 3 & 5 \\
\hline yellow perch & Perca flavescens & & & & & \\
\hline yellowfin shiner & Notropis lutipinnis & & 26 & 26 & 38 & 90 \\
\hline
\end{tabular}


Summary of fish assemblage data from Mill Creek

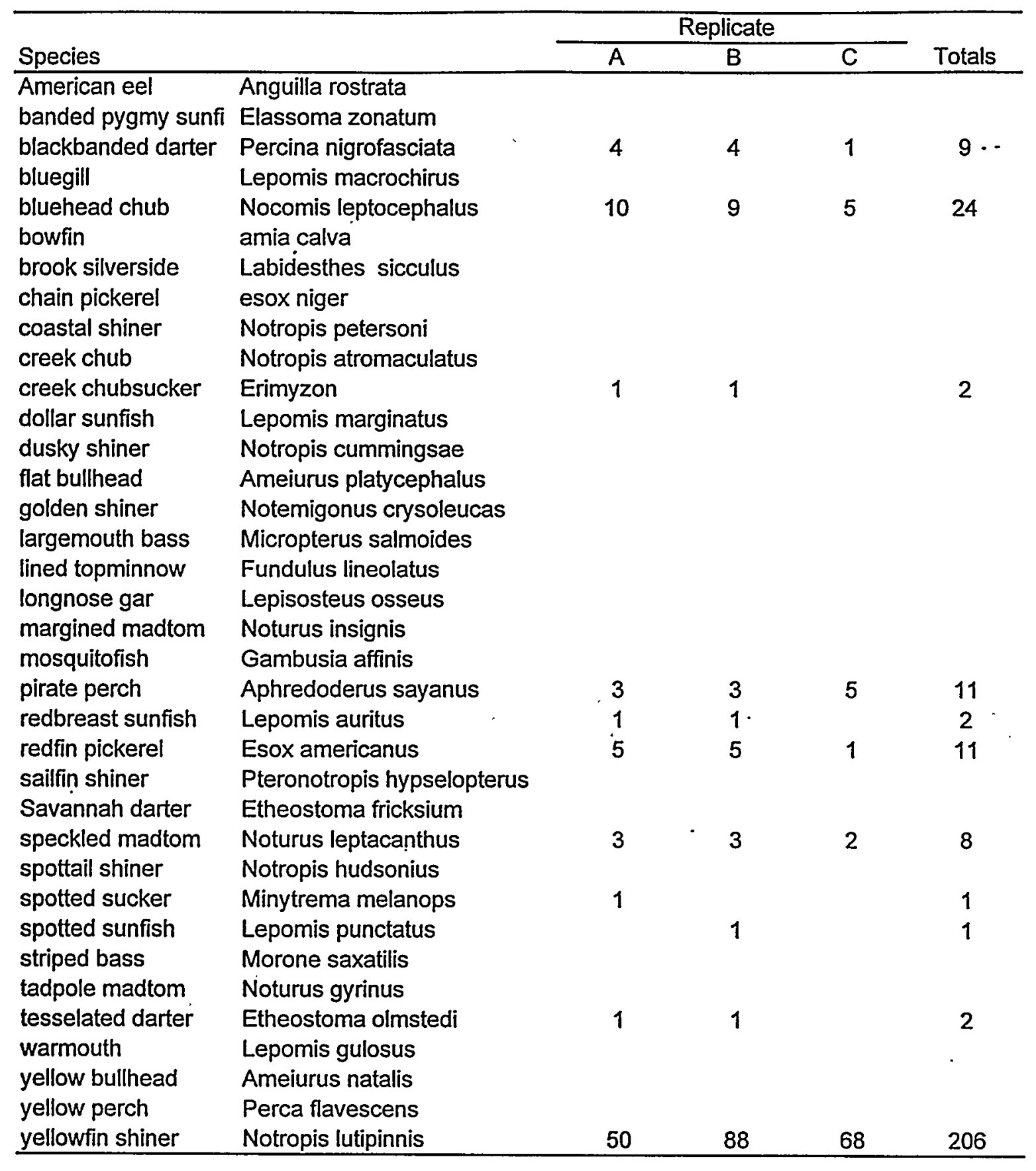


Summary of fish assemblage data from McQueen's Branch

\begin{tabular}{|c|c|c|c|c|c|}
\hline \multirow{2}{*}{ Species } & & \multicolumn{3}{|c|}{ Replicates } & \multirow[b]{2}{*}{ Totals } \\
\hline & & $\mathrm{A}$ & $\mathrm{B}$ & $\mathrm{C}$ & \\
\hline American eel & Anguilla rostrata & & 1 & & 1 \\
\hline banded pygmy sunfis & Elassoma zonatum & & & & \\
\hline blackbanded darter & Percina nigrofasciata & & & & $\cdots$ \\
\hline bluegill & Lepomis macrochirus & & & & \\
\hline $\begin{array}{l}\text { bluehead chub } \\
\text { bowfin }\end{array}$ & $\begin{array}{l}\text { Nocomis leptocephalus } \\
\text { amia calva }\end{array}$ & 27 & 18 & 7 & 52 \\
\hline brook silverside & Labidesthes sicculus & & & & \\
\hline chain pickerel & esox niger & & & & \\
\hline coastal shiner & Notropis petersoni & & & & \\
\hline creek chub & Notropis atromaculatus & 3 & 4 & 1 & 8 \\
\hline creek chubsucker & Erimyzon & & & & \\
\hline dollar sunfish & Lepomis marginatus & & & & \\
\hline dusky shiner & Notropis cummingsae & & & & \\
\hline flat bullhead & Ameiurus platycephalus & & & & \\
\hline golden shiner & Notemigonus crysoleucas & & & & \\
\hline largemouth bass & Micropterus salmoides & & & & \\
\hline lined topminnow & Fundulus lineolatus & & & & \\
\hline longnose gar & Lepisosteus osseus & & & & \\
\hline margined madtom & Noturus insignis & 2 & 1 & & 3 \\
\hline mosquitofish & Gambusia affinis & & & & \\
\hline pirate perch & Aphredoderus sayanus & 1 & 2 & & 3 \\
\hline redbreast sunfish & Lepomis auritus & & & & \\
\hline redfin pickerel & Esox americanus & 1 & & & 1 \\
\hline sailfin shiner & Pteronotropis hypselopterus & & & & \\
\hline Savannah darter & Etheostoma fricksium & & & & \\
\hline speckled madtom & Noturus leptacanthus & & & & \\
\hline spottail shiner & Notropis hudsonius & & & & \\
\hline spotted sucker & Minytrema melanops & & & & \\
\hline spotted sunfish & Lepomis punctatus & & & & \\
\hline striped bass & Morone saxatilis & & & & \\
\hline tadpole madtom & Noturus gyrinus & 1 & 1 & & 2 \\
\hline tesselated darter & Etheostoma olmstedi & 1 & & & 1 \\
\hline warmouth & Lepomis gulosus & & & & \\
\hline yellow bullhead & Ameiurus natalis & & & 1 & 1 \\
\hline yellow perch & Perca flavescens & & & & \\
\hline yellowfin shiner & Notropis lutipinnis & 40 & 27 & 9 & 76 \\
\hline
\end{tabular}


Summary of fish assemblage data from Tim's Branch

\begin{tabular}{|c|c|c|c|c|c|}
\hline \multirow{2}{*}{ Species } & & \multicolumn{3}{|c|}{ Replicates } & \multirow[b]{2}{*}{ Totals } \\
\hline & & $\bar{A}$ & $\mathrm{~B}$ & $\mathrm{C}$ & \\
\hline American eel & Anguilla rostrata & & & & \\
\hline banded pygmy sunfis & Elassoma zonatum & $\cdot$ & & & \\
\hline blackbanded darter & Percina nigrofasciata & & & & \\
\hline bluegill & Lepomis macrochirus & & & & \\
\hline bluehead chub & Nocomis leptocephalus & 8 & 7 & 5 & 20 \\
\hline bowfin & amia calva & & & 1 & 1 \\
\hline brook silverside & Labidesthes sicculus & & & & \\
\hline chain pickerel & esox niger & & & & \\
\hline coastal shiner & Notropis petersoni & & & & \\
\hline creek chub & Notropis atromaculatus & & & 3 & 3 \\
\hline creek chubsucker & Erimyzon & 3 & 8 & 13 & 24 \\
\hline dollar sunfish & Lepomis marginatus & 3 & 3 & 1 & 7 \\
\hline dusky shiner & Notropis cummingsae & & & & \\
\hline flat bullhead & Ameiurus platycephalus & & & & \\
\hline golden shiner & Notemigonus crysoleucas & 8 & 30 & 60 & 98 \\
\hline largemouth bass & Micropterus salmoides & & & & \\
\hline lined topminnow & Fundulus lineolatus & & & & \\
\hline longnose gar & Lepisosteus osseus & & & & \\
\hline margined madtom & Noturus insignis & & & & \\
\hline mosquitofish & Gambusia affinis & & 1 & 1 & 2 \\
\hline pirate perch & Aphredoderus sayanus & 6 & 10 & 15 & 31 \\
\hline redbreast sunfish & Lepomis auritus & 6 & 19 & 27 & 52 \\
\hline redfin pickerel & Esox americanus & 1 & 1 & 3 & 5 \\
\hline sailfin shiner & Pteronotropis hypselopterus & & & & \\
\hline Savannah darter & Etheostoma fricksium & & & & \\
\hline speckled madtom & Noturus leptacanthus & & & & \\
\hline spottail shiner & Notropis hudsonius & & & & \\
\hline spotted sucker & Minytrema melanops & & & & \\
\hline spotted sunfish & Lepomis punctatus & 2 & 1 & & 3 \\
\hline striped bass & Morone saxatilis & & & & \\
\hline tadpole madtom & Noturus gyrinus & & & & \\
\hline tesselated darter & Etheostoma olmstedi & & & & \\
\hline warmouth & Lepomis gulosus & 1 & 1 & 1 & 3 \\
\hline yellow bullhead & Ameiurus natalis & 12 & 9 & 20 & 41 \\
\hline yellow perch & Perca flavescens & & & & \\
\hline yellowfin shiner & Notropis lutipinnis & 15 & 11 & 23 & 49 \\
\hline
\end{tabular}


Summary of fish assemblage data from Pen Branch near Rd. A

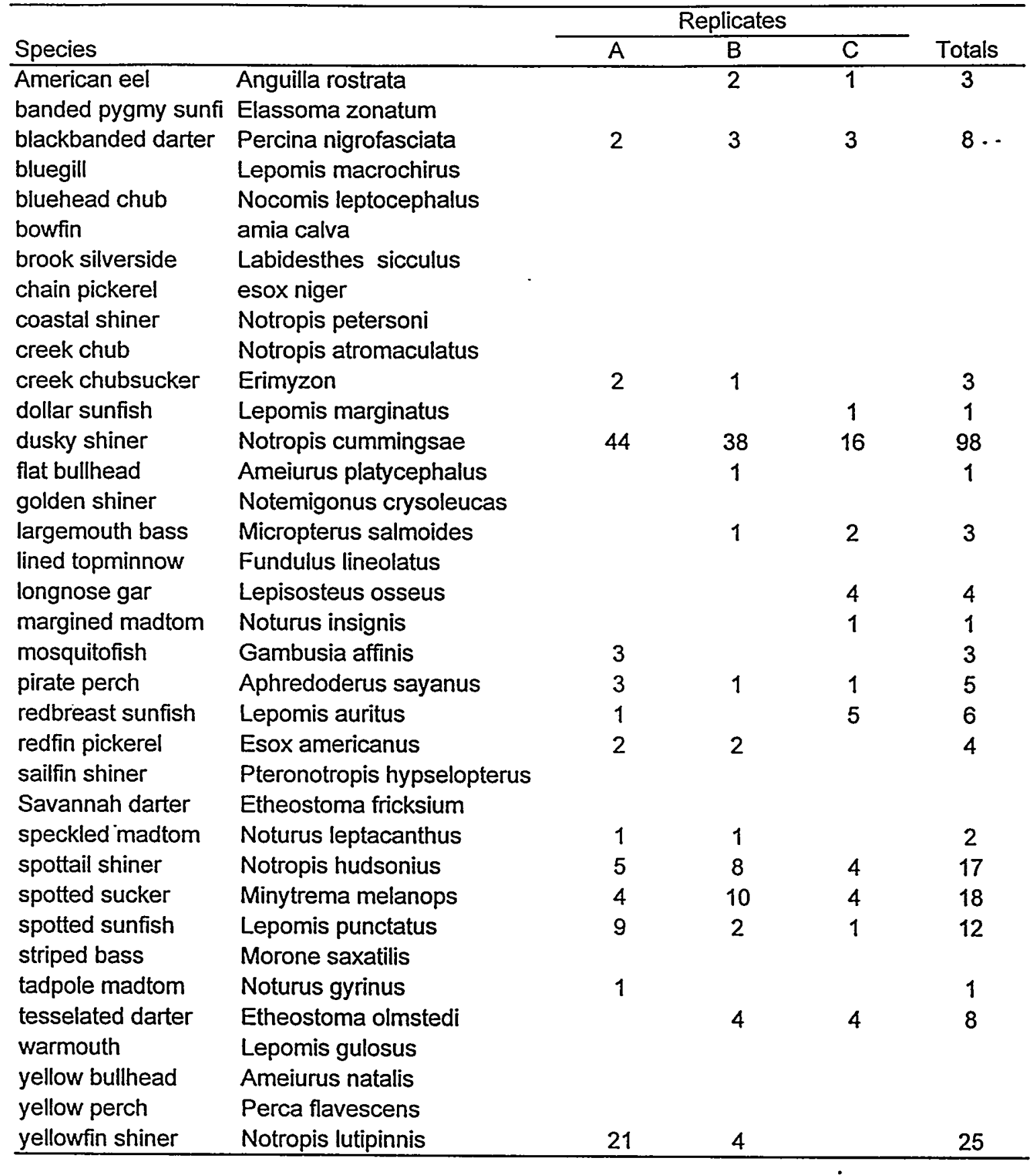


Summary of fish assemblage data from Indian Grave Branch

\begin{tabular}{|c|c|c|c|c|c|}
\hline \multirow[b]{2}{*}{ Species } & & \multicolumn{3}{|c|}{ Replicates } & \multirow[b]{2}{*}{ Totals } \\
\hline & & $\bar{A}$ & $\mathrm{~B}$ & $\mathrm{C}$ & \\
\hline $\begin{array}{l}\text { American eel } \\
\text { banded pygmy sunfi }\end{array}$ & $\begin{array}{l}\text { Anguilla rostrata } \\
\text { Elassoma zonatum }\end{array}$ & 1 & & & 1 \\
\hline $\begin{array}{l}\text { blackbanded darter } \\
\text { bluegill }\end{array}$ & $\begin{array}{l}\text { Percina nigrofasciata } \\
\text { Lepomis macrochirus }\end{array}$ & 16 & 42 & 26 & $84 \cdot-$ \\
\hline $\begin{array}{l}\text { bluehead chub } \\
\text { bowfin }\end{array}$ & $\begin{array}{l}\text { Nocomis leptocephalus } \\
\text { amia calva }\end{array}$ & & 1 & 3 & 4 \\
\hline $\begin{array}{l}\text { brook silverside } \\
\text { chain pickerel }\end{array}$ & $\begin{array}{l}\text { Labidesthes sicculus } \\
\text { esox niger }\end{array}$ & & & & \\
\hline coastal shiner & Notropis petersoni & & . & & \\
\hline creek chub & Notropis atromaculatus & & & & \\
\hline creek chubsucker & Erimyzon & & 1 & & 1 \\
\hline dollar sunfish & Lepomis marginatus & & 2 & & 2 \\
\hline dusky shiner & Notropis cummingsae & 13 & 7 & 11 & 31 \\
\hline flat bullhead & Ameiurus platycephalus & 1 & 6 & 24 & 31 \\
\hline golden shiner & Notemigonus crysoleucas & & & 1 & 1 \\
\hline largemouth bass & Micropterus salmoides & & 2 & & 2 \\
\hline lined topminnow & Fundulus lineolatus & & & & \\
\hline longnose gar & Lepisosteus osseus & · & 1 & 1 & 2 \\
\hline margined madtom & Noturus insignis & 2 & 4 & 10 & 16 \\
\hline mosquitofish & Gambusia affinis & 6 & 4 & 8 & 18 \\
\hline pirate perch & Aphredoderus sayanus & & 1 & & 1 \\
\hline redbreast sunfish & Lepomis auritus & 2 & 4 & 9 & 15 \\
\hline redfin pickerel & Esox americanus & & & & \\
\hline sailfin shiner & Pteronotropis hypselopterus & & & & \\
\hline Savannah darter & Etheostoma fricksium & & & & \\
\hline speckled madtom & Noturus leptacanthus & 1 & & 5 & 6 \\
\hline spottail shiner & Notropis hudsonius & 3 & 6 & 4 & 13 \\
\hline spotted sucker & Minytrema melanops & 7 & 4 & 3 & 14 \\
\hline spotted sunfish & Lepomis punctatus & 3 & 2 & 6 & 11 \\
\hline striped bass & Morone saxatilis & - & & & \\
\hline tadpole madtom & Noturus gyrinus & & & & \\
\hline tesselated darter & Etheostoma olmstedi & 1 & & & 1 \\
\hline warmouth & Lepomis gulosus & & & & \\
\hline yellow bullhead & Ameiurus natalis & & & & \\
\hline yellow perch & Perca flavescens & & & & \\
\hline yellowfin shiner & Notropis lutipinnis & 8 & 18 & 96 & 122 \\
\hline
\end{tabular}


Summary of fish assemblage data from Meyer's Branch

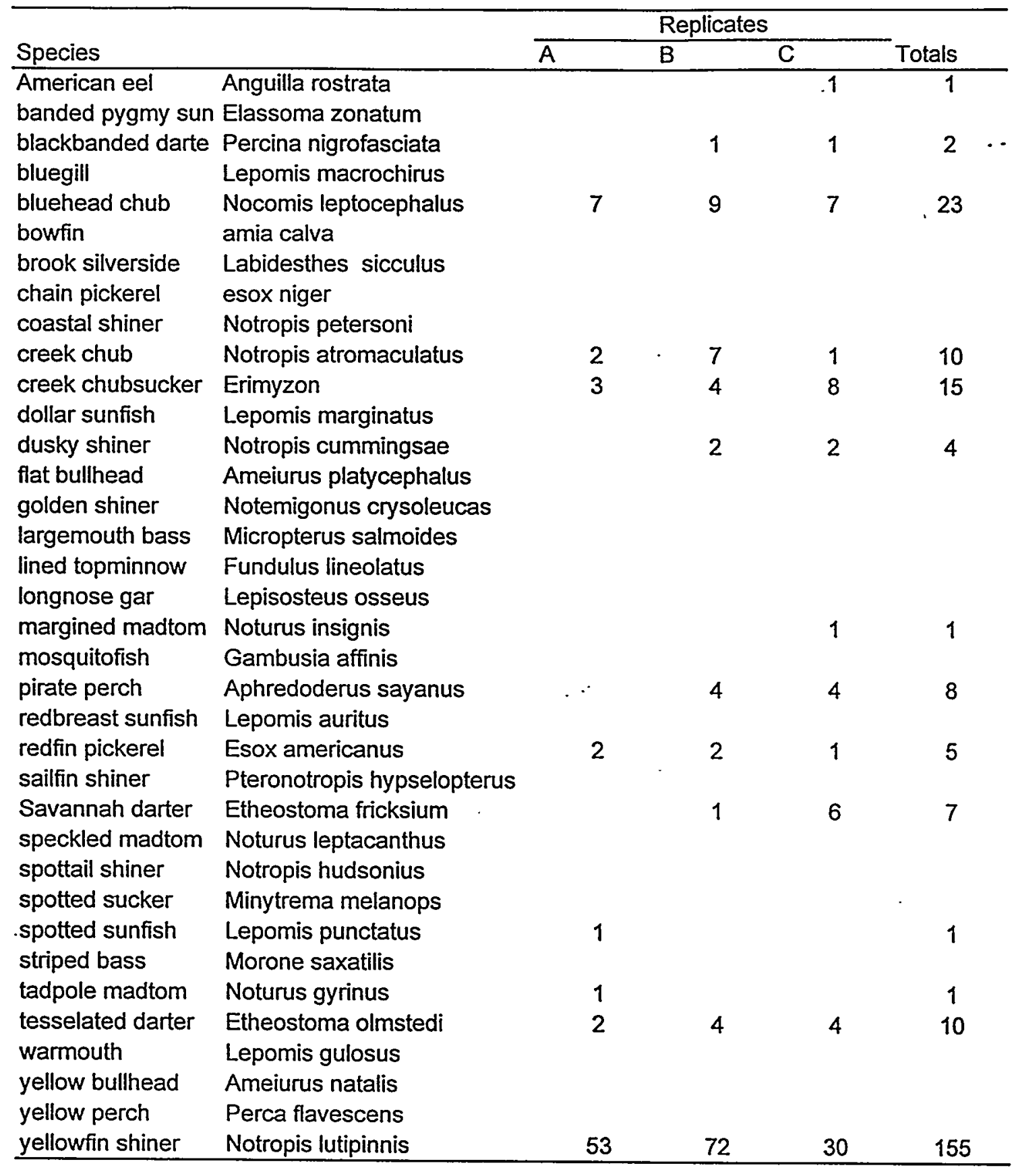


Summary of fish assemblage data from Crouch Branch

\begin{tabular}{|c|c|c|c|c|c|c|}
\hline \multirow{2}{*}{ Species } & & \multicolumn{4}{|c|}{ Replicates } & \multirow[b]{2}{*}{ Totals } \\
\hline & & $\bar{A}$ & $\mathrm{~B}$ & C & & \\
\hline American eel & Anguilla rostrata & & & & & \\
\hline banded pygmy sunfish & Elassoma zonatum & & 1 & & & 1 \\
\hline blackbanded darter & Percina nigrofasciata & & & & & . - \\
\hline bluegill & Lepomis macrochirus & & & & & \\
\hline bluehead chub & Nocomis leptocephalus & & & & 1 & 1 \\
\hline bowfin & amia calva & & . & & & \\
\hline brook silverside & Labidesthes sicculus & & & & & \\
\hline chain pickerel & esox niger & & & & & \\
\hline coastal shiner & Notropis petersoni & & & & & \\
\hline creek chub & Notropis atromaculatus & 5 & 4 & & 2 & 11 \\
\hline creek chubsucker & Erimyzon & & & & & \\
\hline dollar sunfish & Lepomis marginatus & & & & & \\
\hline dusky shiner & Notropis cummingsae & & & & & \\
\hline flat bullhead & Ameiurus platycephalus & & & & & \\
\hline golden shiner & Notemigonus crysoleucas & & & & & \\
\hline largemouth bass & Micropterus salmoides & & & & & \\
\hline lined topminnow & Fundulus lineolatus & & & & & \\
\hline longnose gar & Lepisosteus osseus & & & & & \\
\hline margined madtom & Noturus insignis & & & & & \\
\hline mosquitofish & Gambusia affinis & & & & & \\
\hline pirate perch & Aphredoderus sayanus & & & & & \\
\hline redbreast sunfish & Lepomis auritus & & & & & \\
\hline redfin pickerel & Esox americanus & & & & & \\
\hline sailfin shiner & Pteronotropis hypselopterus & & & & & \\
\hline Savannah darter & Etheostoma fricksium & & & & & \\
\hline speckled madtom & Noturus leptacanthus & & & & & \\
\hline spottail shiner & Notropis hudsonius & & & & & \\
\hline spotted sucker & Minytrema melanops & & & & & \\
\hline spotted sunfish & Lepomis punctatus & & & & & \\
\hline striped bass & Morone saxatilis & & & & & \\
\hline tadpole madtom & Noturus gyrinus & & & & & \\
\hline tesselated darter & Etheostoma olmstedi & & & & & \\
\hline warmouth & Lepomis gulosus & & & & & \\
\hline yellow bullhead & Ameiurus natalis & & & & & \\
\hline yellow perch & Perca flavescens & & & & & \\
\hline yellowfin shiner & Notropis lutipinnis & 2 & 3 & & & 5 \\
\hline
\end{tabular}


Summary of fish assemblage data from Upper Three Runs near Rd. A.2

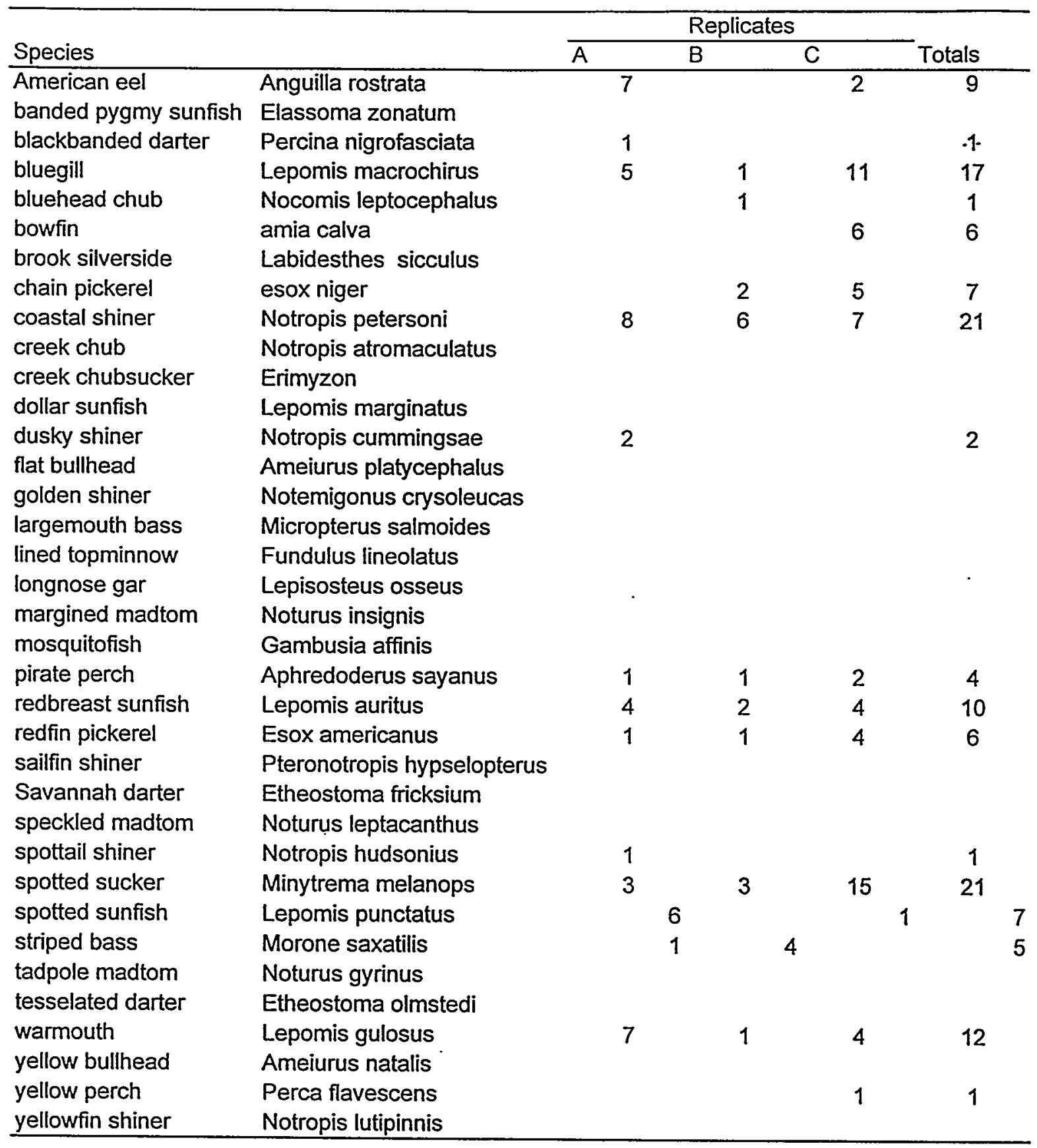


Summary of fish assemblage data from Upper Three Runs Tyler Bridge

\begin{tabular}{|c|c|c|c|c|c|}
\hline \multirow{2}{*}{ Species } & & \multicolumn{3}{|c|}{ Replicates } & \multirow[b]{2}{*}{ Totals } \\
\hline & & $\bar{A}$ & $B$ & $\mathrm{C}$ & \\
\hline $\begin{array}{l}\text { American eel } \\
\text { banded pygmy sunfish }\end{array}$ & $\begin{array}{l}\text { Anguilla rostrata } \\
\text { Elassoma zonatum }\end{array}$ & 3 & & 1 & 4 \\
\hline blackbanded darter & Percina nigrofasciata & & & 1 & 1. \\
\hline bluegill & Lepomis macrochirus & 1 & & 1 & 2 \\
\hline $\begin{array}{l}\text { bluehead chub } \\
\text { bowfin }\end{array}$ & $\begin{array}{l}\text { Nocomis leptocephalus } \\
\text { amia calva }\end{array}$ & & & & \\
\hline brook silverside & Labidesthes sicculus & 1 & & & 1 \\
\hline chain pickerel & esox niger & & 1 & & 1 \\
\hline coastal shiner & Notropis petersoni & & . & & \\
\hline creek chub & Notropis atromaculatus & & & & \\
\hline creek chubsucker & Erimyzon & & & & \\
\hline dollar sunfish & Lepomis marginatus & & & & \\
\hline dusky shiner & Notropis cummingsae & 31 & 4 & 14 & 49 \\
\hline flat bullhead & Ameiurus platycephalus & & & & \\
\hline golden shiner & Notemigonus crysoleucas & & & & \\
\hline largemouth bass & Micropterus salmoides & 1 & 2 & & 3 \\
\hline lined topminnow & Fundulus lineolatus & 1 & & & 1 \\
\hline longnose gar & Lepisosteus osseus & & & & \\
\hline margined madtom & Noturus insignis & & & & \\
\hline mosquitofish & Gambusia affinis & & & & \\
\hline pirate perch & Aphredoderus sayanus & & 1 & & 1 \\
\hline redbreast sunfish & Lepomis auritus & 1 & & & 1 \\
\hline redfin pickerel & Esox americanus & . & & & \\
\hline sailfin shiner & Pteronotropis hypselopterus & & 6 & 25 & 31 \\
\hline Savannah darter & Etheostoma fricksium & & & & \\
\hline speckled madtom & Noturus leptacanthus & & & & \\
\hline spottail shiner & Notropis hudsonius & & & & \\
\hline spotted sucker & Minytrema melanops & 5 & & 1 & 6 \\
\hline spotted sunfish & Lepomis punctatus & & & & \\
\hline striped bass & Morone saxatilis & & & & \\
\hline tadpole madtom & Noturus gyrinus & & & & \\
\hline tesselated darter & Etheostoma olmstedi & & & & \\
\hline warmouth & Lepomis gulosus & & & & \\
\hline yellow bullhead & Ameiurus natalis & & & & \\
\hline yellow perch & Perca flavescens & & 1 & & 1 \\
\hline yellowfin shiner & Notropis lutipinnis & & 12 & 16 & 28 \\
\hline
\end{tabular}

